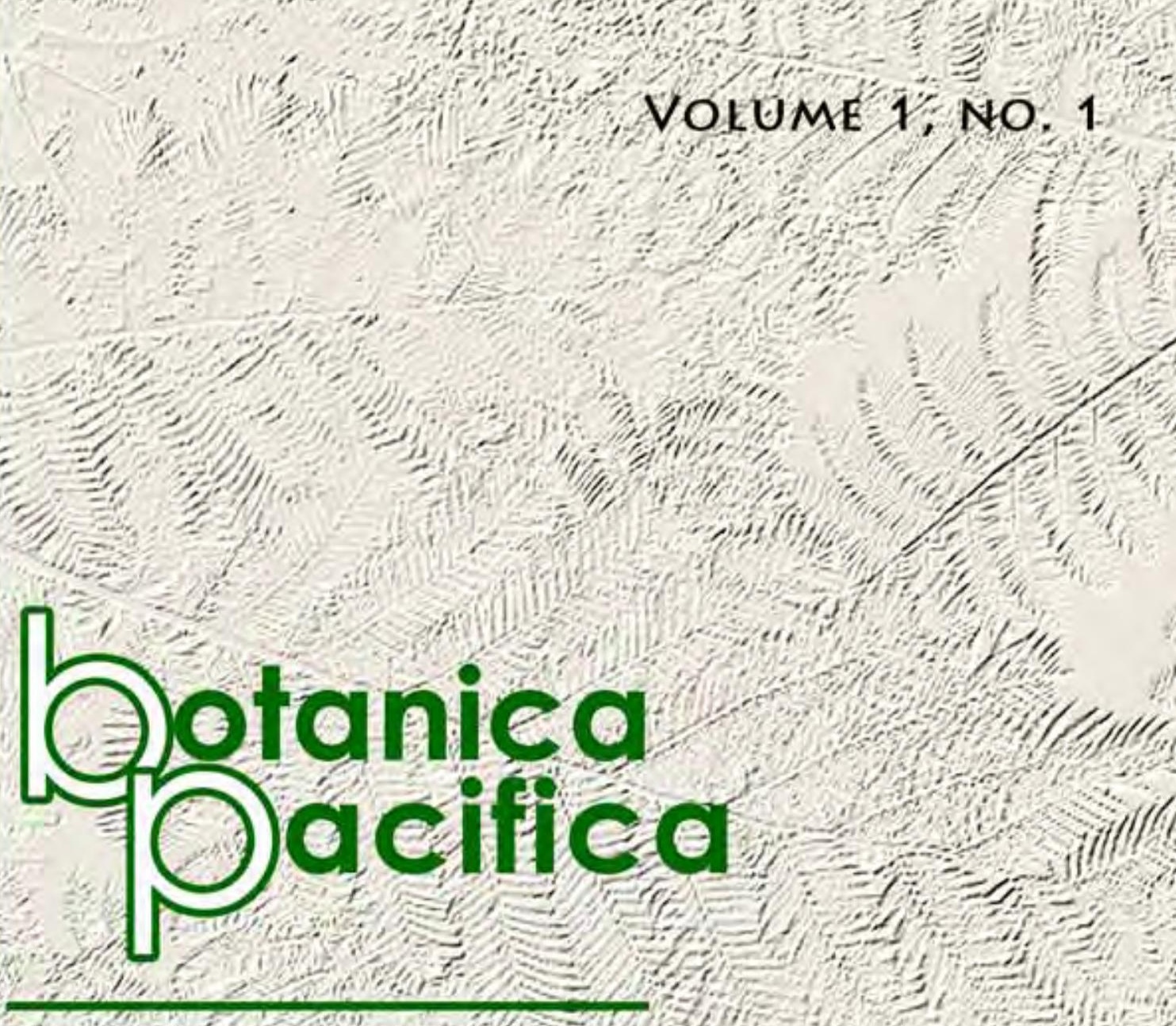

A journal of plant SCIENCE AND CONSERVATION

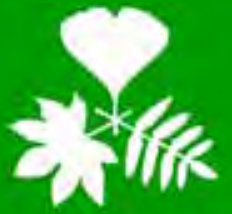

BOTANICAL GARDEN-INSTITUTE FEB RAS

*

INSTITUTE OF BIOLOGY AND

SOIL SCIENCE FEB RAS

WWW.CEOBOTANICA.RU/BP

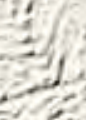

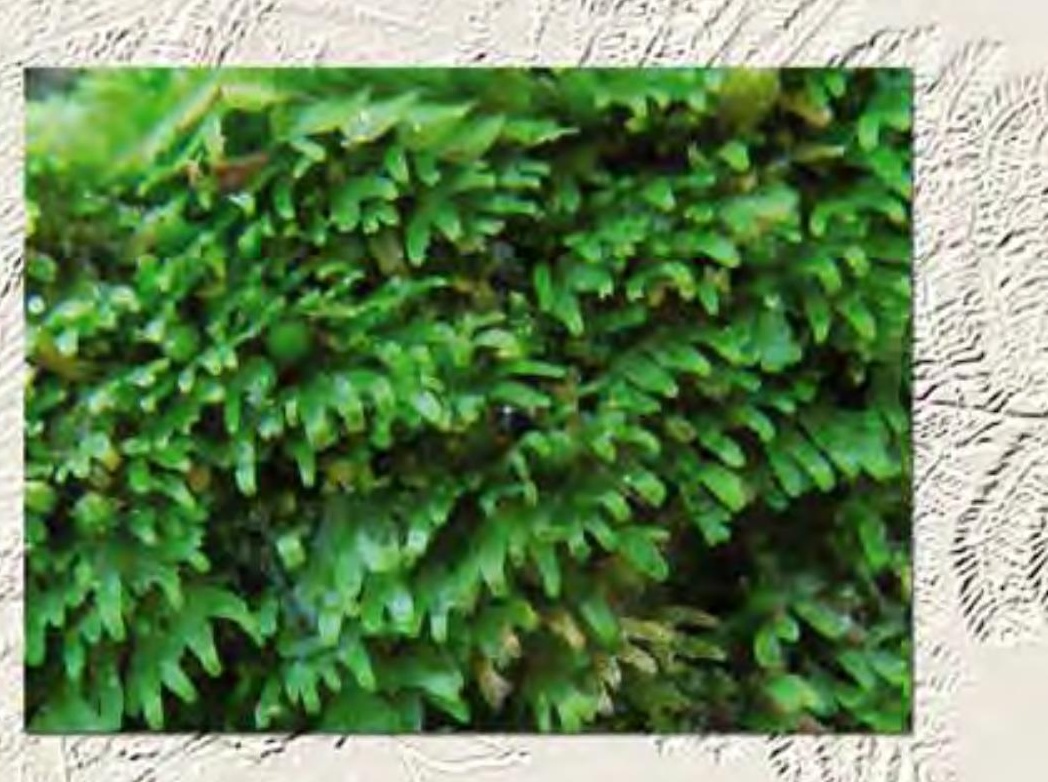




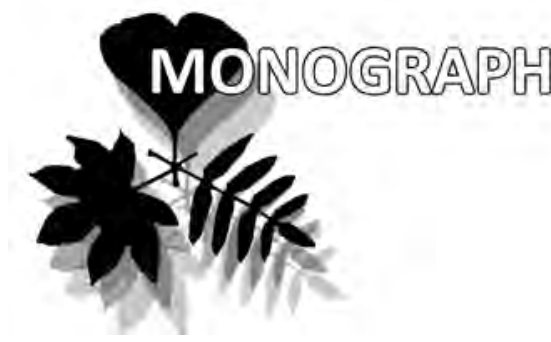

Seung Se Choi

Faculty of Life Sciences

Chonbuk National University

Jeonju, Jeonbuk Province, South Korea

E-mail: hepaticae@jbnu.ac.kr

Byung-Yun Sun

Same institution

E-mail: sunby@jbnu.ac.kr

Vadim A. Bakalin

2 Botanical Garden-Institute FEB RAS

Vladivostok, 690024, Russia

${ }^{3}$ Institute of Biology and Soil Science FEB RAS

Vladivostok, 690022, Russia

Email: v_bak@list.ru

* Corresponding author

Manuscript received: 02.04.2012

Review completed: 24.05.2012

Accepted for publication: 15.07.2012

\section{Scapania and Macrodiplophyllum in the Russian Far East}

\author{
Seung Se Chol ${ }^{1}$, Vadim A. BaKalin ${ }^{2} 3^{*}$ \& Byung-Yun Sun ${ }^{1}$
}

\begin{abstract}
A B S T R A C T
The genera Scapania and Macrodiplophyllum have been studied in the Russian Far East. Macrodiplophyllum is represented by three species that are known in this genus. Scapania includes 38 species that are distributed among 12 sections. Keys are provided for all taxa found in the Russian Far East. All species based on the Far Eastern material are illustrated. Some corrections have been made in respect to the infrageneric structure of Scapania. Specifically, section Brevicaules R. M. Schust. was united with section Apiculatae $\mathrm{H}$. Buch, S. sphaerifera $\mathrm{H}$. Buch was transferred to section Aequilobae Müll. Frib., and accordingly, section Spheriferae Konstant. \& Potemkin was synonymized with the latter. The understanding of the distributions of some species has been improved. S. parvidens Steph. was reevaluated at the species level. S. integerrima Steph., S. ligulata Steph. and S. ampliata Steph. are now excluded from the hepatic flora of Russia. Scapania magadanica S. S. Choi, Bakalin \& B.-Y. Sun sp. nov. is described based on the combination of paroicous inflorescence, green to colorless two-celled gemmae, a rounded apex of the dorsal lobe, and a non-decurrent ventral lobe, all of which are not present in other taxa of the genus.
\end{abstract}

Keywords:

Scapania, Macrodiplophyllum, Russian Far East, Scapaniaceae, taxonomy, Hepaticae

\begin{abstract}
Чои С.С., Бакалин В.А., Сан Б.-Ю. Scapania и Macrodiplophyllum на российском Аальнем Востоке

Проведена обработка родов Scapania и Macrodiplophyllum Аля российского Аальнего Востока. Macrodiplophyllum представлен 3 виАами, охватывающими все разнообразие рода. Scapania включает 38 вилов, объединенных в 12

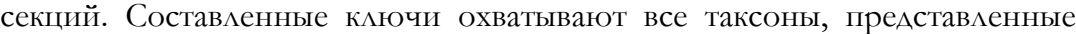
на российском Аальнем Востоке. А^я виАов, изученных по АаАьневосточным материалам, составлены оригинальные ил^юстрации. Внутриродовая структура рода Scapania подверглась некоторой переработке. Секция Brevicaules R. M Schust. объединена с секцией Apiculatae H. Buch, S. sphaerifera H. Buch перенесена в секцию Aequilobae Müll. Frib. и, таким образом, секция Spheriferae Konstant. \& Potemkin была сведена в синонимы с послелней. Рacпространение большинства таксонов было существенно уточнено. Восстановцен видовой ранг Scapania parvidens Steph. S. integerrima Steph., S. ligulata Steph. и $S$. ampliata Steph. исключены из флоры печеночников российского Аальнего Востока. Scapania magadanica S. S. Choi, Bakalin \& B.-Y. Sun sp. nov. описана на основе пареции, зеленых до бесцветных выводковых почек, закругленной верхушки дорзальной мопасти и не сбегающей вентральной мопасти, - комбинации, ранее неизвестной внутри рода Scapania.
\end{abstract}

ключевые слова:

Scapania, Macrodiplophyllhm, российский Аальний Восток, Scapaniaceae, таксономия, Нераticae

\section{NTRODUCTION}

The Russian Far East covers more than 3 millions $\mathrm{km}^{2}$, lying between $42^{\circ} \mathrm{N}$ and $71^{\circ} \mathrm{N}$, and is characterized by noticeable diversity in floristic composition, orography, and climate. Scapania and Macrodiplophyllum, as well as the more remotely related Diplophyllum, are called "scapanioid" genera, which are taxonomically diverse in the Russian Far East. This group was previously circumscribed as the oligogeneric family Scapaniaceae s. str. (e.g., Schuster 1974, Schljakov 1981), which has since been considerably enlarged when many former members of the Lophoziaceae were included (e.g. Vilnet et al. 2010). It is represented by two strongly phytogeographically detached clades: 1) Scapania and Macrodiplophyllum, which are taxonomically diverse in northern latitudes, including Arctic and Subarctic Asia and North America, with noticeable diversity in East Asia and the Himalayas, 2) and Diplophyllum, which is diverse in the tropics, descending into the Antipodes. Scapania and Macrodiplophyllum include 41 species (38 and 3, respectively) in Far Eastern Russia, and represent approximately 12\% of the total known hepatic taxonomic diversity in this area. Only five species of Diplophyllum are found in the Russian Far East, and with the exception of D. taxifolium (Wahlenb.) Dumort., which is common throughout in mountainous areas, are sporadically distributed. We restricted the present study to examining Macrodiplophyllum (including all three of the globally recognized species) and Scapania. 
Taxonomy of the genus Scapania is controversial. For example, some authors (Potemkin 1999, 2002) include Macrodiplophyllum in this genus, whereas others (Buch 1928) divide Scapania s. str. into two genera and treat the subgenus Scapaniella as a separate genus. Currently, Scapania and Macrodiplophyllum are accepted by the majority of bryologists (Konstantinova et al. 2009, Crandall-Stotler et al. 2009, Heinrichs et al. 2012) at the generic level. Thirty eight species from our study area were placed into 12 sections.

In total, 67 species were reported from eastern extratropical Asia due to their appearances in floristic papers (Piippo 1990, Hong 2003, Yamada \& Iwatsuki 2006, Yamada \& Choi 2007, Zuo \& Cao 2007a, Bakalin 2010), and approximately 30 of these were described from this area (Stephani 1910, Horikawa 1934, Amakawa \& Hattori 1953, 1954, 1955, Potemkin 2000, 2001, Zuo et al. 2007b, 2007c). For this variable and diverse territory, some regional treatments, such as the treatment of Japanese Scapaniaceae (Amakawa \& Hattori 1953, 1954, 1955), which is somewhat outdated, as well as some attempts to describe the Chinese Scapania (Potemkin 2000, 2001, Zuo \& Cao 2007a, Zuo et al. 2007b, 2007c) were published. Scapania and Macrodiplophyllum were never examined specifically for the Russian Far East, but books such as those by Schljakov (1981) and Buch (1928) include very valuable information on the distribution and taxonomy of these genera in the Russian Far East, as these authors examined approximately $85 \%$ of the present species diversity within the area. Bakalin (2004) has recently reviewed Macrodiplophyllum for Russia and published the most recent information on the distribution of Scapania and Macrodiplophyllum in this area (Bakalin 2009, 2010). He has reported 43 species from the Russian Far East (three of which were excluded and one was added in the present paper), a number representing more than half of the East Asian diversity of that group, and including both Arctic taxa (e.g., S. simmonsii, S. spitsbergensis) and East Asian ones (sect. Stephania).

The present account is largely based on a critical revision of 425 specimens that are kept at the Botanical Garden-Institute, Vladivostok [VBGI; collection made mostly by Bakalin, was transferred from the Institute of Biology and Soil Science (VLA)], as well as materials from the Herbarium of the Polar-Alpine Botanical GardenInstitute [KPABG; various collectors, but mostly Bakalin]. Together, these herbaria include majority of all specimens of considered genera ever gathered in the Russian Far East. Unfortunately, there were no possibility to study most specimens from Chukotka preserved in LE. Descriptions are based exclusively on the study of material from this area and include morphological features presented in the studied material (e.g., perianths, androecia, gemmae). Only the descriptions of four species ( $S$. ligulifolia, $S$. praetervisa, $S$. verrucosa, $S$. zemliae) were based on material from other regions. The latter taxa were reported from our area but vouchers were not studied (see specimens examined). For morphological details not presented in studied specimens we provide in most cases data from literature (with corresponding reference).

\section{Key to scapanioid genera of the Russian Far East}

1. Perianth usually strongly flattened, truncate, lacking plicae; gemmae usually elliptical to spherical, smooth; keel usually sharp and acute throughout ....................................................................... Scapania.

1. Perianth usually weakly flattened, contracted, plicate; gemmae usually angular to stellate, rarely elliptical (Scapania sect. Kaalaasia); keel usually obtuse or leaves are canaliculate; leaf base commonly sheathing ............................................................................. 2 .

2. Leaves evidently spreading from the base; gemmae elliptical ....... ………………………………………... Scapania sect. Kaalaasia.

2. Leaves with sheathing base; gemmae usually angular, stellate ...

3. Plants larger $2.5-4.5 \mathrm{~mm}$ wide, robust; gemmae 2-4 celled; trigones usually convex ......................................... Macrodiplophyllum.

3. Plants smaller 1.0-3.5 mm wide, not robust; gemmae 1-2 celled; trigones usually concave .................. Diplophyllum [not treated here].

SCAPANIA (Dumort.) Dumort. Recueil Observ. Jungerm. 14, 1835 nom. cons.

Martinellius Bennet \& Gray, ex S. F. Gray, Nat. Arr. Brit. Pl. I: 691, 1821.

Description: Plants $6.0-150.0 \times 0.5-35.0^{1} \mathrm{~mm}$, prostrate to ascending and erect, from yellowish green to brown and purplish to red-purple. Stems sparsely branched, dorsal surface yellowish green to greenish pale brown, ventral surface not differs from dorsal one to deep reddish brown and fuscous brown, in cross section rounded to transversely elliptic, with thick-walled cortex cells in 1-3(-5) layers. Rhizoids sparse to numerous, isolate to fasciculate and spreading at right angle from the stem, colorless to pale brown. Leaves unequally bilobed, usually conduplicate, contiguous to imbricate, rarely canaliculate; keel (0.1-)0.2-0.7(-0.8) of ventral lobe length ${ }^{2}$; dorsal lobe transversely inserted, not or distinctly decurrent, obliquely ovate to lanceolate or rounded-quadrate, $0.5-1.0$ of ventral lobe size; ventral lobe transversely inserted, insertion line obscurely to distinctly arched, not or distinctly decurrent, obliquely oblong to obovate or rounded, margin in both lobes entire to denticulate or ciliate, with acute to obtuse or rounded apex. Cells mostly with distinct trigones, thinto thick-walled, cuticle almost smooth or weakly strilolate to verrucose or coarsely papillose. Oil bodies (1)2-8(12) per cells, spherical to elliptical or ovate, usually granulate. Specialized asexual reproduction by 1-2(4)-celled, green to reddish or deep brown and purple gemmae, usually elliptical. Sexual condition (usually) dioicous to (rarely) paroicous. Androecia intercalary, 1-4-androus, antheridial stalk 1-seriate. Gynoecia terminal on leading axis, bracts in one pair. Perianth oblong to obovate, truncate, mostly dorsiventrally compressed to almost cylindrical, smooth to weakly plicate; perigynium absent. Capsule oblong-ovate, walls 4-6-stratose, exterior wall with nodular thickenings, interior wall with annular thickenings, brown. Elaters 2-spiral, brown. Spores spherical, papillose, dark-brownish ${ }^{3}$.

\footnotetext{
${ }^{1}$ In any complex numerals we indicate length and then width

${ }^{2}$ The system of lobe measurements follows Buch (1928)

3 Morphological descriptions are exclusively based on studied specimens, but in some cases we provide morphological details taken from literature in square brackets with corresponding reference
} 
Species ca. 100 (38 in the flora): Eurasia, North America, Central America, South America, Africa, Australia and Oceania, Antarctica.

\section{Key of sections of Scapania}

1. Ventral lobe not decurrent or slightly decurrent . .2.

2. Leaf lobes subequal, dorsal lobe $0.75-0.85$ the size of ventral lobe; paroicous ........................................................ sect. 7. Compactae. 2. Leaf lobes unequal, dorsal lobe $0.35-0.80$ the size of ventral

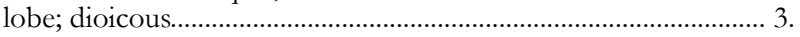
3. Ventral lobe narrowly ovate to obovate and lingulate, $0.45-0.85$

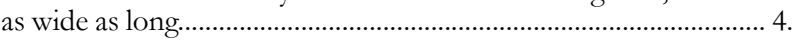
4. Gemmae commonly green to whitish or rarely reddish, frequently absent ............................................................................. 5 . 5. Stem cross section with $1(-2)$ outer layers of thick-walled cell, gemmae 2-celled, ventral lobe not decurrent [distributed throughout around the treated area, but the most common in Boreal part] ………………………………………….... sect. 1. Curtae. 5. Stem cross section 2-4(-5) layers of thick-walled cells, gemmae 1(-2)-celled, ventral lobe shortly decurrent [southern flank of the area] ……............................................................... sect. 2. Stephania. 4. Gemmae commonly red to brown and purple, almost always

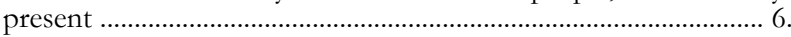
6. Perianth plicate, weakly flattened, mouth contracted; oil-bodies large $(10-15 \mu \mathrm{m}), 1-4(-5)$ per cells, mostly long-persistent .............. 6. Perianth dorsiventrally compressed, mouth truncate; oil-bodies small $(3-10 \mu \mathrm{m}), 2-9$ per cells, commonly fast disappearing ........... 7. 7. Gemmae 2-celled, mostly on small-leaves attenuate shoot tips (with exception of $S$. zemliae, known from northernmost flank of treated area) ………………………………………….... sect. 4. Scapaniella. 7. Gemmae 1-celled, mostly on not modified shoots

. Apiculatae. 3. Ventral lobe broadly obovate to subrounded, $0.85-1.35$ as wide

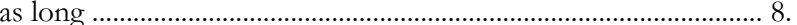

8. Gemmae green, midleaf cells mostly with concave trigones, keel

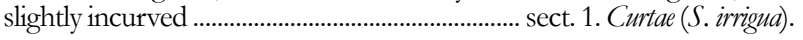
8. Gemmae reddish to brown, midleaf cells mostly with convex trigones or (if concave) keel strongly arcuately incurved ................... ............................................................................ sect. 6. Hyperborea. 1. Ventral lobe distinctly decurrent below keel level, for more than one stem-width ................................................................................. 9.

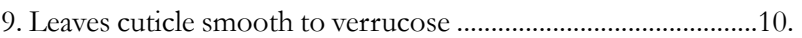
10. Ventral lobe $0.45-0.75$ as wide as long; plants usually small,

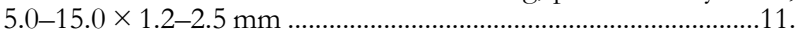
11. Dorsal lobe erect; dorsal and ventral lobe broadly rounded; oilbodies $2-4$ per cells, leaf base sheathing the stem

sect. 8. Cuspiduligerae.

11. Dorsal lobe appressed; dorsal and ventral lobe sharply pointed; oil-bodes 4-12 per cells, leaves distinctly spreading from the base, which is not sheathing ............................................... sect. 9. Umbrosae

10. Ventral lobe $0.75-1.25$ as wide as long; plant usually large $20.0-100.0 \times 2.0-5.0 \mathrm{~mm}$............................................................12.

12. Gemmae 2-celled (except 1-celled in S. uliginosa), green to rarely reddish, sparsely present ......................................... sect. 10. Scapania. 12. Gemmae 1-celled, brown to cinnamon-brown, commonly present ............................................................... sect. 11. Nemorosae. 9. Leaves cuticle strongly, coarsely papillose-verrucose ...sect. 12. Aequilobae.

\section{TAXONOMIC SYSTEM OF SCAPANIA IN THE RUSSIAN FAR EAST}

(numeral in the brackets after section name indicates number of the species in the Russian Far East)

\section{Sect. 1. Curtae (10)}

Species: S. curta, S. parvifolia, S. diplophylloides, S. lingulata,
S. mucronata, S. praetervisa, S. scandica, S. irrigua, S. obcordata, S. magadanica.

Main features: gemmae 2-celled, green; stem cross section with 1(-2) layers of thick-walled cells; ventral lobe not decurrent.

\section{Sect. 2. Stephania (3)}

Species: S. hirosakiensis, S. parvidens, S. parvitexta.

Main features: gemmae 1-celled, green; stem cross section with 2-4(-5) layers of thick-walled cells; leaf cells pachydermous, ventral lobe shortly decurrent.

Sect. 3. Kaalaasia (2)

Species: S. gymnostomophilla, S. ligulifolia.

Main features: gemmae 2-celled, brown; perianth subtubular, plicate; oil-bodies 1-5 per cells, filling cell lumen, brownish, long-persistent.

Sect. 4. Scapaniella (2)

Species: S. glaucocephala, $S$. zemliae.

Main features: gemmae 2-celled, reddish brown; ventral lobe narrowly ovate, obovate to ligulate, $0.45-0.75$ as wide as long.

\section{Sect 5. Apiculatae (3)}

Species: $S$. apiculata, $S$. brevicaulis, $S$. carinthiaca.

Main features: gemmae 1-celled, brown; ventral lobe narrowly ovate, obovate to ligulate, $0.45-0.85$ as wide as long.

Sect. 6. Hyperborea (4)

Species: S. hyperborea, S. degenii, S. tundrae, S. paludicola.

Main features: gemmae 1-2 celled, reddish to brown; ventral lobe broadly ovate to subrounded, $0.85-1.35$ as wide as long.

Sect. 7. Compactae (1)

Species: S. kaurinii.

Main features: gemmae 2-celled, green to yellowish, stem cross section 1-2 layers of thick-walled cells; leaf lobes subequal, dorsal lobe $0.75-0.85$ of ventral lobe size, paroicous.

\section{Sect. 8. Cuspiduligerae (1)}

Species: S. cuspiduligera.

Main features: gemmae 2-celled, reddish; dorsal lobe erect; oil-bodies large, filling cell lumen, 2-3 per cells.

\section{Sect. 9. Umbrosae (1)}

Species: $S$. umbrosa.

Main features: gemmae 2-celled, reddish; dorsal and ventral lobes acute; ventral lobe $0.45-0.7$ as wide as long.

\section{Sect. 10. Scapania (7)}

Species: S. undulata, S. subalpina, S. obscura, S. uliginosa, $S$. paludosa, S. rufidula, S. spitsbergensis.

Main features: gemmae 2-celled (except one-celled in S. uliginosa), commonly green to rarely reddish; dorsal and ventral lobes broadly rounded; ventral lobe $0.75-1.25$ as wide as long.

\section{Sect. 11. Nemorosae (1)}

Species: S. crassiretis.

Main features: gemmae 1-celled, brown to cinnamonbrown; ventral lobe $0.75-1.25$ as wide as long.

\section{Sect. 12. Aequilobae (3 [4?])}

Species: S. sphaerifera, S. ciliata, S. simmonsii, [S. verrucosa $]$.

Main features: gemmae 2(4-8)-celled, brown; leaves with strongly coarsely papillose cuticle. 


\section{Supplementary key directly to species of Scapania}

1. Leaves cuticle smooth to verrucose ................................................ 2. 2. Ventral lobe narrowly ovate to obovate and lingulate, $0.45-0.85$ as wide as long; plants usually small, $5.0-15.0 \times 1.2-2.5 \mathrm{~mm}$.............. 3 .

3. Gemmae commonly green to whitish or rarely reddish ................ 4 . 4. Leaves with marginal 2-4 cells rows equally to subequally thickwalled .

5. Perianth mouth dentate to ciliate, keel $0.4-0.6$ of ventral lobe

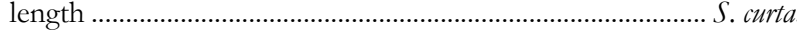

5. Perianth mouth entire to slightly crispate, keel $0.2-0.4$ of ventral lobe length

6. Dorsal lobe apex acute . S. parvifolia.

6. Dorsal lobe apex rounded [plants of diplophylloid appearance] ... S. diplophylloides.

4. Leaves with marginal cells thin-walled, rarely marginal cell row slightly thick-walled near ventral leaf base ........................................... 7 . 7. Dorsal lobe with rounded to obtuse apex; paroicous ......

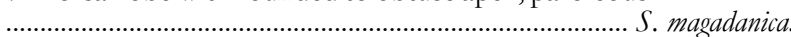

7. Dorsal lobe apex acute; dioicous ................................................... 8

8. Perianth mouth entire to denticulate .................................. S. scandica.

8. Perianth mouth ciliate to lobulate ................................................ 9

9. Plants usually red to purplish brown; perianth plicate near apex and sometimes terete; Lophozia like shoots (with canaliculate and not keeled leaves) commonly present ............................... S. obcordata. 9. Plant usually green to greenish brown; perianth usually dorsiventrally compressed, leaves always distinctly keeled ........................10. 10. Marginal cells usually $19.0-25.0 \mu \mathrm{m}$, ventral lobe apex rounded ........ S. lingulata. 10. Marginal cells usually14.0-20.0 $\mu \mathrm{m}$, ventral lobe with acute to obtuse apex

11. Leaves with dorsal lobe $0.5-0.6$ of ventral lobe, keel $0.5-0.6$ of ventral lobe length, gemmae green, $20.0-25.0 \times 10.0-14.0 \mu \mathrm{m} . . . . . .$.

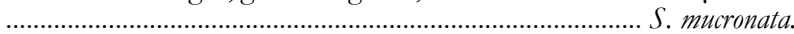

11. Leaves with dorsal lobe $0.6-0.8$ of ventral lobe, keel $0.5-0.7$ of ventral lobe length, gemmae green to reddish brown, $24.0-32.0 \times$ $13.0-16.0 \mu \mathrm{m}$ S. praetervisa.

3. Gemmae commonly red to brown and purple, almost always present .... 12.

12. Ventral lobe not decurrent .

13.

13. Perianth plicate, weakly flattened, mouth contracted; oil-bodies large $(10.0-15.0 \mu \mathrm{m}), 1-4(-5)$ per cells, mostly long-persistent .......

14. Oil-bodies usually one per cells, larger; keel $0.30-0.43$ of ventral lobe length; gemmae smaller, $20.0-25.0 \times 12.5-15.0 \mu \mathrm{m}$

S. gymnostomophila.

14. Oil-bodies usually $2-4$ per cells, smaller; keel $0.60-0.65$ of ventral lobe length; gemmae larger 24.0-32.0 × 16.0-21.0 $\mu \mathrm{m}$ [strictly Arctic] ............................................................................ S. ligulifolia.

13. Perianth dorsiventrally compressed, mouth truncate; oil-bodies small $(3.0-10.0 \mu \mathrm{m}), 2-9$ per cells, commonly fast disappearing ....

.

15. Gemmae 2-celled, mostly on small-leaves attenuate shoot tips (with exception of $S$. zemliae, known from northernmost flank of treated area)

16. Gemmae reddish brown, smaller, 14.0-19.6 × 11.2-14.0 $\mu \mathrm{m}$; leaves not crispate; marginal cells of ventral lobe in 1-2 cell rows thick-walled [on decaying wood in forested area] ..... S. glaucocephala. 16. Gemmae brown, larger $25.0-30.0 \times 12.5-17.5 \mu \mathrm{m}$; leaves slightly crispate; marginal cells of ventral lobe thin-walled; on peaty soil in boggy area [on soil, strictly Arctic] ………………………... S. zemliae.

15. Gemmae 1-celled, mostly on not modified shoots ................. 17. 17. Leaves with marginal $2-3$ cell rows equally thick-walled ... S. carintbiaca.

17. Leaves with marginal cells thin-walled .................................... 18. 18. Gemmiparous shoots gradually narrowed to the apex; ventral lobe $0.45-0.60$ as wide as long; gemmae reddish brown, $11.2-14.0$ $\mu \mathrm{m}$; on decaying wood in forests ..................................... S. apiculata. 18. Gemmiparous shoots dilated to the apex; ventral lobe 0.6-0.7 as wide as long; gemmae deep brown, 15.0-17.5 $\mu \mathrm{m}$; on soil or peat in tundra belt ..................................................... S. brevicaulis.

12. Ventral lobe distinctly decurrent below keel level, for more than one stem-width

19.

19. Dorsal lobe erect; dorsal and ventral lobe broadly rounded; oilbodies $2-4$ per cells, leaf base sheathing the stem .... S. cuspiduligerae. 19. Dorsal lobe appressed; dorsal and ventral lobe sharply pointed; oilbodes 4-12 per cells, leaves distinctly spreading from the base, which is not sheathing …………………………………………………….... S. umbrosae. 2. Ventral lobe $0.75-1.25$ as wide as long; plant usually large 10.0-

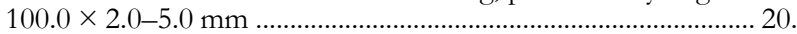
20. Ventral lobe shortly, but distinctly decurrent below keel level, for less than one stem-width ........................................................... 21 . 21 . Leaves with marginal $2-4$ cells rows equally to subequally thick-walled ...................................................................................... 22 22. Dorsal lobe $0.7-0.8$ of ventral size; keel $0.5-0.6$ of ventral lobe length; gemmae green to yellowish brown in full sun ... $S$. parvidens. 22. Dorsal lobe $0.5-0.7$ of ventral size; keel $0.4-0.5$ of ventral lobe length; gemmae green ...................................................... S. parvitexta. 21. Leaves with marginal cells thin-walled, rarely marginal cell row slightly thick-walled near ventral leaf base ...................................... 23 . 23. Leaf lobes subequal, dorsal lobe $0.75-0.85$ the size of ventral lobe; paroicous ................................................................ S. kaurinii. 23. Leaf lobes unequal, dorsal lobe $0.35-0.80$ the size of ventral lobe; dioicous ................................................................................ 24 24. Gemmae green, midleaf cells mostly with concave trigones, keel slightly incurved ............................................................ S. irrigua. 24. Gemmae reddish to brown, midleaf cells mostly with convex trigones or (if concave) keel strongly arcuately incurved ............. 25 . 25 . Keel short, less than 0.25 of ventral lobe length, mostly strongly semicircularly arched; dorsal lobe ca. $0-30^{\circ}$ with stem axis .......... S. paludicola. 25. Keel longer, more than 0.25 of ventral lobe length, slightly to strongly arched; dorsal lobe ca. $10-60^{\circ}$ with stem axis ................ 26. 26. Ventral lobe concave; marginal cells of ventral lobe 24.0-35.0 $\mu \mathrm{m}$; gemmae 21.0-24.0 × 16.0-21.0 $\mu \mathrm{m}$............................ S. tundrae. 26. Ventral lobe flat to convex; marginal cells of ventral lobe 14.0-22.0 $\mu \mathrm{m}$; gemmae $14.0-16.0 \times 10.0-14.0 \mu \mathrm{m}$................................................ 27. 27. Gemmae 1-celled, brown; ventral lobe denticulate at apex; keel slightly to semicircularly arched, perianth strongly compressed, its mouth incurved to ventral side ....................................................... S. degenii. 27. Gemmae 2-celled, pinkish to reddish at maturity; ventral lobe entire; keel straight to slightly arched, perianth loosely compressed,

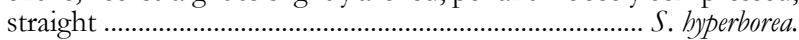
20 . Ventral lobe distinctly decurrent below keel level, for more than one stem-width .......................................................................... 28. 28. Gemmae 1-celled, brown to cinnamon-brown, commonly present ............................................................................. S. crassiretis. 28. Gemmae 2-celled (except 1-celled in $S$. uliginosa), green to rarely reddish, sparsely present …………………………………......... 29 . 29. Leaves and keel with margins entire to denticulate-dentate . 30 . 30. Dorsal lobe distinctly decurrent .................................................. 31 . 31. Keel strongly semicircularly arched, $0.10-0.25$ of ventral lobe length, dorsal lobe $0.55-0.75$ of ventral lobe ....................... S. paludosa. 31. Keel moderately arched, $0.22-0.30$ of ventral lobe length, dorsal lobe $0.25-0.5$ of ventral lobe ......................................................... S. uliginosa. 30. Dorsal lobe not decurrent .......................................................... 32 . 32. Leaves with marginal cells thin-walled; gemmae (1-)2-celled, brown; plants usually blackish .................................................................... S. obscura. 32. Leaves with marginal $1-3$ cell rows equally to subequally thickwalled; gemmae 2-celled, pale green; plant usually green to reddish

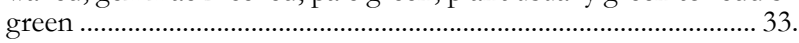

33. Dorsal lobe $0.3-0.6$ of ventral lobe size; keel $0.24-0.40$ of ventral lobe length; stem in cross section with $3-4(-5)$ layers of thick-walled cells along margin ............................................ S. undulata. 33. Dorsal lobe $0.6-0.7$ of ventral lobe size; keel $0.40-0.55$ of ventral lobe length; stem cross section with 1-2 lavers of thick-walled cells along margin ................................................................................. S. subalpina. 29. Leaves and keel with margins ciliate-dentate ............................ 34 . 
34. Keel straight to slightly arched, $0.35-0.45$ of ventral lobe length; dioicous ....................................................................... S. rufidula. 34. Keel semicircularly arched, $0.1-0.3$ of ventral lobe length; paroicous ...................................................................... S. spitsbergensis. 1. Leaves cuticle strongly, coarsely papillose-verrucose ……………..... 35. 35. Dorsal lobe decurrent .................................................................. 36 36. Dorsal and ventral lobes strongly deflexed; trigones strongly bulging; ventral lobe denticulate; strictly Arctic, calciphilous

S simmonsit.

36. Dorsal and ventral lobes slightly convex; trigones triangular; ventral lobe with dense linear cilia; southernmost flank of treated area, South Temperate, acidophilous ..................................... S. ciliata.

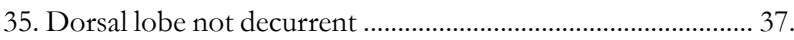
37. Gemmae 1(-2)-celled, elliptical, green; ventral lobe shortly, but distinctly decurrent below keel level, for less than one stemwidth [southern flank of the area] ........................... S. hirosakiensis. 37. Gemmae 2-8-celled, elliptical to spherical or angular, brownish green to brown; ventral lobe distinctly decurrent below keel level, for more than one stem-width ............................................................. 38. 38. Gemmae 4-8-celled, spherical to (rarely) angular; marginal cells thin-walled ....................................................................... S. sphaerifera. 38. Gemmae 2-celled, elliptical to angular; marginal cells equally thick-walled .................................................................... [S. verrucosa].

SCAPANLA SECT. CURTAE Müll. Frib., Rabenh. Krypt.Fl. 2. Aufl. 6(1): 245, 1905.

Scapania sect. Curtae H. Buch, Soc. Sci. Fennica, Comm. Biol. 3(1): 55, 1928.

Scapania sect. Irriguae H. Buch (only type species), Soc. Sci. Fennica, Comm. Biol. 3(1): 84, 1928.

Description: Plants ca. $6.0-15.0 \times 1.5-3.0 \mathrm{~mm}$, prostrate to ascending, yellowish green to green and purplish to deep red and brown. Stems sparsely branched, dorsal surface greenish to pale brown, ventral surface brownish to deep reddish brown, in cross section cortex cells thickwalled in 1(-2) layers. Rhizoids numerous, colorless to pale brown. Leaves contiguous to imbricate; keel $0.3-0.7$ of ventral lobe length, straight to slightly arched; dorsal lobe transversely inserted, not decurrent, obliquely ovate to lanceolate; ventral lobe insertion line slightly arched to straight, not decurrent, obliquely oblong to obovate. Cells in the midleaf oblong-rectangular, with concave trigones. Oil bodies (2-)4-12 per cells, granulate. Specialized asexual reproduction by 2 -celled, green to reddish gemmae. Sexual condition dioicous or paroicous. Perianth oblong to obovate, truncate, dorsiventrally compressed, flat to somewhat plicate.

Species ca. 12 (10 in the flora): North America, Eurasia (Table 1).

\section{Key to the species of Scapania sect. Curtae in the Russian Far East}

1. Leaves with marginal $2-4$ cells rows equally to subequally thick-

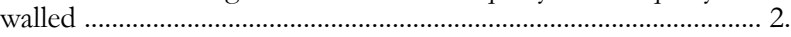
2. Perianth mouth dentate to ciliate, keel $0.4-0.6$ of ventral lobe length ............................................................................ 1. S. curta. 2. Perianth mouth entire to slightly crispate, keel $0.2-0.4$ of ventral

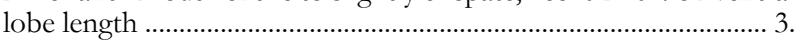
3. Dorsal lobe apex acute .............................................. 2. S. parvifolia. 3. Dorsal lobe apex rounded [plants of diplophylloid appearance] ... 3. S. diplophylloides. 1. Leaves with marginal cells thin-walled, rarely one marginal cell row slightly thick-walled near ventral leaf base .................................................... 4 .
4. Dorsal lobe apex acute; dioicous 5.

4. Dorsal lobe with rounded to obtuse apex; paroicous 10. S. magadanica

5. Ventral lobe $0.5-0.8$ as wide as long, its insertion line straight to slightly arched

5. Ventral lobe $0.7-1.0$ as wide as long, its insertion line distinctly arched ............................................................................ 9. S. irrigua.

6. Perianth mouth ciliate to lobulate .................................................. 7.

6. Perianth mouth entire to denticulate ..................................... 7. S. scandica.

7. Plant usually green to greenish brown; perianth usually dorsiventrally compressed, leaves always distinctly keeled ................................... 8.

7. Plants usually red to purplish brown; perianth plicate near apex and sometimes terete; Lophozia like shoots (with canaliculate and not keeled leaves) commonly present ...................................................... 8. S. obcordata. 8. Marginal cells usually $19-25 \mu \mathrm{m}$, ventral lobe apex rounded ......... 4. S. lingulata.

8. Marginal cells usually14-20 $\mu \mathrm{m}$, ventral lobe with acute to

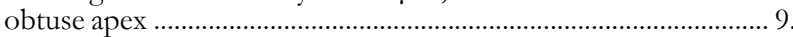
9. Leaves with dorsal lobe $0.5-0.6$ of ventral lobe, keel $0.5-0.6$ of ventral lobe length, gemmae green, $20-25 \times 10-14 \mu \mathrm{m}$

5. S. mucror

9. Leaves with dorsal lobe $0.6-0.8$ of ventral lobe keel $0.5-0.7$ of ventral lobe length, gemmae green to reddish brown, 24-32 $\times$ 13-16 $\mu \mathrm{m}$. 6. S. praetervisa.

1. Scapania curta (Mart.) Dumort., Recueil Observ. Jungerm. 14, 1835. (Fig. 1, 2, 52: 26)

Description: Plants $6.0-10.0 \times 1.5-2.2 \mathrm{~mm}$, prostrate to ascending, yellowish green to green and sometimes reddish in full sun. Stems sparsely branched, dorsal surface greenish pale-brown, ventral surface deep reddish brown, cross section $0.25-0.30 \times 0.20-0.25 \mathrm{~mm}$, cortex cells thick-walled in 1(-2) layers, $12.5-20.0 \times 12.5-17.5 \mu \mathrm{m}$ with reddish pale brown walls; inner cells larger, thin-walled, $12.5-25.0 \times 12.5-22.5 \mu \mathrm{m}$ with colorless walls. Rhizoids numerous, colorless to pale brown. Leaves contiguous to imbricate; keel $0.45-0.55$ of ventral lobe length, straight to slightly arched, ca. $30-60^{\circ}$ with stem axis at the middle part and up to $90-110^{\circ}$ at the end, usually $1-2$ cells lamellatewinged; dorsal lobe transversely inserted, not decurrent, obliquely ovate to lanceolate, $0.70-1.00 \times 0.35-0.60 \mathrm{~mm}$, $0.4-0.5$ of ventral in size, ca. $25-45^{\circ}$ with stem axis, margin entire to sparsely toothed with acute apex, apical tooth 1-2 celled; ventral lobe insertion line slightly arched, not decurrent, obliquely oblong to obovate, 1.0-1.3 $\times 0.5-0.7$ $\mathrm{mm},(0.5-0.6: 1)$, ca. $30^{\circ}-80^{\circ}$ with stem axis, margin entire to sparsely toothed with rounded, obtuse to acute apex. Cells in the midleaf oblong-rectangular, 20.0-25.0(32.0) $\times(12.0) 17.5-22.5 \mu \mathrm{m}$ with concave trigones; near apex (10.0)12.5-15.0 × 12.5-20.0 $\mu \mathrm{m}$, along margin with $1-2(-3)$ cell rows equally thick-walled; at the base $25.0-37.5 \times 12.5$ $25.0 \mu \mathrm{m}$ with concave trigones; cuticle slightly striolate. Specialized asexual reproduction by gemmae in masses at apices of leaf-lobes, elliptical, 17.5-20.0 × 10.0-12.5 $\mu \mathrm{m}$, 2 -celled, pale green. Sexual condition dioicous. Androecia intercalary, bracts in 3-6 pairs, similar to leaves, but inflated in the base, keel $0.6-0.8$ of ventral lobe length, $1-4$ androus, body ca. $200 \times 150 \mu \mathrm{m}$, antheridial stalk 1-seriate, ca. 80 $120 \mu \mathrm{m}$ long. Gynoecia terminal, bracts in 1 pair, slightly larger than sterile leaves, dorsal lobe 1.0-1.2 × 0.5-0.6 mm; ventral lobe $1.4-1.5 \times 0.6-0.7 \mathrm{~mm}$. Perianth oblong to obovate, truncate, somewhat plicate, $1.8-2.0 \times 0.7-0.9 \mathrm{~mm}$, 


\begin{tabular}{|c|c|c|c|c|c|c|c|c|c|c|c|}
\hline 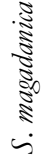 & 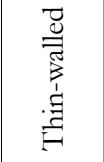 & 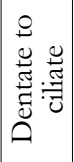 & 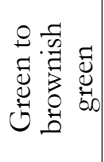 & $\left|\begin{array}{c|}0 \\
0 \\
1 \\
1 \\
0 \\
0\end{array}\right|$ & 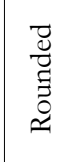 & \begin{tabular}{|l}
$\infty$ \\
0 \\
0 \\
0 \\
0
\end{tabular} & $\mid \begin{array}{l}n \\
0 \\
0 \\
1 \\
0 \\
0 \\
0\end{array}$ & 营 & $\begin{array}{l}0 \\
\dot{0} \\
i \\
0 \\
0 \\
\dot{0}\end{array}$ & 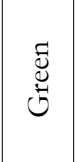 & 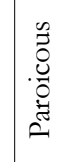 \\
\hline 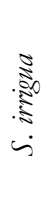 & 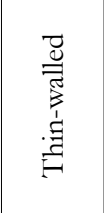 & 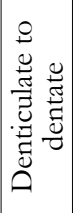 & 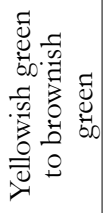 & $\mid \begin{array}{c}0 \\
\stackrel{1}{n} \\
0 \\
1 \\
\\
0\end{array}$ & 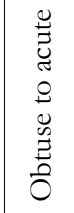 & $\begin{array}{l}0 \\
0 \\
1 \\
n \\
0 \\
0\end{array}$ & $\mid \begin{array}{c}8 \\
+1 \\
1 \\
1 \\
0 \\
0\end{array}$ & 营 & $\begin{array}{l}\vec{t} \\
\vec{J} \\
\vec{d} \\
\dot{ \pm}\end{array}$ & 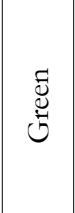 & 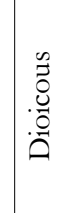 \\
\hline 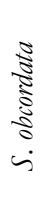 & 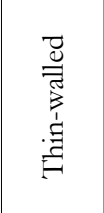 & 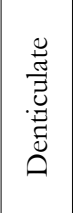 & 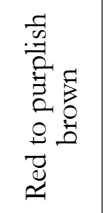 & 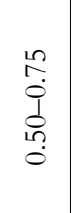 & 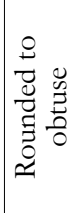 & $\begin{array}{l}\infty \\
0 \\
0 \\
1 \\
0 \\
0\end{array}$ & $\mid \begin{array}{l}0 \\
0 \\
0 \\
1 \\
0 \\
0 \\
0\end{array}$ & 营 & $\begin{array}{c}\hat{i} \\
\hat{N} \\
\underline{1} \\
\dot{v}\end{array}$ & 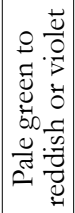 & 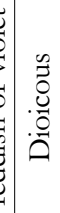 \\
\hline 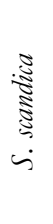 & 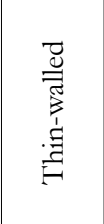 & 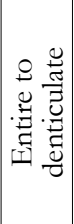 & 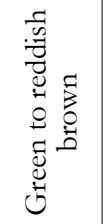 & \begin{tabular}{|c|}
1 \\
1 \\
0 \\
0 \\
1 \\
1 \\
0 \\
0
\end{tabular} & 莺 & $\begin{array}{l}0 \\
0 \\
1 \\
1 \\
0 \\
0\end{array}$ & $\mid \begin{array}{l}0 \\
0 \\
0 \\
1 \\
0 \\
0 \\
0\end{array}$ & 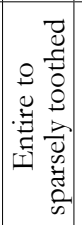 & $\begin{array}{l}0 \\
\stackrel{0}{0} \\
\vec{d} \\
\dot{\Xi}\end{array}$ & 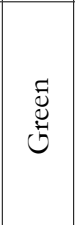 & 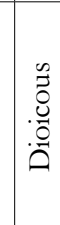 \\
\hline 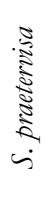 & 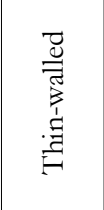 & 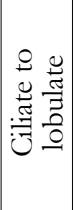 & 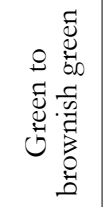 & $\mid \begin{array}{c}\hat{0} \\
1 \\
1 \\
0\end{array}$ & 苞 & $\begin{array}{l}\infty \\
0 \\
0 \\
0 \\
0 \\
0\end{array}$ & $\mid \begin{array}{l}0 \\
0 \\
0 \\
1 \\
0 \\
0 \\
0\end{array}$ & 藏 & 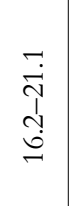 & 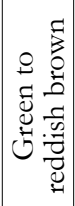 & 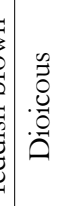 \\
\hline $\begin{array}{l}\text { है } \\
\text { है } \\
\text { है } \\
\dot{\omega}\end{array}$ & 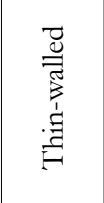 & 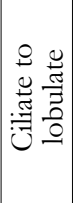 & 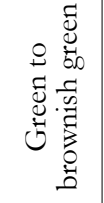 & $\mid \begin{array}{c}0 \\
0 \\
1 \\
1 \\
0 \\
0\end{array}$ & 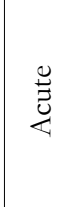 & $\begin{array}{l}0 \\
0 \\
1 \\
n \\
0\end{array}$ & $\mid \begin{array}{l}0 \\
0 \\
0 \\
0 \\
0 \\
0 \\
0\end{array}$ & 莺 & $\begin{array}{l}0 \\
\stackrel{0}{0} \\
\overrightarrow{1} \\
\dot{ \pm} \\
\dot{\sim}\end{array}$ & 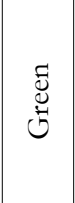 & 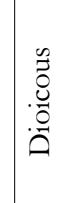 \\
\hline 胥 & 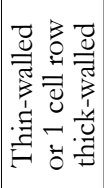 & 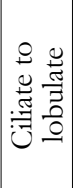 & 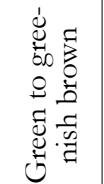 & $\mid \begin{array}{c}0 \\
0 \\
1 \\
1 \\
0\end{array}$ & 苞 & $\begin{array}{l}\hat{1} \\
\hat{1} \\
n \\
0\end{array}$ & $\mid \begin{array}{l}P \\
0 \\
0 \\
0 \\
0 \\
0\end{array}$ & 总 & 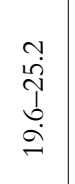 & 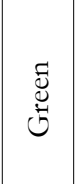 & 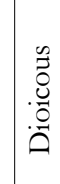 \\
\hline 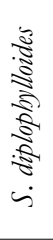 & 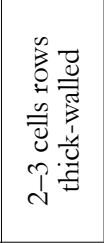 & 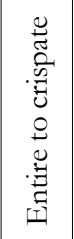 & 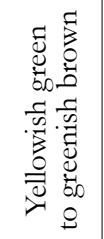 & $\begin{array}{l}t \\
0 \\
1 \\
⿱ \\
0 \\
0\end{array}$ & 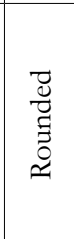 & $\begin{array}{l}+ \\
0 \\
1 \\
3 \\
0\end{array}$ & $\left|\begin{array}{l}0 \\
0 \\
0 \\
\tilde{d}\end{array}\right|$ & 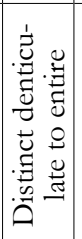 & $\begin{array}{c}\stackrel{N}{\exists} \\
\vec{J} \\
\infty \\
\infty\end{array}$ & 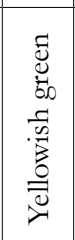 & 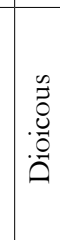 \\
\hline 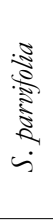 & 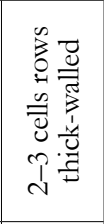 & 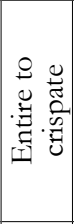 & 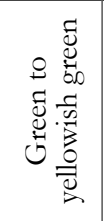 & $\mid \begin{array}{c}t \\
0 \\
1 \\
1 \\
\\
0\end{array}$ & 苞 & $\begin{array}{c}t \\
0 \\
\vdots \\
\vdots \\
0 \\
0\end{array}$ & $\begin{array}{l}0 \\
0 \\
0 \\
1 \\
1 \\
+ \\
0\end{array}$ & 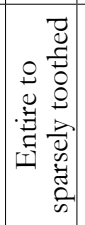 & 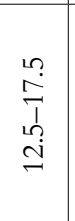 & 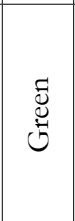 & 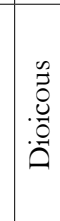 \\
\hline 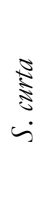 & 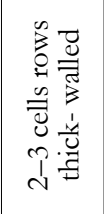 & 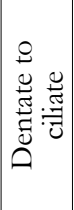 & 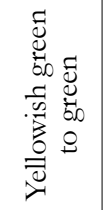 & $\begin{array}{c}1 n \\
n \\
0 \\
1 \\
1 \\
f \\
0 \\
0\end{array}$ & 苞 & $\begin{array}{l}0 \\
0 \\
\vdots \\
0 \\
0\end{array}$ & $\begin{array}{l}0 \\
0 \\
0 \\
1 \\
0 \\
0 \\
0\end{array}$ & 总 & 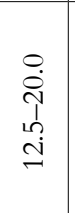 & 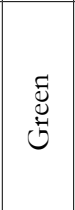 & 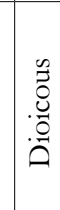 \\
\hline 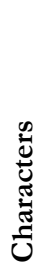 & 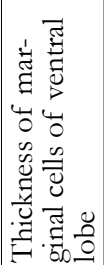 & 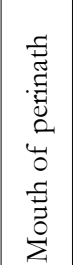 & $\begin{array}{l}\frac{\tilde{0}}{0} \\
0 \\
0 \\
0 \\
\frac{\pi}{a} \\
\frac{\pi}{a}\end{array}$ & 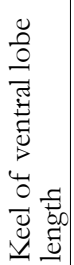 & 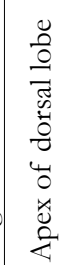 & 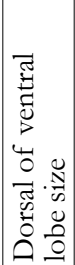 & 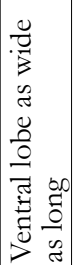 & 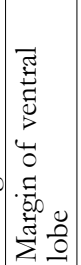 & 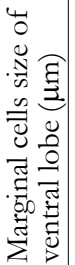 & $\begin{array}{l}\tilde{\sharp} \\
\tilde{\Xi} \\
\text { हुँ } \\
0\end{array}$ & $\begin{array}{l}0 \\
0 \\
0 \\
0 \\
0\end{array}$ \\
\hline
\end{tabular}

mouth dentate, with teeth 2-4 cells long, 1-2 cells wide, slightly lobulate.

Habitat: Fine-grained soil or shaded wet rocks covered with thin soil along streams and roadsides in Boreal and Arctic (taiga and tundra zones); 15-1400 m alt.

Distribution ${ }^{4}$ : Khabarovsky Territory, Sakhalin Province, Kamchatka Territory, Magadan Province, Chukotka Province.

Specimens examined: SAKHALIN PROVINCE, Iturup Island, VB 5 K-66-17-05 (VBGI), K-714-05 (VBGI), Sakhalin Island, Pilenga River, VB S-29-22-09 (VBGI), Nabil'sky Range, VB S-31-106 (VBGI); KAMCHATKA TERRITORY, Commanders, Mednyj Island, VB K-68-9-04 (VBGI), East Kamchatka, Ushkovsky Volcano, VB K-64-103 (VBGI), VB K-58-5-03 (VBGI), Pinachevskaya River, VB K-59-3b-01 (VBGI), Central Kamchatka, Tigil' River Basin, VB K-132-14-04 (VBGI); MAGADAN PROVINCE, Magadan city area, VB Mag-19-2-10 (VBGI).

2. Scapania parvifolia Warnst., Hedwigia 63: 78, 1921.

Scapania scandica f. parvifolia (Warnst.) Schljakov, Pechyon. mkhi severa SSSR 4: 152, 1981.

Description: Plants 8.0-15.0 × 1.5-2.5 $\mathrm{mm}$, prostrate to ascending, green to yellowish green or greenish brown. Stems sparsely branched, dorsal surface brownish to reddish brown, ventral surface deep reddish brown, cross section $0.30-0.40 \times 0.25-0.35 \mathrm{~mm}$, cortex cells thick-walled in 1-2(-3) layers, $12.5-17.5 \times 10.0-15.0 \mu \mathrm{m}$ with reddish brown walls; inner cells larger, thin-walled, 15.0-30.0 $\times 15.0-22.5 \mu \mathrm{m}$ with colorless walls. Rhizoids sparse to common, colorless to pale brown. Leaves contiguous to imbricate; keel 0.25 0.40 of ventral lobe length, straight to slightly arched, ca. $20-30^{\circ}$ with stem axis at the middle part and up to $90-110^{\circ}$ at the end; dorsal lobe subtransversely inserted, not decurrent, obliquely ovate to lanceolate, $0.6-0.8 \times 0.3-$ $0.5 \mathrm{~mm}, 0.3-0.5$ of ventral in size, ca. $20-40^{\circ}$ with stem axis, margin entire to denticulate, apex acute; ventral lobe insertion line slightly arched, not decurrent, obliquely oblong to obovate, $0.8-1.3 \times 0.4-0.6 \mathrm{~mm},(0.45-0.60: 1)$, ca. $60-90^{\circ}$ with stem axis, margin entire with rounded to obtuse apex. Cells in the midleaf polygonal, $15.0-37.5 \times 12.0-25.0 \mu \mathrm{m}$ with distinct triangular trigones; near apex 10.0 $15.0 \times 12.5-17.5 \mu \mathrm{m}$, along margin $2-3$ cells rows equally thick-walled; at the base (20.0) $27.5-50.0 \times 13.0-27.5 \mu \mathrm{m}$ with small triangular trigones; cuticle faintly to distinctly papillose. Oil bodies $3-5$ per cells, elliptical to (rarely) spherical, 4.5-5.5(-6.0) $\times$ 5.5-8.0(-10.0) $\mu \mathrm{m}$,

${ }^{4}$ Here and below the distribution reflects both our study results and literature data placed in Bakalin (2010)

${ }^{5}$ Here and below "VB" is abbreviation from Vadim Bakalin 
granulate. Specialized asexual reproduction by gemmae in masses at apices of leaf-lobes, elliptical, 15.0-20.0 $\times$ 10.0-12.5 $\mu \mathrm{m}$, 2-celled, pale green. Sexual condition dioicous. Androecia intercalary, bracts in 3-4 pairs, similar with leaves, but inflated in the base, 1-6-androus, body ca. $200.0 \times 150.0 \mu \mathrm{m}$, antheridial stalk 1 -seriate, ca. $150.0 \mu \mathrm{m}$ long. Gynoecia terminal, bracts in 1 pair, slightly larger than sterile leaves, dorsal lobe $1.00-1.20 \times 0.80-0.85 \mathrm{~mm}$; ventral lobe $1.6-1.8 \times 1.0-1.2 \mathrm{~mm}$. Perianth oblong to obovate, truncate, somewhat plicate, $2.0-2.5 \times 1.4-1.7 \mathrm{~mm}$, mouth entire to slightly crispate.

Varieties 2 (2 in the flora): Eurasia, North America.

\section{Key to varieties of Scapania parvifolia}

1. Marginal cells of ventral lobe 15.0-30.5 × 12.0-23.0 $\mu \mathrm{m}$.

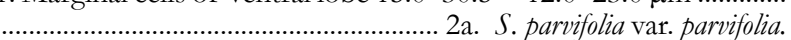
1. Marginal cells of ventral lobe $24.3-32.4 \times 21.0-24.3 \mu \mathrm{m}$ 2b. S. parvifolia var. grandiretis. 2a. Scapania parvifolia var. parvifolia (Fig. 3)

Description: Plants $8.0-15.0 \times 1.5-2.5 \mathrm{~mm}$, prostrate to ascending, green to yellowish green or greenish brown. Stems sparsely branched, in cross section $0.30-0.40$ $\times 0.25-0.35 \mathrm{~mm}$, cortex cells thick-walled in 1-2(-3) layers. Leaves contiguous to imbricate; keel $0.25-0.40$ of ventral lobe length, straight to slightly arched; dorsal lobe subtransversely inserted, not decurrent, obliquely ovate to lanceolate, $0.3-0.5$ of ventral in size; ventral lobe line insertion slightly arched, not decurrent, obliquely oblong to obovate, margin entire with rounded to obtuse apex. Cells in the midleaf polygonal, $15.0-30.5 \times 12.0-23.0 \mu \mathrm{m}$ with distinct triangular trigones; near apex 10.0-15.0 × 12.5-17.5 $\mu \mathrm{m}$, along margin with $2-3$ cells rows equally thick-walled; at the base $27.5-50.0 \times 25.0-27.5 \mu \mathrm{m}$ with small triangular trigones.

Habitat: Peaty soil or over peat-moss in boggy areas in tundra zone and belt, wet fine-grained ground in forested area; $18-1600 \mathrm{~m}$ alt.

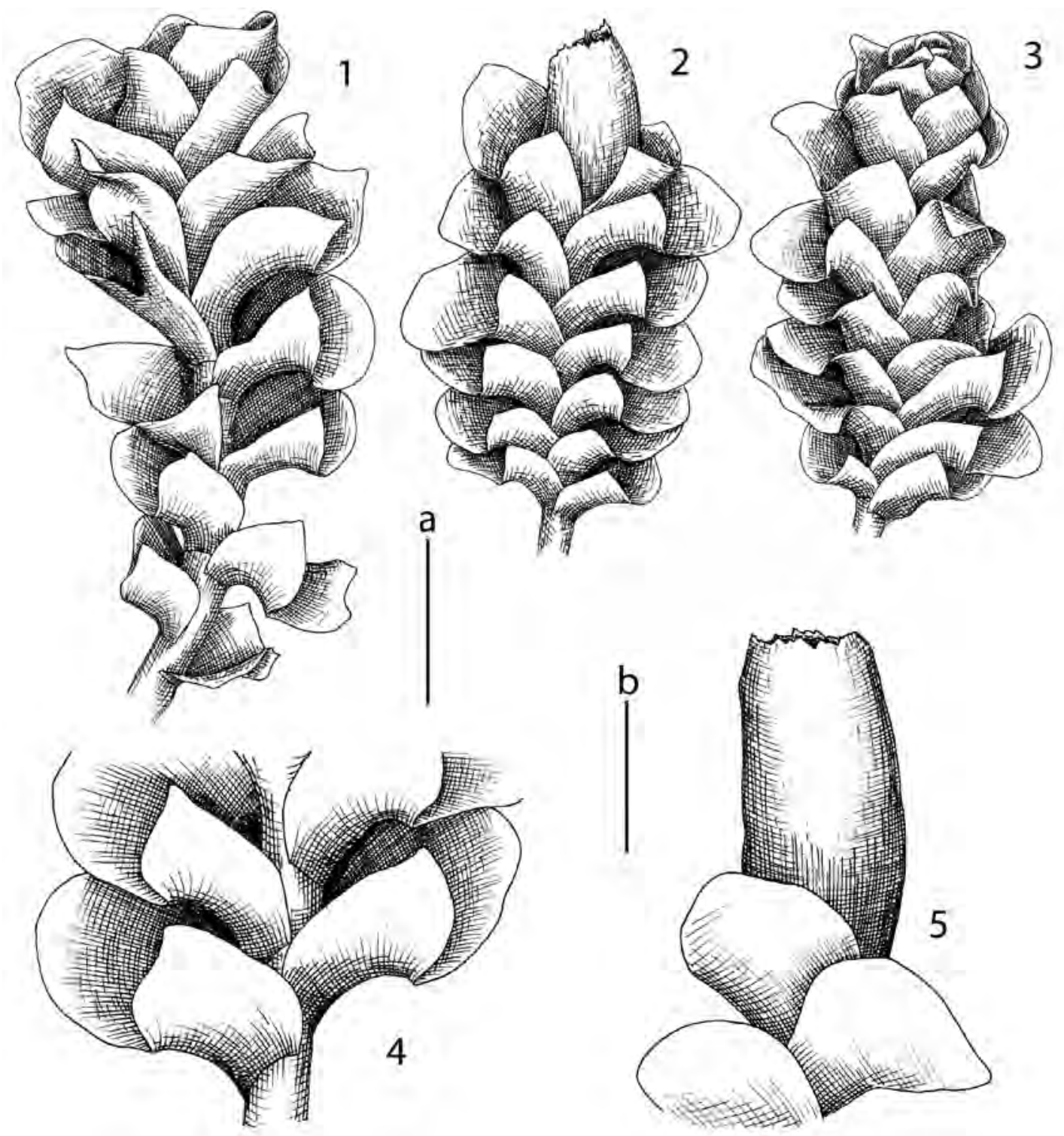

Figure 1 Scapania curta (Mart.) Dumort. 1 - habit, dorsal view; 2 - perianthous plant, dorsal view; 3 - androecious plant, dorsal view; 4 - part of shoot, dorsal view; 5 - upper part of perianthous shoot, dorsal view. Scales: a $-1 \mathrm{~mm}$, for $1-3 ; \mathrm{b}-500 \mu \mathrm{m}$, for 4,5 . 


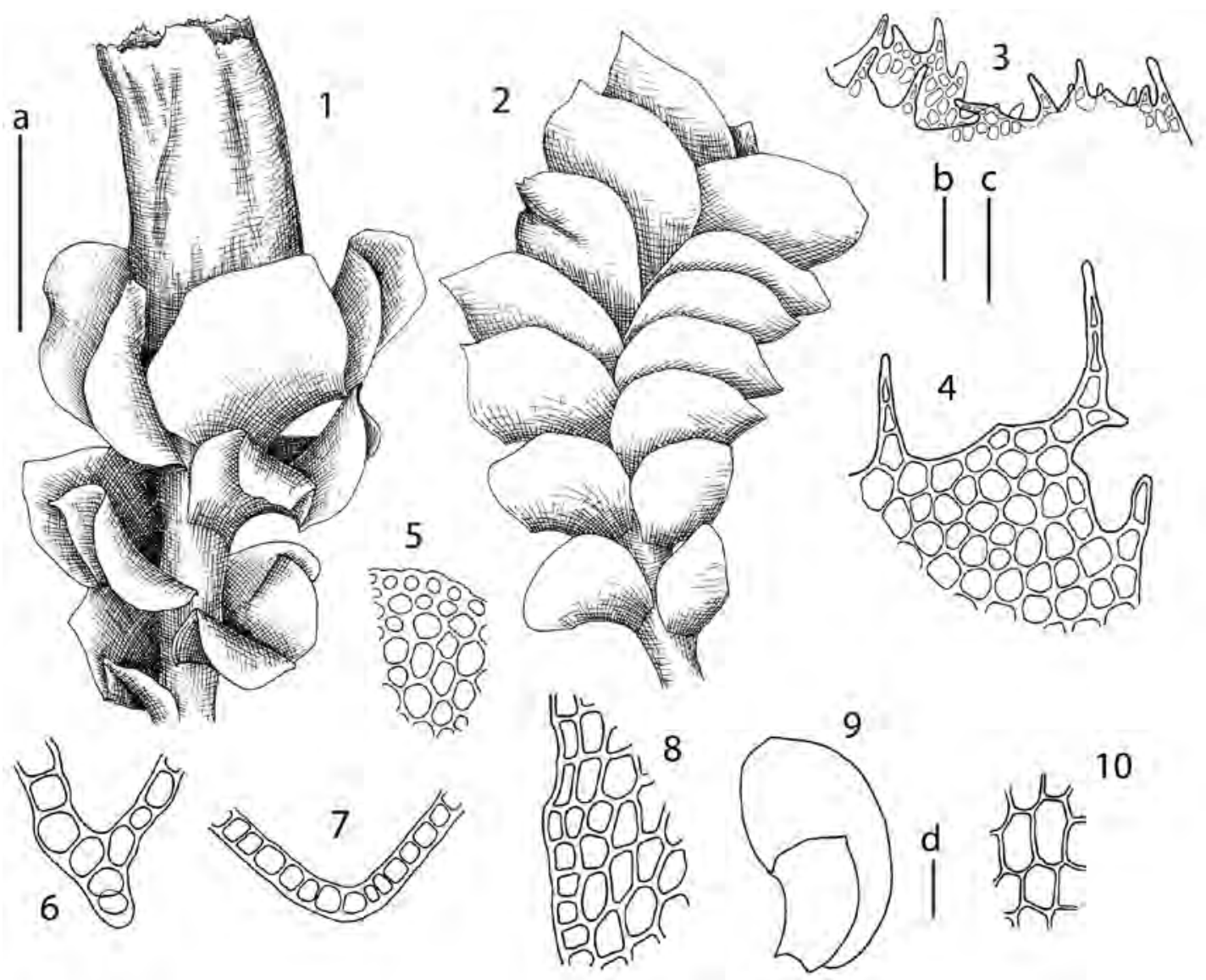

Figure 2 Scapania curta (Mart.) Dumort. 1 - perianthous plant, dorsal view; 2 - habit, ventral view; 3, 4 - perianth mouth armature; 5 - stem cross section, fragment; 6,7 - keel cross section; 8 - leaf margin; 9 - leaf; 10 - midleaf cells. Scales: $\mathrm{a}-1 \mathrm{~mm}$, for 1,$2 ; \mathrm{b}-100 \mu \mathrm{m}$, for $3 ; \mathrm{c}-50 \mu \mathrm{m}$, for $4-8,10 ; \mathrm{d}-200 \mu \mathrm{m}$, for 9 .

Distribution: Primorsky Territory, Khabarosk Territory, Sakhalin Province, Kamchatka Territory, Magadan Province, Chukotka Province.

Specimens examined: SAKHALIN PROVINCE, Sakhalin Island, Nabil'sky Range, VB S-27-14a-06, S-27-8b-06 (VBGI), Korsakovsky District, VB S-66-5-09 (VBGI), KHABAROVSK TERRITORY, Okhotsk District, VB Kh-45-7-08 (VBGI), Solnechnyj District, VB Kh-8-3-07 (VBGI); MAGADAN PROVINCE, Srednekansky District, VB Mag-14-21-10, Mag-14-23-10 (VBGI), VB Mag-17-19-10 (VBGI).

2b. Scapania parvifolia var. grandiretis Schljakov, Novosti Syst. Nizsh. Rast. 8: 332, 1971.

Scapania scandica var. grandiretis (Schljakov) Schljakov, Pechyon. mkhi severa SSSR 4: 152, 1981. (Fig. 4, 52: 11)

Description: Plants $8.0-15.0 \times 1.5-2.5 \mathrm{~mm}$, prostrate to ascending, reddish brown. Stems sparsely branched, in cross section $0.26-0.30 \times 0.18-0.23 \mathrm{~mm}$, cortex cells thickwalled in 1 layer. Leaves contiguous; keel $0.45-0.55$ of ventral lobe length, straight to slightly arched; dorsal lobe transversely inserted, not decurrent, obliquely obovate, 0.5-0.6 of ventral in size; ventral lobe transversely inserted, insertion line slightly arched, not decurrent, obliquely oblong to obovate, margin entire to sometimes scattered denticulate, apex rounded to acute. Cells in the midleaf polygonal, $24.3-32.4 \times 21.0-24.3 \mu \mathrm{m}$ with triangular trigones; near apex 16.2-21.0 $\times 21.0-24.3 \mu \mathrm{m}$, along margin thin- to thick-walled; at the base 48.6-64.8 × 24.3-32.4 $\mu \mathrm{m}$ with triangular trigones.
Habitat: Peaty soil or peat-moss in boggy areas in tundra zone; $100 \mathrm{~m}$ alt.

Distribution: Kamchatka Territory.

Specimens examined: KAMCHATKA TERRITORY, Commander Island, VB K-56-03-03 (KPABG, VBGI), Northern Kamchatka, Anadyrka River, VB K-28-9-03 (KPABG, VBGI).

3. Scapania diplophylloides Amakawa et S. Hatt., J. Hattori Bot. Lab. 9: 59. f. 6: 11-16, 1953. (Fig. 5, 52: 23)

Description: Plants $10.0-15.0 \times 2.0-3.0 \mathrm{~mm}$, ascending, yellowish green to greenish brown. Stems sparsely branched, dorsal surface greenish brown, ventral surface reddish brown to brown, cross section $0.38-0.45 \times 0.25$ $0.30 \mathrm{~mm}$, cortex cells thick-walled in 1-2(-3) layers, 14.0 $19.6 \times 11.2-14.0 \mu \mathrm{m}$ with brown walls; inner cells larger, thin-walled, 19.6-28.0 × 19.6-28.0 $\mu \mathrm{m}$ with colorless walls. Rhizoids sparse to common, colorless to pale brown. Leaves contiguous to imbricate; keel $0.3-0.4$ of ventral lobe length, straight to slightly arched, ca. $30-50^{\circ}$ with stem axis at the middle part and up to $90^{\circ}$ at the end; dorsal lobe subtransversely to transversely inserted, not decurrent, obovate, $0.50-1.00 \times 0.50-0.65 \mathrm{~mm}, 0.3-0.4$ of ventral in size, ca $20^{\circ}-30^{\circ}$ with stem axis, margin entire, apex rounded; ventral lobe transversely inserted, insertion line slightly arched, not decurrent, obliquely oblong to obovate, $1.25-2.00$ $\times 0.75-1.00 \mathrm{~mm},(0.5: 1)$, ca. $40-60^{\circ}$ with stem axis, margin entire to remotely denticulate, apex rounded. Cells in the midleaf oblong-rectangular, (15.0)22.4-(15.0)28.0 $\times$ 


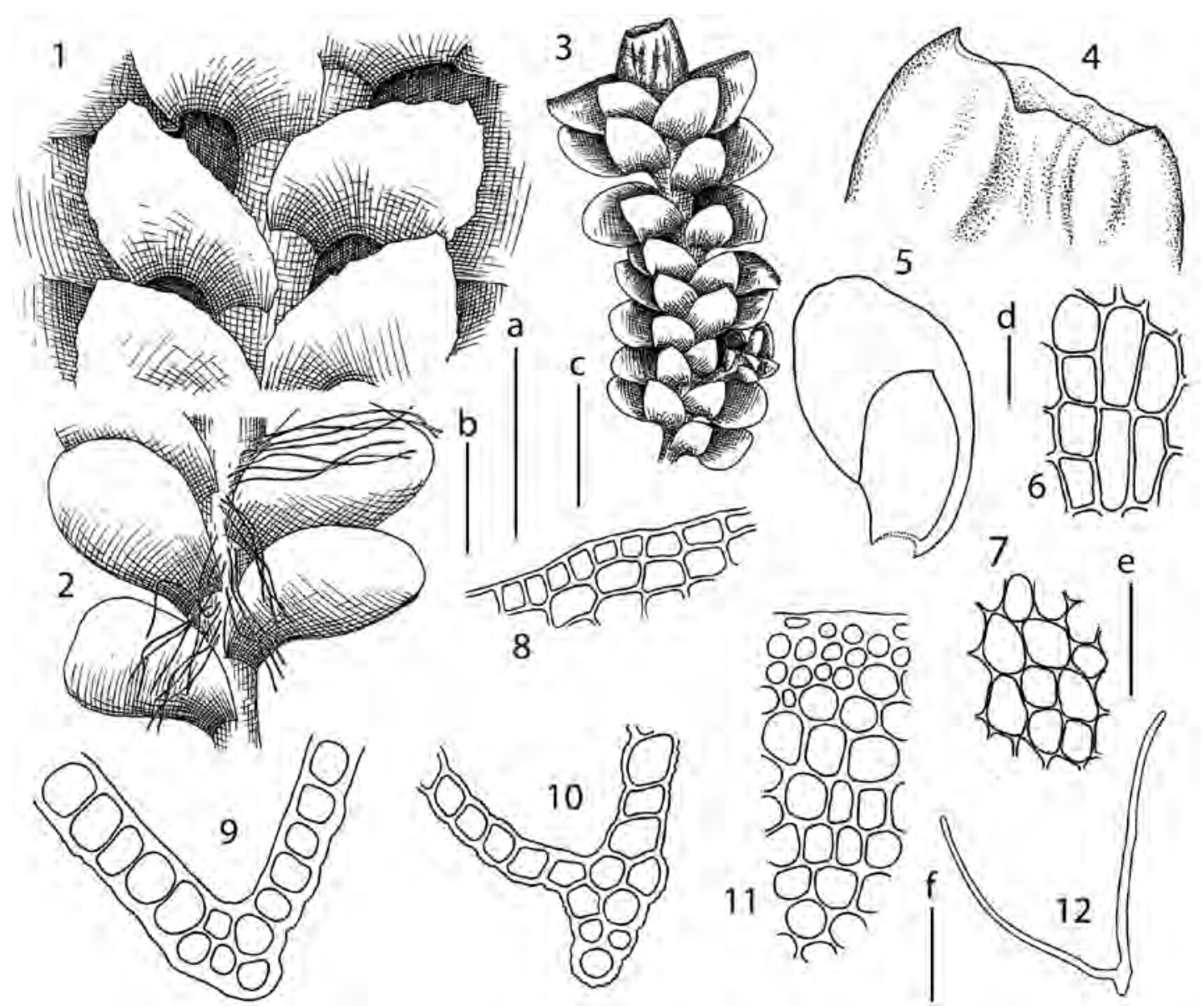

Figure 3 Scapania parvifolia Warnst. 1 - part of shoot, dorsal view; 2 - part of shoot, ventral view; 3 - perianthous plant, dorsal view; 4 - perianth mouth; 5 - leaf; 6 - lobe base cells; 7 - midleaf cells; 8 - perianth mouth armature; 9, 10; keel cross section; 11 - stem cross section, fragment; 12 - leaf cross section. Scales: $\mathrm{a}-1 \mathrm{~mm}$, for $1 ; \mathrm{b}-1 \mathrm{~mm}$, for $2 ; \mathrm{c}-2$ $\mathrm{mm}$, for $3, \mathrm{~d}-200 \mu \mathrm{m}$, for 4 ; e $-50 \mu \mathrm{m}$, for $6-11 ; \mathrm{f}-200 \mu \mathrm{m}$, for 12 .

14.0-28.0 $\mu \mathrm{m}$ with triangular trigones; near apex 8.4-11.2 $\times 8.4-11.2 \mu \mathrm{m}$, along margin $2-3$ cell rows thick-walled; at the base $42.0-67.2 \times 22.4-28.0 \mu \mathrm{m}$, with concave trigones; cuticle smooth to slightly striolate. Specialized asexual reproduction rarely occur, by gemmae in masses at apices of leaf-lobes, elliptical, 14.0-19.6 × 5.6-8.4 $\mu \mathrm{m}$, 2-celled, pale green. Sexual condition dioicous. Androecia intercalary, bracts in 4-8 pairs, similar to leaves but inflated in the base, 1-4-androus, body ca. $190.0 \times 160.0 \mu \mathrm{m}$, antheridial stalk 1-seriate, ca. 110.0-200.0 $\mu \mathrm{m}$ long. Gynoecia terminal, bracts in 1 pair, slightly larger than sterile leaves, dorsal lobe $0.60-1.00 \times 0.50-0.75 \mathrm{~mm}$; ventral lobe $1.5-2.0 \times 0.5-1.0$ $\mathrm{mm}$. Perianth oblong to obovate, weakly dorsiventrally compressed, truncate, $2.0-2.5 \times 1.4-1.7 \mathrm{~mm}$, mouth entire to slightly crispate.

Habitat: Decaying wood, wet fine-grained soil near roadsides; in forested areas with humid climate; 100-1174 $\mathrm{m}$ alt.

Distribution: Primorsky Province, Sakhalin Province.

Specimens examined: PRIMORSKY TERRITORY, Shkotovsky District, VB P-73-21-05 (VBGI); SAKHALIN PROVINCE, Iturup Island, VB K-16-44-07, K-56-18-05 (VBGI), Shikotan Island, VB K-36-2-07, K-36-25-07, K-36-37-07 (VBGI), Kunashir Island, VB K-38-8-06 (VBGI), Sakhalin Island, Due(Dui) Bay, VB S-59-10-09, S-59-14-09 (VBGI), Kamyshovyj Range, VB S-57-1609 (VBGI), Rogatka River, VB S-34-3-05 (VBGI), Belaya River, VB S-25-24-06 (VBGI), Nevel'sky District, VB S-68-1-09, S-689-09 (VBGI).
4. Scapania lingulata H. Buch, Meddeland. Soc. Fauna Fl. Fenn. 42: 92, 1916. (Fig. 6, 52: 17)

Description: Plants $6.0-15.0 \times 2.0-3.0 \mathrm{~mm}$, prostrate to ascending, green to greenish brown. Stems sparsely branched, dorsal surface reddish brown, ventral surface deep reddish brown to brown, cross section $0.38-0.45 \times 0.25-0.30$ $\mathrm{mm}$, cortex cells thick-walled in 1-2 layers, 11.2-14.0 $\times$ 8.4-11.2 $\mu \mathrm{m}$, with reddish brown walls; inner cells larger, thin-walled, $14.0-28.0 \times 14.0-28.0 \mu \mathrm{m}$, with colorless walls. Rhizoids sparse to common, colorless to pale brown. Leaves contiguous; keel $0.5-0.6$ of ventral lobe length, straight to slightly arched, ca. $50^{\circ}-70^{\circ}$ with stem axis at the middle part and up to $90^{\circ}$ at the end; dorsal lobe transversely inserted, not decurrent, obliquely ovate to obovate, convex, $0.75-1.00$ $\times 0.50-0.75 \mathrm{~mm}, 0.5-0.7$ of ventral in size, ca. $40-60^{\circ}$ with stem axis, margin entire, apex acute; ventral lobe transversely inserted, insertion line slightly arched, not decurrent, obliquely oblong to obovate, $1.00-1.50 \times 0.75-1.00 \mathrm{~mm},(0.6-0.7$ : 1), ca. $50-70^{\circ}$ with stem axis, margin entire with rounded to obtuse apex, sometimes with scattered marginal small teeth. Cells in the midleaf oblong-rectangular, (14.0)18.0-36.4 $\times$ (12.0-)19.6-28.0 $\mu \mathrm{m}$, with triangular trigones; near apex 14.0-22.4 × 14.0-16.8 $\mu \mathrm{m}$, along margin with 1 cell row thick-walled or thin-walled throughout; at the base 42.0-56.0 $\times 28.0-33.6 \mu \mathrm{m}$ with triangular trigones; cuticle striolate. Oil bodies $4-7$ per cells, elliptical, 5.0-9.0(-11.0) $\times 4.5-6.0 \mu \mathrm{m}$, 

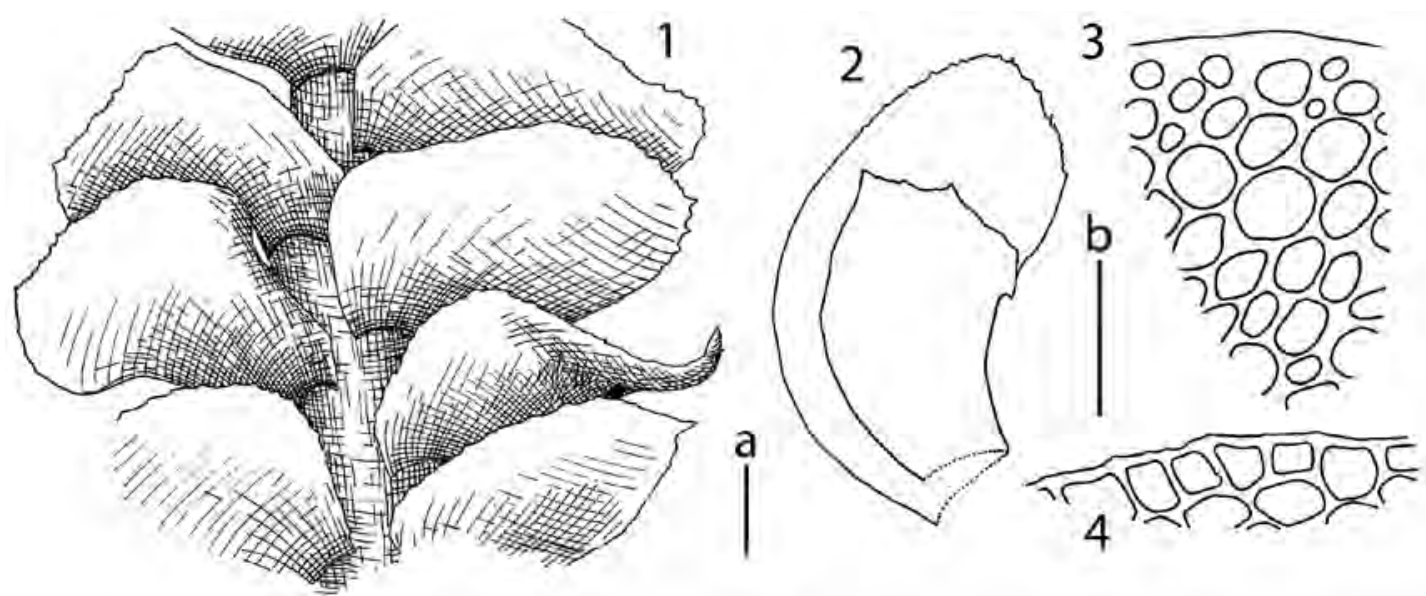

Figure 4 Scapania parvifolia var. grandiretis Schljakov 1 - part of shoot, ventral view; 2 - leaf; 3 - stem cross section; 4 leaf margin. Scales: $\mathrm{a}-200 \mu \mathrm{m}$, for 1,$2 ; \mathrm{b}-50 \mu \mathrm{m}$, for 3, 4 .

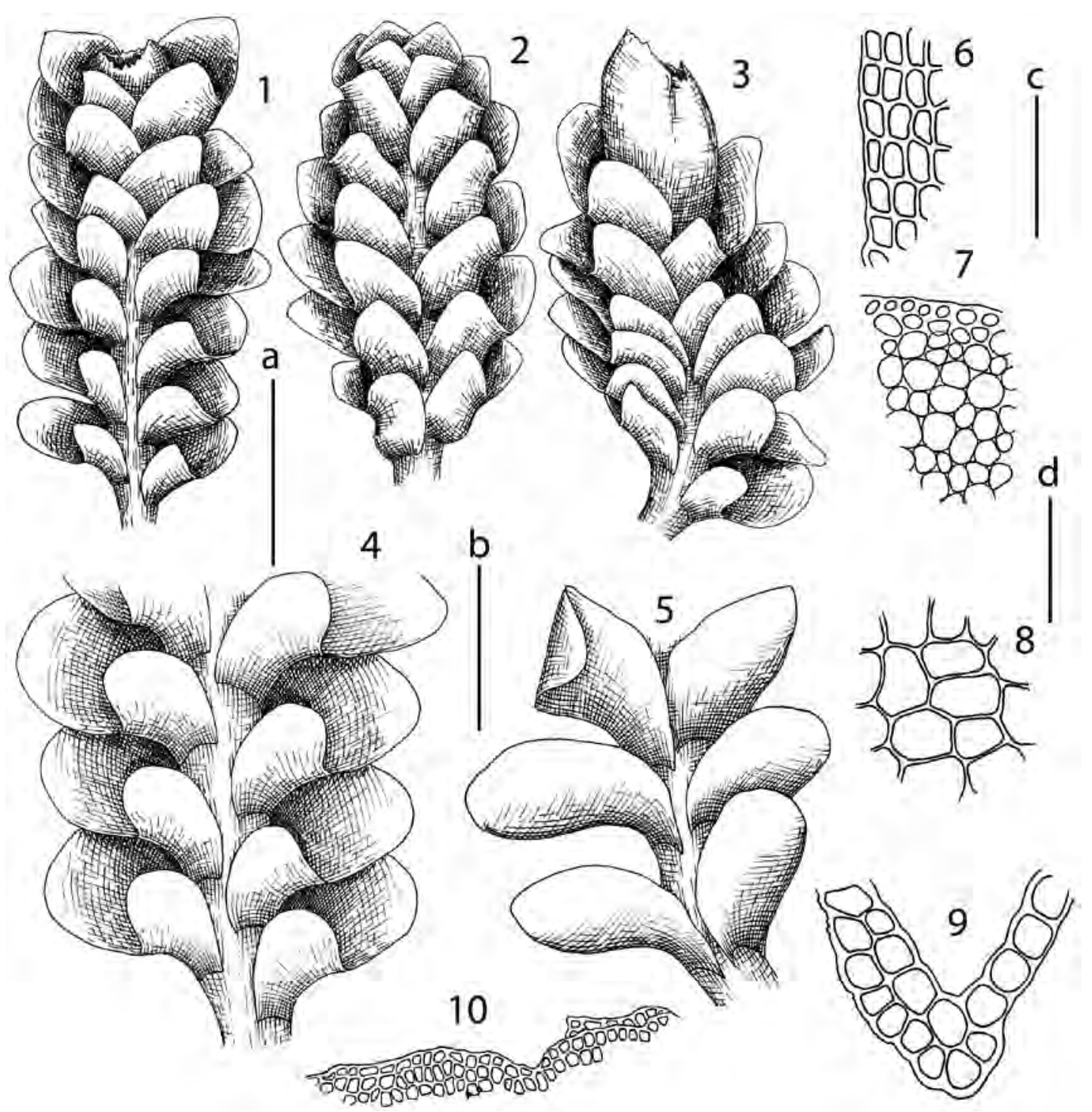

Figure 5 Scapania diplophylloides Amakawa et S. Hatt. 1 - habit, dorsal view; 2 - androecious pant, dorsal view; 3 perianthous plant, dorsal view; 4 - part of shoot, dorsal view; 5 - part of shoot, ventral view; 6 - leaf margin; 7 - stem cross section, fragment; 8 - midleaf cells; 9 - keel cross section; 10 - perianth mouth armature. Scales: a $-2 \mathrm{~mm}$, for $1-3 ; \mathrm{b}-1 \mathrm{~mm}$, for 4,$5 ; \mathrm{c}-50 \mu \mathrm{m}$, for $6,8,9 ; \mathrm{d}-100 \mu \mathrm{m}$, for 7,10 . 

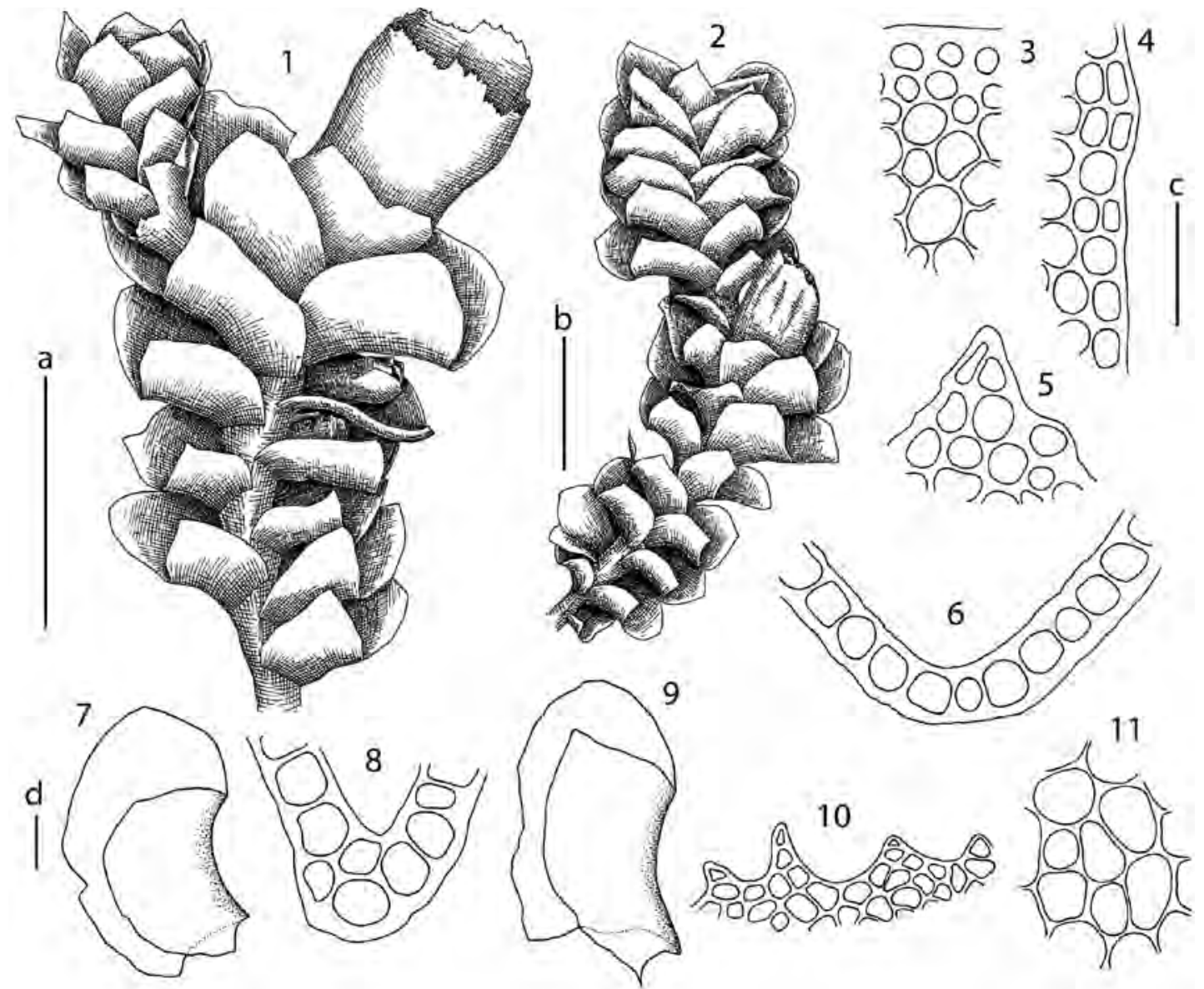

Figure 6 Scapania lingulata H. Buch. 1, 2 - perianthous plant, dorsal view; 3 - stem cross section, fragment; 4 - leaf margin; 5 - leaf apex; 6, 8 - keel cross section; 7, 9 - leaves; 10 - perianth mouth armature; 11 - midleaf cells. Scales: $\mathrm{a}-2 \mathrm{~mm}$, for $1 ; \mathrm{b}-2 \mathrm{~mm}$, for 2 ; $\mathrm{c}-50 \mu \mathrm{m}$, for $3-6,8,10,11 ; \mathrm{d}-200 \mu \mathrm{m}$, for 7,9 .

granulate. Specialized asexual reproduction by gemmae in masses at apices of leaf-lobes, elliptical, 14.0-19.6 × 11.2$14.0 \mu \mathrm{m}, 2$-celled, pale green. Sexual condition dioicous. Androecia intercalary, bracts in 2-4 pairs, similar to leaves, but inflated in the base, 4-6 androus, body ca. 140.0-160.0 $\times 160.0 \mu \mathrm{m}$, antheridial stalk 1-seriate, ca. $160.0-190.0 \mu \mathrm{m}$ long. Gynoecia terminal, bracts in one pair, slightly larger than sterile leaves, dorsal lobe $1.25-1.35 \times 0.75-0.85 \mathrm{~mm}$; ventral lobe $1.5-2.0 \times 1.0-1.5 \mathrm{~mm}$. Perianth oblong to obovate, dorsiventrally compressed, truncate, $2.5-3.0 \times 1.2-1.5$ $\mathrm{mm}$, mouth ciliate to lobulate, lobulae 2-6 cells long, 2-4 cells wide, some with additional cilia near base. Seta ca. 8.0-10.0 mm long. Capsule elliptic, ca. $250.0 \times 175.0 \mu \mathrm{m}$, 4-layered, inner cells 42.0-56.0 × 19.6-22.4 $\mu \mathrm{m}$, with annular thickenings, outer cells ca. $28.0-56.0 \times 28.0$ with $14-15$ nodular thickenings in each vertical wall. Elaters 2-spiral, ca. $140.0-160.0 \times 8.0-9.0 \mu \mathrm{m}$. Spores ca. $11.0-14.0 \mu \mathrm{m}$ in diameter, brown.

Habitat: Fine-grained soil along rivulets; wet finegrained soil in the cliff crevices; crumble slopes of pumice deposits; in different types of communities, but mostly coniferous forests and tundra; 15-1114 $\mathrm{m}$ alt.

Distribution: Primorsky Territory, Sakhalin Province, Kamchatka Territory, Magadan Province, Chukotka Province.
Specimens examined: PRIMORSKY TERRITORY, South of Sikhote-Alin Range, VB P-52-16-08 (VBGI); SAKHALIN PROVINCE, Shumshu Island, VB K-122-1-04 (VBGI), Iturup Island, VB K-58-24-05 (VBGI), VB K-67-3-05, K-67-4a-05, K-67-8a-05 (VBGI), VB K-71-6-05 (VBGI), Kunashir Island, VB K-38-5-06 (VBGI); KHABAROVSK TERRITORY, Okhotsk District, VB Kh-32-52-08 (VBGI), VB Kh-34-3-08 (VBGI); KAMCHATKA TERRITORY, Central Kamchatka, Esso Settl., VB K-112-5-03 (VBGI), Eastern Kamchatka, Ushkovsky volcano, VB K-52-5-03 (VBGI); MAGADAN PROVINCE, Magadan City area, VB Mag22-6-10, Mag-22-17-10, Mag-22-30-10, Mag-22-31-10, Mag-22-3510 (VBGI), Khasynsky District, VB Mag-9-6-10 (VBGI), Ol'sky District, O. Mochalova G106862 (KPABG, VBGI), Srednekansky District, VB Mag-15-9-10 (VBGI).

5. Scapania mucronata H. Buch, Meddeland. Soc. Fauna Fl. Fenn. 42: 91, 1916. (Fig. 7, 52: 15)

Description: Plants $5.0-10.0 \times 1.5-2.0 \mathrm{~mm}$, prostrate to ascending, green to greenish brown. Stems sparsely branched, dorsal surface greenish brown, ventral surface reddish brown to brown; cross section $0.26-0.27 \times 0.20-0.24 \mathrm{~mm}$, cortex cells thick-walled in one layer, 11.2-14.0 × 11.2-14.0 $\mu \mathrm{m}$, with brown walls; inner cells larger, thin-walled, 14.0 $22.4 \times 14.0-19.6 \mu \mathrm{m}$ with colorless walls. Rhizoids sparse to common, colorless to pale brown. Leaves contiguous; keel $0.5-0.6$ of ventral lobe length, straight to slightly arched, ca. $60-80^{\circ}$ with stem axis at the middle part and up to $110^{\circ}$ at the end; dorsal lobe transversely inserted, not decurrent, obliquely obovate, $0.75-1.00 \times 0.50-0.75 \mathrm{~mm}$, 


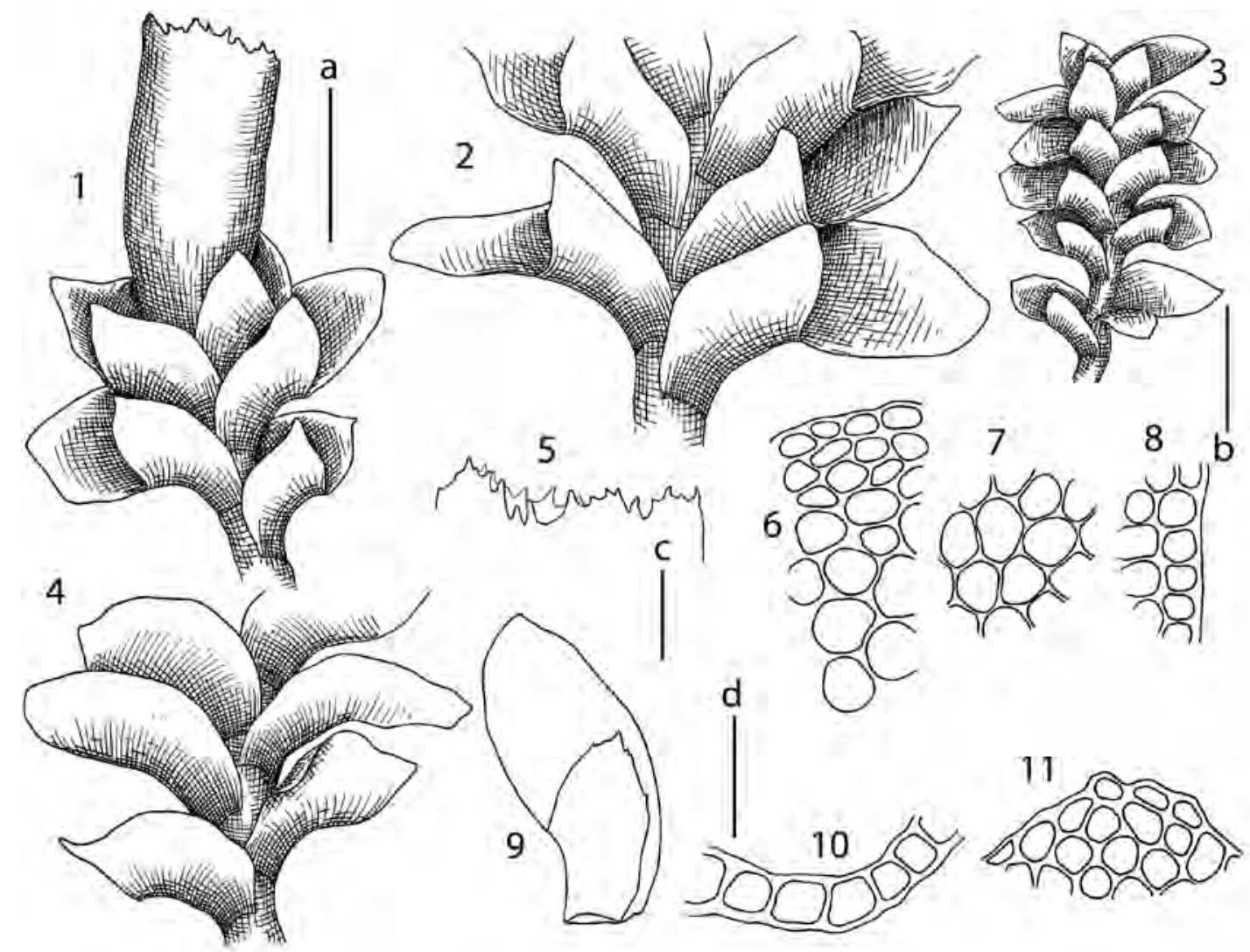

Figure 7 Scapania mucronata H. Buch. 1 - upper part of perianthous plant, dorsal view; 2 - part of shoot, dorsal view; 3 - habit, dorsal view; 4 - part of shoot, ventral view; 5 - perianth mouth armature; 6 - stem cross section, fragment; 7 - midleaf cells; 8 - leaf margin; 9 - leaf; 10 - keel cross section; 11 - leaf apex. Scales: a - $1 \mathrm{~mm}$, for 1, 2, 4; b - 1 $\mathrm{mm}$, for 3 ; $\mathrm{c}-200 \mu \mathrm{m}$, for 5 ; $\mathrm{d}-50 \mu \mathrm{m}$, for $6-8,10,11$.

$0.5-0.6$ of ventral in size, ca. $40-50^{\circ}$ with stem axis, margin entire, apex acute; ventral lobe transversely inserted, insertion line slightly arched, not decurrent, obliquely oblong to obovate, $1.00-1.50 \times 0.60-0.75 \mathrm{~mm},(0.5-0.6: 1)$, ca. $70-100^{\circ}$ with stem axis, margin entire, apex acute, apical tooth 1-2-celled. Cells in the midleaf oblong-rectangular, 14.0-28.0 × 14.0-22.4 $\mu \mathrm{m}$ with convex trigones; near apex $14.0-19.6 \times 14.0-19.6 \mu \mathrm{m}$ with triangular trigones, along margin thin-walled; at the base 28.0-47.6 × 22.4-28.0 $\mu \mathrm{m}$ with triangular trigones; cuticle weakly striolate. Oil bodies 4-6 per cells, spherical to shortly elliptical, 4.0-5.0 $\times 4.5$ $6.0 \mu \mathrm{m}$, finely granulate. Specialized asexual reproduction by gemmae in masses at apices of leaf-lobes, elliptical, 14.0-19.6 × 10.0-12.5 $\mu \mathrm{m}, 2$-celled, pale green. Sexual condition dioicous. Gynoecia terminal, bracts in one pair, slightly larger than sterile leaves, dorsal lobe 1.0-1.2 $\times$ 0.6-0.8 mm; ventral lobe $1.2-1.5 \times 0.6-0.8 \mathrm{~mm}$. Perianth oblong to obovate, dorsiventrally compressed, truncate, $1.5-2.0 \times 0.9-1.1 \mathrm{~mm}$, mouth ciliate to lobulate, lobulae 2-6 cells long, 1-4 cells wide, sometimes with additional cilia near base.

Habitat: Crevices in the gravelly barrens fields, sandy sliding slopes to the rivers in tundra communities; 500$1500 \mathrm{~m}$ alt.

Distribution: Magadan Province, Chukotka Province.

Specimens examined: MAGADAN PROVINCE, Khasynsky District, VB MAg-11-13-10 (VBGI), Srednekansky District, VB Mag-14-4-10 (VBGI).
Comment: The records of $S$. mucronata from Primorsky and Khabarovsky Province (Bakalin 2010) are based on misidentification of $S$. carinthiaca, and from Kamchatka Territory (Bakalin 2010) are based on misidentification of S. lingulata. Currently we were able to confirm it for Magadan Province only.

6. Scapania praetervisa Meyl., Jahresber. Naturf. Ges. Graubündens 64: 364, 1926 (Fig. 8, 52: 8)

Description: Plants $5.0-15.0 \times 1.5-2.5 \mathrm{~mm}$, ascending to erect, green to brownish green. Stems sparsely branched, dorsal surface greenish brown, ventral surface reddish brown to brown, cross section $0.20-0.23 \times 0.30-0.40 \mathrm{~mm}$, cortex cells thick-walled in one layer, $16.2-24.3 \times 13.0-16.2$ $\mu \mathrm{m}$, with brown walls; inner cells slightly larger, thin-walled, $16.2-27.5 \times 16.2-27.5 \mu \mathrm{m}$, with colorless walls. Rhizoids numerous, fasciculate, spreading at right angle with stem, colorless to pale brown. Leaves contiguous; keel 0.5-0.7 of ventral lobe length, straight to slightly arched, ca. $25-40^{\circ}$ with stem axis at the basal part and up to $70-90^{\circ}$ at the end; dorsal lobe transversely inserted, not decurrent, obliquely obovate, $0.62-0.87 \times 0.25-0.37 \mathrm{~mm}, 0.6-0.8$ of ventral in size, ca. $45-60^{\circ}$ with stem axis, margin entire, or sometimes denticulate to sparsely toothed near apex, apex acute; ventral lobe transversely inserted, insertion line slightly arched, not decurrent, obliquely oblong to obovate, $1.00-1.25 \times 0.50-0.62 \mathrm{~mm},(0.5-0.6: 1)$, ca. $60-80^{\circ}$ with stem axis, margin entire, sometimes denticulate to sparsely toothed near apex, apex obtuse to acute. Cells in the midleaf oblong-rectangular, $19.5-40.0 \times 16.2-26.0 \mu \mathrm{m}$ 


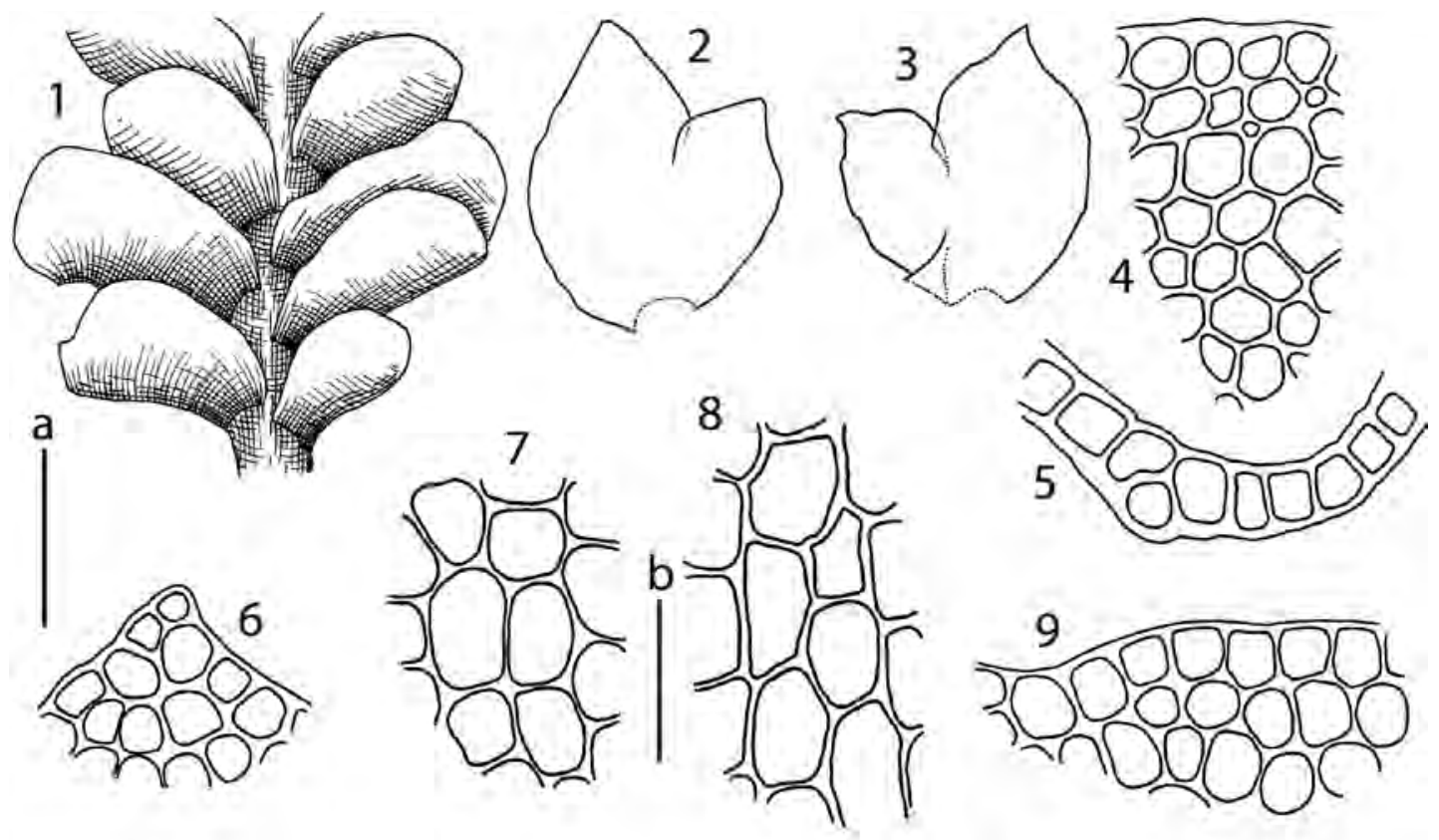

Figure 8 Scapania praetervisa Meyl. 1 - part of shoot, ventral view; 2, 3- leaves; 4 - stem cross section, 5 - keel cross section; 6 - lobe apex; 7 - midleaf cells; 8 - leaf base cells; 9 - leaf margin. Scales: $\mathrm{a}-500 \mu \mathrm{m}$, for $1-3$; b $-50 \mu \mathrm{m}$, for 4-9.

with triangular trigones; near apex (12.0-)14.5-(11.0-)17.8 $\times 16.2-21.1 \mu \mathrm{m}$ with triangular trigones, along margin thinwalled; at the base $25.0-48.6 \times 16.0-28.0 \mu \mathrm{m}$ with triangular trigones; cuticle weakly striolate. Specialized asexual reproduction by gemmae in masses at apices of leaf-lobes, elliptical, 24.3-32.4 × 13.0-16.2 $\mu \mathrm{m}$, 2-celled, pale green to reddish brown. Sexual condition dioicous. Androecia intercalary, bracts in 4-6 pairs, similar to leaves, but slightly inflated in the base, 3-androus, body ca. $160.0 \times 130.0 \mu \mathrm{m}$, stalk 1-seriate, ca. 60.0-100.0 $\mu \mathrm{m}$ long. Gynoecia terminal, bracts in one pair, slightly larger than sterile leaves, dorsal lobe $1.25-1.50 \times 0.75-1.00 \mathrm{~mm}$; ventral lobe $1.75-1.87 \times$ $1.00-1.25 \mathrm{~mm}$. Perianth oblong to obovate, weakly plicate, slightly dorsiventrally compressed, truncate, 1.00-1.25 $\times$ $0.50-0.75 \mathrm{~mm}$, mouth ciliate to lobulate, with lobulate 3-6 cells long, 2-4 cells wide.

Habitat: Peaty soil or over peat-moss mats in boggy areas in tundra zone; $18-1600 \mathrm{~m}$ alt.

Distribution: Chukotka Province (Afonina 2000); Kamchatka Province (Czernyadjeva et al. 2005).

[Specimens examined: MURMANSK PROVINCE, Kandalakshskij Bay of White Sea, N.A. Konstantinova 30.VII.1988 238/20 (KPABG, VBGI, JNU), N.A. Konstantinova 19.VIII.1991 201-5-91 (KPABG, VBGI, JNU), N.A. Konstantinova 16.VIII.1991 171-4-91 (KPABG, VBGI, JNU); REPUBLIC OF KARELIA, Kandalakshskij Bay of White Sea Krasnyj Island, N.A. Konstantinova 15.VIII.1989 205-5-89 (KPABG, VBGI, JNU), N.A. Konstantinova 12.VIII.1989 153-10-89 (KPABG, VBGI, JNU); SOUTH SIBERIA, Khamar-Daban Range, N.A. Konstantinova 04.VIII.2002 68-1-02 (KPABG, VBGI, JNU); CAUCASUS, REPUBLIC OF KARACHAEVO-CHERKESSIA, Teberda River Valley, N.A. Konstantinova 08.IX.2005 K551-3-05 (KPABG, VBGI, JNU).]

7. Scapania scandica (Arnell \& H.Buch) Macvicar, Stud. Handb. Brit. Hepat. (ed. 2) 394, 1926. (Fig. 9, 52: 7)

Description: Plants $7.0-10.0 \times 1.7-2.5 \mathrm{~mm}$, prostrate to ascending, green to reddish brown in full sun. Stems sparsely branched, dorsal surface pale reddish brown, ventral surface deep reddish; cross section 0.26-0.30 $\times 0.18-0.23 \mathrm{~mm}$, cortex cells thick-walled in one layer, $14.0-19.0 \times 11.2-14.0 \mu \mathrm{m}$, with reddish brown walls; inner cells larger, thin-walled, 19.6-28.0 × 19.6-28.0 $\mu \mathrm{m}$, with colorless walls. Rhizoids sparse to common, colorless to pale brown. Leaves contiguous; keel $0.45-0.55$ of ventral lobe length, straight to slightly arched, ca. $30-50^{\circ}$ with stem axis at the middle part and up to $90-110^{\circ}$ at the end; dorsal lobe transversely inserted, not decurrent, obliquely obovate, $0.50-1.00 \times 0.35-0.50 \mathrm{~mm}, 0.5-0.6$ of ventral in size, ca. $30-50^{\circ}$ with stem axis, margin entire to denticulate, apex acute, apical tooth 1-3-celled; ventral lobe transversely inserted, insertion line slightly arched, not decurrent, obliquely oblong to obovate, $1.00-1.50 \times 0.60-0.75 \mathrm{~mm}$, (0.55-0.60 : 1), ca. $50-90^{\circ}$ with stem axis, margin entire to, sometimes, sparsely denticulate, apex rounded to acute, apical tooth 1-2 celled. Cells in the midleaf polygonal, $12.0-33.6 \times 12.0-28.0 \mu \mathrm{m}$ with triangular trigones; near apex 12.0-22.4 × 11.0-19.6 $\mu \mathrm{m}$, along margin thin-walled; at the base $20.0-42.0 \times 11.8-28.0 \mu \mathrm{m}$ with triangular trigones; cuticle smooth to weakly striolate. Specialized asexual reproduction by gemmae in masses at apices of leaf-lobes, elliptical, 14.0-19.6 × 8.4-11.2 $\mu \mathrm{m}$, 2-celled, pale green. Sexual condition dioicous. Gynoecia terminal, bracts in one pair, slightly larger than sterile leaves, dorsal lobe $0.75-1.00 \times 0.50-0.75 \mathrm{~mm}$; ventral lobe $1.50-1.75 \times$ $0.75-1.00 \mathrm{~mm}$. Perianth oblong to obovate, weakly plicate, truncate, $1.25-1.50 \times 1.75-1.00 \mathrm{~mm}$, mouth entire to denticulate.

Habitat: Peaty soil or over peat-moss in peatlands in tundra zone or belt; fine-grained soil in roadsides in coniferous forests; 68-500 m alt.

Distribution: Sakhalin Province, Kamchatka Territory, Magadan Province, Chukotka Province. 


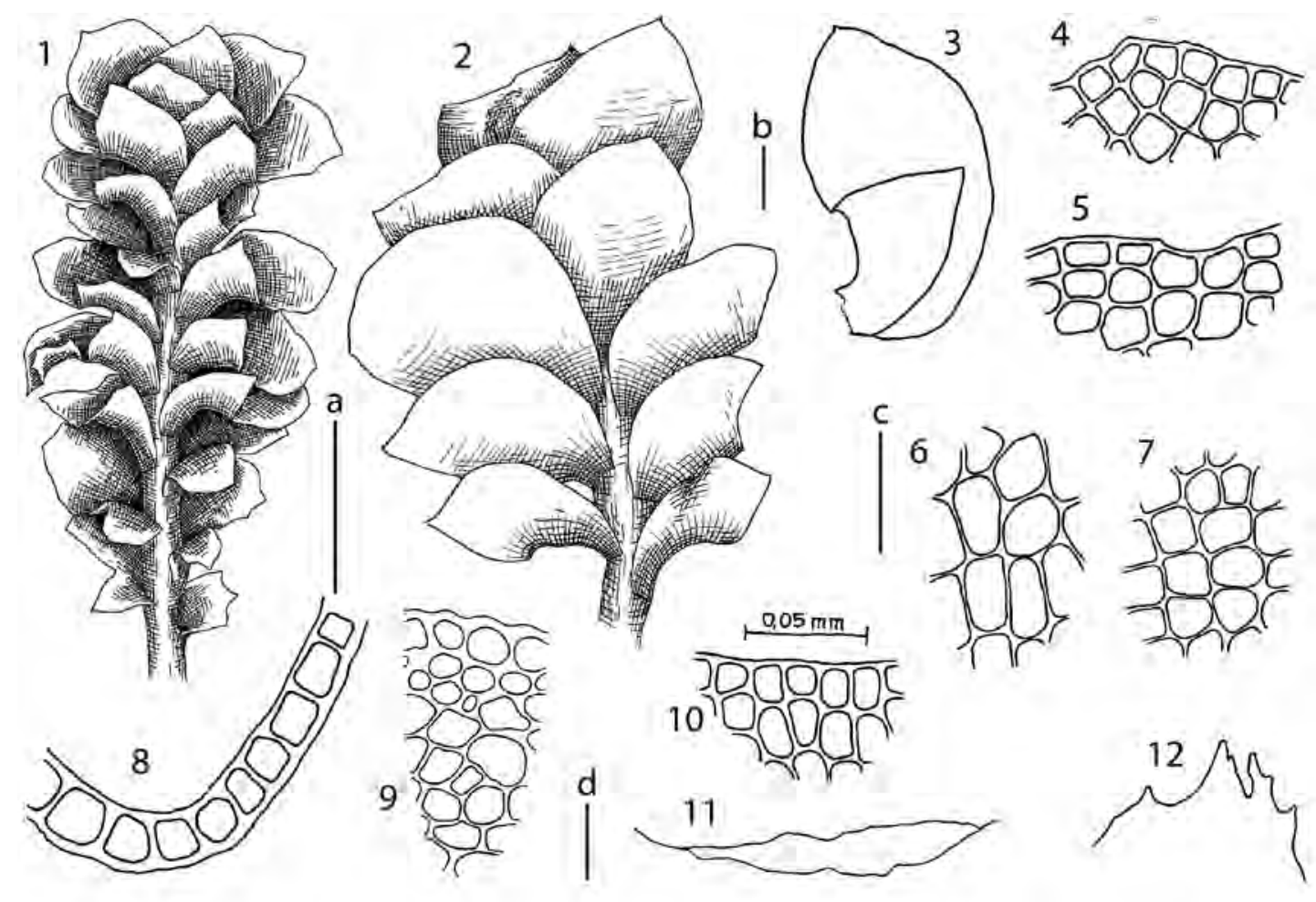

Figure 9 Scapania scandica (Arnell \& H. Buch) Macvicar 1 - habit, dorsal view; 2 - habit, ventral view; 3 - leaf; 4, 12 leaf apex; 5, 10 - perianth mouth; 6 - leaf base cells; 7 - midleaf cells; 8 - keel cross section; 9 - stem cross section, fragment; 11 - perianth cross section. Scales: $\mathrm{a}-1 \mathrm{~mm}$, for 1,$2 ; \mathrm{b}-200 \mu \mathrm{m}$, for 3 ; $\mathrm{c}-50 \mu \mathrm{m}$, for $4-10$; $\mathrm{d}-100 \mu \mathrm{m}$, for 11 ; e $-200 \mu \mathrm{m}$, for 12 .

Comment: The records of S. scandica from Primorsky and Khabarovsk Territories (Bakalin 2010) are based on misidentification of S. carinthiaca.

Specimens examined: SAKHALIN PROVINCE, Sakhalin Island, Due (Dui) Bay, VB S-59-22-09 (VBGI), Pilenga River, VB S-29-6-09 (VBGI), Belaya River, VB S-25-25a-06 (VBGI).

8. Scapania obcordata (Berggr.) S.W. Arnell, Ark. Bot., n.s., 4(6): 117, 1959 (Fig. 10, 52: 14)

Description: Plants $5.0-15.0 \times 1.0-2.0 \mathrm{~mm}$, prostrate to ascending, brownish green to brownish violet and brownish purple to reddish brown. Stems sparsely branched, dorsal surface brownish green to brownish purple, ventral surface reddish brown to deep brown, cross section $0.15-0.25 \times$ $0.22-0.33 \mathrm{~mm}$, cortex cells thick-walled in 1(-2) layer, 11.0 $16.2 \times 11.3-16.2 \mu \mathrm{m}$ with brown walls; inner cells larger, thin-walled, 16.2-24.3 $\times 13.0-19.5 \mu \mathrm{m}$ with colorless walls. Rhizoids common, isolate, spreading at right angle with stem, colorless. Leaves contiguous; keel (or undivided leaf lamina, if no keel) (0.45-) $0.50-0.75$ of ventral lobe length, straight to slightly arched, ca. $30-45^{\circ}$ with stem axis at the basal part and up to $90-100^{\circ}$ at the end; dorsal lobe transversely inserted, not decurrent, ovate to obliquely obovate, convex, $0.37-0.63 \times 0.25-0.35 \mathrm{~mm}, 0.55-0.85$ of ventral in size, ca. $40-60^{\circ}$ with stem axis, margin entire, apex rounded to obtuse; ventral lobe transversely inserted, insertion line slightly arched, not decurrent, obliquely oblong to obovate, concave, $0.50-1.00 \times 0.50-0.75 \mathrm{~mm}$, (0.6-0.8: 1), ca. $50-80^{\circ}$ with stem axis, margin entire, apex rounded to obtuse. Cells in the midleaf oblong, 15.5-24.3 $\times 14.2-19.5 \mu \mathrm{m}$ with concave to triangular trigones; near apex 11.0-21.1 $\times 10.0-22.7 \mu \mathrm{m}$ with triangular trigones; along margin thin-walled; at the base $24.3-32.4 \times 16.2-24.3$ $\mu \mathrm{m}$ with concave to triangular trigones; cuticle weakly striolate. Specialized asexual reproduction by gemmae in masses at apices of shoots, broadly ovate to elliptical, $16.2-24.3 \times 11.3-16.2 \mu \mathrm{m},(1-) 2$-celled, pale green. Sexual condition dioicous. Androecia intercalary, bracts in $3-5$ pairs, similar to leaves, but strongly inflated in the base, 1-3 androus, body ca. $130.0 \times 100.0 \mu \mathrm{m}$, antheridial stalk 1-seriate, ca. 70.0-100.0 $\mu \mathrm{m}$ long. Gynoecia terminal, bracts in one pair, slightly larger than sterile leaves, dorsal lobe $0.45-0.75 \times 0.30-0.55 \mathrm{~mm}$; ventral lobe 0.75-1.15 $\times 0.65-0.85 \mathrm{~mm}$. Perianth oblong to obovate, weakly dorsiventrally compressed, truncate, $1.00-1.25 \times 0.75-1.00$ $\mathrm{mm}$, mouth denticulate.

Habitat: peaty soil or over peat-moss in peatlands in tundra zone and belt; 115-399 m alt.

Distribution: Kamchatka Territory, Magadan Province, Chukotka Province.

Comment. S. obcordata was previously placed in sect. Jensenia (Schuster 1974, Schliakov 1980). Later this species was transferred to sect. Curtae (Potemkin 1998, 2002). The main reason for separating of sect. Jensenia was a loosely keeled leaves, a feature that is very unstable in S. obcordata since robust forms of the species commonly have well developed keel. On the other hand, the characters of 1) green, 2-celled gemmae, and 2) 1(-2) lavers thick-walled cells along margin in stem cross section refer this species to sect. Curtae. The molecular researches support the same (Vilnet et al. 2010).

Specimens examined: KHABAROVSK TERRITORY, Okhotsk District, VB Kh-25-18-08 (VBGI), VB Kh-34-9-08, Kh-34-12-08 (VBGI); [MURMANSK PROVINCE, Kandalakshskij Bay of White Sea, N.A. Konstantinova 19VIII.1991 201-5-91 (KPABG, VBGI).] 

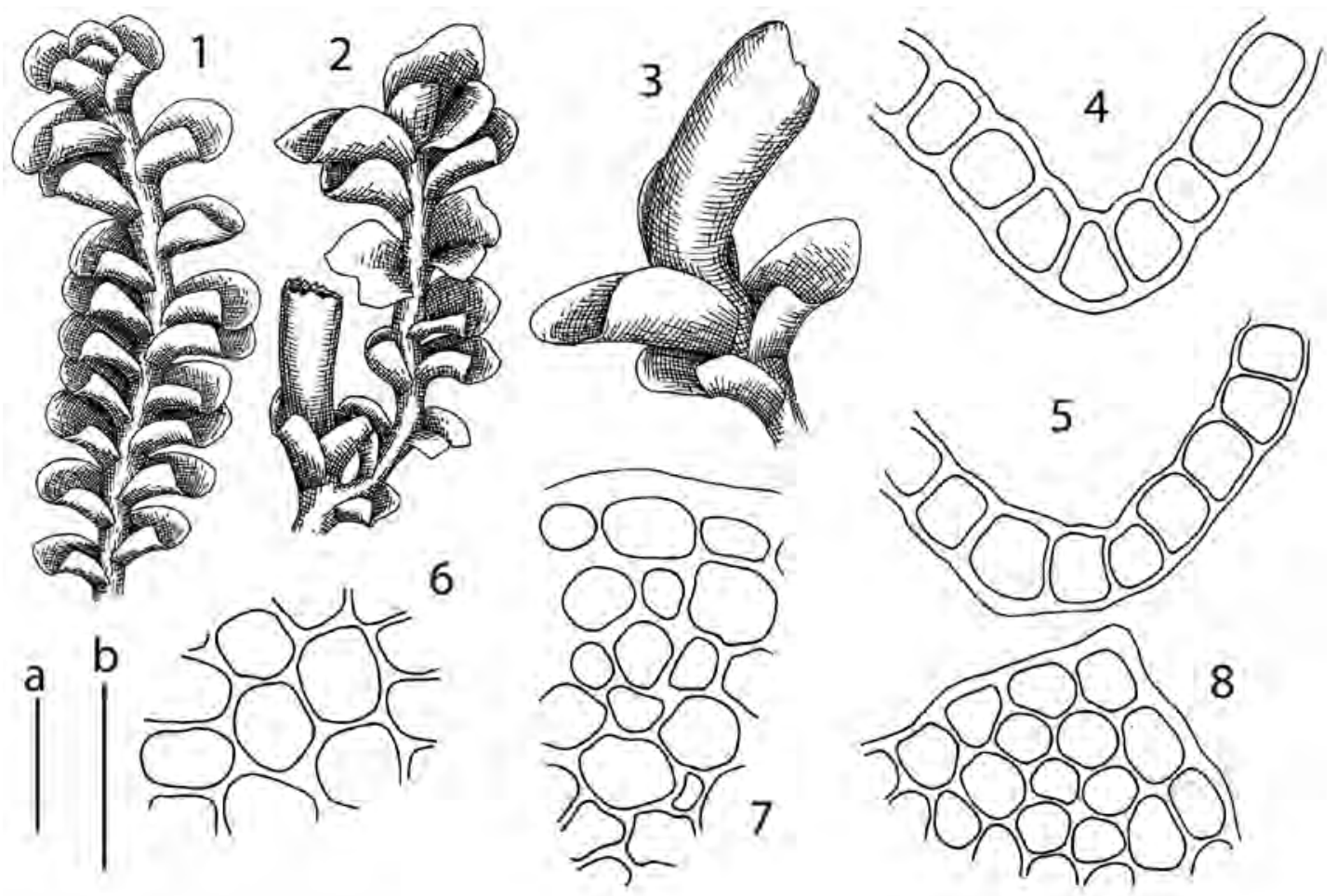

Figure 10 Scapania obcordata (Berggr.) S.W. Arnell. 1 - habit, dorsal view; 2 - perianthous plant, dorsal view; 3 - upper part of perianthous plant, dorsal view; 4, 5 - keel cross section; 6 - midleaf cells; 7 - stem cross section; 8 - leaf apex. Scales: $\mathrm{a}-1 \mathrm{~mm}$, for $1-3 ; \mathrm{b}-50 \mu \mathrm{m}$, for $4-8$.

9. Scapania irrigua (Nees) Dumort., Syn. Hepat. 67, 1844. (Fig. 11)

Description: Plants $10.0-30.0 \times 2.0-3.0 \mathrm{~mm}$, ascending to erect, yellowish green to brownish green. Stems sparsely branched, pale brownish near apex, brown below, cross section $0.25-0.30 \times 0.30-0.37 \mathrm{~mm}$, cortex cells thick-walled in $1-2$ layers, $14.0-19.6 \times 8.4-14.0 \mu \mathrm{m}$ with brown walls; inner cells larger, thin-walled, $22.4-36.4 \times 16.8-28.0 \mu \mathrm{m}$ with colorless walls. Rhizoids common to numerous, fasciculate, spreading at right angle with stem, colorless. Leaves contiguous; keel $0.25-0.50$ of ventral lobe length, usually $1-3$ cells lamellatewinged, slightly to strongly arched, ca. $30-60^{\circ}$ with stem axis at the base and gradually incurved up to $110-135^{\circ}$ at the end; dorsal lobe transversely inserted, not decurrent, broadly obliquely subrectangular to obovate, arching over stem and beyond stem, slightly convex $0.75-1.25 \times 0.50-1.00 \mathrm{~mm}$, $0.5-0.6$ of ventral in size, ca. $30-60^{\circ}$ with stem axis, margin entire, apex obtuse to acute; ventral lobe transversely inserted, insertion line distinctly arched, not or sometimes slightly decurrent, rounded to obliquely obovate, $1.15-2.00 \times 1.15-$ $1.50 \mathrm{~mm},(0.75-1.00: 1)$, ca $50^{\circ}-70^{\circ}$ with stem axis, margin entire, apex obtuse to acute. Cells in the midleaf oblong, 28.0-36.4 $\times 22.4-28.0 \mu \mathrm{m}$ with triangular trigones; near apex rectangular, $10.2-19.6 \times 10.0-22.4 \mu \mathrm{m}$ with triangular trigones; at the base $30.0-56.0 \times 18.4-28.0 \mu \mathrm{m}$ with triangular trigones; cuticle smooth to slightly papillose or verrucose. Oil bodies $4-6$ per cells, granulate, irregularly ovate, $4.5-6.0 \times$ $5.0-7.0 \mu \mathrm{m}$. Specialized asexual reproduction by gemmae in masses at apices of shoots, narrowly elliptical, 19.6-22.4 $\times$ 8.4-11.2 $\mu \mathrm{m}, 2$-celled, pale green. Sexual condition dioicous. Gynoecia terminal, bracts in one pair, slightly larger than sterile leaves, dorsal lobe 1.15-1.50 × 1.25-1.50 mm; ventral lobe $2.00-2.25 \times 1.50-1.75 \mathrm{~mm}$. Perianth oblong to obovate, dorsiventrally compressed, truncate, $2.00-2.25 \times 1.25-1.50$ $\mathrm{mm}$, mouth entire to denticulate. Seta ca. $10.0 \mathrm{~mm}$ long. Capsule elliptic, ca. $1000.0 \times 750.0 \mu \mathrm{m}, 5-6$ layered, inner cells $42.0-56.0 \times 22.4-28.0 \mu \mathrm{m}$, with annular thickenings, outer cells ca. $28.0-42.0 \times 22.4-28.0$ with $20-21$ nodular thickenings in each vertical wall. Elaters 2-spiral, ca. 100.0 $160.0 \times 8.4-10.0 \mu \mathrm{m}$, deep brown. Spores ca. $11.2-14.0 \mu \mathrm{m}$ in diameter, brown.

Habitat: humus and rocks near stream in dark coniferous forests and peaty soil or over peat-moss in peatlands in tundra zone and belt; $2-1453 \mathrm{~m}$ alt.

Distribution: Primorsky Territory, Khabarosk Territory, Sakhalin Province, Kamchatka Territory, Magadan Province, Chukotka Province.

Comment: S. irrigua was previously placed in sect. Irriguae (Buch 1927, Schuster 1974, Potemkin 2002). Since then, this species was transferred to sect. Curtae based on molecular data (Vilnet et al. 2010; Heinrichs et al. 2012). The characters of green, 2-celled gemmae and 1(-2) layers of thick-walled cells along margin in stem cross section suggest the same.

Specimens examined: PRIMORSKY TERRITORY, Yasnaya River, S.K. Gambaryan 09.VI.1994 VLA-h2474 (VLA). SAKHALIN PROVINCE, Paramushir Island, VB K-82-1604 (KPABG, VBGI), VB K-77-6-04 (VBGI), VB K-89-3-04 (KPABG, VBGI), Iturup Island, VB K-14-1-07 (VBGI), VB K-19-8-07 (VBGI), VB K-49-4-05 (VBGI), VB K-67-2-05, K-679-05 (VBGI), Sakhalin Island, Nabil'sky Range, M.S. Ignatov 17.VIII.2006 G13 (VBGI), Pilenga River, VB S-29-25-09 (VBGI), Pomr' Bay, VB S-33-2-09, S-33-5-09, S-33-8-09 (VBGI), Korsakovsky District, VB S-66-14-09 (VBGI); KHABAROVSK TERRITORY, Solnechnyj District, VB Kh-5-38-07 (VBGI), VB Kh6-18-07 (VBGI), Okhotsk District, VB Kh-23-15-08 (VBGI), VB Kh-28-9-08 (VBGI), VB Kh-39-4-08, Kh-41-4-08 (VBGI); KAMCHATKA TERRITORY, Central Kamchatka, Esso Settl. area, VB K-137-12-04 (VBGI), Eastern Kamchatka, Kronotsky State 

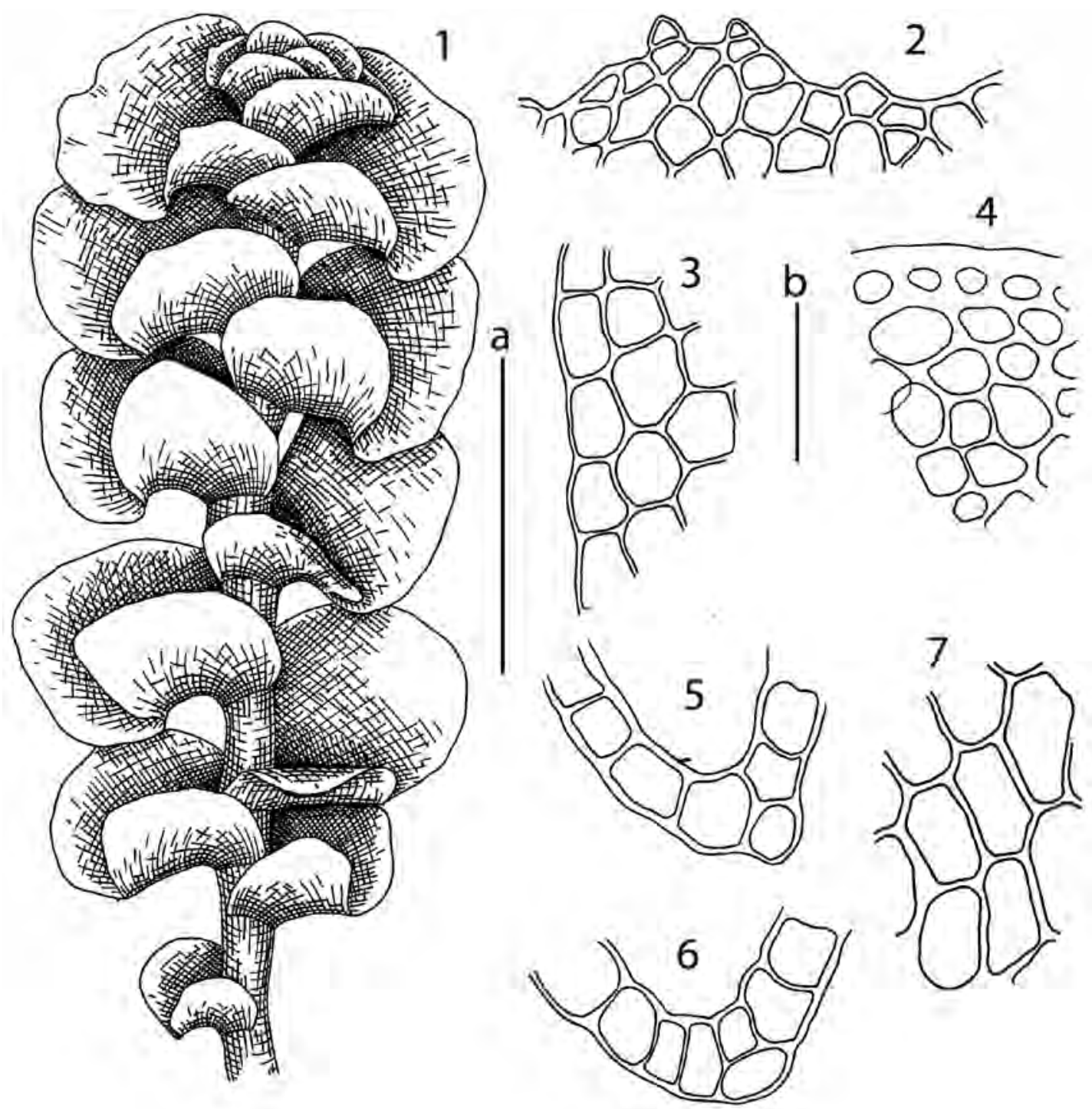

Figure 11 Scapania irrigua (Nees) Dumort. 1 - habit, dorsal view; 2 - leaf apex; 3 - leaf margin; 4 - stem cross section, fragment; 5,6 - keel cross section; 7 - midleaf cells. Scales a $-2 \mathrm{~mm}$, for $1 ; \mathrm{b}-50 \mu \mathrm{m}$, for $2-7$.

Reserve, O.A. Chernyagina (VBGI), Petropavlovsk-Kamchatsky City, VB K-21-3-04 (VBGI), Utegnyk Mt., VB K-27-3-03 (VBGI), Pushchino Settl., I.V. Czernyadjeva 02.VIII.2004 (VBGI); MAGADAN PROVINCE, Magadan City area, VB Mag-19-3-10, Mag-19-5-10, Mag-22-8-10 (VBGI), Srednekansky District, VB Mag-15-16-10, Mag-15-17-10 (VBGI).

10. Scapania magadanica. S.S. Choi, Bakalin \& B.-Y. Sun sp.nov. (Fig. 12)

Holotypus: Russia, Magadan Province, Magadan city area, Marchekanskaya Mt. (N59³0’49” E 15049’51”), 621 $\mathrm{m}$ alt. Shaded rocks in stony field near Pinus pumila crooked forest. Leg. 15 Aug. 2011 S.S. Choi and V. Bakalin R6581 (holotypus in JNU, isotypus in VLA)

Description: Plants 10.0-20.0 × 2.5-3.2 mm, prostrate, deep green to brownish green and olive-green. Stems sparsely branched, pale brownish green near apex, deep brown below, cross section $0.25-0.30 \times 0.37-0.42 \mathrm{~mm}$, cortex cells thick-walled in 1-2 layers, $11.2-14.0 \times 11.2-14.0 \mu \mathrm{m}$ with brown walls; inner cells larger, thin-walled, 14.0-28.0 $\times 14.0-28.0 \mu \mathrm{m}$ with colorless walls. Rhizoids common to numerous, fasciculate, spreading at right angle with stem, colorless. Leaves densely imbricate; keel $0.5-0.6$ of ventral lobe length, straight, ca. $70-90^{\circ}$ with stem axis, usually with wing 2-3 cells wide; dorsal lobe transversely inserted, not decurrent, obliquely rectangular to obovate, slightly convex, $1.00-1.25 \times 0.50-0.75 \mathrm{~mm}, 0.6-0.8$ of ventral in size, ca. $45-60^{\circ}$ with stem axis, margin entire, apex rounded to obtuse; ventral lobe transversely inserted, insertion line slightly arched, not decurrent, slightly convex, obliquely oblong, $1.50-1.75 \times 1.00-1.15 \mathrm{~mm},(0.60-0.65: 1)$, ca. $70-90^{\circ}$ with stem axis, margin entire to sometimes distantly denticulate, apex rounded. Cells in the midleaf oblong to polygonal,(12.0-)24.0-33.6 × (12.0-)16.8-22.4 $\mu \mathrm{m}$ with concave to triangular trigones; near apex (11.0-)14.0-19.6 $\times(10.0-) 16.8-28.0 \mu \mathrm{m}$, thin-walled; at the base 28.0-42.0 $\times$ 19.6-22.4 $\mu \mathrm{m}$ with concave trigones; cuticle smooth to slightly striolate. Oil bodies 3-6 per cell, spherical to elliptical, granulate, 3.5-8.4 × 3.5-4.5 $\mu \mathrm{m}$. Specialized asexual reproduction by gemmae in masses at apices of leaf-lobes, elliptical, 19.6-25.2 × 14.0-16.8 $\mu \mathrm{m}, 2$-celled, green. Sexual condition paroicous. Androecia just below female bracts, in 1-2 pairs of leaves, similar to leaves but inflated in the base, $3-5$ androus, body ca. $100 \times 80 \mu \mathrm{m}$, 

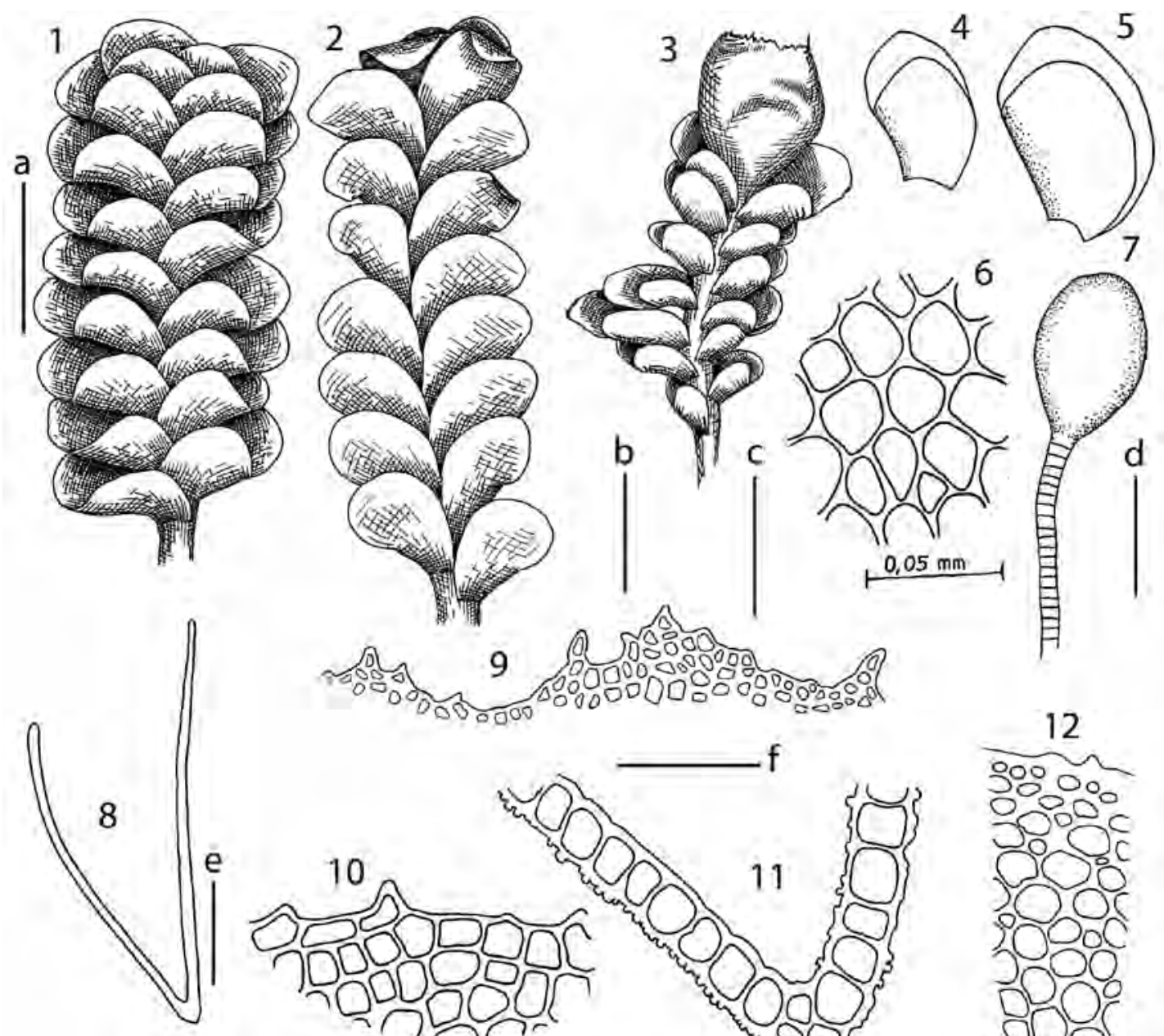

12

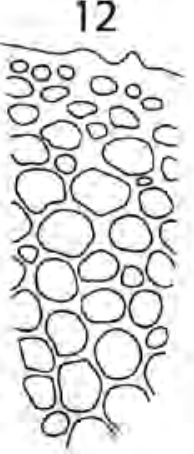

Figure 12 Scapania magadanica. S. S. Choi, V. A. Bakalin \& B.-Y. Sun 1 - habit, dorsal view; 2 - habit, ventral view; 3 perianthous plant, dorsal view; 4, 5 - leaves; 6 - midleaf cells; 7 - antheridium; 8 - leaf cross section; 9 - perianth mouth armature; 10 - leaf margin; 11 - keel cross section; 12 - stem cross section, fragment. Scales: $\mathrm{a}-2 \mathrm{~mm}$, for $1-3 ; \mathrm{b}-1 \mathrm{~mm}$, for 4,$5 ; \mathrm{c}-50 \mu \mathrm{m}$, for $6,10-12 ; \mathrm{d}-100 \mu \mathrm{m}$, for 7 ; e $-200 \mu \mathrm{m}$, for 8 .

antheridial stalk 1-seriate, ca. 80.0-140.0 $\mu \mathrm{m}$ long. Perianth oblong to obovate, dorsiventrally compressed, truncate, 2.0-2.5 $\times 1.5-1.7 \mathrm{~mm}$, mouth dentate to ciliate. Seta ca. 4.0-6.0 mm long. Capsule elliptic, ca. $1250.0 \times 800.0-$ $900.0 \mu \mathrm{m}$, 4-layered, inner cells 42.0-70.0 × 22.4-33.6 $\mu \mathrm{m}$, with annular thickenings, outer cells ca. 56.0-84.0 $\times$ 28.0-42.0 with 14-16 nodular thickenings in vertical wall. Elaters 2-spiral, ca. $140.0-160.0 \times 6.0-8.4 \mu \mathrm{m}$. Spores ca. $14.0-19.6 \mu \mathrm{m}$ in diameter, papillose, brown.

Habitat: Shaded rocks in stony fields near Pinus pumila crooked forest; 300-621 m alt.

Distribution: Magadan Province.

Comment: The striking characteristics of the new species are green to colorless green 2-celled elliptical gemmae, rounded apex of dorsal lobe, not decurrent ventral lobe, paroicous sexual condition - a combination is not present in other members of the genus.

Within section Curtae, S. magadanica seems to be most morphologically similar to $S$. diplophylloides in rounded apex of dorsal and ventral lobes. However, new species differs from the latter in a) thin-walled marginal cells of ventral lobe versus equally thickwalled, b) paroicous inflorescence versus dioicous, c) usually entire ventral lobe margin versus denticulate ventral lobe margin, d) brownish green to olive-green pigmentation.

Additional specimens examined: MAGADAN PROVINCE,
Magadan City area, VB Mag-19-4-10, Mag-19-6-10 (VBGI, JNU), S.S. Choi and VB 15.VIII.2011 R6581 (JNU).

SCAPANLA SECT. STEPHANLA Amak. et S. Hatt., J. Hattori Bot. Lab. 12: 94, 1954.

Description: Plants 10.0-30.0 × 1.0-3.6 mm, ascending to erect, yellowish green to brownish green sometimes tinged with red. Stems sparsely branched, yellowish green near apex and brownish to fuscous brown below, cross section 0.2-0.3 $\times 0.1-0.3 \mathrm{~mm}$, cortex cells strongly thick-walled in $2-5$ layers. Rhizoids sparse to common, isolate to fasciculate, spreading at right angle with stem, colorless. Leaves contiguous to imbricate; keel $0.3-0.6$ of ventral lobe length, usually winged, commonly straight to slightly arched, ca. $50-80^{\circ}$ with stem axis at the base part and gradually incurved up to $80-120^{\circ}$ at the end; dorsal lobe transversely inserted, insertion line slightly arched, not decurrent, obliquely rectangular to ovate, flat to slightly convex, arching over stem and farther beyond stem, $0.5-0.9$ of ventral in size, ca. $40^{\circ}-60^{\circ}$ with stem axis, margin denticulate to dentate, apex rounded to acute; ventral lobe insertion line arched, slightly decurrent for $0.3-0.5$ of stem width, obliquely oblong, obovate to rounded, flat to convex, ca. $60-80^{\circ}$ with stem axis, margin recurved, denticulate to dentate, apex rounded to acute; cells in the 
Table 2. Comparison of Species of Scapania sect. Stephania and One Related Species (S. ampliata) From sect. Nemorosae

\begin{tabular}{|c|c|c|c|c|c|c|}
\hline Characters & S. hirosakiensis & S.parvidens & S. parvitexta & $\begin{array}{l}\text { [S. integerrima, } \\
\text { fig. } 13]\end{array}$ & [S. ligulata, fig. 14] & [S. ampliata $]$ \\
\hline Cuticle & $\begin{array}{l}\text { strongly } \\
\text { papillose }\end{array}$ & striolate & $\begin{array}{c}\text { weakly striolate to } \\
\text { verrucose }\end{array}$ & $\begin{array}{c}\text { smooth to weakly } \\
\text { verrucose }\end{array}$ & $\begin{array}{c}\text { smooth to weakly } \\
\text { verrucose }\end{array}$ & $\begin{array}{c}\text { weakly striolate to } \\
\text { verrucose }\end{array}$ \\
\hline $\begin{array}{l}\text { ed cell rows } \\
\text { sin in stem } \\
\text { on }\end{array}$ & $3-4$ & $2-4(-5)$ & $2-3(-5)$ & $2-3$ & $3-5$ & $3-4$ \\
\hline $\begin{array}{l}\text { Dorsal lobe of ventral } \\
\text { lobe size }\end{array}$ & 0.40 & $0.70-0.80$ & $0.60-0.70$ & $0.35-0.50$ & $0.50-0.60$ & 0.50 \\
\hline Ventral lobe & $\begin{array}{c}\text { rounded- } \\
\text { obovate }\end{array}$ & rounded-obovate & rounded-obovate & oblong-obovate & oblong-obovate & obliquely ovate \\
\hline Ventral lobe as w & $0.70-0.80$ & $075-100$ & $0.70-0.90$ & $0.50-0.60$ & $0.40-0.66$ & $0.65-0.75$ \\
\hline $\begin{array}{l}\text { Keel length of ventral } \\
\text { lobe }\end{array}$ & $0.30-0.45$ & $0.50-0.60$ & $0.40-0.50$ & $0.20-0.30$ & $0.25-0.35$ & $0.30-0.45$ \\
\hline Apex of ventral lobe & obtuse & rounded to obtuse & rounded to obtuse & acute & rounded to obtuse & acute \\
\hline $\begin{array}{l}\text { Decurrency of dorsal } \\
\text { lobe }\end{array}$ & not decurrent & not d & not decurrent & not decurrent & not decurrent & decurrent \\
\hline Gemmae & $\begin{array}{c}\text { green, } \\
\text { 1-celleed }\end{array}$ & $\begin{array}{l}\text { green to yellowish } \\
\text { brown, 1-celled }\end{array}$ & $\begin{array}{l}\text { green } \\
\text { 1-celled }\end{array}$ & $\begin{array}{l}\text { green, } \\
\text { 1-celled }\end{array}$ & $\begin{array}{l}\text { green, } \\
\text { 1-celled }\end{array}$ & $\begin{array}{l}\text { yellowish brown, } \\
\text { 1-celled }\end{array}$ \\
\hline Habitat (in general) & decaying wood & $\begin{array}{l}\text { wet rocks covered } \\
\text { thin soil }\end{array}$ & $\begin{array}{c}\text { wet rocks covered } \\
\text { thin soil }\end{array}$ & $\begin{array}{c}\text { wet rocks covered } \\
\text { thin soil }\end{array}$ & $\begin{array}{c}\text { wet rocks covered } \\
\text { thin soil }\end{array}$ & $\begin{array}{l}\text { humus or crevices } \\
\text { in rocks }\end{array}$ \\
\hline
\end{tabular}
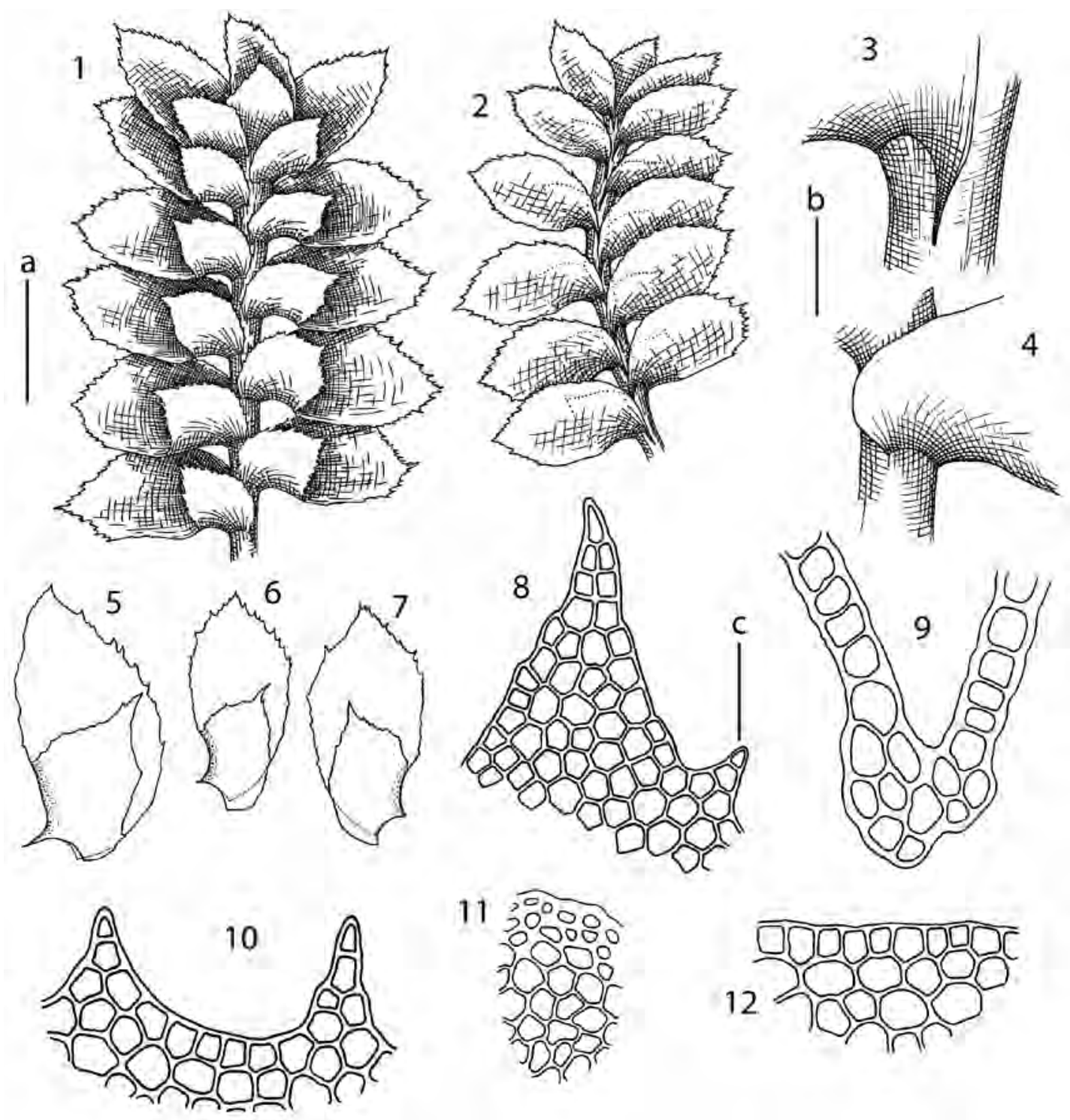

Figure 13 Scapania integerrima Steph. 1 - habit, dorsal view; 2 - habit, ventral view; 3 - leaf insertion, ventral view; 4 - leaf insertion, ventral view; 5-7 - leaves; 8 - leaf apex; 9 - keel cross section; 10, 12 - leaf margin; 11 - stem cross section, fragment. Scales: $\mathrm{a}-500 \mu \mathrm{m}$, for 1,$2 ; \mathrm{b}-200 \mu \mathrm{m}$, for 3, 4; $-50 \mu \mathrm{m}$, for 8-12. 

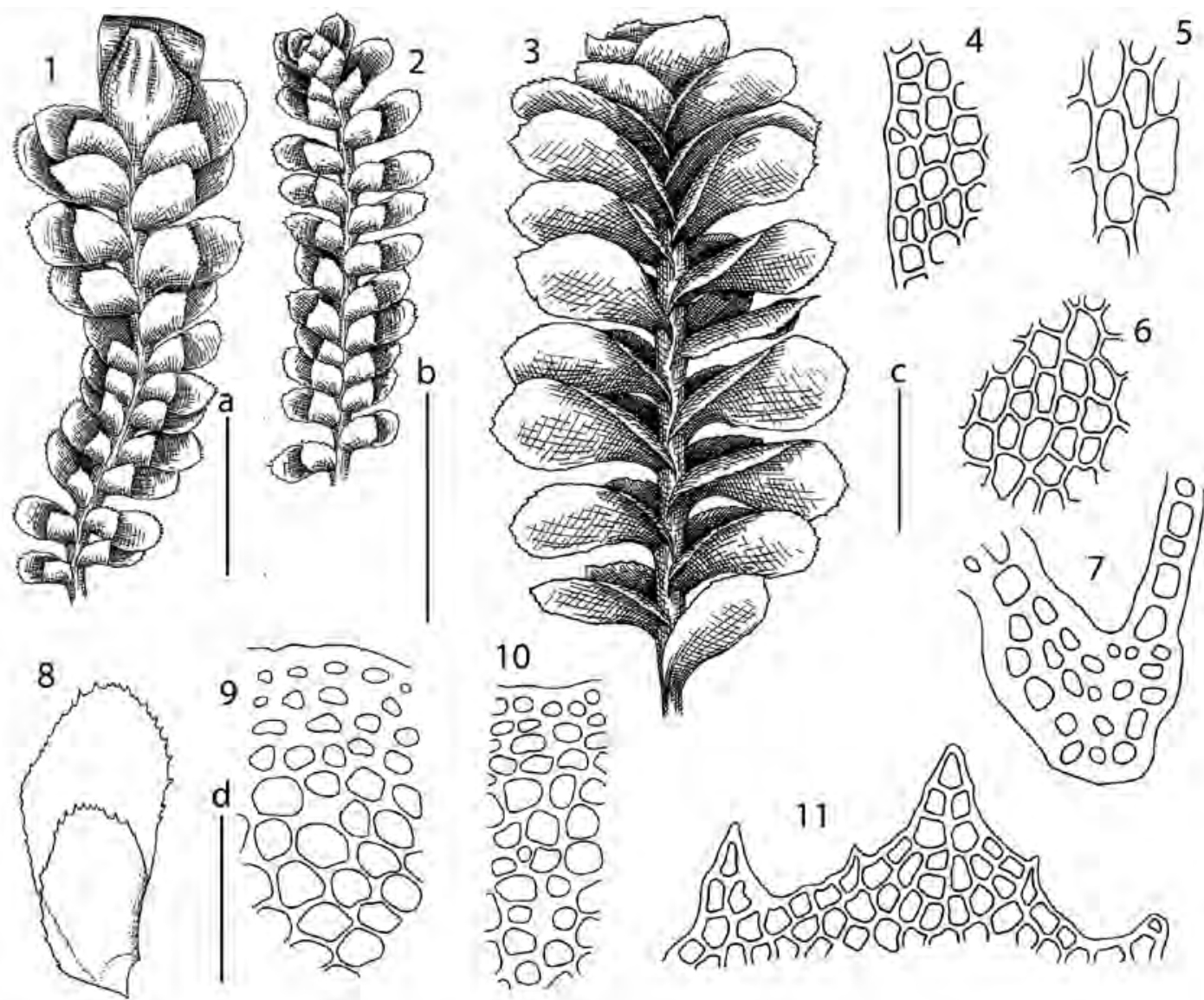

Figure 14 Scapania ligulata Steph. 1 - perianthous plant, dorsal view; 2 - habit-dorsal view; 3 - habit, ventral view; 4 - leaf margin; 5 - leaf base cells; 6 - midleaf cells; 7 - keel cross section; 8 - leaf; 9,10 - stem cross section, fragment; 11 - leaf apex. Scales: $\mathrm{a}-1 \mathrm{~mm}$, for 1,$2 ; \mathrm{b}-1 \mathrm{~mm}$, for 3 ; c $-50 \mu \mathrm{m}$, for $4-7,9-11$; d $-500 \mu \mathrm{m}$, for 8 .

midleaf thick-walled, with triangular to convex trigones; near apex equally thick-walled; cuticle smooth to verrucose or papillose. Specialized asexual reproduction by green to yellowish brown (in full sun), 1(-2)-celled gemmae. Sexual condition dioicous. Androecia intercalary, bracts in 4-6(10) pairs, similar to leaves but strongly inflated in the base, 3-8-androus. Gynoecia terminal, bracts in one pair, slightly larger than sterile leaves. Perianth oblong to obovate, dorsiventrally compressed, bend towards the ventral side at upper part, truncate, mouth denticulate to ciliate.

Species ca. 6 (3 in the flora): East Asia (Table 2).

\section{Key to the species of Scapania sect. Stephania in the Russian Far East and adjacent area}

1. Leaves with strongly, coarsely papillose cuticle; usually on decaying wood ............................................................. 1. S. birosakiensis.

1. Leaves with cuticle smooth to verrucose; usually on shaded wet rocks or rocks covered with thin soil .................................................. 2 .

2. Dorsal and ventral lobes rounded-obovate; ventral lobe 0.7-1.0

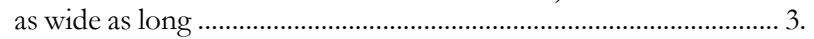
2. Dorsal and ventral lobes ligulate-obovate; ventral lobe 0.4-0.7

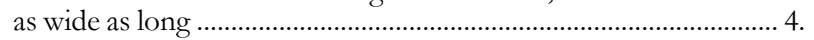
3. Dorsal lobe $0.7-0.8$ of ventral size; keel $0.5-0.6$ of ventral lobe length; gemmae green to yellowish brown in full sun ... 2. S. parvidens. 3. Dorsal lobe $0.5-0.7$ of ventral size; keel $0.4-0.5$ of ventral lobe length; gemmae green ................................................... 3. S. parvitexta. 4. Dorsal and ventral lobe with acute apex, usually flat; plants green to reddish brown ....................................................... S. integerrima, [mistakenly recorded for the Russian Far East by Bakalin (2010), but possible to find, Fig. 13]
4. Dorsal and ventral lobe with rounded apex, usually recurved; plants

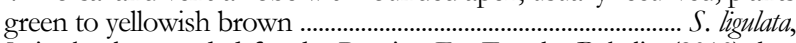
[mistakenly recorded for the Russian Far East by Bakalin (2010), but possible to find, Fig. 14]

1. Scapania hirosakiensis Steph., Nova Acta Acad. Caes. Leop.-Carol. German. Nat. Cur. 83: 120, 1905. (Fig. 15, 52: 20)

Description: Plants $10.0-15.0 \times 3.0-3.0 \mathrm{~mm}$, ascending to erect, yellowish green to green, sometimes pale reddish in herbarium. Stems sparsely branched, reddish brown near apex to reddish black below, cross section $0.25-0.35 \times 0.20-0.25 \mathrm{~mm}$, cortex cells thick-walled in 3-4 layers, 11.2-16.8 × 8.4-14.0 $\mu \mathrm{m}$ with reddish brown to reddish black walls; inner cells larger, thin-walled, $14.0-25.2 \times 14.0-25.2 \mu \mathrm{m}$ with colorless walls. Rhizoids sparse near apex and common below, fasciculate, spreading at right angle with stem, colorless. Leaves densely imbricate; keel $0.30-0.45$ of ventral lobe length, not winged, straight, ca. $70-90^{\circ}$ with stem axis; dorsal lobe subtransversely inserted, insertion line straight to slightly arched, not decurrent, obliquely ovate, $0.75-1.00 \times 0.50-0.75 \mathrm{~mm}, 0.4-0.5$ of ventral in size, ca. $40-50^{\circ}$ with stem axis, margin dentate, with teeth 1-3 cells long, 1-2 cells wide, apex obtuse to acute; ventral lobe transversely inserted, insertion line arched, slightly decurrent for $0.3-0.5$ of stem width, obliquely obovate, $1.2-1.5 \times 1.0-1.3$ $\mathrm{mm}(0.7-0.8: 1)$, ca. $50-70^{\circ}$ with stem axis, margin dentate, apex obtuse. Cells in the midleaf polygonal, 11.2-14.0 $\times$ 14.0-19.6 $\mu \mathrm{m}$ with triangular trigones; near margin with 

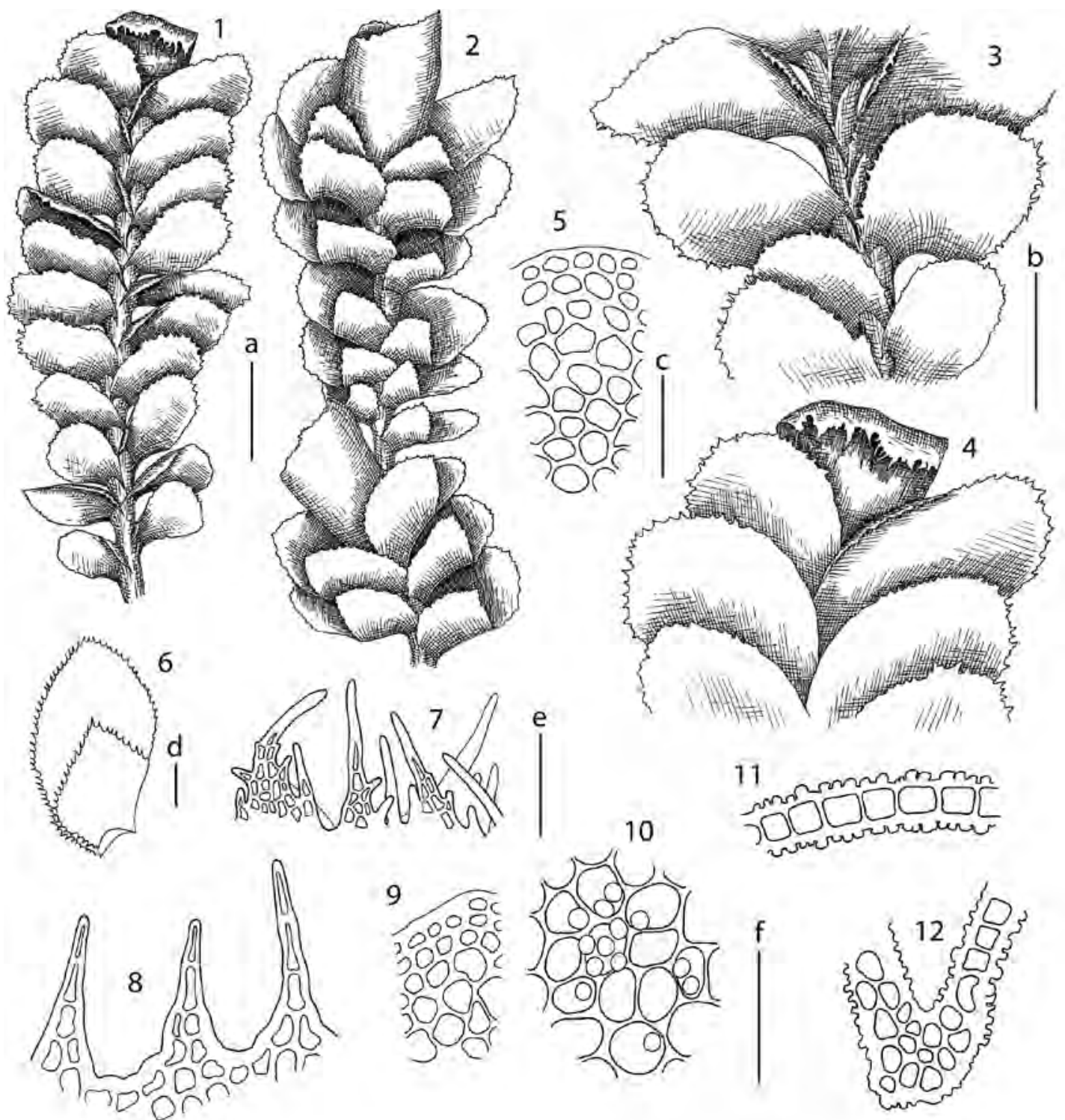

Figure 15 Scapania birosakiensis Steph. 1 - habit, ventral view; 2 - perianthous plant, dorsal view; 3 - part of shoot, ventral view; 4 - upper part of perianthous plant, ventral view; 5, 9- stem cross section, fragment; 6 - leaf; 7 - perianth mouth armature; 8 - leaf margin; 10 - midleaf cells; 11 - leaf cross section, fragment; 12 - keel cross section. Scales: a $-1 \mathrm{~mm}$, for 1,$2 ; \mathrm{b}-1 \mathrm{~mm}$, for 3,$4 ; \mathrm{c}-50 \mu \mathrm{m}$ for $5,8,9,11,12 ; \mathrm{d}-200 \mu \mathrm{m}$, for 6 ; $\mathrm{e}-100 \mu \mathrm{m}$ for 7 ; $\mathrm{f}-50 \mu \mathrm{m}$, for 10 .

2-3 cell rows equally thick-walled, rectangular, 11.2-14.0 $\times$ (12.0)14.0-19.6 $\mu \mathrm{m}$; at the base $28.0-42.0 \times 22.4-33.6 \mu \mathrm{m}$ with triangular trigones; cuticle papillose. Specialized asexual reproduction by gemmae in masses at apices of leaf-lobes, green, 1-celled, elliptical, 14.0-16.8 × 5.6-11.2 $\mu \mathrm{m}$, rarely occur. Sexual condition dioicous. Androecia intercalary, bracts in 6-10 pairs, similar to leaves, but strongly inflated in the base, 3-8-androus, ca. $100.0 \times 80.0 \mu \mathrm{m}$, antheridial stalk 1-seriate, ca. $100.0-120.0 \mu \mathrm{m}$ long. Gynoecia terminal, bracts in one pair, slightly larger than sterile leaves, dorsal lobe $1.50-1.75 \times 1.00$ $1.50 \mathrm{~mm}$; ventral lobe $2.0-2.5 \times 1.0-1.5 \mathrm{~mm}$. Perianth oblong to obovate, dorsiventrally compressed, truncate, ca. $2.5-3.5 \times$ 1.5-1.8 mm, mouth lobulate to ciliate, lobulae 3-6 cells long, $2-4$ cells wide.

Habitat: Decaying wood in coniferous forests in southern flank of treated area, 15-200 m alt.

Distribution: Sakhalin Province (Kurils Islands).

Comment: The species occupies intermediate position between sect. Aequilobae and sect. Stephanii. It resembles sect. Aequilobae in the character of coarsely papillose cuticle, but differs from the latter in slightly decurrent ventral lobe. Contrarily it resembles sect. Stephanii in weakly decurrent of ventral lobe, greenish $1(-2)$ celled gemmae and 3-4 layers of thick-walled cells along margin in stem cross section, but differs in coarsely papillose leaf cuticle. Provisionally we suggest position of S. hirosakiensis in sect. Stephanii more natural.

Specimens examined: SAKHALIN PROVINCE, Iturup Island, VB K-26-29-07, K-26-30-07, K-26-31-07, K-26-35-07, K-2717-07, K-27-26-07, K-28-7-07 (VBGI), VB K-32-7-07 (VBGI), Kunashir Island, VB K-38-7a-06, K-37-8-06, K-37-10a-06, K-3724-06, K-37-25b-06 (VBGI), VB K-42-4a-06 (VBGI), VB K-632-06 (VBGI), VB K-36-11a-06, K-36-14a-06 (VBGI), VB K-47-306, K-47-11a-06 (VBGI), VB K-50-1-06 (VBGI), VB K-52-20-06, K-53-2-06 (VBGI), Shikotan Island, VB K-37-11-07, K-37-12-07, K-37-13-07, K-37-20-07 (VBGI), VB K-40-22-07 (VBGI), VB K-49-48-07 (VBGI), VB K-57-13-07 (VBGI).

2. Scapania parvidens Steph., Hedwigia 44: 15, 1904. (Fig. 16, 52: 12)

Scapania okamurana Steph. ex Amak. \& S. Hatt., J. Hattori Bot. Lab. 12: 106. f. 13, 1954 syn. nov. 
Description: Plants ca. $6.0-10.0 \times 1.2-2.0 \mathrm{~mm}$, ascending to erect, in dense patches, pale green to reddish green in full sun. Stems $0.27-0.30 \times 0.22-0.25 \mathrm{~mm}$ in cross section, sparsely branched, surface brownish black, cortex cells thick-walled in 2-3 layers, $8.4-14.0 \times 5.6-11.2 \mathrm{~mm}$, inner cells larger, thin-walled, 14.0-28.0 × 8.4-14.0 mm with colorless walls. Rhizoids sparse to common, isolate, spreading at right angle with stem, colorless. Leaves transversely inserted, imbricate; keel 0.5-0.6 of ventral lobe length, straight, usually lamellate-winged, with wing $1-4(-10)$ cells wide, ca. $70-90^{\circ}$ with stem axis at the middle part; dorsal lobe transversely inserted, rectangular to rounded, obovate, dentate, $0.75-1.00 \times 0.6-0.75 \mathrm{~mm}, \mathrm{ca} .40-50^{\circ}$ with stem axis in the middle part of stem, $0.7-0.8$ of ventral in size, apex rounded to obtuse and subacute; ventral lobe transversely inserted, insertion line arched, slightly decurrent, rounded to obovate, apex rounded to obtuse and subacute, 1.00-1.25 ×
$0.75-1.00 \mathrm{~mm}(0.7-0.8: 1$ width of the length) margin dentate, teeth 1-2 cells long, 1-2 cells wide at base. Cells in the midleaf polygonal, $(20.0-) 24.0-36.4 \times 12.0-19.6 \mu \mathrm{m}$ with medium to large trigones; near apex 8.4-14.0 × 8.4-14.0 $\mu \mathrm{m}$, along margin $2-3$ cell rows equally thick-walled; near the base up to $28.0-39.2 \times 14.0-22.4 \mu \mathrm{m}$; cuticle striolate. Specialized asexual reproduction by gemmae in masses at apices of leaf-lobes, green to sometimes yellowish brown in full sun, 14.0-16.8 × 5.6-11.2 $\mu \mathrm{m}, 1$-celled, rarely in hypothetically autopolyploid races to $42.0-56.0 \times 32.0-36.4$ $\mu \mathrm{m}$ and 2-celled (VBGI: K-39-17a-06). Sexual condition dioicous. Androecia intercalary, bracts in 3-4 pairs, similar to leaves, but inflated in the base, $1(-2)$-androus, $120.0 \times 90.0$ $\mu \mathrm{m}$, antheridial stalk 1-seriate. Gynoecia terminal, bracts in one pair, similar to leaves, but larger. Perianth oblong, 1.65 $\times 1.50 \mathrm{~mm}$, truncate, dorsiventrally compressed, the upper part bend towards the ventral side, mouth dentate, teeth
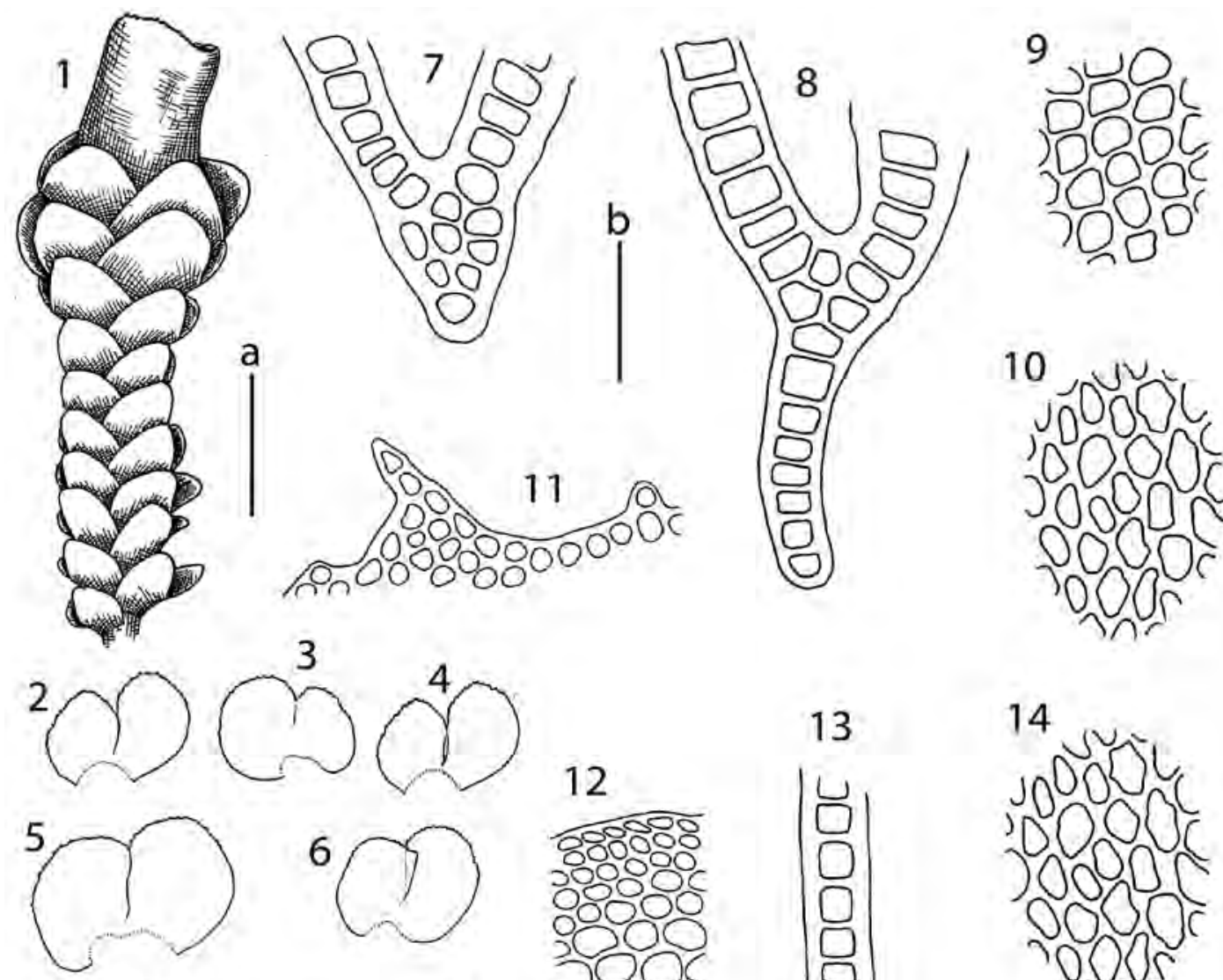

6
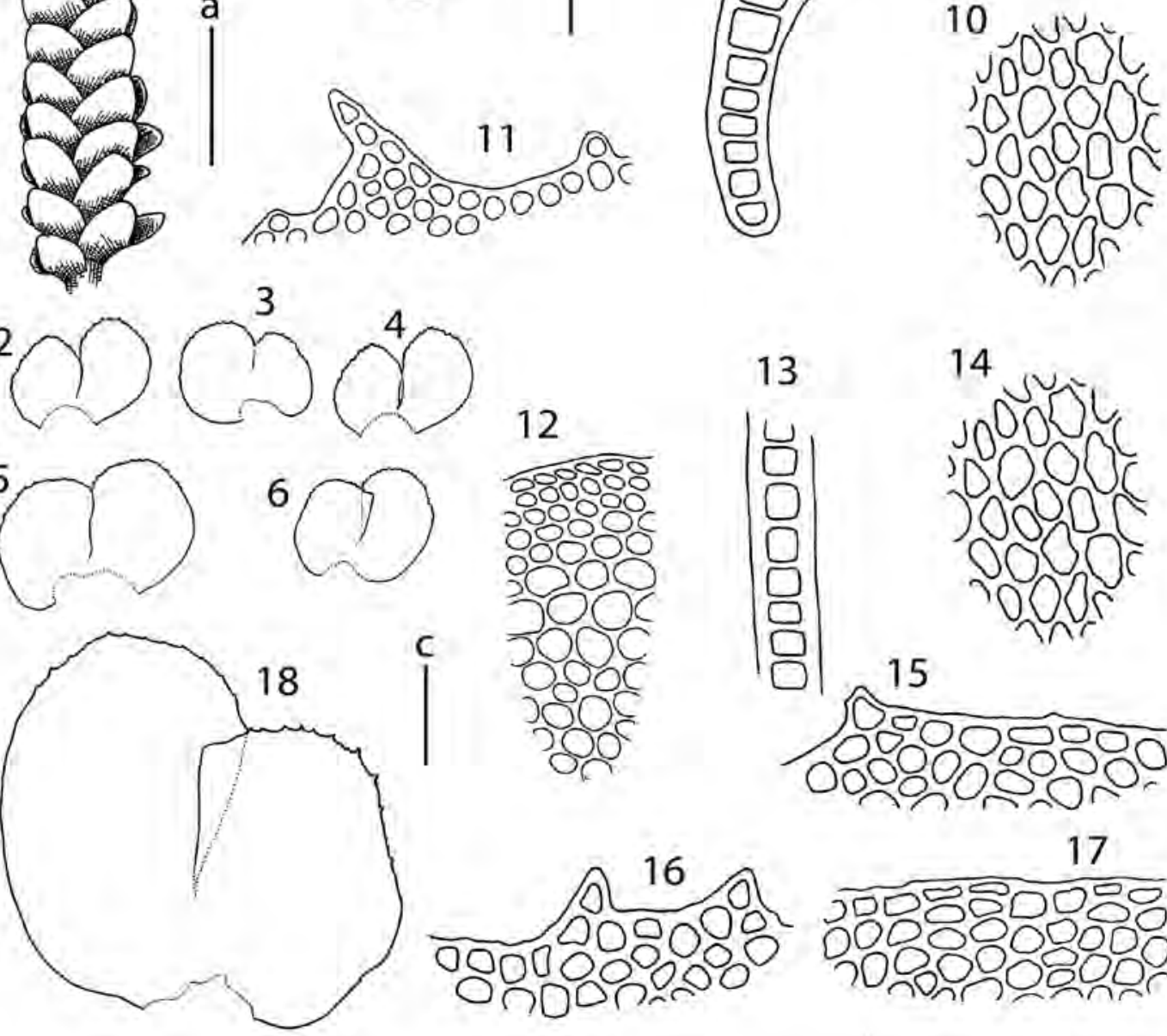

14
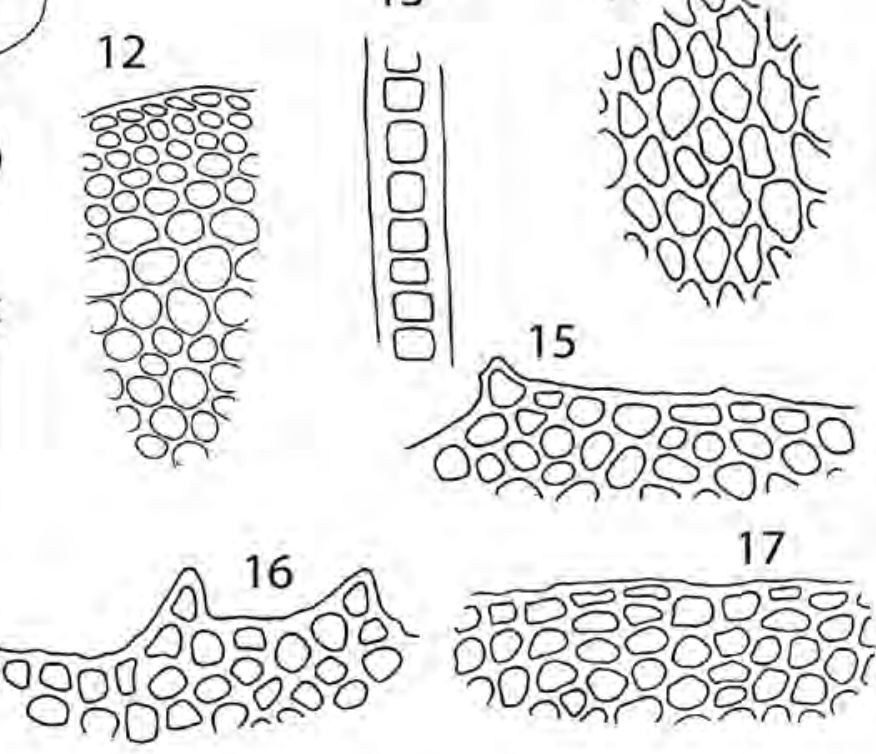

Figure 16 Scapania parvidens Steph. 1 - perianthous plant, dorsal view; 2-6, 18 - leaves; 7, 8 - keel cross section; 9, 10, 14 - midleaf cells; 11 - perianth mouth armature; 12 - stem cross section, fragment; 13 - leaf cross section, fragment; 15-17 - leaf margin. Scales: $\mathrm{a}-500 \mu \mathrm{m}$, for $1-6 ; \mathrm{b}-50 \mu \mathrm{m}$, for $7-17$; c $-200 \mu \mathrm{m}$, for 18 . 
5-6 cells long, 2-3 cells wide.

Habitat: wet fine-grained soil in cliff crevices, stones along small streams in coniferous forests; 18-1600 m alt.

Distribution: Sakhalin Province (Kurils Islands).

Comment: This species was described from Japan (Stephani 1904). Later, S. parvidens as well as S. okamurana and S. glaucoviridis were treated as synonyms of $S$. parvitexta by Potemkin (2002). However, judging from our study of the Scapania species in the Russian Far East, S. parvidens could be separated from $S$. parvitexta by: 1$)$ dorsal lobe $0.7-0.8$ of ventral in size, versus dorsal lobe $0.5-0.7$ of ventral in size, 2) keel 0.5-0.6 of ventral lobe length, versus keel $0.4-0.5$ of ventral lobe length and 3) gemmae green to yellowish brown in full sun, versus gemmae strictly green.

The additional note on $S$. okamurana is required too. The species was described on the basis of conspicuous keel wing, dentate margin of ventral lobe and yellowish brown 1-celled gemmae (Amakawa \& Hattori 1954). During our study of the specimens from Kurils Islands, we found these characters to be overlapping with the variation of $S$. parvidens. The similar variation of keel wing width we also found in $S$. parvitexta ( $0-5$ cells in the specimens from Korean Peninsula and Primorsky Territory). We consider the character of keel wing width as unstable in sect. Stephania. In accordance of this observation, we treat $S$. okamurana as synonymous of $S$. parvidens.

Specimens examined: SAKHALIN PROVINCE, Iturup Island VB K-22-8-07 (VBGI), VB K-58-24b-05, K-58-27-05 (VBGI), VB K-67-7-05 (VBGI), VB K-71-7-05 (VBGI), VB K-15-12-07 (VBGI), VB K-18-11-07, K-18-15-07, K-19-16-07, K-19-21-07 (VBGI), Kuna- shir Island, VB K-39-1a-06, K-39-17a-06, K-39-3a-06 (VBGI), VB K-58-6b-06 (VBGI), VB K-37-27-06, K-37-29a-06, K-37-31a-06 (VBGI), VB K-52-1-06, K-53-6c-06 (VBGI), Shikotan Island, VB K-38-5-07, K-38-25-07, K-38-31-07, K-38-34-07, K-34-44-07 (VBGI), VB K-42-9-07, K-42-36-07, K-42-52-07, K-43-6-07 (VBGI), VB K-45-19-07 (VBGI), VB K-47-3-07 (VBGI), VB K-60-8-07 (VBGI), VB K-66-2-07 (VBGI), VB K-65-19-07 (VBGI).

3. Scapania parvitexta Steph., Bull. Herb. Boissier 5: 107, 1897. (Fig. 17, 52: 10)

Description: Plants ca. $10.0-15.0 \times 2.0-2.5 \mathrm{~mm}$, ascending to erect, in dense patches, pale green, sometimes tinged with purple. Stems $0.24-0.34 \times 0.22-0.27 \mathrm{~mm}$ in cross section, surface green to brown, cortex cells thick-walled in 2-3 layers, 8.4-10.2 × 5.6-8.4 mm, inner cells larger, thin, 14.0-22.4 $\times 14.0-22.4 \mathrm{~mm}$ with colorless walls. Rhizoids sparse to common, fasciculate, spreading at right angle with stem, colorless. Leaves transversely inserted, imbricate; keel 0.4-0.5 of ventral lobe length, straight to slightly arched, weakly lamellatewinged with wing $1-5$ cells wide, ca. $80-90^{\circ}$ with stem axis at the middle part; dorsal lobe transversely inserted, not decurrent, rectangular to obovate, $0.65-0.80 \times 0.60-0.75 \mathrm{~mm}$, ca. $40-50^{\circ}$ with stem axis in the middle part of stem, $0.6-0.7$ of ventral lobe in size, margin dentate; ventral lobe ovate to rounded and obovate, slightly decurrent, $1.00-1.15 \times 0.75-0.85 \mathrm{~mm}, 0.7: 1$

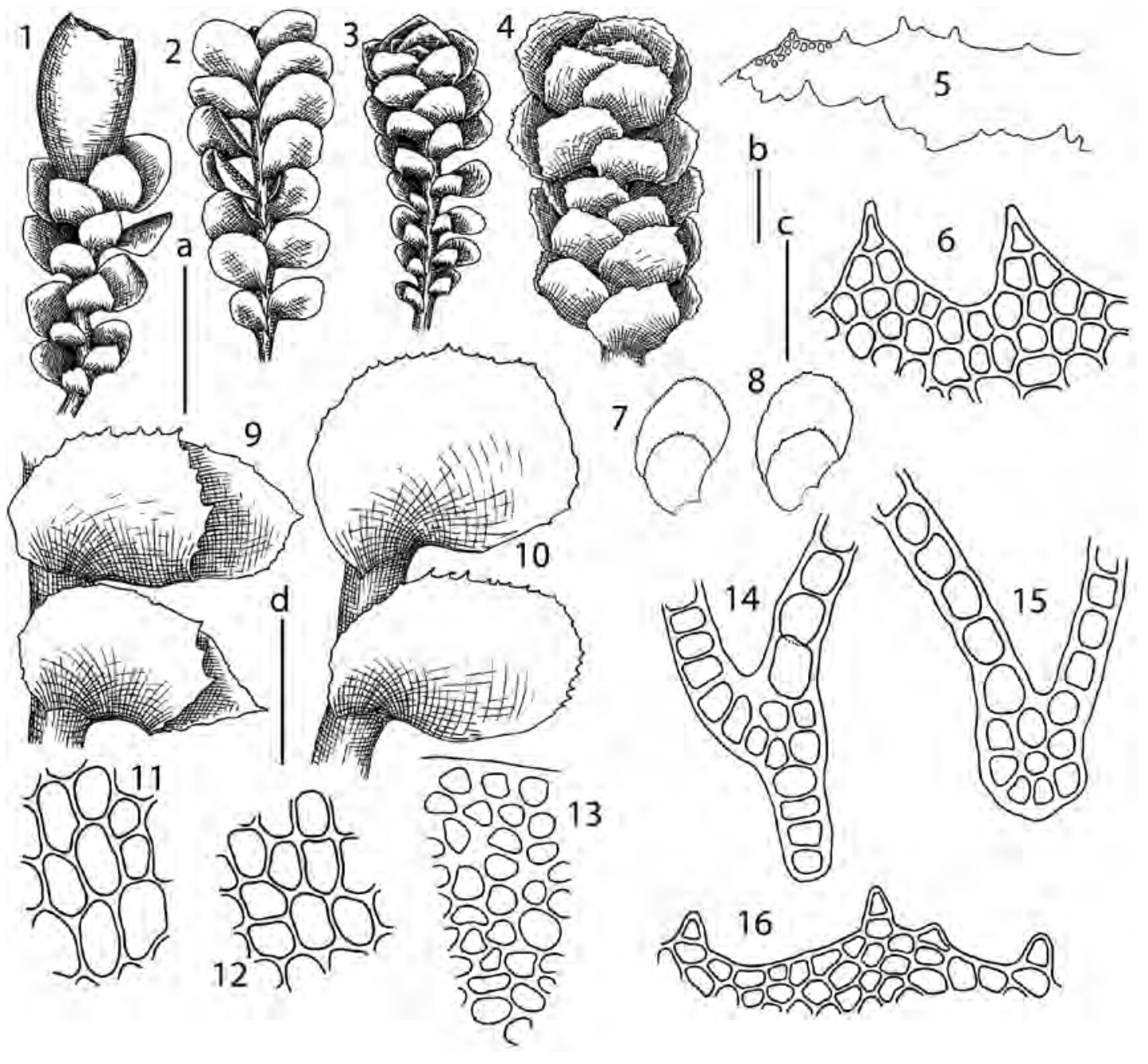

Figure 17 Scapania parvitexta Steph. 1 - perianthous plant, dorsal view; 2 - habit, ventral view; 3, 4 - habit, dorsal view; 5 - perianth mouth armature, fragment; 6 - leaf apex; 7, 8 - leaves; 9 - dorsal lobe insertion; 10 - ventral lobe insertion; 11 - leaf base cells; 12 - midleaf cells, 13 - stem cross section, fragment; 14, 15 - keel cross section; 16 - leaf margin. Scales: $\mathrm{a}-1 \mathrm{~mm}$, for $1-4,7,8 ; \mathrm{b}-100 \mu \mathrm{m}$, for $5 ; \mathrm{c}-50 \mu \mathrm{m}$, for $6,11-16 ; \mathrm{d}-500 \mu \mathrm{m}$, for 9,10 . 
width of the length, margin dentate, teeth 1-3 cells long, 1-3 cells wide, insertion line arched. Cells in the midleaf polygonal, $(16.0-) 20.0-33.6 \times 11.2-19.6 \mu \mathrm{m}$, near apex 11.2-18.0 $\times$ $11.2-17.0 \mu \mathrm{m}$, along margin $2-3$ cell rows equally thick-walled; near base $(16.0-) 24.0-42.0 \times 12.0-19.6 \mu \mathrm{m}$ with distinct to large trigones; cuticle weakly striolate to verrucose. Specialized asexual reproduction by gemmae in masses at apices of leaf-lobes, green, 14.0-19.6 × 10.2-14.0 $\mu \mathrm{m}, 1(-2)$-celled, elliptical. Sexual condition dioicous. Androecia intercalary, bracts in 3-4 pairs, similar to leaves, but inflated in the base, $1(-2)$-androus, body ca. $150.0 \times 120.0 \mu \mathrm{m}$, antheridial stalk 1-seriate. Gynoecia terminal, bracts in one pair, similar to leaves, but larger. Perianth oblong, $2.0-2.5 \times 1.5 \mathrm{~mm}$, truncate, dorsiventrally compressed, upper part bend toward the ventral side, mouth dentate, teeth 3-6 cells long, 3-5 cells wide.

Habitat: Shady rocks in canyon-like stream valleys in mountain coniferous with admixture broad-leaved trees forests; $413 \mathrm{~m}$ alt.

Distribution: Primorsky Territory.

Specimens examined: PRIMORSKY TERRITORY, Shkotovsky District, VB P-72-4-05, P-72-5a-05, P-72-25-05 (VBGI).

SCAPANLA SECT. KAALAASLA H. Buch, Soc. Sci. Fennica, Comm. Biol. 3(1): 47. 1928.

Description: Plants ca. $10.0-20.0 \times 1.0-2.0 \mathrm{~mm}$, prostrate to ascending, green to brownish green. Stems sparsely branched, green to brown, cortex cells thick-walled in one layer in cross section. Rhizoids numerous, colorless. Leaves contiguous; keel $0.3-0.5$ of ventral lobe length, straight to slightly arched; dorsal lobe transversely inserted, not decurrent, obliquely rectangular to ovate, $0.4-0.7$ of ventral in size, margin entire, apex acute; ventral lobe subtransversely to transversely inserted, not decurrent, narrowly ovate. Cells in the midleaf polygonal, with concave trigones; along margin thin-walled; cuticle weakly striolate. Oil-bodies 1-5(-6) per cell, irregularly spherical to shortly elliptic, filling cell lumen, brownish, mostly longpersistent. Specialized asexual reproduction by gemmae in masses at apices of leaf-lobes, ovate to elliptical, (1-)2-celled, brown. Sexual condition dioicous. Androecia intercalary, bracts in 3-4 pairs, similar to leaves, but inflated in the base, 1-androus. Gynoecia terminal, bracts in one pair, similar to leaves but larger. Perianth obovate to broadly elliptical, plicate, mouth ciliate-dentate to lobulate.

Species 3 ( 2 in the flora): North America, Eurasia.

\section{Key to the species of Scapania sect. Kaalaasia} in the Russian Far East

1. Oil-bodies usually one per cells, larger; keel $0.30-0.43$ of ventral lobe length; gemmae smaller, $20.0-25.0 \times 12.5-15.0 \mu \mathrm{m}$ 1. S. gymnostomophila.

1. Oil-bodies usually $2-4$ per cells, smaller; keel $0.60-0.65$ of ventral lobe length; gemmae larger $24.0-32.0 \times 16.0-21.0 \mu \mathrm{m}$ [strictly

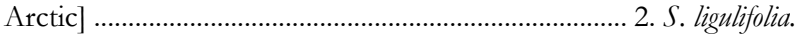

1. Scapania gymnostomophila Kaal., Bot. Notiser,

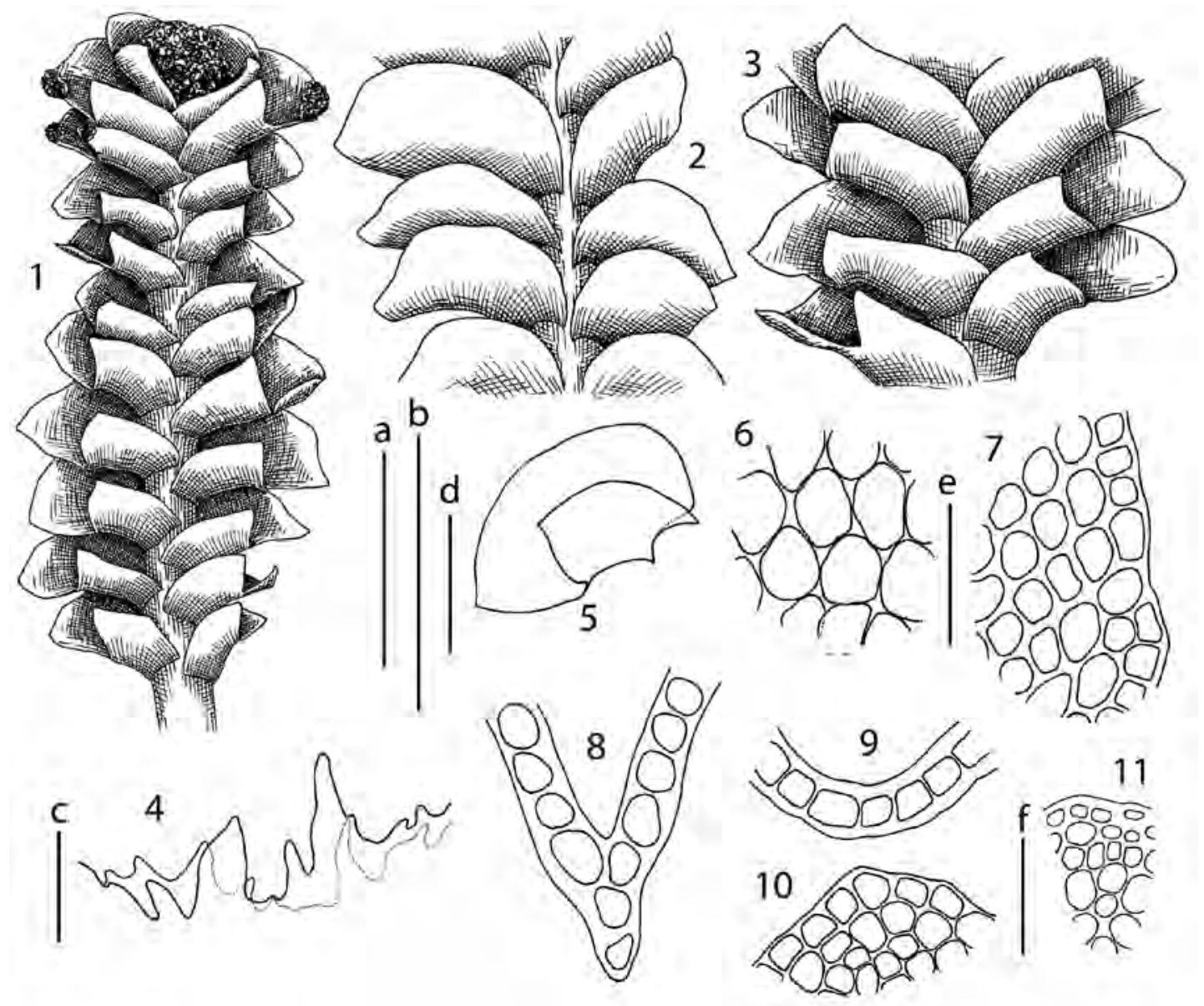

Figure 18 Scapania gymnostomopbila Kaal. 1 - habit, dorsal view; 2 - part of shoot, ventral view; 3 - part of shoot, dorsal view; 4 - perianth mouth armature; 5 - leaf; 6 - midleaf cells; 7 - leaf margin; 8,9- keel cross section; 10 - leaf apex; 11 - stem cross section, fragment. Scales: $\mathrm{a}-1 \mathrm{~mm}$, for $1 ; \mathrm{b}-1 \mathrm{~mm}$, for 2,$3 ; \mathrm{c}-100 \mu \mathrm{m}$ for 4 ; $\mathrm{d}-500 \mu \mathrm{m}$, for 5 ; $\mathrm{e}-50 \mu \mathrm{m}$, for $6-10$; $\mathrm{f}-50 \mu \mathrm{m}$, for 11 . 
21, 1896. (Fig. 18, 52: 21)

Description: Plants ca. 10.0-20.0 × 1.4-2.0 mm, prostrate to ascending, green to brownish green. Stems sparsely branched, dorsal surface green to brown, ventral surface brown, cross section $0.30-0.35 \times 0.20-0.25 \mathrm{~mm}$, cortex cells thick-walled in 1 layer, $5.0-7.5 \times 10.0-12.5 \mu \mathrm{m}$, inner cells larger, thin-walled, $12.5-17.5 \times 17.5-25 \mu \mathrm{m}$, with colorless walls. Rhizoids numerous, colorless. Leaves contiguous; keel $0.30-0.43$ of ventral lobe length, straight to slightly arched, weakly lamellate-winged, ca. $60-90^{\circ}$ with stem axis at the middle part; dorsal lobe transversely inserted, not decurrent, obliquely rectangular to ovate, $0.40-0.60 \times 0.25-0.30 \mathrm{~mm}, 0.4-0.7$ of ventral in size, ca. $50-60^{\circ}$ with stem axis, margin entire, apex acute; ventral lobe subtransversely to transversely inserted, not decurrent, narrowly ovate, somewhat falcate, concave, $0.6-1.0 \times 0.4$ $0.6 \mathrm{~mm},(0.4-0.6: 1$ as long as wide), margin usually entire, sometimes with small teeth, apex obtuse to apiculate. Cells in the midleaf polygonal, $20.0-29.0 \times 15.0-25.0 \mu \mathrm{m}$ with concave trigones; near apex 7.5-15.5 $\times 10.0-15.0 \mu \mathrm{m}$, along margin thin-walled; at the base $25.0-50.0 \times 12.5-17.5 \mu \mathrm{m}$ with distinct trigones; cuticle weakly striolate. Oil-bodies $1(-2)$ per cell, irregularly spherical to shortly elliptic, filling cell lumen, 14.0-19.6 × 9.0-16.0 $\mu \mathrm{m}$, granulate, brownish. Specialized asexual reproduction by gemmae in masses at apices of leaf-lobes, ovate to elliptical, 20.0-25.0 × 12.5$15.0 \mu \mathrm{m},(1-) 2$-celled, brown. Sexual condition dioicous. Androecia intercalary, bracts in 3-4 pairs, similar to leaves, but inflated at the base, 1 -androus, body ca. $150.0 \times 125.0$ $\mu \mathrm{m}$, antheridial stalk 1-seriate. Gynoecia terminal, bracts in 1 pair, similar to leaves but larger, dorsal lobe $0.70-0.90 \times$ $0.30-0.35 \mathrm{~mm}$; ventral lobe $1.2-1.5 \times 0.5-0.6 \mathrm{~mm}$. Perianth obovate to broadly elliptical, $2.0-2.4 \times 0.7-0.8 \mathrm{~mm}$, plicate, mouth ciliate-dentate to lobulate with teeth usually $1-3(-4)$ cells long, 1-2(-3) cells wide. Elaters 2-spiral, ca. 100.0$125.0 \times 5.0-7.5 \mu \mathrm{m}$. Spores ca. $12.5-15.0 \mu \mathrm{m}$ in diameter, brown.

Habitat: Mineral and peaty soil in the crevices of gravelly barrens field in tundra belt, cliff crevices in subalpine belt; confined to the basic habitats; 600-1150 m alt.

Distribution: Amurskaya Province, Sakhalin Province, Kamchatka Territory, Magadan Province, Chukotka Province.

Specimens examined: AMURSKAYA PROVINCE, Udokan Range, VB Am-22-11-00 (KPABG, VBGI); SAKAHALIN PROVINCE, Vostochno-Sakhalinskiye Mts., VB S-32-14-06, S-32-28b-06 (VBGI), M.S. Ignatov 20.VIII.2006 G21 (VBGI); KAMCHATKA TERRITORY, Ushkovsky volcano, VB K-488-03 (VBGI); MAGADAN PROVINCE, Khasynsky District, VB Mag-9-19-10 (VBGI), Khasynsky District, VB Mag-7-41-10 (VBGI), Khasynsky District, VB Mag-11-16-10, Mag-12-7-10 (VBGI).

2. Scapania ligulifolia R.M. Schust., Hepat. Anthocerotae N. Amer. 3: 306, 1974. (Fig. 19, 52: 18)

Description: Plants $5.0-15.0 \times 1.0-1.5 \mathrm{~mm}$, prostrate, fuscous green, brownish green to green. Stems sparsely branched, pale brownish green near apex, fuscous brown below, cross section $0.20-0.25 \times 0.32-0.37 \mathrm{~mm}$, cortex cells thick-walled in 1(-2) layers, $11.3-16.2 \times 8.1-11.3 \mu \mathrm{m}$ with

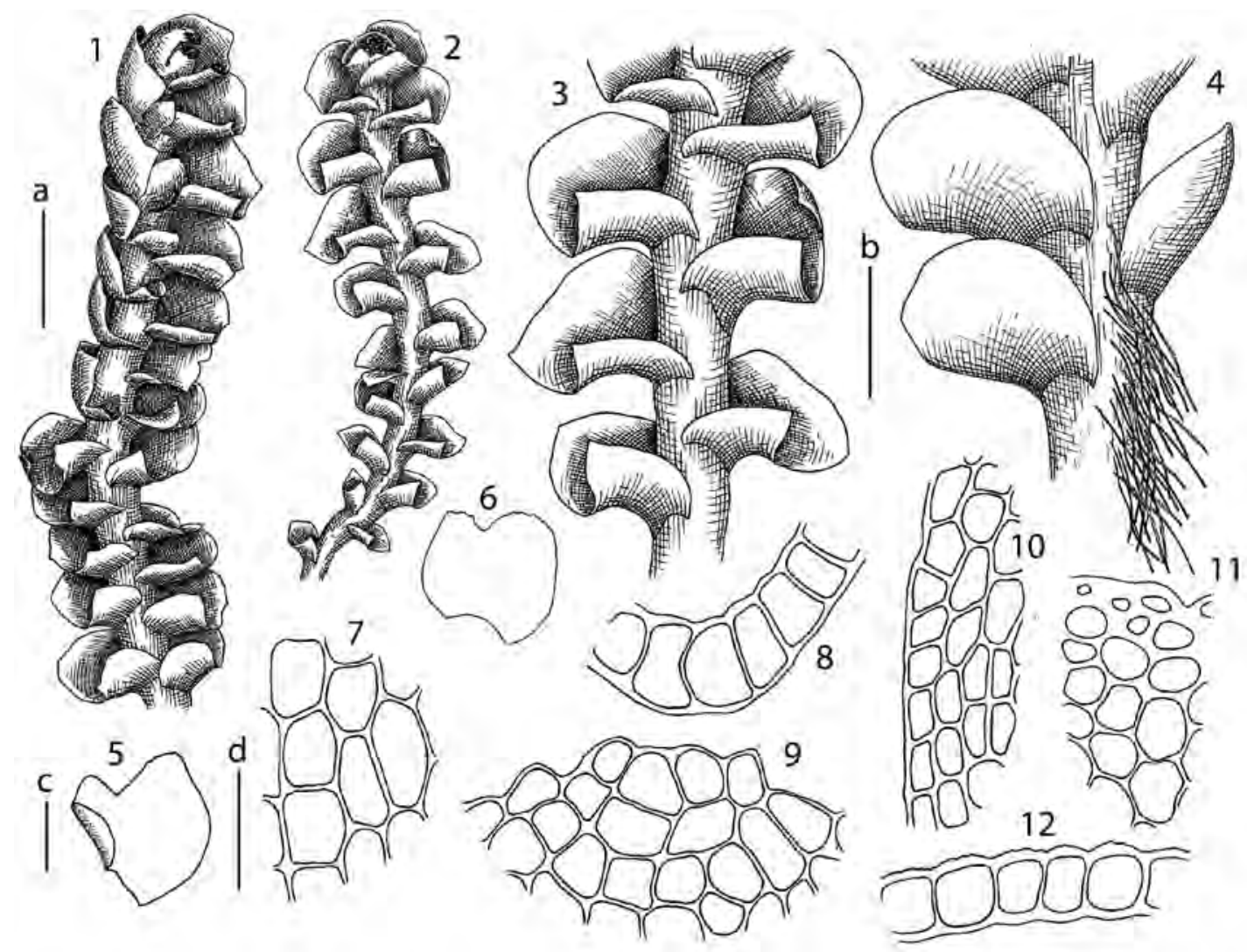

Figure 19 Scapania ligulifolia R.M. Schust. 1, 2 - habit, dorsal view; 3 - part of shoot, dorsal view; 4 - part of shoot, ventral view; 5, 6- leaves; 7 - midleaf cells, 8 - keel cross section; 9 - leaf apex; 10 - leaf margin; 11 - stem cross section, fragment; 12 - leaf cross section, fragment. Scales: $\mathrm{a}-1 \mathrm{~mm}$, for 1,$2 ; \mathrm{b}-500 \mu \mathrm{m}$, for 3, 4; c $-500 \mu \mathrm{m}$, for 5,$6 ; \mathrm{d}-50 \mu \mathrm{m}$, for $7-12$. 
fuscous brown walls; inner cells larger, thin-walled, 11.3$24.3 \times 11.3-24.3 \mu \mathrm{m}$ with colorless walls. Rhizoids sparse to numerous, in dense fascicles, spreading at right angle with stem, colorless. Leaves contiguous; keel $0.60-0.65$ of ventral lobe length, straight to slightly arched, ca. $70-80^{\circ}$ with stem axis at the middle part and up to $90-100^{\circ}$ at the end; dorsal lobe transversely inserted, not decurrent, obliquely oblong to obovate, $0.50-0.62 \times 0.25-0.37 \mathrm{~mm}, 0.6-0.7$ of ventral in size, ca. $45-60^{\circ}$ with stem axis, margin entire, apex obtuse to acute; ventral lobe transversely inserted, insertion line slightly arched, not decurrent, obliquely oblong to obovate, concave, slightly falcate, $0.70-0.80 \times 0.45-0.55 \mathrm{~mm}$, (0.65-0.75 : 1), ca. $70-90^{\circ}$ with stem axis, margin entire, apex obtuse to acute. Cells in the midleaf obliquely oblong, 24.3-32.4 × 16.2-28.3 $\mu \mathrm{m}$ with concave trigones; near apex rectangular 13.0-25.5 × 13.0-24.5 $\mu \mathrm{m}$, thick-walled; at the base $32.4-40.5 \times 13.0-16.2 \mu \mathrm{m}$, thick-walled; cuticle weakly striolate. Oil bodies $2-4(-5)$ per cells, granulate, spherical to elliptical, $6.5-8.1 \mu \mathrm{m}$ in diameter, fuscous brown. Specialized asexual reproduction by gemmae in masses at apices of leaves, elliptical to ovate, 24.3-32.4 $\times$
16.2-21.1 $\mu \mathrm{m}, 2$-celled, weakly constricted in the middle, deep brown. Sexual condition dioicous. [Perianth ovoidellipsoidal, inflated, hardly dorsiventrally compressed, often deeply plicate almost to base (Schuster, 1974).].

Habitat: Over soil and peat in bogs developed on calcareous substrata, confined to Arctic tundras; elevation unknown. (Schljakov 1981).

Distribution: Chukotka Province.

[Specimens examined: NORWAY, Svalbard Archipelago, N.A. Konstantinova K-41-1a-10, K-41-2a-10, K-49-10 (KPABG, VBGI).]

SCAPANLA SECT. SCAPANIELLA H. Buch, Soc. Sci. Fennica, Comm. Biol. 3(1): 33, 1928.

Description: Plants ca. 2.0-5.0 × 1.0-1.5 mm, ascending to erect, green. Stems sparsely branched, green to greenish brown, in cross section cortex cells slightly thickwalled in one layer. Rhizoids sparse to common, isolate to fasciculate, spreading at right angle with stem. Leaves contiguous, loosely complicate; keel $0.6-0.7$ of ventral lobe length, straight to slightly arched; dorsal lobe insertion line

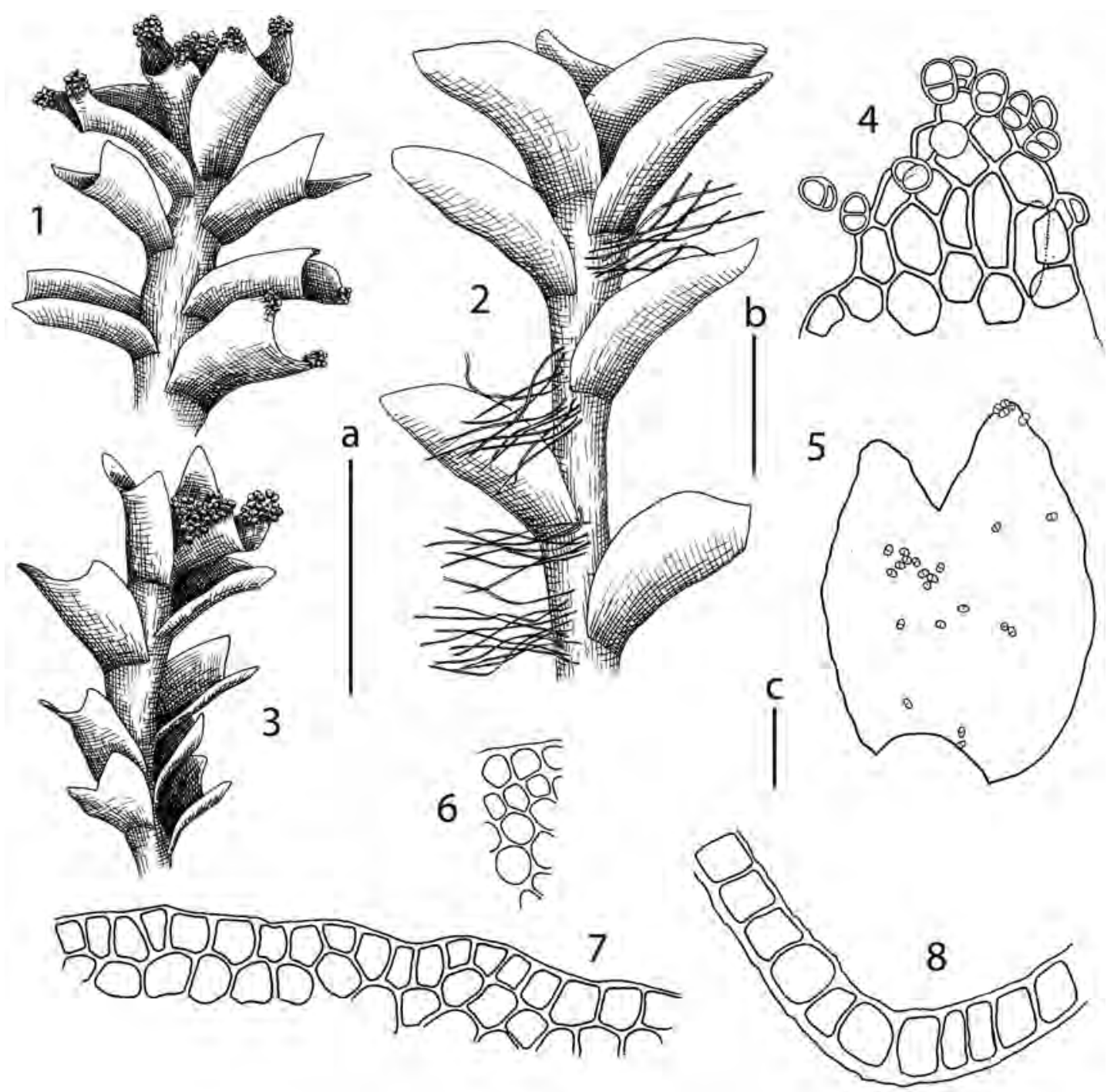

Figure 20 Scapania glancocephala (Tayl.) Aust. 1, 3 - gemmiparous plants, dorsal view; 2 - habit, ventral view; 4 gemmiparous leaf apex; 5 - leaf with showed gemmae; 6 - stem cross section, fragment; 7 - perianth mouth armature; 8 - keel cross section. Scales: $\mathrm{a}-1 \mathrm{~mm}$, for $1-3 ; \mathrm{b}-50 \mu \mathrm{m}$, for $4,6-8 ; \mathrm{c}-100 \mu \mathrm{m}$, for 5 . 
slightly arched, not decurrent, obliquely obovate, 0.6-0.7 of ventral in size, margin entire, apex acute; ventral lobe insertion line arched, not or barely decurrent, obliquely obovate, concave, margin entire, apex acute. Cells in the midleaf oblong-rectangular; near apex along margin 1-2 cells rows equally thick-walled or thin-walled; cuticle striolate. Specialized asexual reproduction by gemmae in masses at apices of leaf-lobes, (1-)2-celled, reddish brown to brown. Sexual condition dioicous.

Species ca. 5 ( 2 in the flora): North America, Eurasia.
Key to species of Scapania sect. Scapaniella in the Russian Far East.

1. Gemmae reddish brown, smaller, 14.0-19.6 × 11.2-14.0 mm; leaves not crispate; marginal cells of ventral lobe in $1-2$ cell rows thick-walled [on decaying wood in forested area]

1. S. glaucocephala.

1. Gemmae brown, larger $25.0-30.0 \times 12.5-17.5 \mathrm{~mm}$; leaves slightly crispate; marginal cells of ventral lobe thin-walled; on peaty soil in boggy area [on soil, strictly Arctic] ............. 2. S. zemliae.

1. Scapania glaucocephala (Tayl.) Aust., Bull. Torrey Bot. Club 6: 85, 1876. (Fig. 20, 52: 22)

Description: Plants small, ca. $2.0-5.0 \times 1.0-1.5 \mathrm{~mm}$, ascending to erect, green. Stems sparsely branched, dorsal
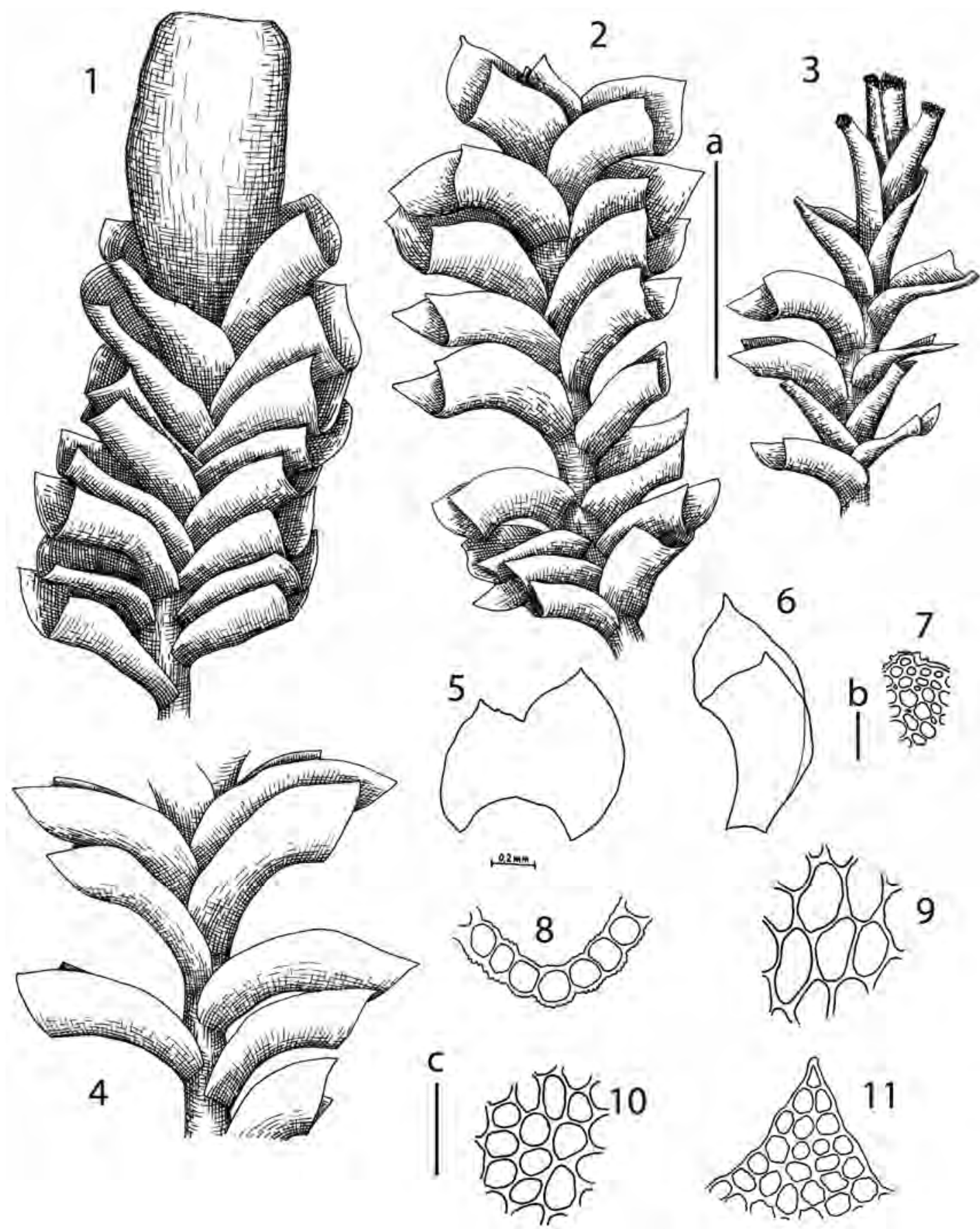

Figure 21 Scapania apiculata Spruce 1 - perianthous plant habit, dorsal view; 2 - habit, doral view; 3 - gemmaparous plant habit; 4 - habit, ventral view; 5, 6-leaves; 7 - stem cross section, fragment; 8 - keel cross section; 9 - ventral lobe basal cells; 10 - ventral lobe middle cells; 11 - leaf apex. Scales: a $-1 \mathrm{~mm}$ for $1-4 ; \mathrm{b}-200 \mu \mathrm{m}$, for $5,6, \mathrm{c}-50 \mu \mathrm{m}$, for $7 ; \mathrm{d}-50 \mu \mathrm{m}$, for $8-11$. 
surface green, ventral surface green to greenish brown, cross section $0.22-0.30 \times 0.20-0.22 \mathrm{~mm}$, cortex cells in cross section slightly thick-walled in one layer, 14.0-22.4 $\times$ $14.0-22.4 \mathrm{~mm}$ with greenish brown walls; inner cells slightly larger, thin-walled, 22.4-28.0 × 22.4-28.0 mm, polygonal with colorless walls. Rhizoids sparse to common, isolate, spreading at right angle with stem, colorless. Leaves contiguous, loosely complicate; keel $0.6-0.7$ of ventral lobe length, straight to slightly arched, ca. $40-50^{\circ}$ with stem axis at the middle part and up to $100^{\circ}$ at the end; dorsal lobe insertion line slightly arched, not decurrent, obliquely obovate, $0.54-0.60 \times 0.30-0.36 \mathrm{~mm}, 0.6-0.7$ of ventral in size (in gemmiparous shoots dorsal lobe ca. 0.8-0.9 of ventral in size), ca. $40-60^{\circ}$ with stem axis, margin entire, apex acute; ventral lobe insertion line arched, not or barely decurrent, obliquely obovate, concave, $0.68-0.83 \times 0.33-0.40 \mathrm{~mm}$, (0.4-0.6 : 1), ca. $60^{\circ}-90^{\circ}$ with stem axis, margin entire, apex acute. Cells in the midleaf oblong-rectangular, 19.6$28.0 \times 14.0-28.0 \mathrm{~mm}$ with concave trigones; near apex $11.2-24.0 \times 14.0-22.4 \mathrm{~mm}$, along margin with $1-2$ cells rows equally thick-walled; near base 19.6-30.8 × 19.6-28 $\mathrm{mm}$ with concave trigones; cuticle striolate. Specialized asexual reproduction by gemmae in masses at apices of leaf-lobes of specialized attenuate shoot tips, 14.0-19.6 $\times$ 11.2-14.0 mm, (1-)2-celled, reddish brown, gemmiparous leaves smaller than sterile ones. Sexual condition dioicous. [Perianth strongly dorsiventrally flatted, mouth entire to sinuate-lobed (Schuster, 1974).].

Habitat: Shaded decaying wood in Populus-Chosenia flood-plane forests in subalpine belt; $450 \mathrm{~m}$ alt.

Distribution: Kamchatka Territory.

Specimens examined: KAMCHATKA TERRITORY, Central Kamchatka, Tigil' River Basin, VB K-131-8-04, K-131-22-04 (VBGI).

\section{Scapania zemliae S.W. Arnell, Svensk Bot. Tidskrift} 41: 215, 1947.

Plants $6.0-10.0 \times 1.0-2.0 \mathrm{~mm}$, prostrate to ascending, green to reddish brown. Stems sparsely branched, dorsal surface reddish brown, ventral surface deep reddish brown, cross section $0.35-0.45 \times 0.20-0.30 \mathrm{~mm}$, cortex cells thickwalled in one layer, $12.5-25 \times 10.0-12.5 \mathrm{~mm}$, with reddish brown walls; inner cells larger, thin-walled, 25.0-30.0 $\times$ 20.0-25.0 $\mathrm{mm}$ with colorless walls. Rhizoids sparse to common or numerous, fasciculate, spreading at right angle with stem, colorless to pale brown. Leaves contiguous; keel $0.7-0.8$ of ventral lobe length, straight to slightly arched, ca. $30-60^{\circ}$ with stem axis at the middle part and up to $80-110^{\circ}$ at the end; dorsal lobe transversely inserted, not decurrent, obliquely ovate to rectangular, $0.5-0.7 \times 0.3-0.5 \mathrm{~mm}, 0.5-$ 0.6 of ventral in size, ca. $30-50^{\circ}$ with stem axis, margin entire, slightly undulate, apex obtuse to acute; ventral lobe transversely inserted, insertion line arched, not decurrent, broadly ovate, $1.0-1.2 \times 0.7-0.8 \mathrm{~mm},(0.65-0.70: 1)$, ca. 70 $90^{\circ}$ with stem axis, margin entire, apex rounded to obtuse, slightly undulate. Cells in the midleaf oblong to rectangular, $25.0-30.0 \times 20.0-25.0 \mathrm{~mm}$ with triangular trigones; near apex 12.5-17.5 × 12.5-20.0 mm, cells along margin thinwalled (only near the base somewhat thick-walled), with triangular trigones; near base $25.0-37.5 \times 20.0-25.0 \mathrm{~mm}$ with concave trigones; cuticle smooth to weakly striolate.
Specialized asexual reproduction by gemmae in masses at apices of shoot, elliptical, 25.0-30.0 × 12.5-17.5 mm, 2-celled, brown. Sexual condition dioicous.

Habitat: Mineral and peaty soil in boggy habitats in tundra zone (Schljakov, 1981); elevation unknown.

Distribution: Chukotka Province.

[Specimens examined: EUROPEAN ACRTIC, Franz-Josef Land coll. unknown (KPABG).]

SCAPANLA SECT. APICULATAE H. Buch, Soc. Sci. Fennica, Comm. Biol. 3(1): 53, 1928.

Scapania sect. Brevicaules R.M. Schust., Hepat. Anth. North Amer. 3:371, 1974. syn. nov.

Description: Plants 10.0-30.0 × 1.0-2.0 mm, ascending to erect, yellowish green to brownish green. Stems sparsely branched, pale brownish near apex, brown below; cross section with cortex cells thick-walled in 1-2 layers. Rhizoids sparse to numerous, fasciculate, spreading at right angle with stem, colorless. Leaves contiguous to imbricate; keel 0.5 0.7 of ventral lobe length; dorsal lobe transversely inserted, usually not decurrent, broadly obliquely subrectangular to obovate, arching over stem and beyond stem, slightly convex, margin entire, apex obtuse to acute; ventral lobe transversely inserted, insertion line arched, commonly not decurrent or sometimes shortly decurrent, $0.4-0.7: 1$. Oil bodies 3-6 per cells, granulate, spherical to elliptical. Specialized asexual reproduction by gemmae in masses at apices of shoots or leaf-lobes, elliptical, 1-celled, reddish brown to deep brown. Sexual condition dioicous. Perianth oblong to obovate, dorsiventrally compressed, truncate, mouth entire to denticulate.

Species ca. 3 (3 in the flora): North America, Eurasia (Table 3).

\section{Key to species of Scapania sect. Apiculatae \\ in the Russian Far East.}

1. Leaves with marginal cells thin-walled . 2.

2. Gemmiparous shoots gradually narrowed to the apex; ventral lobe $0.45-0.60$ as wide as long; gemmae reddish brown, 11.2-14.0 $\mathrm{mm}$; on decaying wood in forests .................................. 1. S. apiculata. 2. Gemmiparous shoots dilated to the apex; ventral lobe $0.6-0.7$ as wide as long; gemmae deep brown, 15.0-17.5 mm; on soil or peat in tundra belt .............................................................. 2. S. brevicaulis. 1. Leaves with marginal 2-3 cell rows equally thick-walled ...

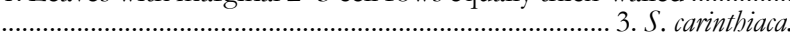

1. Scapania apiculata Spruce, Ann. and Mag. Nat. Hist. II(4): 106, 1849. (Fig. 21).

Description: Plants 3.0-3.5 × 1.0-2.0 mm (gemmiparous shoots smaller, $1.7-2.0 \times 0.5-1.2 \mathrm{~mm}$ ), ascending to erect, green to yellowish green or brownish green. Stems sparsely branched, dorsal surface greenish brown, ventral surface brown, cross section $0.15-0.17 \times 0.15-0.17 \mathrm{~mm}$, with cortex cells thick-walled in 1-2 layers, 11.2-14.0 $\times$ 8.4-11.2 mm with brown walls; inner cells larger, thinwalled, $16.8-28.0 \times 14.0-22.4 \mathrm{~mm}$ with colorless walls. Rhizoids sparse to common, colorless to pale brown. Leaves densely imbricate (contiguous in gemmiparous shoot); keel $0.50-0.65$ of ventral lobe length, straight to slightly arched, ca. $40-50^{\circ}$ with stem axis at the middle part and up to $100^{\circ}$ at the end; dorsal lobe transversely inserted, not decurrent, obliquely rectangular to obovate, $0.30-0.75$ 
$\times 0.15-0.22 \mathrm{~mm}, 0.6-0.8$ of ventral in size, ca. $30-50^{\circ}$ with stem axis, margin entire, apex acute; ventral lobe insertion line slightly arched, not decurrent, obliquely obovate, 0.45 $1.00 \times 0.22-0.30 \mathrm{~mm},(0.45-0.60: 1), \mathrm{ca} .40-70^{\circ}$ with stem axis, margin entire, apex acute to apiculate. Cells in the midleaf polygonal, 15.0-33.6 $\times 12.8-22.4 \mathrm{~mm}$ with convex trigones; near apex 9.0-14.0 × 8.0-19.6 mm, along margin thin-walled, with slightly convex trigones; at the base rectangular 33.6-47.6 × 19.6-22.4 mm with convex trigones; cuticle distinctly verrucose to striolate. Oil bodies 3-5 per cells, elliptical, $6.0-10.0 \times 4.0-6.0 \mathrm{~mm}$, finely granulate. Specialized asexual reproduction by gemmae in masses at apices of leaf-lobes, elliptical, 11.2-14.0 × 7.5-8.5 $\mathrm{mm}, 1$-celled, reddish brown, gemmiparous leaves gradually reduced to the apex. Sexual condition dioicous. Gynoecia terminal, bracts in 1 pair, larger than sterile leaves, dorsal lobe $0.75-1.00 \times 0.35-0.65 \mathrm{~mm}$; ventral lobe $0.75-1.25 \times$ $0.40-0.65 \mathrm{~mm}$. Perianth oblong to obovate, truncate, dorsiventrally compressed, $1.50-1.75 \times 0.65-0.75 \mathrm{~mm}$, the upper part bend toward the ventral side, mouth entire to shortly and remotely lobulate.

Habitat: Decaying wood in broad-leaved and coniferous forests; 161-980 m alt.

Distribution: Primorsky Territory, Khabarovsk Territory, Sakhalin Province, Magadan Province.

Specimens examined: PRIMORSKY TERRITORY, South of Sikhote-Alin Range, Yu. A. Doronina 1.VIII.1976 (VBGI); SA-
KHALIN PROVINCE, Sakhalin Island, Vostochno-Sakhalinskiye Mts., VB S-53-8-06 (VBGI), Pilenga River., VB S-29-13-09 (VBGI); KHABAROVSK TERRITORY, Dusse-Alin Range, T.V. Petruk 24.VII.1994 (MHA, VBGI), 22.VII.1994 (VBGI), Gobilli River VB Kh-71-2-09 (VBGI), Solnechnyj Disrict VB Kh-5-2-07 (VBGI), Levaja Bureja River M.S. Ignatov 21.VIII.1997 G107330 (KPABG).

2. Scapania brevicaulis Tayl., London J. Bot. 5: 272, 1846. (Fig. 22, 52: 28)

Description: Plants 5.0-10.0 × 1.5-2.2 mm, ascending, green to brownish green. Stems sparsely branched, green near apex, brownish green below, dorsal surface green, ventral surface brownish green, cross section $0.15-0.20 \times$ $0.25-0.30 \mathrm{~mm}$, cortex cells thick-walled in 1-2 layers, 12.5 $15.0 \times 12.5-15.0 \mathrm{~mm}$ with brown walls; inner cells larger, thin-walled, $17.5-20.0 \times 17.5-20.0 \mathrm{~mm}$ with colorless walls. Rhizoids sparse to common, isolate, spreading at right angle with stem, colorless. Leaves imbricate; keel 0.6-0.7 of ventral lobe length, straight to slightly arched, ca. $45-80^{\circ}$ with stem axis at the middle part and up to $90^{\circ}-110^{\circ}$ at the end; dorsal lobe transversely inserted, not decurrent, broadly ovate to subrectangular, slightly erect $0.62-0.75 \times 0.25-0.37 \mathrm{~mm}, 0.6-0.7$ of ventral in size, ca. $45-60^{\circ}$ with stem axis, margin entire, apex obtuse to acute; ventral lobe transversely inserted, insertion line slightly arched, not decurrent, oblong to obovate, $0.75-0.100 \times$ $0.50-0.62 \mathrm{~mm},(0.65-0.75: 1)$, ca. $70-90^{\circ}$ with stem axis, margin entire, apex rounded to obtuse. Cells in the midleaf
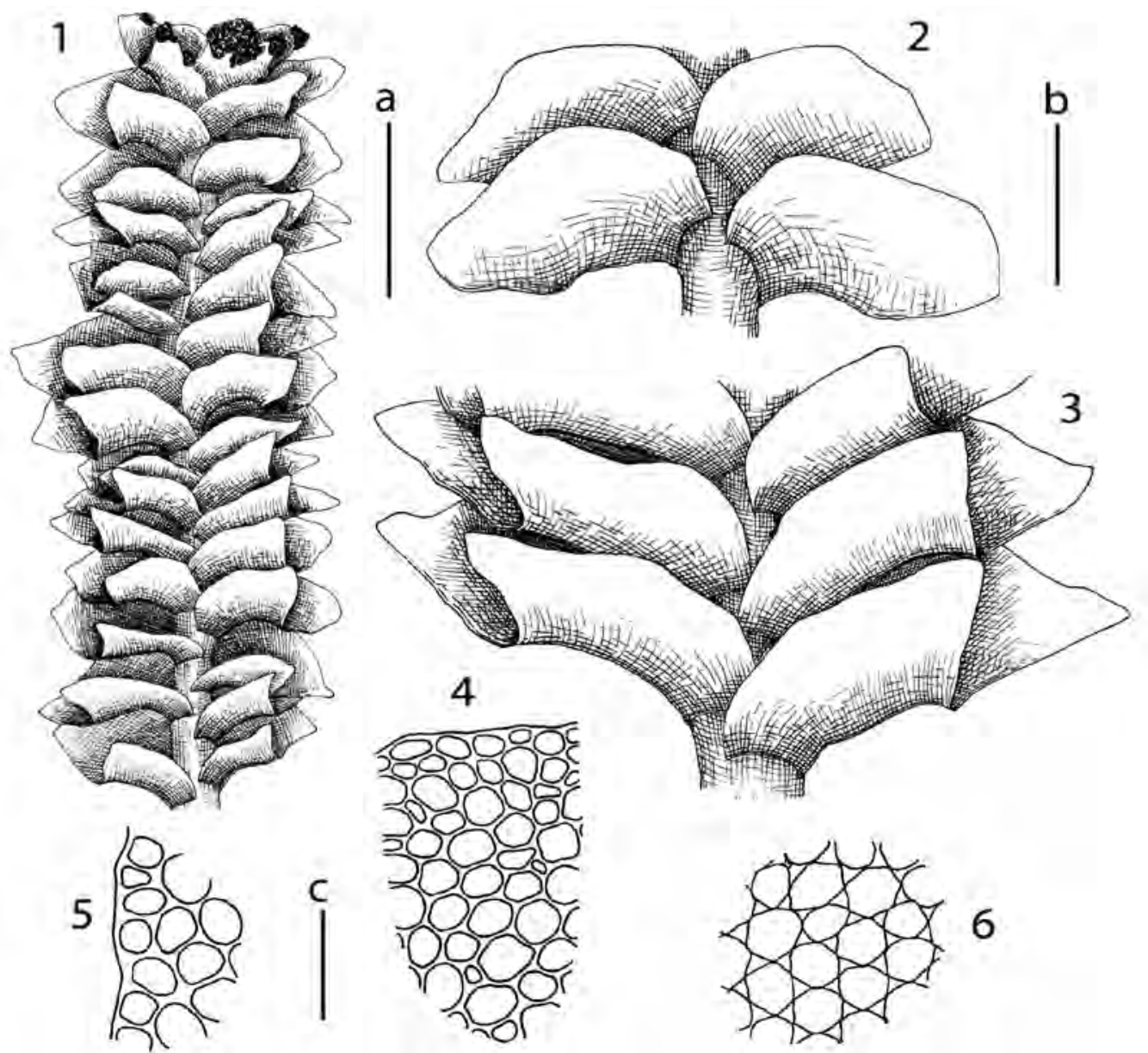

Figure 22 Scapania brevicaulis Tayl. 1 - habit, dorsal view; 2 - part of shoot, ventral view; 3 - part of shot, dorsal view; 4 -stem cross section fragment; 5 - leaf margin; 6 - midleaf cells. Scales: $\mathrm{a}-1 \mathrm{~mm}$, for $1 ; \mathrm{b}-500 \mu \mathrm{m}$, for 2,$3 ; \mathrm{c}-50$ $\mu \mathrm{m}$, for $4-6$. 
polygonal, $15.0-25.0 \times 12.5-15.0 \mathrm{~mm}$ with triangular trigones; near apex 12.5-15.0 × 10.5-15.0 mm, along margin thin-walled, with triangular trigones; at the base 25.0-30.0 $\times 17.5-20.0 \mathrm{~mm}$ with triangular trigones; cuticle slightly verrucose. Specialized asexual reproduction by gemmae in masses at apices of leaf-lobes, broadly elliptical, 15.0$17.5 \times 10.0-12.5 \mathrm{~mm}, 1(-2)$-celled, thick-walled, deep brown. Sexual condition dioicous. [Androecia intercalary, bracts in 2-3 pairs, 1-2 androus, antheridial stalk 1-seriate. Perianth moderately flatted, slightly contracted to mouth, dorsal surface with two deeply plicae, mouth essentially entire, merely sinuate to crenulate, occasionally remotely denticulate (Schuster, 1974).].

Habitat: Mineral and peaty soil in tundra zone and belt, basiphilous; $1000-1050 \mathrm{~m}$ alt.

Distribution: Kamchatka Territory, Magadan Province, Chukotka Province.

Comment: This species was previously placed in sect. Brevicaulis (Schuster 1974). However, characters of 1-celled gemmae and leaf shape refer the species to sect. Apiculatae. The close relation of S. brevicaulis with the latter was firstly supposed by Müller (1944). It seems to be superfluous to maintain both sections and it is preferable to unite them within sect. Apiculatae with the latter as priority name.

Specimens examined: MAGADAN PROVINCE, Khasynsky District, VB Mag-8-55-10 (VBGI); KAMCHATKA TERRITORY, Esso Settl. area, VB K-105-7-03 (VBGI).

3. Scapania carinthiaca J.B.Jack ex Lindb., Rev. Bryol. 7: 77, 1880. (Fig. 23, 24, 52: 25)

Description: Plants $2.5-3.5 \times 1.2-2.0 \mathrm{~mm}$, ascending to erect, green to greenish brown. Stems sparsely branched, dorsal surface green to greenish brown, ventral surface green to brown, cross section $0.18-0.21 \times 0.15-0.18 \mathrm{~mm}$, cortex cells thick-walled in 1-2 layers, $11.2-14.0 \times 11.2$ $14.0 \mu \mathrm{m}$ with brown walls; inner cells larger, thin-walled, 14.0-19.6 × 14.0-19.6 $\mu \mathrm{m}$ with colorless walls. Rhizoids numerous, colorless to pale brown. Leaves contiguous to imbricate; keel $0.4-0.6$ of ventral lobe length, straight to slightly arched, ca. $30-50^{\circ}$ with stem axis at the middle part and up to $110^{\circ}$ at the end; dorsal lobe transversely inserted, not decurrent, oblong-obovate, $1.00-1.25 \times 0.35-0.50 \mathrm{~mm}$, $0.45-0.55$ of ventral in size, ca. $30-50^{\circ}$ with stem axis, margin entire, apex acute; ventral lobe insertion line slightly arched, not decurrent, obliquely obovate, $1.00-1.50 \times 0.60$ $0.75 \mathrm{~mm},(0.5-0.6: 1)$, ca. $60-80^{\circ}$ with stem axis, margin entire with acute apex. Cells in the midleaf polygonal, $14.0-28.0 \times 14.0-24.6 \mu \mathrm{m}$ with triangular trigones; near apex 12.0-25.2 × 11.0-19.6 $\mu \mathrm{m}$; along margin 2-3 cell rows equally thick-walled; at the base $28.0-36.4 \times 14.0-22.4$ $\mu \mathrm{m}$ with small triangular trigones; cuticle weakly striolate. Specialized asexual reproduction by gemmae in masses at apices of leaf-lobes, elliptical, 11.2-14.0 × 8.4-11.2 $\mu \mathrm{m}$, 1 -celled, reddish brown, rarely occur. Sexual condition dioicous. Gynoecia bracts in one pair, slightly larger than sterile leaves, dorsal lobe $0.65-1.00 \times 0.50-0.75 \mathrm{~mm}$; ventral lobe $1.00-1.50 \times 0.40-1.00 \mathrm{~mm}$. Perianth oblong to obovate, truncate, weakly dorsiventrally compressed, $1.50-1.75 \times 0.70-0.80 \mathrm{~mm}$, in upper part bend toward the ventral side, mouth entire to shortly and remotely lobulate.

Habitat: Decaying wood in coniferous (Pinus, Picea and Abies) with admixture of broad-leaved trees forests; $550-850 \mathrm{~m}$ alt.

Distribution: Primorsky Territory, Khabarovsk Territory.
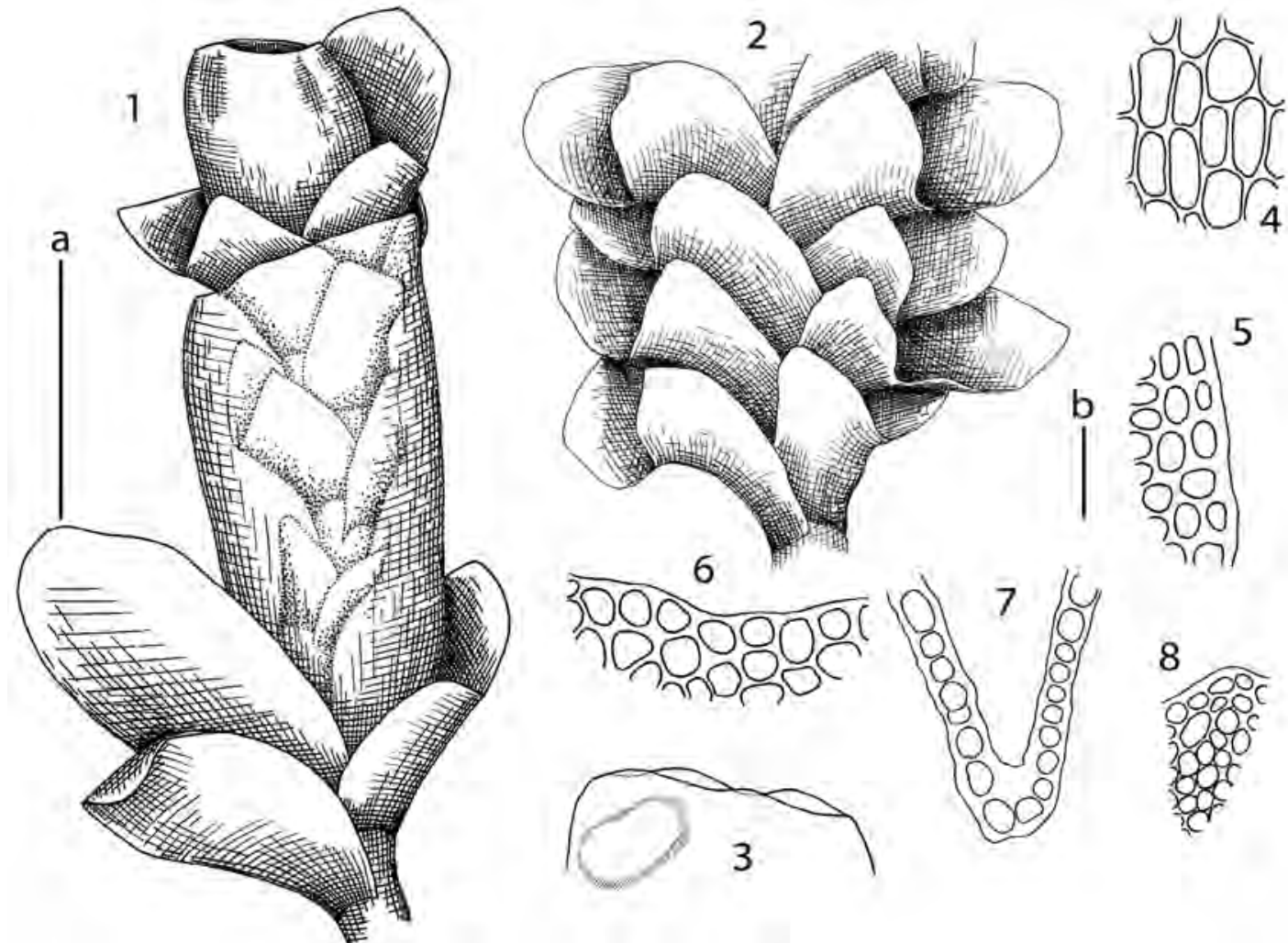

Figure 23 Scapania carinthiaca J. B. Jack ex Lindb. 1 - proliferation branch inside of perianth; 2 - part of shoot, dorsal view; 3 - pearianth mouth; 4 - ventral lobe basal cells; 5 - ventral lobe margin; 6 - perianth mouth; 7 - keel cross section; 8 - stem cross section, fragment. Scales: $\mathrm{a}-1 \mathrm{~mm}$ for $1-3 ; \mathrm{b}-50 \mu \mathrm{m}$, for $4-8$. 
Choi, Bakalin \& Sun

Table 3. Comparison of Species of Scapania sect. Apiculatae

\begin{tabular}{|l|c|c|c|}
\hline Characters & S. apiculata & S. brevicaulis & S. carintbiaca \\
\hline Margin cells of ventral lobe & thin-walled & thin-walled & 2-3 cells rows thick-walled \\
\hline Substrate preferences (general) & decaying wood & soil and peat & decaying wood \\
\hline Gemmiparous shoots & narrowed & not reduced & not reduced \\
\hline Ventral lobe as wide as long & $0.4-0.6$ & $0.6-0.7$ & $0.5-0.6$ \\
\hline Gemmae & reddish brown & deep brown & reddish brown \\
$11.2-14.0 \times 7.5-8.5$ & $15.0-17.5 \times 10.0-12.5$ & $8.4-11.2$ \\
\hline
\end{tabular}

Comments: 1 . This species was often misidentified as $S$. scandica or $S$. parvifolia in the Russian Far East. S. carinthiaca differs from two mentioned species in reddish brown, 1-celled gemmae and conspicuously thick-walled marginal cells of ventral lobe.

2. This species was previously placed in subgen. Scapaniella (Schuster 1974). However, reddish brown, 1-celled gemmae suit the sect. Apiculatae.

Specimens examined: PRIMORSKY TERRITORY, Lazovsky District, VB P-67-1-06, P-67-2-06, P-67-3-06, P-67-4-06 (VBGI), S.K Gambaryan 13.IX.1977 (VLA), Kavalerovsky District, S. K. Gambaryan 13.VI.1976 VLA-h2486 (VLA), 05.X.1981 VLA-h2485 (VLA), 15.X.1981 VLA-h2487 (VLA), Yasnaya River, S.K. Gambaryan
09.VIII.1994 VLA-2484, Chuguyevsky District, S.K. Gambaryan 27.VI.1976 VLA-h2488 (VLA); KHABAROVSK TERRITORY, Levaya River, S.K. Gambaryan 06.VI.1978 VLA-h2492 (VLA), Bolshekhekhtsirsky State Reserve, S.K.Gambaryan 18.IX.1982 VLA-h2491 (VLA), Okhotsk District, VB Kh-32-75-08 (VBGI).

SCAPANLA SECT. HYPERBORE A Váňa, Hentschel, Joch. Müll. \& Heinrichs, Phytokeys 10: 13, 2012

Description: Plants 10.0-70.0 $\times 2.0-3.0 \mathrm{~mm}$, ascending to erect, yellowish green to brownish green. Stems sparsely branched, pale brownish near apex, brown below, cross

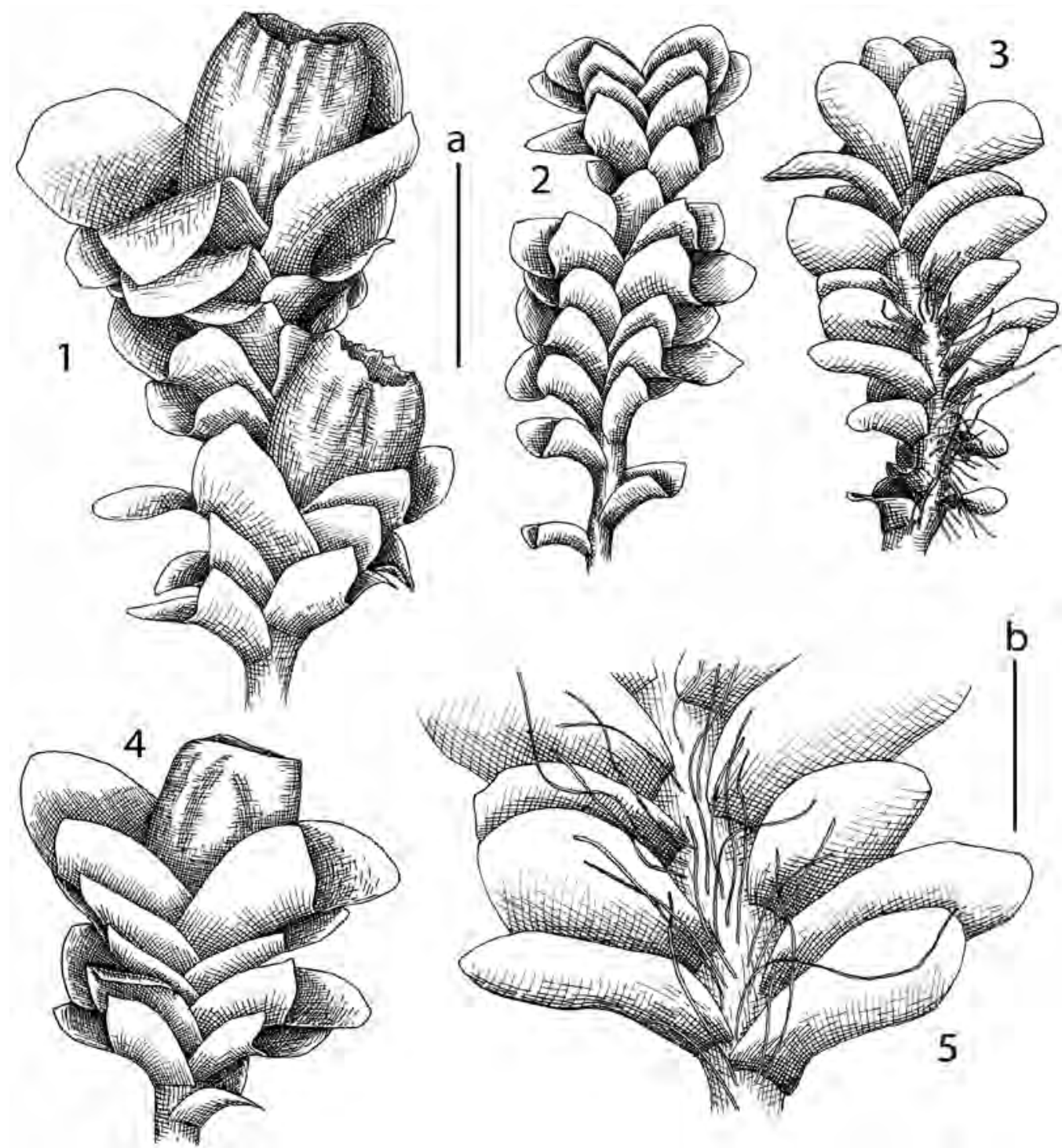

Figure 24 Scapania carinthiaca J. B. Jack ex Lindb. 1 - perianthous plant, dorsal view; 2 - habit, dorsal view; 3 habit, ventral view; 4 - perianthous plant, dorsal view; 5 - part of shoot, dorsal view. Scales: a $-1 \mathrm{~mm}$, for 1-4; $\mathrm{b}-500 \mu \mathrm{m}$, for 5 . 
section with cortex cells thick-walled in 1-2(-3) layers. Rhizoids sparse to numerous, fasciculate, spreading at right angle with stem, colorless. Leaves contiguous to imbricate; keel (0.1-)0.2-0.5 of ventral lobe length, usually lamellate-winged with wing 1-2(-3) cells wide; dorsal lobe transversely inserted, usually not decurrent, broadly obliquely subrectangular to obovate, arching over stem and beyond stem, slightly convex, margin entire, apex obtuse to acute; ventral lobe transversely inserted, insertion line arched, commonly not decurrent or sometimes shortly decurrent, 0.75-1.30: 1 as wide as long. Oil bodies 2-12 per cells, granulate, irregularly elliptical. Specialized asexual reproduction by gemmae in masses at apices of shoots or leaf-lobes, narrowly elliptical, 1-2-celled, reddish to brown at maturity. Sexual condition dioicous. Perianth oblong to obovate, dorsiventrally compressed, truncate, mouth entire to denticulate.

Species 4 (4 in the flora): North America, Eurasia (Table 4).

\section{Key to species of Scapania sect. Hyperborea in the Russian Far East}

1. Keel short, less than 0.25 of ventral lobe length, mostly strongly semicircularly arched; dorsal lobe ca. $0-30^{\circ}$ with stem axis ................ 4. S. paludicola.

1. Keel longer, more than 0.25 of ventral lobe length, slightly to strongly arched; dorsal lobe ca. $10-60^{\circ}$ with stem axis ................... 2. 2. Ventral lobe concave; marginal cells of ventral lobe $24.0-35.0 \mu \mathrm{m}$; gemmae 21.0-24.0 × 16.0-21.0 $\mu \mathrm{m}$............................... 3. S. tundrae. 2. Ventral lobe flat to convex; marginal cells of ventral lobe 14.0$22.0 \mu \mathrm{m}$; gemmae $14.0-16.0 \times 10.0-14.0 \mu \mathrm{m}$................................ 3 .

3. Gemmae 1-celled, brown; ventral lobe denticulate at apex; keel slightly to semicircularly arched, perianth strongly compressed, its mouth incurved to ventral side ......................................... 1. S. degenii. 3. Gemmae 2-celled, pinkish to reddish at maturity; ventral lobe entire; keel straight to slightly arched, perianth loosely compressed, straight. 2. S. byperborea.

\section{Key for gemmiparous plants}

1. Gemmae 1-celled, deep brown .... 1. S. degenii.

1. Gemmae 2-celled; reddish to brownish or pinkish at maturity 2. 2. Keel short, less than 0.25 of ventral lobe length, strongly semicircularly arched; dorsal lobe ca. $0-30^{\circ}$ with stem axis ..... 4. S. paludicola. 2. Keel longer, more than 0.25 of ventral lobe length, slightly to strongly arched; dorsal lobe ca. $10-60^{\circ}$ with stem axis ................... 3 . 3. Ventral lobe concave; marginal cells of ventral lobe $24.0-35.0$ $\mu \mathrm{m}$; gemmae 21.0-24.0 × 16.0-21.0 $\mu \mathrm{m}$........................ 3. S. tundrae. 3. Ventral lobe flat to convex; marginal cells of ventral lobe 14.0-22.0 $\mu \mathrm{m}$; gemmae 14.0-16.0 × 10.0-14.0 $\mu \mathrm{m}$.................. 2. S. byperborea

1. Scapania degenii Schiffn. ex Müll. Frib., Rabenh. Krypt.-Fl. 6(2): 497, 1915. (Fig. 25)

Description: Plants $20.0-40.0 \times 2.5-3.5 \mathrm{~mm}$, prostrate to ascending, yellowish green to fuscous-brown and brown. Stems sparsely branched, pale brownish near apex, deep brown below, cross section $0.20-0.25 \times 0.37-0.50 \mathrm{~mm}$, cortex cells thick-walled in 2-3 layers, $14.0-16.8 \times 8.4$ $14.0 \mu \mathrm{m}$ with brown walls; inner cells slightly larger, thinwalled, with triangular trigones, $16.8-22.4 \times 14.0-19.6 \mu \mathrm{m}$ with pale brownish to colorless walls. Rhizoids sparse to common, isolated, spreading at right angle with stem, colorless. Leaves densely imbricate; keel $0.3-0.5$ of ventral lobe length, usually lamellate-winged with wing 1-2 cells wide, slightly to semicircularly arched, ca. $20-45^{\circ}$ with stem axis near base and gradually incurved up to $135-150^{\circ}$ at the end; dorsal lobe transversely inserted, not decurrent, broadly reniform to obliquely ovate, arching over stem and beyond stem, strongly convex 1.00-1.50 × 1.25-1.50 $\mathrm{mm}, 0.50-0.75$ of ventral in size, ca. $30-60^{\circ}$ with stem axis, margin entire, apex obtuse; ventral lobe transversely inserted, insertion line arched, slightly decurrent, obliquely oblong to broadly ovate, convex to somewhat recurved, $1.50-2.00 \times 1.25-1.50 \mathrm{~mm},(0.8-1.0: 1)$, ca. $60^{\circ}-80^{\circ}$ with stem axis, margin entire at base to denticulate near apex, apex obtuse. Cells in the midleaf polygonal, 28.0-36.4 $\times$ 22.4-28.0 $\mu \mathrm{m}$ with convex to bulging trigones; near apex $14.0-19.6 \times 14.0-19.6 \mu \mathrm{m}$, with convex trigones; at the base $42.0-56.0 \times 28.0-33.6 \mu \mathrm{m}$ with convex to bulging trigones; cuticle slightly verrucose. Oil bodies 3-6 per cells, papillose to finely granulate, irregularly elliptic, $5.0-9.0 \times 4.0-5.5 \mu \mathrm{m}$ to spherical, $5.0-9.0 \times 3.5-5.5 \mu \mathrm{m}$. Specialized asexual reproduction by gemmae in masses at apices of leaf-lobes, elliptic to ovate, $14.0-16.8 \times 11.2-14.0 \mu \mathrm{m}, 1$-celled, brown. Sexual condition dioicous. Androecia intercalary, bracts in 3-5 pairs, similar to leaves but strongly inflated in the base, $1-3$ androus, body ca. $200.0 \times 140.0 \mu \mathrm{m}$, antheridial stalk 1-seriate, ca. $80.0-100.0 \mu \mathrm{m}$ long. Perianth strongly compressed, truncate mouth deflexed, mouth subentire to denticulate (Schuster, 1974).].

Habitat: Wet mossy tundras, peaty slopes to the stream in tundra zone and belt, rarely in Alnus crooked forests; basiphilous; $1100-1150 \mathrm{~m}$ alt.

Distribution: Kamchatka Territory, Magadan Province, Chukotka Province.

Specimens examined: KAMCHATKA TERRITORY, East Kamchatka, Kluchevskava group of volcano, I.V. Czernyadjeva 16.VIII.2004 (VBGI); MAGADAN PROVINCE, Khasynsky District, VB Mag-11-52-10, Mag-11-53-10 (VBGI), VB Mag-76-10, Mag-7-13-10 (VBGI), Omolon River, V.B. Dokuchayeva 11.VII.1979 (VBGI).

2. Scapania hyperborea Jørg., Forh. Vidensk.-Selsk. Kristiania 1894(8): 56, 1894. (Fig. 26)

Description: Plants 10.0-20.0 × 2.0-3.0 mm, prostrate to ascending, yellowish brown to fuscous brown. Stems sparsely branched, yellowish brown to deep brown, cross section $0.22-0.27 \times 0.25-0.32 \mathrm{~mm}$, cortex cells thick-walled in 1-2 layers, $14.0-22.4 \times 14.0-22.4 \mu \mathrm{m}$ with brown walls; inner cells slightly larger, thin-walled, with triangular trigones, 22.4-33.6 $\times 22.4-33.6 \mu \mathrm{m}$, walls pale brownish to colorless. Rhizoids common to numerous, fasciculate, spreading at right angle with stem, colorless. Leaves imbricate; keel $0.25-0.45$ of ventral lobe length, usually lamellate-winged with wing 1-2 cells wide, straight to slightly arched, ca. 20$50^{\circ}$ with stem axis at the basal part and gradually incurved up to $90-100^{\circ}$ to the end; dorsal lobe transversely inserted, not decurrent, obliquely reniform to broadly ovate, arching over stem, but not beyond it, strongly convex $0.75-1.10 \times$ $0.75-1.10 \mathrm{~mm}, 0.6-0.7$ of ventral in size, ca. $10-45^{\circ}$ with stem axis, margin entire, apex obtuse to acute; ventral lobe transversely inserted, insertion line arched, slightly decurrent, obliquely obovate to subrounded, slightly convex, $1.25-1.50 \times 1.00-1.25 \mathrm{~mm},(0.8-1.0: 1)$, ca. $50-80^{\circ}$ with 

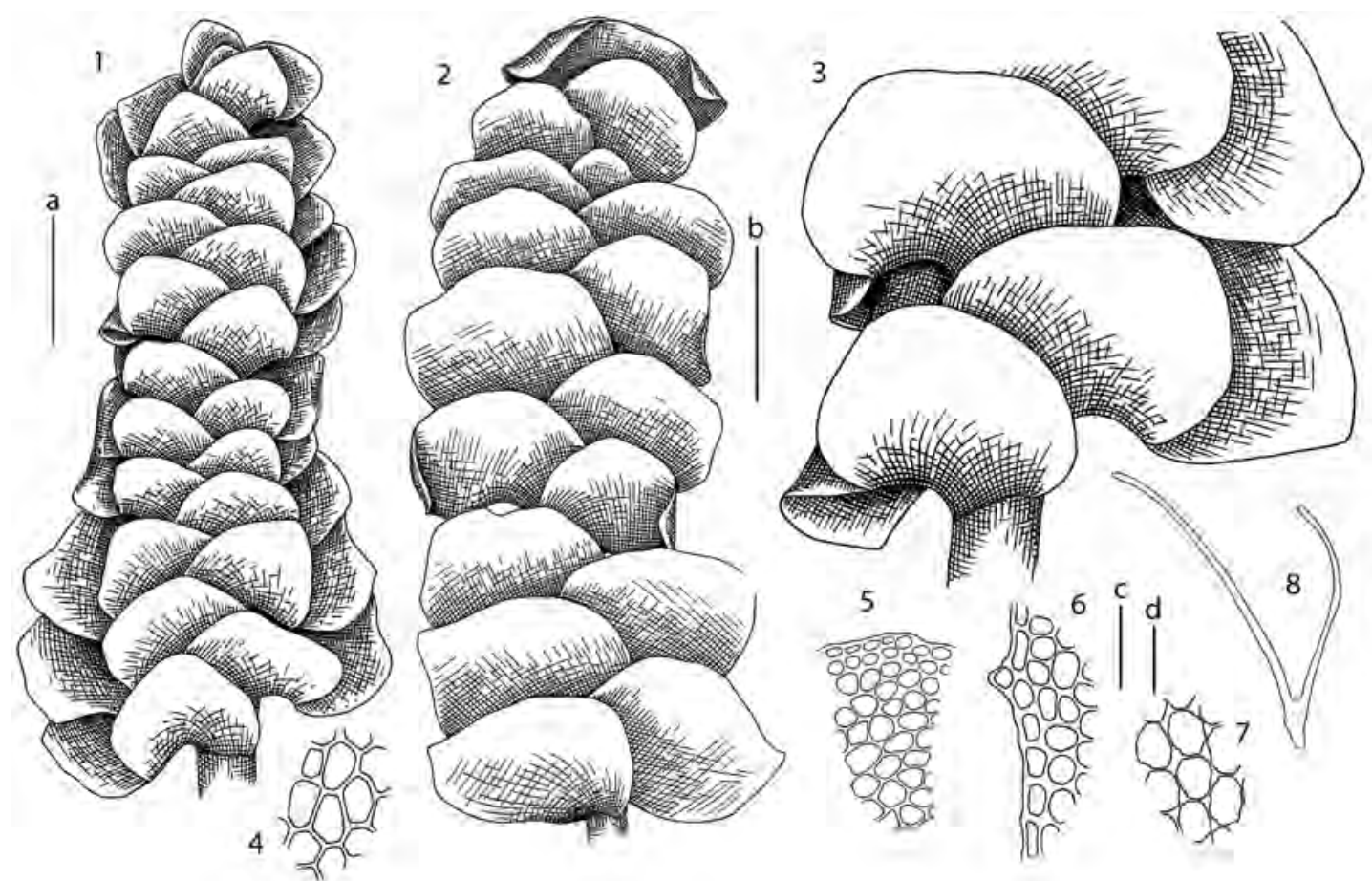

Figure 25 Scapania degenii Schiffn. ex Müll. Frib. 1 - habit, dorsal view; 2 - habit, ventral view; 3 - part of shoot, dorsal view; 4 - midleaf cells; 5 - stem cross section, fragment; 6 - leaf margin; 7 - midleaf cells; 8 - leaf cross section. Scales: $\mathrm{a}-1 \mathrm{~mm}$, for 1,$2 ; \mathrm{b}-500 \mu \mathrm{m}$, for 3 ; $\mathrm{c}-50 \mu \mathrm{m}$, for $4-7$; $\mathrm{d}-200 \mu \mathrm{m}$, for 8 .
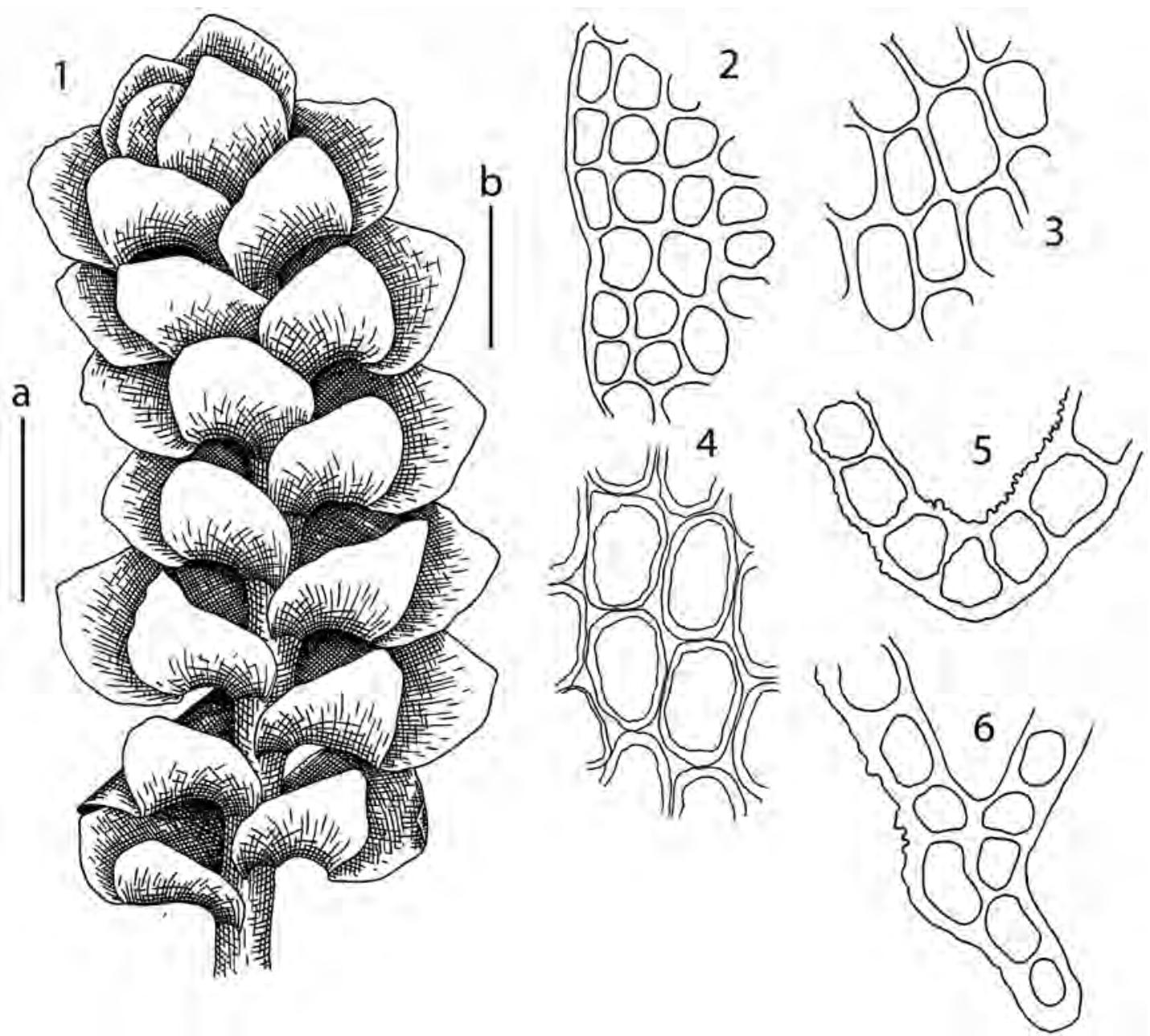

Figure 26 Scapania hyperborea Jørg. 1 - habit, dorsal view; 2 - leaf margin; 3 - midleaf cells; 4 - leaf cells near base; 5 , $6-$ keel cross section. Scales: $\mathrm{a}-1 \mathrm{~mm}$, for $1 ; \mathrm{b}-50 \mu \mathrm{m}$, for $2-6$. 
stem axis, margin entire, apex rounded to obtuse. Cells in the midleaf polygonal, 28.0-36.4 × 22.4-28.0 $\mu \mathrm{m}$ with convex to bulging trigones; near apex 16.8-22.4 × 19.6-25.2 $\mu \mathrm{m}$ with convex trigones; at the base $32.0-56.0 \times 22.4$ $28.0 \mu \mathrm{m}$ with convex to bulging trigones; cuticle distinctly papillose. Specialized asexual reproduction by gemmae in masses at apices of shoots, elliptical to ovate, 14.0-16.8 $\times$ 11.2-14.0 $\mu \mathrm{m}, 2$-celled, pinkish brown. Sexual condition dioicous. Perianth weakly compressed, or loosely 3-4-placatae, ca. $2.5 \times 1.0 \mathrm{~mm}$, truncate at mouth, mouth entire to very remotely denticulate.[Androecia intercalary, bracts in 2-4 pairs,3-5 androus. Perianth flatted, truncate at mouth, mouth subentire to remotely denticulate with slender 1-2(-3) celled teeth (Schuster 1974).].

Habitat: Wet hummocky sedge-moss communities, wet peaty roadside in tundra zone and belt; 14-1300 m alt.

Distribution: Sakhalin Province, Kamchatka Territory, Magadan Province, Chukotka Province.

Specimens examined: SAKHALIN PROVINCE, Shumshu Island, VB K-120-1-04, K-120-9-04 (VBGI); KHABAROVSK TERRITORY, Okhotsk District, VB Kh-23-7-08 (VBGI); KAMCHATKA TERRITORY, Commanders, Mednyj Island, VB K-68-2-04 (VBGI), Central Kamchatka, Belaya River, VB K-134-5-04 (VBGI), Okura pass, VB K-88-8-01 (VBGI), East Kamchatka, Ushkovsky volcano, VB K-42-1-03, K-42-11-03 (VBGI), VB K-52-1-03, K-54-2-03 (VBGI), Tolbachik volcano, I.V. Czernyadjeva 17.VIII.2003, 20.VIII.2003 (VBGI), North Kamchatka, Palana River Basin, VB K-37-40-03 (VBGI), VB K-38-1-03 (VBGI), Anadyrka River Basin, VB K-28-8-03 (VBGI).

3. Scapania tundrae (Arnell) H. Buch, Commentat. Biol. 3(1): 99, 1928. (Fig. 27, 52: 4)

Description: Plants $10.0-20.0 \times 2.0-2.5 \mathrm{~mm}$, ascending to erect, brown to pale reddish brown. Stems sparsely branched, deep brown, cross section $0.25-0.30 \times 0.37-0.42$ $\mathrm{mm}$, cortex cells thick-walled in 1-2 layers, 16.2-19.5 $\times$
13.0-16.2 $\mu \mathrm{m}$ with deep brown walls; inner cells larger, thinwalled, $24.3-32.4 \times 16.2-24.3 \mu \mathrm{m}$ with colorless walls. Rhizoids numerous, fasciculate, spreading at right angle with stem, colorless. Leaves contiguous; keel 0.22-0.55 of ventral lobe length, usually lamellate-winged with wing 1-2 cells wide, straight to slightly arched, ca. $20-30^{\circ}$ with stem axis at the basal part and gradually incurved up to $90-110^{\circ}$ to the end; dorsal lobe subtransversely inserted, not decurrent, obliquely rectangular to broadly ovate, convex, 0.75-1.00 $\times 0.37-0.62 \mathrm{~mm}, 0.55-0.75$ of ventral in size, ca. $45-60^{\circ}$ with stem axis, margin entire, apex obtuse to acute; ventral lobe transversely inserted, not decurrent, broadly obovate, strongly concave, $1.00-1.37 \times 0.87-1.00 \mathrm{~mm},(0.7-0.9$ : 1), ca. $70-80^{\circ}$ with stem axis, margin entire apex obtuse to acute, gemmiparous leaves denticulate to densely toothed. Cells in the midleaf polygonal, 32.4-40.5 × 16.2-34.3 $\mu \mathrm{m}$ with convex trigones; near apex 20.3-35.6 $\times 16.2-24.3 \mu \mathrm{m}$, thick-walled, trigones triangular, sometimes with hyaline row of one cell wide along margin; at the base 40.5-70.0 $\times$ 26.2-34.3 $\mu \mathrm{m}$ with convex trigones; cuticle slightly striolate. Specialized asexual reproduction by gemmae in masses at apices of leaves, broadly elliptical, 21.6-24.3 × 16.2-21.6 $\mu \mathrm{m}, 2$-celled, thick-walled, reddish brown. Sexual condition dioicous. Gynoecia terminal, bracts in one pair, slightly larger than sterile leaves, dorsal lobe $1.25-1.75 \times 0.62$ $0.75 \mathrm{~mm}$; ventral lobe $1.75-2.00 \times 0.75-1.00 \mathrm{~mm}$. Perianth oblong to obovate, dorsiventrally compressed, truncate, $1.5-2.0 \times 0.8-1.0 \mathrm{~mm}$, mouth dentate to ciliate, $1-5$ cells long, 1-2 cells wide.

Habitat: Wet mossy tundras, and peaty slopes in tundra zone and belt; $1000 \mathrm{~m}$ alt.

Distribution: Kamchatka Territory, Chukotka Province.

Specimens examined: KAMCHATKA TERRITORY, Central Kamchatka, Bystrinckij Nature Reserve, VB K-137-38-04 (VBGI).

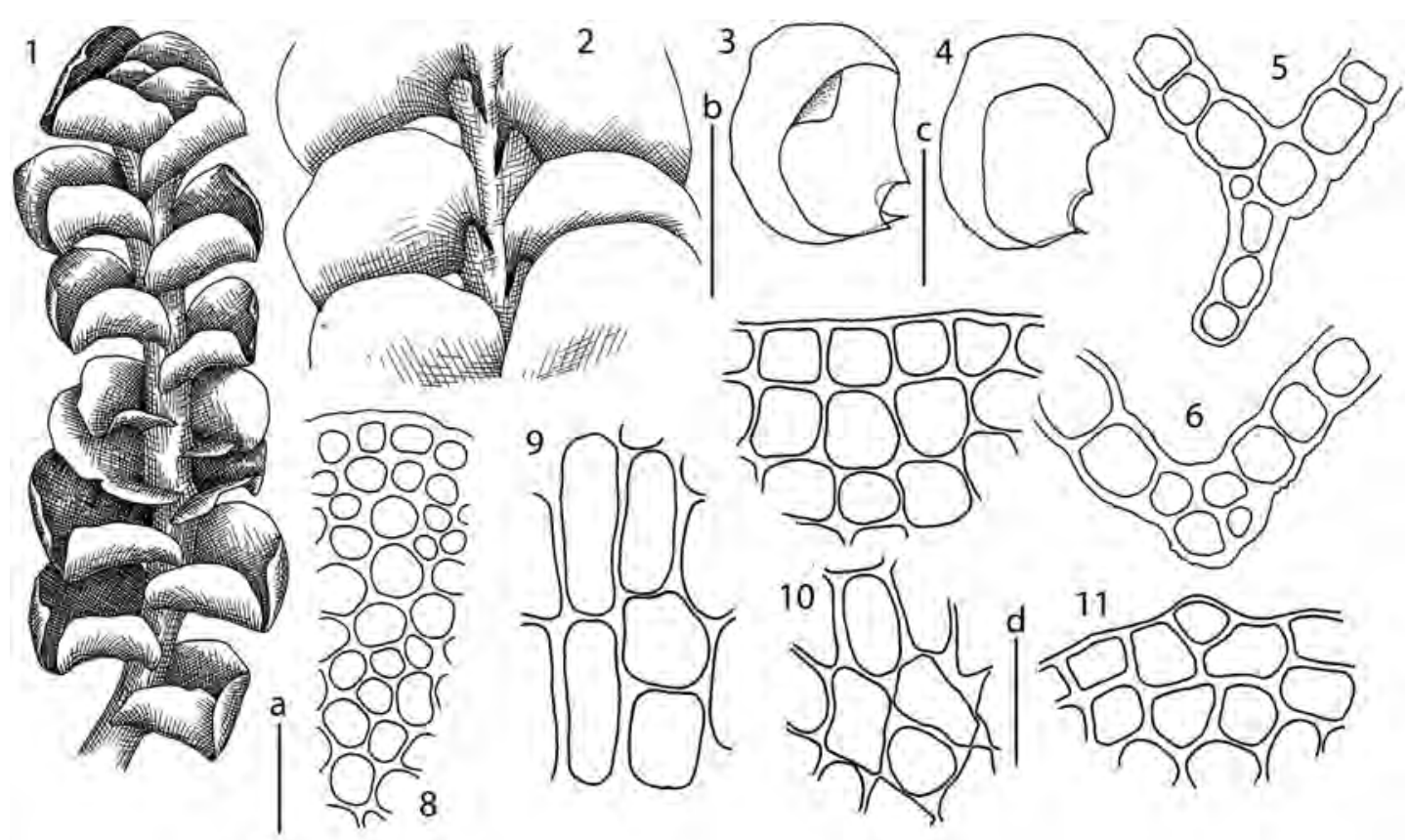

Figure 27 Scapania tundrae (Arnell) H. Buch. 1 - habit, dorsal view; part of shoot, ventral view; 3, 4- leaves; 5, 6-keel cross section; 7 - leaf margin; 8 - stem cross section, fragment; 9 - leaf base cells; 10 - midleaf cells; 11 - leaf apex. Scales: $\mathrm{a}-1 \mathrm{~mm}$, for $1 ; \mathrm{b}-1 \mathrm{~mm}$, for 2 ; $\mathrm{c}-1 \mathrm{~mm}$, for 3,4 ; $-50 \mu \mathrm{m}$, for $5-11$. 
Table 4. Comparison of Species of Scapania Sect. Hyperborea and Related Species from Scapania Sect. Curtae (S. irrigua)

\begin{tabular}{|c|c|c|c|c|c|}
\hline Characters & S. hyperborea & S. degenii & S. tundrae & S. paludicola & S. irrigua \\
\hline Keel of ventral lobe length & $0.25-0.45$ & $0.3-0.5$ & $0.25-0.55$ & $0.1-0.2(-0.3)$ & $0.25-0.50$ \\
\hline Keel arquation & $\begin{array}{c}\text { straight to slightly } \\
\text { arched }\end{array}$ & $\begin{array}{c}\text { slightly arched to } \\
\text { semicircularly arched }\end{array}$ & straight to arched & $\begin{array}{c}\text { strongly } \\
\text { semicircularly arched }\end{array}$ & slightly arched \\
\hline $\begin{array}{l}\text { Angle between stem and } \\
\text { dorsal lobe axis }\end{array}$ & $10-45^{\circ}$ & $30-60^{\circ}$ & $45-60^{\circ}$ & $0-30^{\circ}$ & $30-60^{\circ}$ \\
\hline Ventral lobe & flat to convex & flat to convex & concave & flat to convex & flat to slightly convex \\
\hline $\begin{array}{l}\text { Marginal cells of ventral } \\
\text { lobe, } \mu \mathrm{m}\end{array}$ & $16.8-22.4$ & $14.0-19.6$ & $24.3-35.6$ & $12.5-20.0$ & $11.2-19.6$ \\
\hline Margin of ventral lobe & entire & $\begin{array}{c}\text { entire to denticulate } \\
\text { near apex }\end{array}$ & $\begin{array}{l}\text { entire to sparsely } \\
\text { toothed }\end{array}$ & $\begin{array}{c}\text { entire to slightly } \\
\text { crispate }\end{array}$ & entire \\
\hline Gemmae & $\begin{array}{c}\text { 2-celled, } \\
\text { pinkish to reddish, } \\
15-16 \times 10-12\end{array}$ & $\begin{array}{c}\text { 1-celled, } \\
\text { brown, } \\
14-16 \times 11-14\end{array}$ & $\begin{array}{l}2 \text {-celled, } \\
\text { reddish brown, } \\
21-24 \times 16-21\end{array}$ & $\begin{array}{l}(1--) 2 \text {-celled, } \\
\text { reddish brown, } \\
15-20 \times 10-12\end{array}$ & $\begin{array}{c}\text { 2-celled, } \\
\text { green, } \\
\text { 19-22 } 2 \text { 8-11 }\end{array}$ \\
\hline
\end{tabular}

4. Scapania paludicola Loeske \& Müll. Frib., Rabenh. Krypt.-Fl. 6(2): 425, 1915. (Fig. 28, 29, 52: 13)

Description: Plants 30.0-70.0 $\times 2.5-3.0 \mathrm{~mm}$, ascending to erect, yellowish green to pale brownish green. Stems sparsely branched, yellowish green near apex and brownish green below, cross section $0.25-0.30 \times 0.40-0.45 \mathrm{~mm}$, cortex cells thick-walled in 1-2 layers, $7.5-12.5 \times 5.0-10.0$ $\mu \mathrm{m}$ with brown to fuscous brown walls; inner cells larger, thin-walled, with triangular trigones, 12.5-25.0 × 12.5$25.0 \mu \mathrm{m}$ with colorless walls. Rhizoids sparse near apex and common below, isolate to fasciculate and spreading at right angle with stem, colorless. Leaves contiguous to imbricate; keel $0.1-0.2$ of ventral lobe length, usually not winged, rarely lamellate-winged with wing 1-3 cells width, commonly strongly semicircularly arched, ca. $20-50^{\circ}$ with stem axis at the basal part and incurved up to $135-180^{\circ}$ at the end; dorsal lobe transversely to subtransversely inserted, insertion line arched, usually slightly decurrent for $0.2-0.3$ for stem wide, obliquely reniform to broadly cordate, arching over stem and sometimes far beyond stem, almost auriculate to circinate near base, convex, 0.8-1.2 $\times 1.2-1.3$ $\mathrm{mm}, 0.5-0.7$ of ventral in size, ca. $0-30^{\circ}$ with stem axis, margin entire, apex obtuse to acute; ventral lobe transversely inserted, insertion line arched, shortly decurrent for 0.2-0.3 of stem width, broadly ovate to cordate, sometimes slightly crispate, $1.2-1.4 \times 1.5-1.8 \mathrm{~mm},(1.0-1.3: 1)$, ca. $40^{\circ}-60^{\circ}$ with stem axis, margin entire, apex obtuse to acute. Cells in the midleaf polygonal, 25.0-45.0 $\times 15.0-25.0 \mu \mathrm{m}$ with convex trigones; near apex $12.5-30.0 \times 12.5-27.5 \mu \mathrm{m}$, thinwalled, with convex trigones; at the base 35.0-50.0 $\times 25.0$ $37.5 \mu \mathrm{m}$ with triangular to convex trigones; cuticle smooth to weakly verrucose. Oil bodies $5-10$ per cells, spherical to elliptical, $4.5-6.0 \times 3.5-4.5 \mu \mathrm{m}$, granulate. Specialized asexual reproduction by gemmae in masses at apices of shoots, elliptical to ovate, 1-2 celled: 1-celled 12.5-17.5 $\times 7.5-12.5 \mu \mathrm{m}, 2$-celled 15.0-20.0 × 10.0-12.5 $\mu \mathrm{m}$, pale reddish to reddish brown. Sexual condition dioicous. Gynoecia terminal, bracts in one pair, slightly larger than sterile leaves, dorsal lobe $1.2-1.3 \times 1.3-1.5 \mathrm{~mm}$; ventral lobe $1.8-2.0 \times 1.6-1.8 \mathrm{~mm}$. Perianth oblong to obovate, dorsiventrally compressed, truncate, $3.0-4.0 \times 1.4-1.8 \mathrm{~mm}$, mouth ciliate, 1-3 cells long, 1-2 cells wide.

Habitat: Wet mossy mats, peaty slopes to the streams; in tundra communities and oligotrophic bogs; rarely mossy banks of streams in coniferous forests; 8-1200 m alt.

Distribution: Primorsky Territory, Khabarovsk Territory, Amurskaya Province, Sakhalin Province, Kamchatka Territory, Magadan Province, Chukotka Province.

Specimens examined: AMURSKAYA PROVINCE: Urkana River, N. Prokhorov, O. Kuzeneva 06.VII.1910 (VBGI), Zeya River, Statonova 4.IX.1939 104 (VBGI); SAKHALIN PROVINCE, Sakhalin Island, Dagi Hot Springs, VB S-54-12-09, S-54-14-09 (VBGI), Okhinskyj Isthmus, VB S-52-13-09, S-52-26-09 (VBGI), Kunashir Island, VB K-51-1-06 (VBGI), VB K-63-10-06 (VBGI), Iturup Island, VB K-35-1-07 (VBGI), VB K-30-10-07, K-30-11-07 (VBGI), VB K-51-1-05, K-51-9-05, K-51-11-05, K-51-15-05, K-5228-05 (VBGI), Paramushir Island, VB K-77-4-04 (KPABG, VBGI), VB K-105-2-04 (VBGI), Shikotan Island, VB K-54-21-07(VBGI), Shumshu Island, VB K-125-42-04 (KPABG, VBGI), VB K-129-13-04 (KPABG, VBGI); KHABAROVSK TERRITORY, Okhotsk District, VB Kh-23-9-08, Kh-23-13-08 (VBGI), VB Kh-32-17-08 (VBGI), VB Kh-37-2-08 (VBGI); KAMCHATKA TERRITORY, Commanders, Mednyj Island, VB K-23-10-04 (KPABG, VBGI), Central Kamchatka, Agtam Mt., VB K-11-8-04 (VBGI), Eastern Kamchatka, Ushkovsky volcano, VB K-42-5a-03 (KPABG, VBGI), Western Kamchatka, O.A. Chernyagina ?.VII.1990 C125 (VBGI); MAGADAN PROVINCE, Khasynsky District, VB Mag-10-17-10, Mag-10-24-10 (VBGI), Omolon River, ? 21.VII.1979 24 (VBGI), Srednekansky District, VB Mag-14-62-10, Mag-14-69-10, Mag-14-76-10, Mag-14-79-10 (VBGI), VB Mag-16-13-10 (VBGI).

SCAPANLA SECT. COMPACTAE H. Buch, Soc. Sci. Fennica, Comm. Biol. 3(1): 101, 1928.

Scapania gruppe Compactae Müll. Frib. Rabenh. Krypt.Fl. 6(2): 511, 1915 nom. nud.

Description: Plants 10.0-50.0 × 2.5-4.0 mm, ascending to erect, brownish green to green. Stems sparsely branched, pale brown near apex, blackish brown below, cortex cells thick-walled in 1-3 layers. Rhizoids sparse, isolate, spreading at right angle with stem, colorless. Leaves contiguous to imbricate; keel $0.27-0.75$ of ventral lobe length, straight to arched; dorsal lobe subtransversely inserted, broadly obovate, strongly concave, $0.60-0.95$ of ventral in size, margin entire, apex rounded to obtuse; ventral lobe transversely inserted, insertion line arched for $0.3-0.4$ of stem wide, slightly decurrent, broadly obovate, strongly to slightly concave, 0.75-0.85: 1, margin entire, apex rounded to obtuse. Cells in the midleaf polygonal, with triangular to concave trigones; near apex thin-walled with concave trigones along margin; near base with concave trigones; cuticle smooth to weakly 

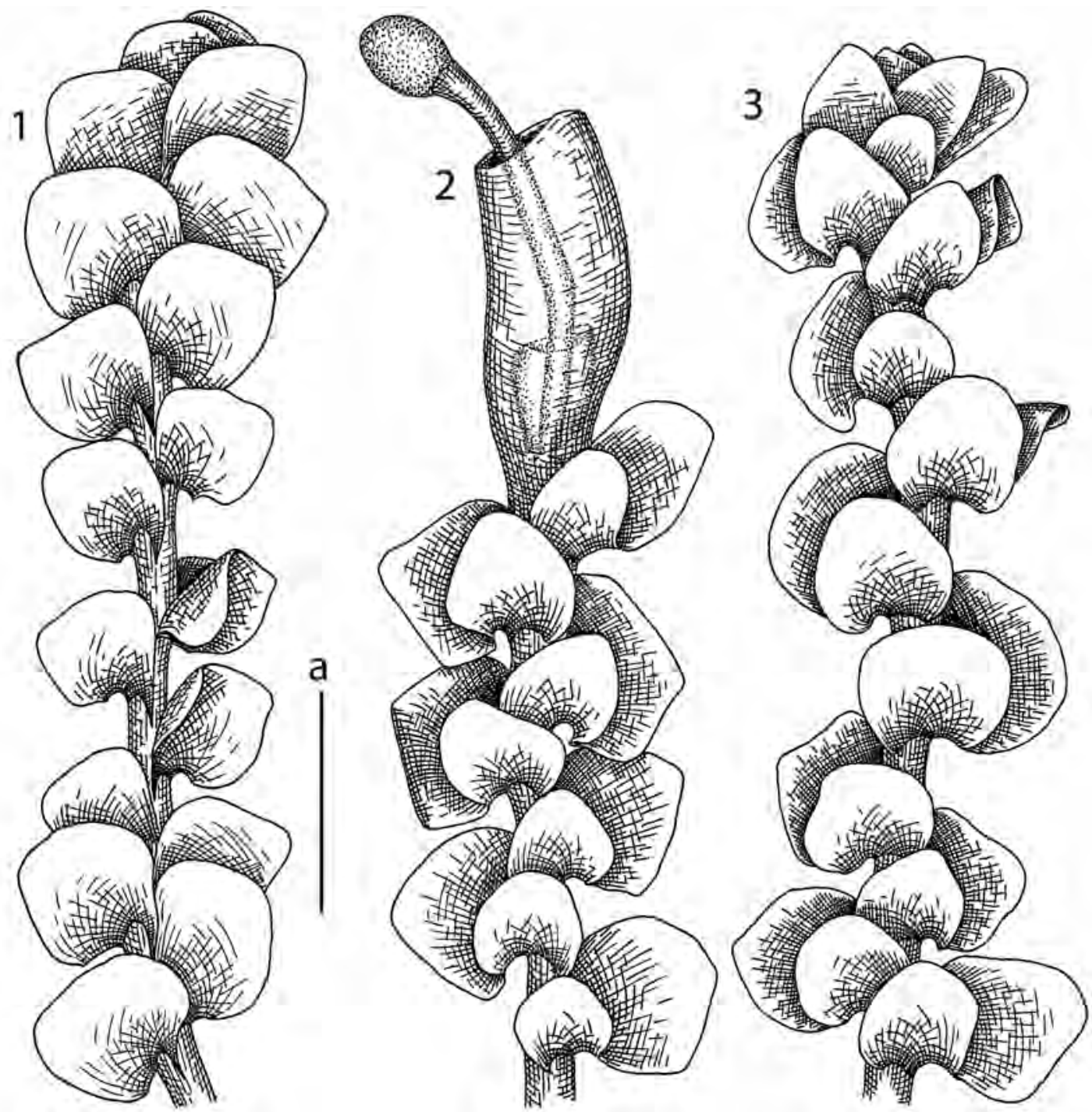

Figure 28 Scapania paludicola Loeske \& Müll. Frib. 1 - habit, ventral view; 2 - perianthous plant, dorsal view; 3 - habit, dorsal view. Scale: a $-2 \mathrm{~mm}$, for $1-3$.

verrucose. Specialized asexual reproduction by gemmae in masses at apices of shoots, elliptical, 2-celled, green to yellowish brown in full sun. Sexual condition monoicous (paroicous). Androecia below of perianth, bracts in 3-5 pairs, similar to leaves but slightly inflated in the base. Perianth oblong to obovate, weakly plicate, dorsiventrally compressed, truncate, mouth ciliate to lobulate.

Species 2 (1 in the flora): Eurasia, North America.

1. Scapania kaurinii Ryan, Bot. Not. 1889: 210, 1889. (Fig. 30).

Description: Plants $10.0-30.0 \times 2.5-3.7 \mathrm{~mm}$, ascending to erect, green to brownish green. Stems sparsely branched, pale brown near apex, blackish brown below, cross section $0.25-0.33 \times 0.38-0.45 \mathrm{~mm}$, cortex cells thick-walled in 1-2(-3) layers, $14.0-16.8 \times 8.4-14.0 \mu \mathrm{m}$ with brown walls; inner cells larger, thin-walled, 14.0-28.0 $\times 14.0-22.4 \mu \mathrm{m}$ with colorless walls. Rhizoids sparse, isolate, spreading at right angle with stem, colorless. Leaves contiguous to imbricate; keel $0.27-0.40$ of ventral lobe length, straight to arched, ca. $25-50^{\circ}$ with stem axis at the middle part and incurved up to $90-120^{\circ}$ at the end; dorsal lobe subtransversely inserted, insertion line slightly arched, broadly obovate, strongly concave $1.00-1.50 \times$ $0.75-1.00 \mathrm{~mm}, 0.6-0.8$ of ventral in size, ca. $15-50^{\circ}$ with stem axis, margin entire, apex rounded to obtuse; ventral lobe transversely inserted, insertion line arched, decurrent for $0.3-0.4$ of stem width, broadly obovate, strongly to sometimes slightly concave, $1.25-1.50 \times 1.00-1.25 \mathrm{~mm}$, (0.75-0.85:1), ca. $40-70^{\circ}$ with stem axis, margin entire, apex rounded to obtuse. Cells in the midleaf polygonal, 12.4-28.0 $\times 11.0-19.6 \mu \mathrm{m}$ with triangular trigones; near apex $11.2-19.0 \times 14.0-19.6 \mu \mathrm{m}$ with concave trigones; at the base $15.0-50.0 \times 13.0-28.0 \mu \mathrm{m}$ with concave trigones; cuticle smooth to weakly verrucose. Oil bodies $2-7$ per cells, spherical to ovate $4.0-8.5 \times 3.0-5.0 \mu \mathrm{m}$, finely papillose. Specialized asexual reproduction by gemmae in masses at apices of shoots, elliptical, 19.6-25.2 × 11.2-14.0 $\mu \mathrm{m}$, 2-celled, green. Sexual condition paroicous. Androecia just below female bracts, bracts in 3-5 pairs, similar to leaves but slightly inflated in the base, 1-3-androus, ca. $200.0 \times$ $150.0 \mu \mathrm{m}$, antheridial stalk 1-seriate, ca. $110.0-220.0 \mu \mathrm{m}$ 


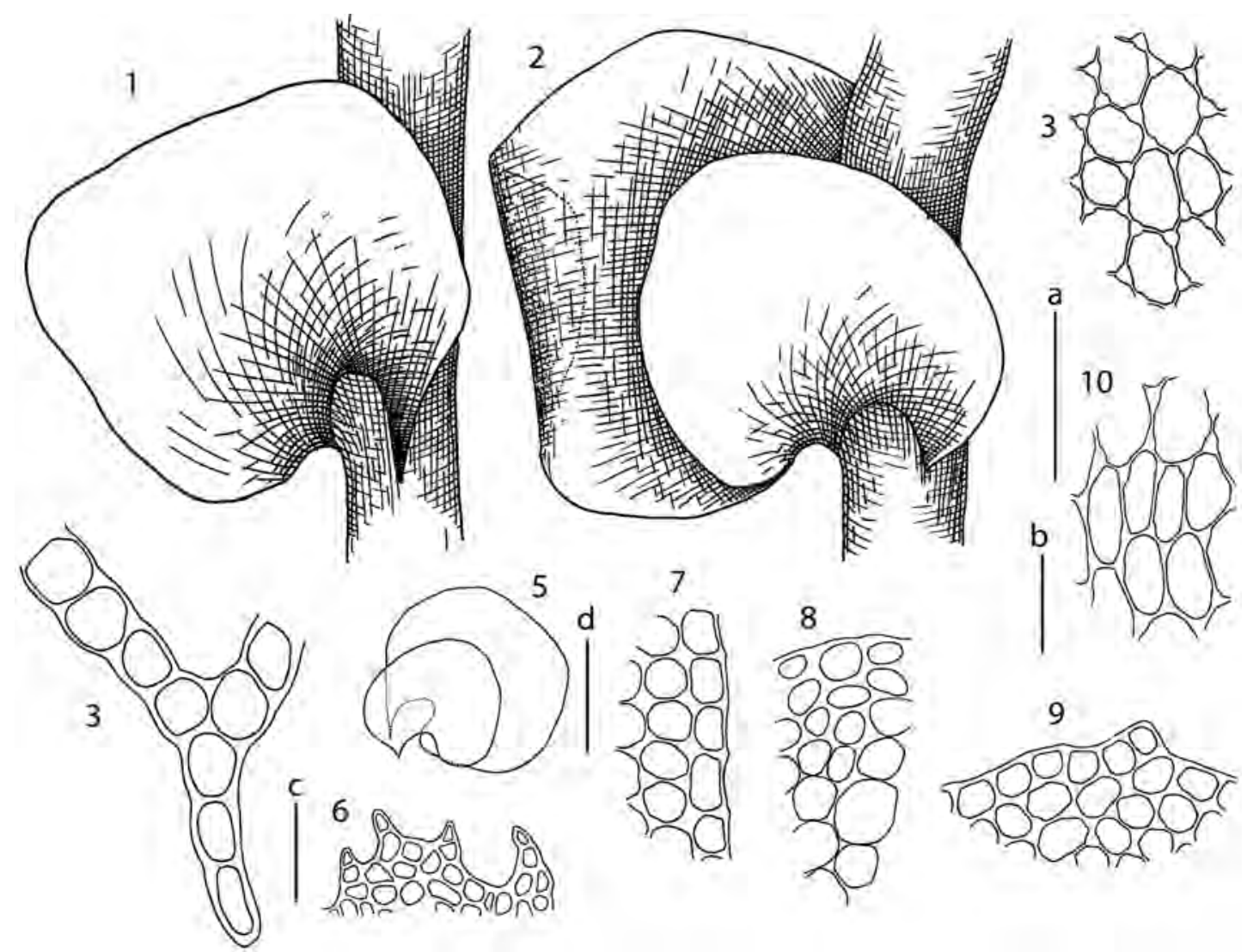

Figure 29 Scapania paludicola Loeske \& Müll. Frib. 1 - ventral lobe insertion; 2 - dorsal lobe insertion; 3 - midleaf cells; 4 - keel cross section; 5 - leaf; 6 - perianth mouth armature; 7 - leaf margin; 8 - stem cross section, fragment; 9 - leaf apex; 10 - leaf base cells. Scales: $\mathrm{a}-500 \mu \mathrm{m}$, for 1,$2 ; \mathrm{b}-40 \mu \mathrm{m}$, for $3,4,7-10 ; \mathrm{c}-80 \mu \mathrm{m}$, for 5 ; $\mathrm{d}-1 \mathrm{~mm}$, for 5 .
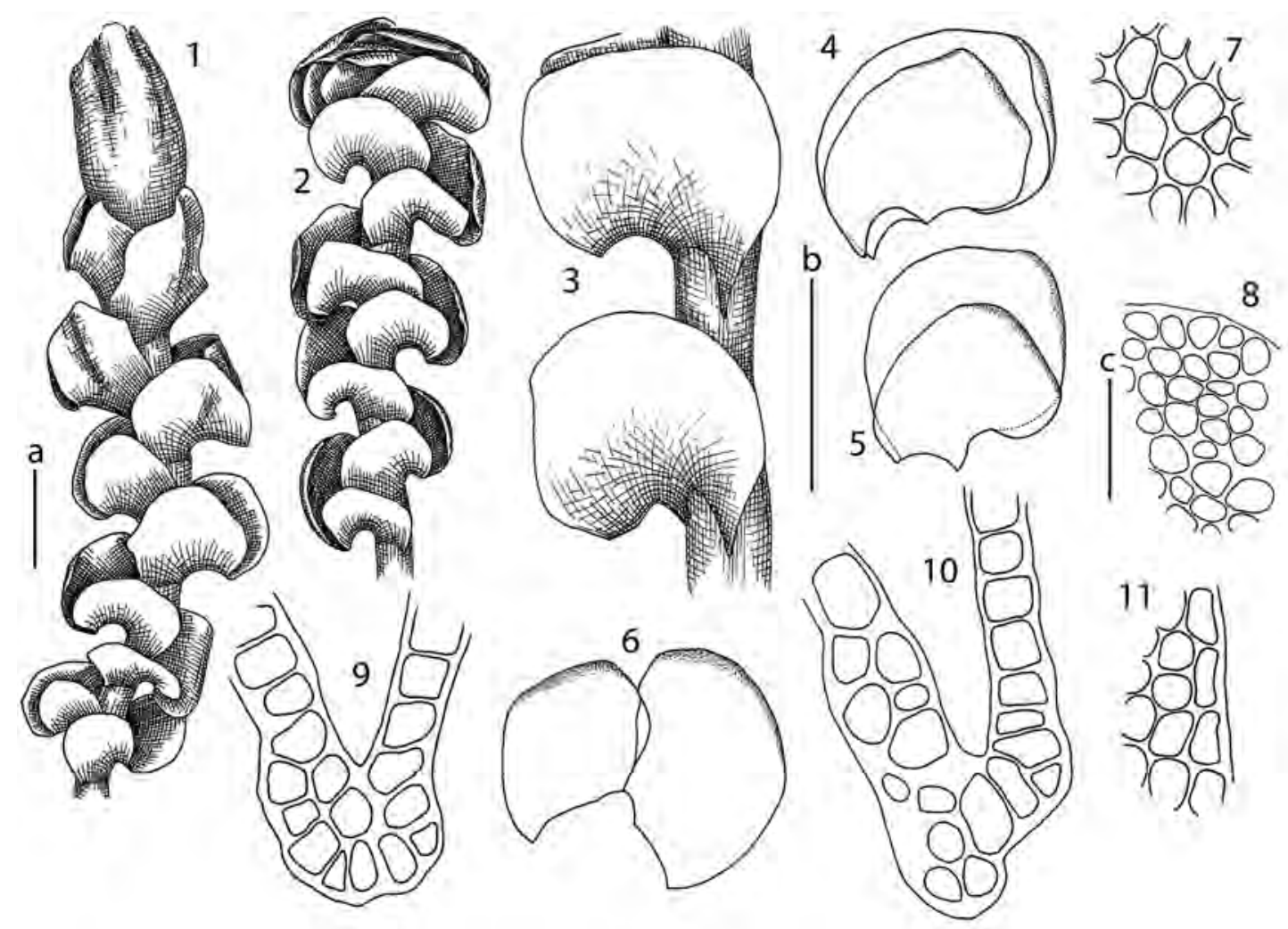

Figure 30 Scapania kaurinii Ryan 1 - perianthous plant, dorsal view; 2 - habit, dorsal view; 3 - part of shoot, ventral view; 4-6-leaves; 7 - midleaf cells, 8 - stem cross section, fragment; 9, 10 - keel cross section; 11 - leaf margin. Scales: $\mathrm{a}-1 \mathrm{~mm}$, for 1,$2 ; \mathrm{b}-1 \mathrm{~mm}$, for $3-6 ; \mathrm{c}-50 \mu \mathrm{m}$, for $7-11$. 
long. Gynoecia terminal, bracts in one pair, slightly larger than sterile leaves, dorsal lobe 1.3-1.6 $\times 0.8-1.1 \mathrm{~mm}$; ventral lobe 1.5-1.6 × 1.0-1.3 mm. Perianth oblong to obovate, weakly plicate, dorsiventrally compressed, truncate, 3.0-4.0 $\times 1.5-2.0 \mathrm{~mm}$, mouth ciliate to lobulate, with lobulae 1-5 cells long, 1-4 cells wide.

Habitat: Shaded rocks in stony fields or crevices in gravelly barrens fields in tundra belt; 1000-1400 m alt.

Distribution: Sakhalin Province, Kamchatka Territory, Magadan Province, Chukotka Province.

Specimens examined: SAKHALIN PROVINCE, Sakhalin Island, Nabilskij Range, VB S-61-7-09 (VBGI); KAMCHATKA TERRITORY, North Kamchatka, Palana River Basin, VB K-3714a-03, K-37-33-03 (KPABG, VBGI), Central Kamchatka, Esso Settl. area, VB K-109-9-03, K-109-10-03 (KPABG, VBGI), Bystrinckij Nature Reserve, VB K-137-24-04, K-137-32-04 (KPABG, VBGI).

SCAPANLA SECT. CUSPIDULIGERAE H. Buch, Soc. Sci. Fennica, Comm. Biol. 3(1): 125. 1928.

Description: Plants ca. $10.0-15.0 \times 2.0-2.5 \mathrm{~mm}$, prostrate to ascending or erect, green to greenish brown. Stems sparsely branched, green near apex, brownish below, dorsal surface greenish brown, ventral surface brown, cortex cells thick-walled in 1(-2) layers. Rhizoids numerous, fasciculate, spreading at right angle with stem, colorless. Leaves imbricate, comonly slightly undulate; keel $0.50-0.65$ of ventral lobe length; dorsal lobe transversely inserted, insertion line slightly arched, not decurrent, obliquely obovate, erect, $0.7-0.8$ of ventral in size; ventral lobe insertion line arched, decurrent for the stem width, obliquely obovate, $0.5-0.6: 1$ as wide as long, margin entire. Cells in the midleaf polygonal with triangular trigones; along margin 1-2 cell rows equally thick-walled near apex. Oil bodies $2-4(-6)$ per cells, spherical to irregularly spherical, granulate. Specialized asexual reproduction by gemmae in masses at apices of leaf-lobes, 2-celled, brown. Sexual condition dioicous. Androecia intercalary, bracts in 3-4 pairs, similar to leaves, but inflated in the base, 1 -androus.

Species 1 (1 in the flora): Eurasia, North America.

1. Scapania cuspiduligera (Nees) Müll.Frib., Lebermoose 472, 1915. (Fig. 31, 52: 27)

Description: Plants ca. $10.0-15.0 \times 2.0-2.5 \mathrm{~mm}$, prostrate to ascending or erect, green to greenish brown. Stems sparsely branched, green near apex, brownish below, dorsal surface greenish brown, ventral surface brown, cross

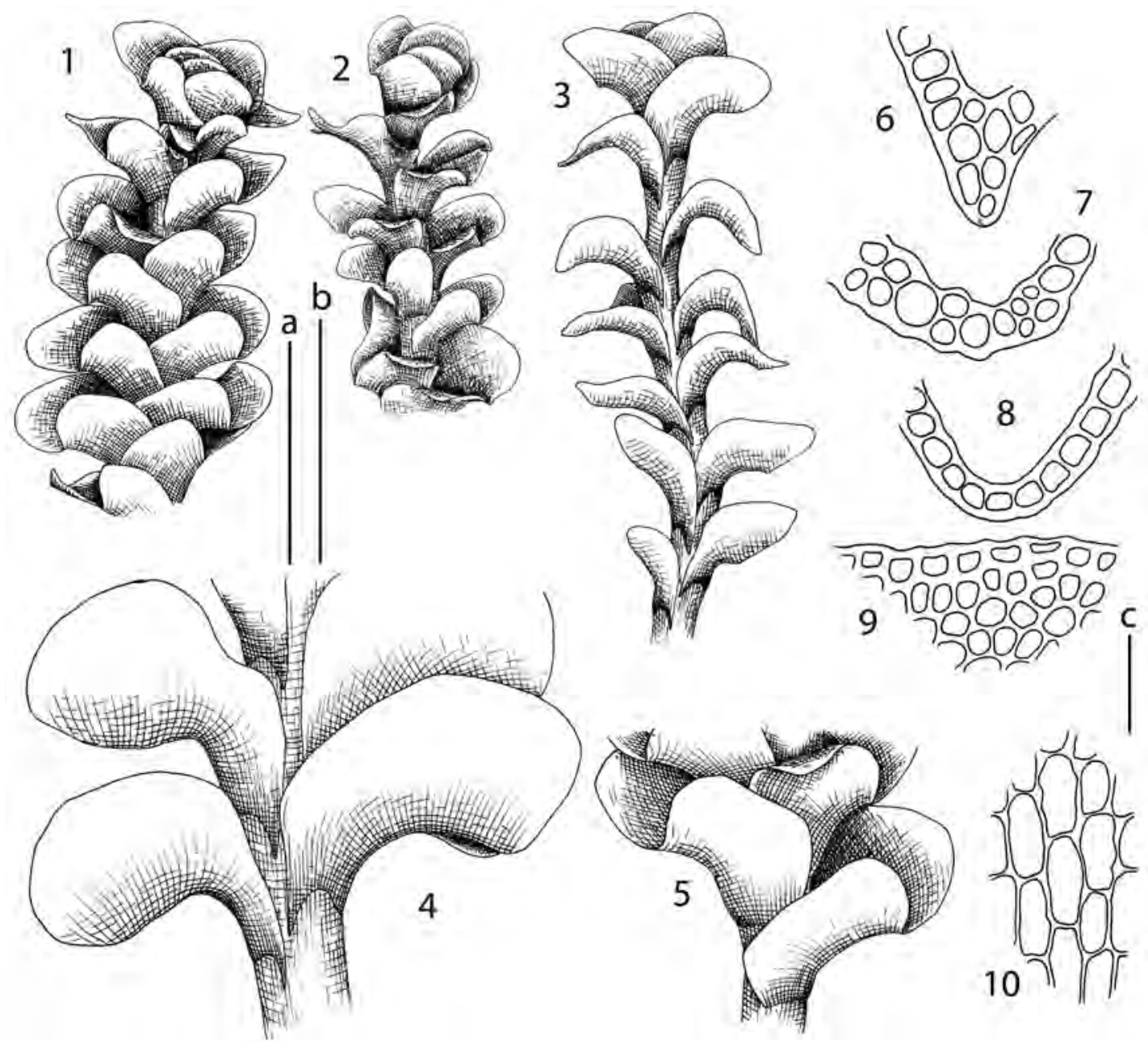

Figure 31 Scapania cuspiduligera (Nees) Müll. Frib. 1, 2 - habit, dorsal view; 3 - habit, ventral view; 4 - part of shoot, ventral view; 5 - part of shoot, dorsat view; 6-8 - kell cross section; 9 - leaf margin; 10 - leaf lobe basal cells. Scales: $\mathrm{a}-2 \mathrm{~mm}$, for $1-3 ; \mathrm{b}-1 \mathrm{~mm}$, for 4,$5 ; \mathrm{c}-50 \mu \mathrm{m}$, for $6-10$. 
section $0.25-0.30 \times 0.20-0.25 \mathrm{~mm}$, cortex cells thick-walled in 1(-2) layers, $10.0-17.5 \times 10.0-12.5 \mu \mathrm{m}$ with brown walls; inner cells larger, thin-walled, 12.5-25.0 × 12.5-25.0 $\mu \mathrm{m}$ with colorless walls. Rhizoids numerous, fasciculate, spreading at right angle with stem, colorless. Leaves imbricate, with sheathing base, somewhat slightly undulate at margin; keel $0.5-0.65$ of ventral lobe length, straight to slightly arched, ca. $45-50^{\circ}$ with stem axis at the middle part and gradually incurved up to $100^{\circ}$ at the end; dorsal lobe transversely inserted, insertion line slightly arched, not decurrent, obliquely obovate, erect, $0.75-1.00 \times 0.40-0.50$ $\mathrm{mm}, 0.7-0.8$ of ventral in size, ca. $30-50^{\circ}$ with stem axis, margin entire; ventral lobe insertion line arched, decurrent for the stem width, obliquely obovate, 1.0-1.2 × 0.5-0.6 $\mathrm{mm},(0.5-0.6: 1)$, margin entire, usually hyaline, at least near base. Cells in the midleaf polygonal, 18.0-33.6 × 16.8-23.4 $\mu \mathrm{m}$ with triangular trigones; near apex 10.4-19.0 $\times 14.0$ $20.0 \mu \mathrm{m}$, along margin with $1-2$ cell rows equally thickwalled; at the base $25.0-42.0 \times 16.8-22.4 \mu \mathrm{m}$, thick-walled; cuticle smooth. Oil bodies $2-4(-6)$ per cells, spherical to irregularly spherical, $4.0-6.0 \times 4.0-7.0 \mu \mathrm{m}$, granulate. Specialized asexual reproduction by gemmae in masses at apices of leaf-lobes, 25.2-28.0 × 11.2-14.0 $\mu \mathrm{m}, 2$-celled, brown. Sexual condition dioicous. Androecia intercalary, bracts in 3-4 pairs, similar to leaves, but inflated in the base, 1-androus, body ca. $140.0 \times 112.0 \mu \mathrm{m}$, antheridial stalk 1-seriate, ca. $90.0 \mu \mathrm{m}$ long.

Habitat: Cliffs or peaty banks of streams in wet mossy tundras or in Pinus pumila belt; generally basiphilous; 1050 $1263 \mathrm{~m}$ alt.

Distribution: Sakhalin Province, Kamchatka Territory, Magadan Province, Chukotka Province.

Specimens examined: SAKHALIN PROVINCE, Sakhalin Island, Nabil'sky Range, VB S-27-17-06 (VBGI); MAGADAN PROVINCE, Khasynsky District, VB Mag-8-29a-10, Mag-8-3310, Mag-8-45-10 (VBGI).

SCAPANLA SECT. UMBORSAE H. Buch, Soc. Sci. Fennica, Comm. Biol. 3(1): 120, 1928.

Description: Plants 5.0-15.0 × 1.2-2.0 mm, ascending to erect, yellowish green to pale reddish brown. Stems sparsely branched, yellowish green near apex, pale reddish brown below, cortex cells in cross section thick-walled in 2-4 layers. Rhizoids sparse, isolate, spreading at right angle with stem, colorless. Leaves contiguous to imbricate; keel $0.25-0.45$ of ventral lobe length, usually lamellate-winged, with wing 2-3 cells wide, straight to slightly arched at the end; dorsal lobe transversely inserted, not decurrent, narrowly ovate, $0.45-0.55$ of ventral in size, margin denticulate, apex acute; ventral lobe transversely inserted, insertion line arched for 1.0-1.2 of stem wide, decurrent, narrowly ovate, strongly recurved, margin denticulate, apex acute. Cells in the midleaf polygonal with triangular trigones; near apex rectangular with triangular trigones; cuticle distinctly striolate. Specialized asexual reproduction by gemmae in masses at apices of shoots, elliptical, 2-celled, reddish. Sexual condition dioicous. Androecia intercalary, bracts in 3-5 pairs. Gynoecia terminal, bracts in one pair, slightly larger than sterile leaves. Perianth oblong to obovate, dorsiventrally compressed, truncate, the upper part bend toward to ventral side, mouth smooth.

Species 1 ( 1 in the flora): Eurasia, North America.

1. Scapania umbrosa (Schrad.) Dumort., Recueil Observ. Jungerm. 14, 1835. (Fig. 32, 52: 3)

Description: Plants 5.0-15.0 × 1.2-2.0 mm, ascending to erect, yellowish green to pale reddish brown. Stems sparsely branched, yellowish green near apex, pale reddish brown below, cross section $0.15-0.25 \times 0.25-0.30 \mathrm{~mm}$, cortex cells thick-walled in 2-4 layers, 11.3-16.2 × 8.1-11.3 $\mu \mathrm{m}$ with brown walls; inner cells larger, thin-walled, 16.2$24.3 \times 13.0-21.1 \mu \mathrm{m}$ with colorless to pale brownish walls. Rhizoids sparse, isolate, spreading at right angle with stem, colorless. Leaves contiguous to imbricate; keel $0.25-0.45$ of ventral lobe length, usually lamellate-winged with wing 2-3 cells wide, ca. $25-45^{\circ}$ with stem axis at the middle part and up to $70-80^{\circ}$ at the end; dorsal lobe transversely inserted, not decurrent, narrowly ovate, $0.50-1.00 \times 0.37-0.50 \mathrm{~mm}$, $0.45-0.55$ of ventral in size, ca. $20-40^{\circ}$ with stem axis, margin denticulate, apex acute; ventral lobe transversely inserted, insertion line arched, decurrent for 1.0-1.2 of stem wide, narrowly ovate, strongly recurved, $0.75-1.50 \times 0.50$ $0.75 \mathrm{~mm}(0.50-0.65: 1)$, ca. $45-70^{\circ}$ with stem axis, margin denticulate, apex acute. Cells in the midleaf polygonal, 21.3-32.4 × 16.2-24.3 $\mu \mathrm{m}$ with triangular trigones; near apex rectangular $12.0-16.2 \times 13.0-19.5 \mu \mathrm{m}$ with triangular trigones; at the base $48.6-64.8 \times 16.2-29.3 \mu \mathrm{m}$ with convex trigones; cuticle distinctly striolate. Specialized asexual reproduction by gemmae in masses at apices of shoots, elliptical, 16.2-21.1 × 8.1-9.7 $\mu \mathrm{m}, 2$-celled, reddish. Sexual condition dioicous. Androecia intercalary, bracts in 3-5 pairs, similar to leaves, but slightly inflated in the base, 1-3 androus, body ca. $130.0 \times 100.0 \mu \mathrm{m}$, antheridial stalk 1-seriate, ca. 130.0-160.0 $\mu \mathrm{m}$ long. Gynoecia terminal, bracts in one pair, slightly larger than sterile leaves, dorsal lobe $1.25-1.50 \times 0.75-0.87 \mathrm{~mm}$; ventral lobe $1.50-1.75 \times$ $0.87-1.00 \mathrm{~mm}$. Perianth oblong to obovate, dorsiventrally compressed, truncate, the upper part bend towards the ventral side, $2.5-3.0 \times 1.5 \mathrm{~mm}$, mouth smooth.

Habitat: Fine-grained soil in wet roadsides in dark coniferous forest belt; $60-1400 \mathrm{~m}$ alt.

Distribution: Sakhalin Province, Kamchatka Territory.

Specimens examined: SAKHALIN PROVINCE, Kunashir Island, VB K-53-16-06 (VBGI); KAMCHATKA TERRITORY, Central Kamchatka, Bystrinskij Nature Reserve, VB K-137-7-04, K-137-8a-04 (KPABG, VBGI).

\section{SCAPANLA SECT. SCAPANIA}

Scapania sect. Undulatae H. Buch, Soc. Fennica, Comm. Biol. 3(1): 135, 1928.

Scapania sect. Rufidulae R.M. Schust. ex Grolle. Feddes Repert. 87: 265, 1976.

Description: Plants $10.0-50.0 \times 2.0-4.0 \mathrm{~mm}$, ascending to erect, green to reddish green in upper part, to reddish black below. Stems frequently branched, green near apex, reddish black in the middle, cross section with thick-walled cortex cells in 1-3(-4) layers. Rhizoids sparse to common, colorless, isolate, decurrent along stem to spreading at right angle from the 

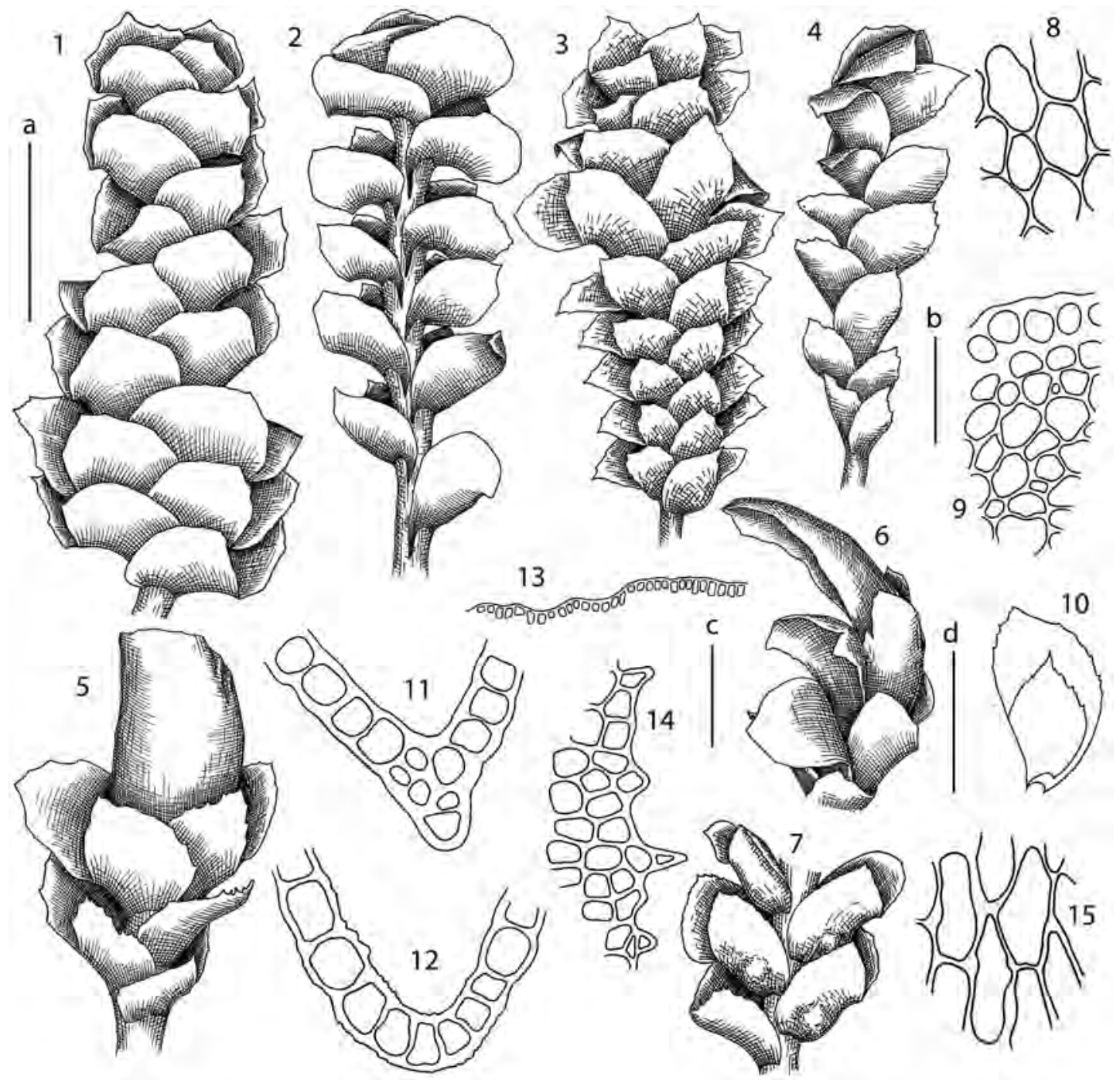

Figure 32 Scapania umbrosa (Schrad.) Dumort. 1,3 - habit, dorsal view; 2, 4- habit, ventral view; 5, 6- upper part of perianthous plant; 7 - part of androecious plant; 8 - midleaf cells; 9 - stem cross section, fragment; 10 - leaf; 11, 12 - keel cross section; 13 - perianth mouth armature, fragment; 14 - leaf margin; 15 - leaf base cells. Scales: a $-1 \mathrm{~mm}$, for $1-7$; b $-50 \mu \mathrm{m}$, for $8,9,11,12,14,15 ; \mathrm{c}-100 \mu \mathrm{m}$, for 13 ; d $-1 \mathrm{~mm}$, for 10 .

stem. Leaves contiguous to imbricate; keel $0.2-0.7$ of ventral lobe length, usually lamellate-winged with wing 1-3 cells wide; dorsal lobe transversely inserted, broadly ovate to rounded or rectangular, arching over stem and beyond stem, $0.25-0.85$ of ventral in size; ventral lobe transversely inserted, insertion line arched for 1.0-2.0 of stem width, long decurrent, obliquely obovate, 0.5-1.2: 1 as wide as long. Cells in the midleaf oblong to rectangular, with concave trigones; along margin near apex with 1-3 cell rows equally thick-walled; at the base with concave trigones; cuticle slightly striolate to verrucose. Oil bodies (2-)5-8(-10) per cells, granulate, spherical to elliptical, brown. Specialized asexual reproduction by gemmae in masses at apices of shoots, elliptical to ovate, (1-)2-celled, pale green to reddish brown. Sexual condition dioicous. Androecia intercalary, bracts in 3-5 pairs, similar to leaves but inflated in the base, antheridial stalk 1-seriate. Gynoecia terminal, bracts in one pair, slightly larger than sterile leaves. Perianth oblong to obovate, dorsiventrally compressed, truncate, mouth entire to denticulate.

Comments: Section Rufidulae was described on the basis of strongly dentate basal part of the both lobes (Schuster 1951).
However, in other features, such as greenish 2-celled gemmae, distinctly decurrent ventral lobe, etc., this section does not differ from sect. Scapania. Due to the strong variability in dentation features, displayed by $S$. rufidula and $S$. spitsbergensis, on the one hand, and S. subalpina, S. uliginosa, etc., on the other hand, i. e. taxa of the both sect. Scapania s. str. and sect. Rufidulae, we treat both names as synonymous, with the former having priority.

Species ca. 8 (7 in the flora): North America, Eurasia (Table 5).

\section{Key to the species of Scapania sect. Scapania} in the Russian Far East

1. Leaves and keel with margins entire to denticulate-dentate ...... 2.

2. Dorsal lobe distinctly decurrent ................. 3

3. Keel strongly semicircularly arched, $0.10-0.25$ of ventral lobe length, dorsal lobe $0.55-0.75$ of ventral lobe .................... 1. S. paludosa. 3. Keel moderately arched, $0.22-0.30$ of ventral lobe length, dorsal lobe $0.25-0.5$ of ventral lobe ........................................... 2. S. uliginosa.

2. Dorsal lobe not decurrent ..

... 4.

4. Leaves with marginal 1-3 cell rows equally to subequally thickwalled; gemmae 2-celled, pale green; plant usually green to reddish

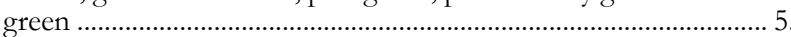
5. Dorsal lobe $0.3-0.6$ of ventral lobe size; keel $0.24-0.40$ of vent- 


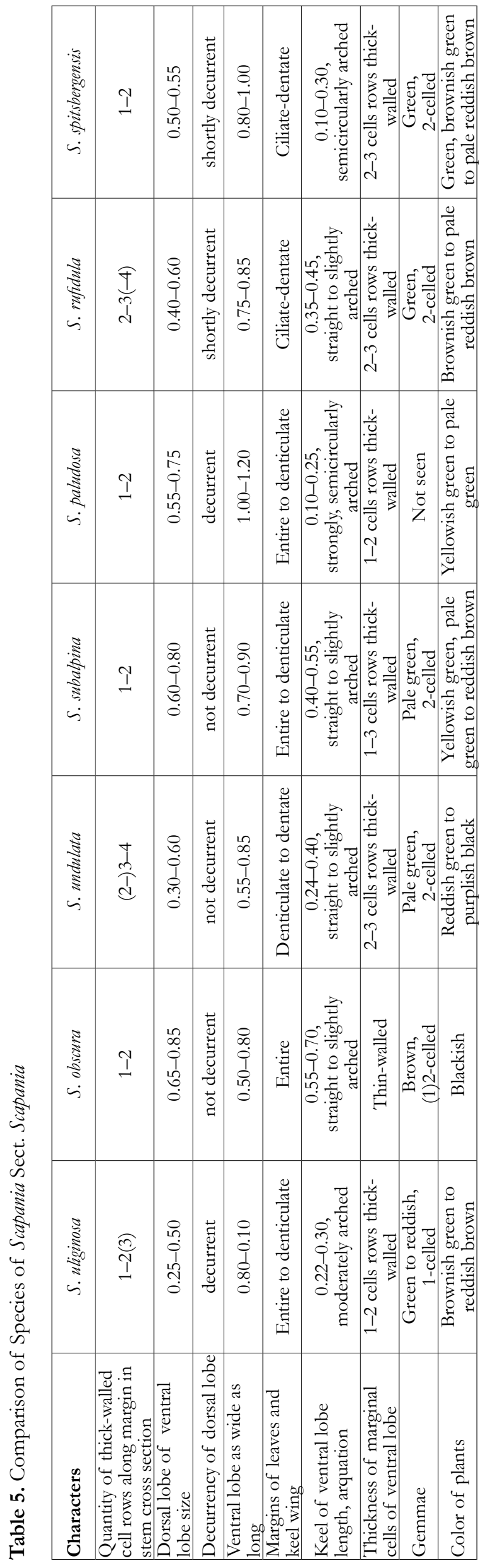

ral lobe length; stem in cross section with 3-4(-5) layers of thickwalled cells along margin .................................................. 3. S. undulata.

5. Dorsal lobe $0.6-0.7$ of ventral lobe size; keel $0.40-0.55$ of ventral lobe length; stem cross section with 1-2 layers of thick-walled cells along margin ...................................................................... 4. S. subalpina. 4. Leaves with marginal cells thin-walled; gemmae (1-)2-celled, brown; plants usually blackish ............................................... 5. S. obscura. 1. Leaves and keel with margins ciliate-dentate..... ... 6. 2. Keel straight to slightly arched, $0.35-0.45$ of ventral lobe length; dioicous ........................................................................... 6. S. rufidula. 2. Keel semicircularly arched, $0.1-0.3$ of ventral lobe length; paroicous ....................................................................... 7. S. spitsbergensis.

1. Scapania paludosa (Müll. Frib.) Müll. Frib., Mitt. Bad. Bot. Vereins 182-183: 287, 1902. (Fig. 33)

Description: Plants $30.0-50.0 \times 3.5-4.8 \mathrm{~mm}$, ascending to erect, yellowish green to pale green. Stems sparsely branched, yellowish green near apex and brownish green below, cross section $0.40-0.45 \times 0.38-0.45 \mathrm{~mm}$, cortex cells slightly thick-walled in 1-2 layers, $10.0-15.0 \times 7.5-10.0 \mu \mathrm{m}$ with brown walls; inner cells larger, thin-walled, with concave trigones, $17.5-37.5 \times 17.5-37.5 \mu \mathrm{m}$, walls colorless. Rhizoids sparse, colorless. Leaves contiguous to imbricate; keel 0.10 $0.25(-0.30)$ of ventral lobe length, usually winged, with wing $4-8$ cells wide, mostly semicircularly arched, ca. $20-50^{\circ}$ with stem axis at the basal part and incurved up to $110-170^{\circ}$ at the end; dorsal lobe insertion line arched, usually long decurrent for 1.5-2.0 of stem wide, obliquely reniform to broadly cordate, arching over the stem and farther beyond stem, slightly convex, $0.9-1.0 \times 1.2-1.4 \mathrm{~mm}, 0.55-0.75$ of ventral in size, ca. $5-25^{\circ}$ with stem axis, margin entire, apex obtuse to acute; ventral lobe insertion line arched, long decurrent for $0.5-2.0$ of stem wide, broadly ovate to rounded, flat to slightly convex, $1.6-2.4 \times 1.8-2.6 \mathrm{~mm},(1.0-1.2: 1)$, ca. $30-60^{\circ}$ with stem axis, margin entire and sometimes slightly undulate, apex rounded to broadly obtuse. Cells in the midleaf $25.0-37.5 \times 20.0-30.0 \mu \mathrm{m}$ with concave trigones; near apex 12.5-17.5 × 17.5-20.0 $\mu \mathrm{m}$, slightly thick-walled, trigones concave; at the base $45.0-62.5 \times 20.0-35.0 \mu \mathrm{m}$ with concave trigones; cuticle smooth to weakly verrucose. Oil bodies 3-9 per cells, granulate, spherical to elliptical, 4-6 $\mu \mathrm{m}$ in diameter. Specialized asexual reproduction not seen. Sexual condition dioicous. Gynoecia terminal, bracts in one pair, slightly larger than sterile leaves, dorsal lobe 1.1-1.2 $\times 1.4-1.5 \mathrm{~mm}$; ventral lobe $1.6-1.7 \times 1.8-2.0 \mathrm{~mm}$. Perianth oblong to obovate, dorsiventrally compressed, truncate, ca. $1.0 \times 1.5 \mathrm{~mm}$, mouth entire to denticulate.

Habitat: Wet rocks near streams and springs mostly in tundra zone and belt, rarely in forested areas; 40-1400 m alt.

Distribution: Sakhalin Province, Kamchatka Territory, Magadan Province, Chukotka Province.

Specimens examined: SAKHALIN PROVINCE, Sakhalin Island, Nabilskij Range, VB S-60-6-09 (VBGI), VB S-28-3a-06, S-28-106 (VBGI), VB S-30-1-06, S-30-16a-06 (VBGI), VB S-27-23-06, S-27-27b-06 (VBGI), Schmidt Peninsula VB S-50-2-09, S-50-3-09 (VBGI), Zhdanko Mt., VB S-26-6-09 (VBGI), Paramushir Island, VB K-83-4-04 (VBGI), VB K-77-9-04 (VBGI), VB K-115-5-04 (VBGI), Shumshu Island, VB K-121-36-04 (VBGI), VB K-129-2604 (VBGI), Iturup Island, VB K-48-32-05 (VBGI), VB K-52-5-05 (VBGI), VB K-16-9-17 (VBGI), Kunashir Island, VB K-37-13-06 (VBGI), Shikotan Island, VB K-49-43-07 (VBGI); KAMCHATKA TERRITORY, Commanders, Mednyj Island, VB K-23-5-04, K-2414-04 (KPABG, VBGI), Central Kamchatka, Bystrinckij Nature 
Reserve, VB K-133-1-04, K-133-8-04, K-133-31-04 (VBGI), VB K-134-3-04 (KPABG, VBGI), Eastern Kamchatka, Kronotsky State Reserve, V.Y. Neshatayeva 09.IX.1975 G106416 (VBGI), Pinachevskaya River valley, VB K-59-10-01 (KPABG, VBGI), Northern Kamchatka, Palana River basin, VB K-33-8-03 (KPABG, VBGI), Southern Kamchatka, Yuzhno-Kamchatsky Nature Reserve, V.Y. Neshatayeva 31.VIII.1985 G106447, G106450 (KPABG), Russkaya (Akhomten) Bay, VB K-74-11-04, K-74-12-04 (KPABG, VBGI).

2. Scapania uliginosa (Lindenb.) Dumort., Recueil Observ. Jungerm. 14, 1835. (Fig. 34)

Description: Plants $30.0-100.0 \times 2.5-3.5 \mathrm{~mm}$, ascending to erect, pale brownish green near apex, pale purplish red to deep reddish brown below. Stems branched at the base, pale brownish green in upper part, reddish black below, cross section $0.35-0.37 \times 0.37-0.42 \mathrm{~mm}$, cortex cells thick-walled in 1-2(-3) layers, $8.1-11.3 \times 8.1-9.7 \mu \mathrm{m}$ with reddish brown walls; inner cells larger, thin-walled, 16.2-32.3 × 16.2-24.3 $\mu \mathrm{m}$, walls colorless. Rhizoids sparse to common, colorless, isolate, spreading at right angle with stem. Leaves contiguous to imbricate; keel $0.22-0.30$ of ventral lobe length, usually lamellate-winged with wing 1-2 cells wide, slightly arched to sometimes strongly arched, ca. $25-45^{\circ}$ with stem axis at the basal part and incurved up to $120-150^{\circ}$ at the end; dorsal lobe subtransversely inserted, insertion line slightly arched, long decurrent, reniform to broadly ovate, arching over stem and beyond the stem, strongly convex $1.0-1.2 \times 0.7-1.0 \mathrm{~mm}, 0.25-0.50$ of ventral in size, ca. (-5-) $0-30^{\circ}$ with stem axis, apex rounded to obtuse; ventral lobe transversely inserted, insertion line arched for 1.5-2.0 of stem wide, long decurrent, broadly obovate, strongly convex, deflexed, $2.0-2.5 \times 2.0-2.3 \mathrm{~mm}$, (0.8-1.0 : 1), ca. $45-80^{\circ}$ with stem axis, margin denticulate, apex rounded. Cells in the midleaf rectangular, 32.4-40.5 $\times 21.1-34.3 \mu \mathrm{m}$ with concave trigones; near apex 12.0 $16.2 \times 14.2-19.5 \mu \mathrm{m}$, along margin equally thick-walled; at the base $48.6-64.8 \times 24.3-32.4 \mu \mathrm{m}$ with concave trigones; cuticle slightly verrucose. Specialized asexual reproduction by gemmae in masses at apices of shoots.

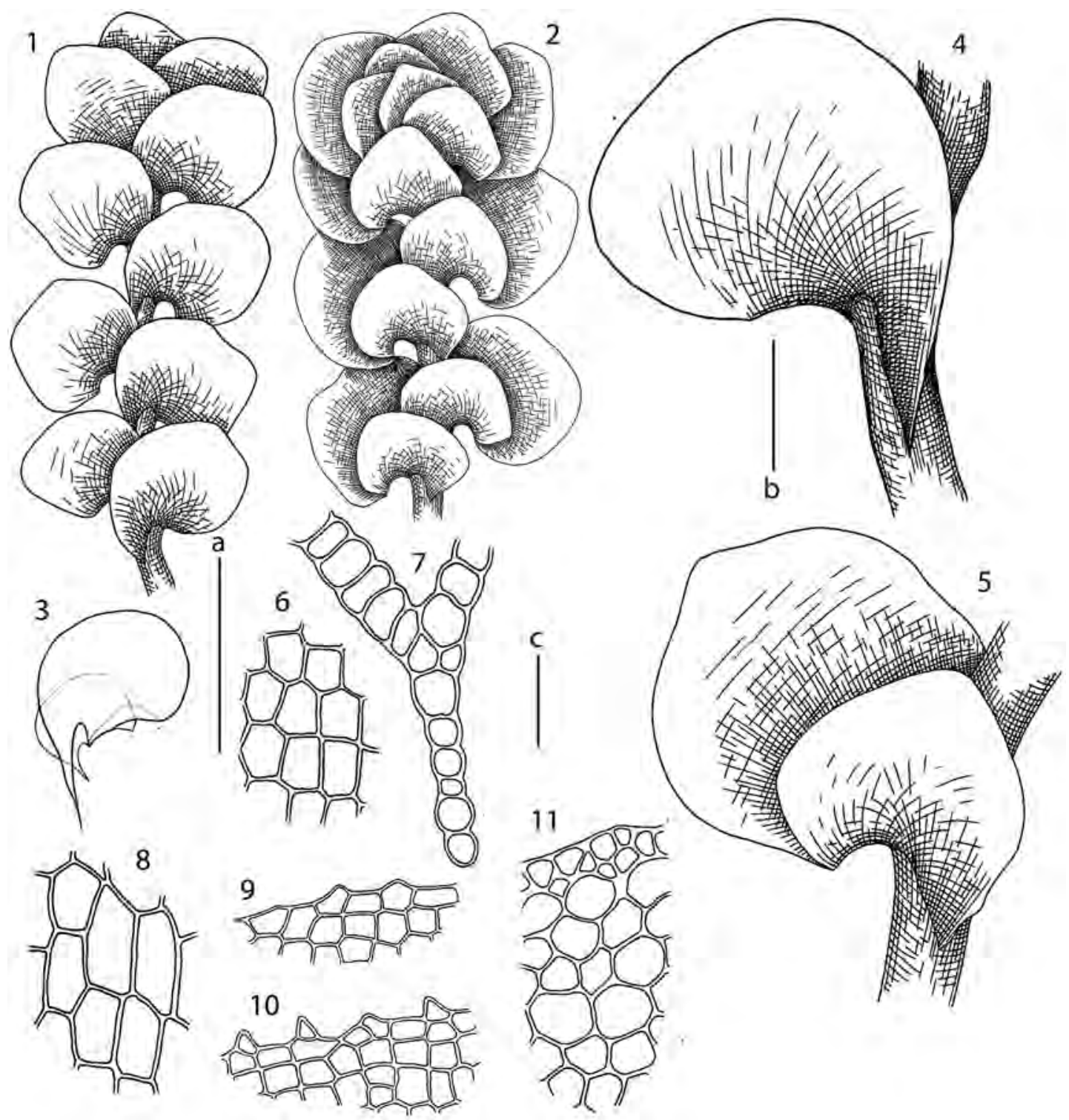

Figure 33 Scapania paludosa (Müll. Frib.) Müll. Frib. 1 - habit, ventral view; 2 - habit, dorsal view; 3 - leaf; 4 - ventral lobe insertion; 5 - dorsal lobe insertion; 6 - midleaf cells, 7 - keel cross section; 8 - leaf base cells; 9, 10 - leaf margin; 11 - stem cross section, fragment. Scales: $\mathrm{a}-2 \mathrm{~mm}$, for $1-3 ; \mathrm{b}-500 \mu \mathrm{m}$, for 4,5 ; c $-50 \mu \mathrm{m}$, for $6-11$. 


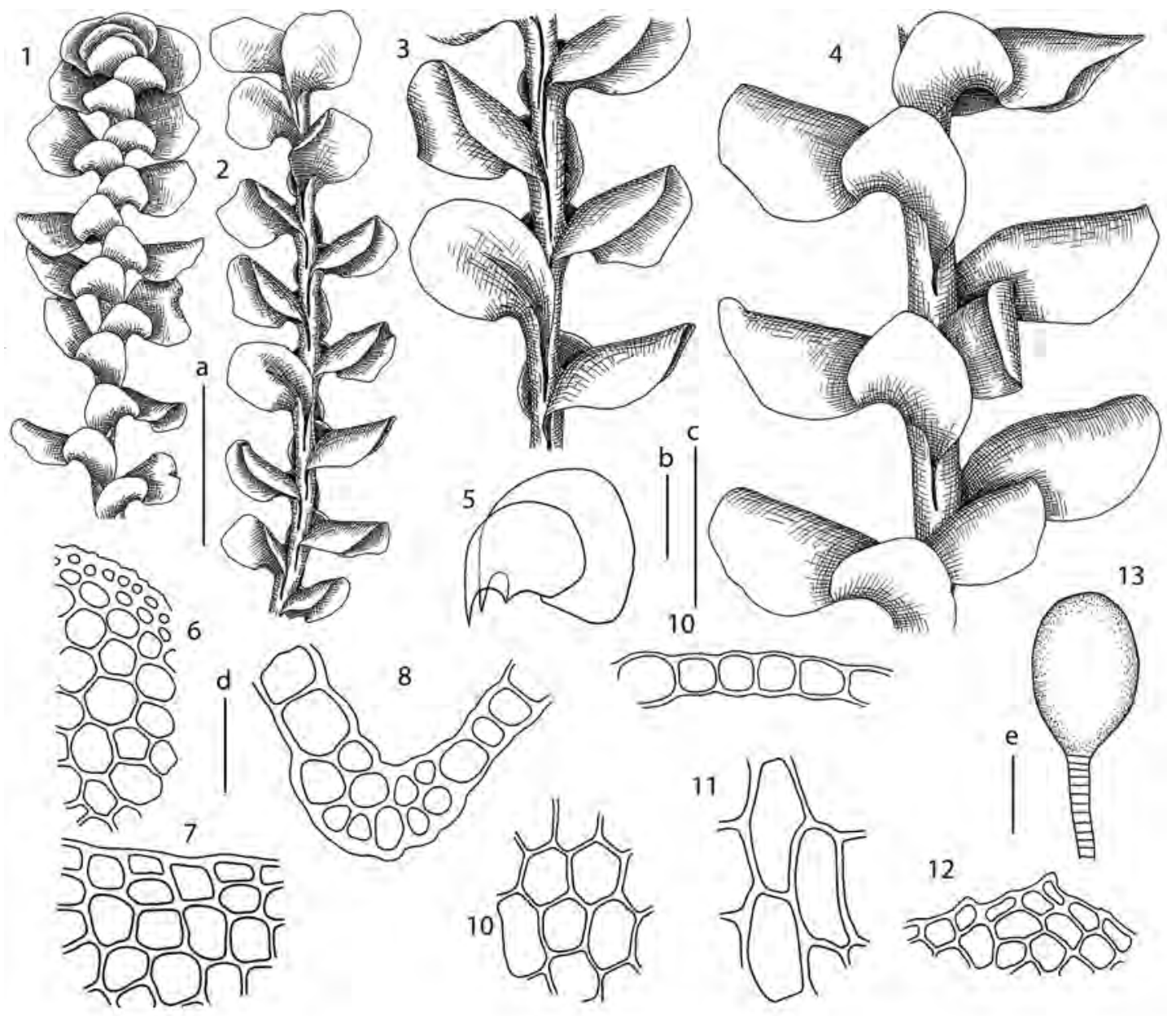

Figure 34 Scapania uliginosa (Lindenb.) Dumort. 1 - habit, dorsal view; 2 - habit, ventral view; 3 - part of shoot, ventral view; 4 - part of shoot, dorsal view; 5 - leaf; 6 - stem cross section, fragment; 7 - leaf margin; 8 - keel cross section; 9 leaf cross section, fragment; 10 - midleaf cells; 11 - leaf base cells; 12 - leaf apex; 13 - antheridium. Scales: a - $2 \mathrm{~mm}$, for 1,2 ; $\mathrm{b}-1 \mathrm{~mm}$, for 3,$5 ; \mathrm{c}-1 \mathrm{~mm}$, for 4 ; $\mathrm{d}-50 \mu \mathrm{m}$, for $6-12$, e $-100 \mu \mathrm{m}$, for 13 .

Sexual condition dioicous. Gynoecia terminal, bracts in one pair, slightly larger than sterile leaves, dorsal lobe 1.1$1.2 \times 1.0-1.2 \mathrm{~mm}$; ventral lobe $2.25-2.55 \times 2.25-2.35 \mathrm{~mm}$. Perianth oblong to obovate, dorsiventrally compressed, truncate, $3.0-3.5 \times 1.5-1.7 \mathrm{~mm}$, mouth denticulate. Seta ca. 10.0-15.0 mm long. Capsule elliptic, ca. $1200.0 \times 700.0$ $\mu \mathrm{m}$, 4-layered, inner cells $24.3-32.4 \times 16.2-24.3 \mu \mathrm{m}$, with annular thickenings, outer cells ca. 24.3-32.4 × 16.2-24.3 $\mu \mathrm{m}$ with 15-16 nodular thickenings in vertical wall. Elaters 2-spiral, ca. 100.0-150.0 × $8.1 \mu \mathrm{m}$. Spores ca. 8.1-11.3 $\mu \mathrm{m}$ in diameter, brown.

Habitat: Shaded wet rocks near streams and springs in tundra zone and belt; elevation unknown.

Distribution: Sakhalin Province, Kamchatka Territory, Chukotka Province.

[Specimens examined: MURMANSK PROVINCE, Laplandskij State Reserve, N.A. Konstantinova 10-2-01 (KPABG, VBGI, JNU).]

3. Scapania undulata (L.) Dumort., Recueil Observ. Jungerm. 14, 1835. (Fig. 35, 52: 2)

Description: Plants $10.0-50.0 \times 2.5-3.7 \mathrm{~mm}$, ascending to erect, green to reddish green in upper part, reddish black below. Stems frequently branched, green near apex, reddish black below, cross section $0.30-0.35 \times 0.40-0.50$ $\mathrm{mm}$, cortex cells thick-walled in 2-3(-4) layers, 10.0-12.5 $\times 10.0-12.5 \mu \mathrm{m}$ with reddish black walls; inner cells larger, thin-walled, $20.0-30.0 \times 17.5-25.0 \mu \mathrm{m}$, walls colorless to pale reddish. Rhizoids sparse to common, isolate, spreading at right angle with stem, colorless. Leaves imbricate; keel $0.24-0.40$ of ventral lobe length, usually $1-3$ cells wide lamellate-winged, straight to slightly arched, ca. 60-90 with stem axis at the middle part and suddenly incurved up to $110^{\circ}$ at the end; dorsal lobe transversely inserted, not decurrent, broadly ovate to rounded or rectangular, arching over stem and beyond stem, slightly convex 1.2$1.5 \times 1.0-1.2 \mathrm{~mm}, 0.3-0.6$ of ventral in size, ca. $20-50^{\circ}$ with stem axis, margin entire to denticulate, apex rounded; ventral lobe transversely inserted, insertion line arched for 1.5-2.0 of stem wide, long decurrent, obliquely obovate, $1.8-2.3 \times 1.0-1.5 \mathrm{~mm},(0.55-0.85: 1)$, ca. $50-90^{\circ}$ with stem axis, margin denticulate to dentate, apex rounded. Cells in the midleaf oblong to rectangular, 30.0-50.0 × 17.5-25.0 $\mu \mathrm{m}$ with concave trigones; near apex 12.5-17.5 $\times 17.5$ $22.5 \mu \mathrm{m}$, along margin with $2-3$ cells rows equally thickwalled; at the base $37.5-57.5 \times 25.0-30.0 \mu \mathrm{m}$ with concave trigones; cuticle slightly striolate to verrucose. Oil bodies (2-)5-8(-12) per cells, granulate, spherical to elliptical, 


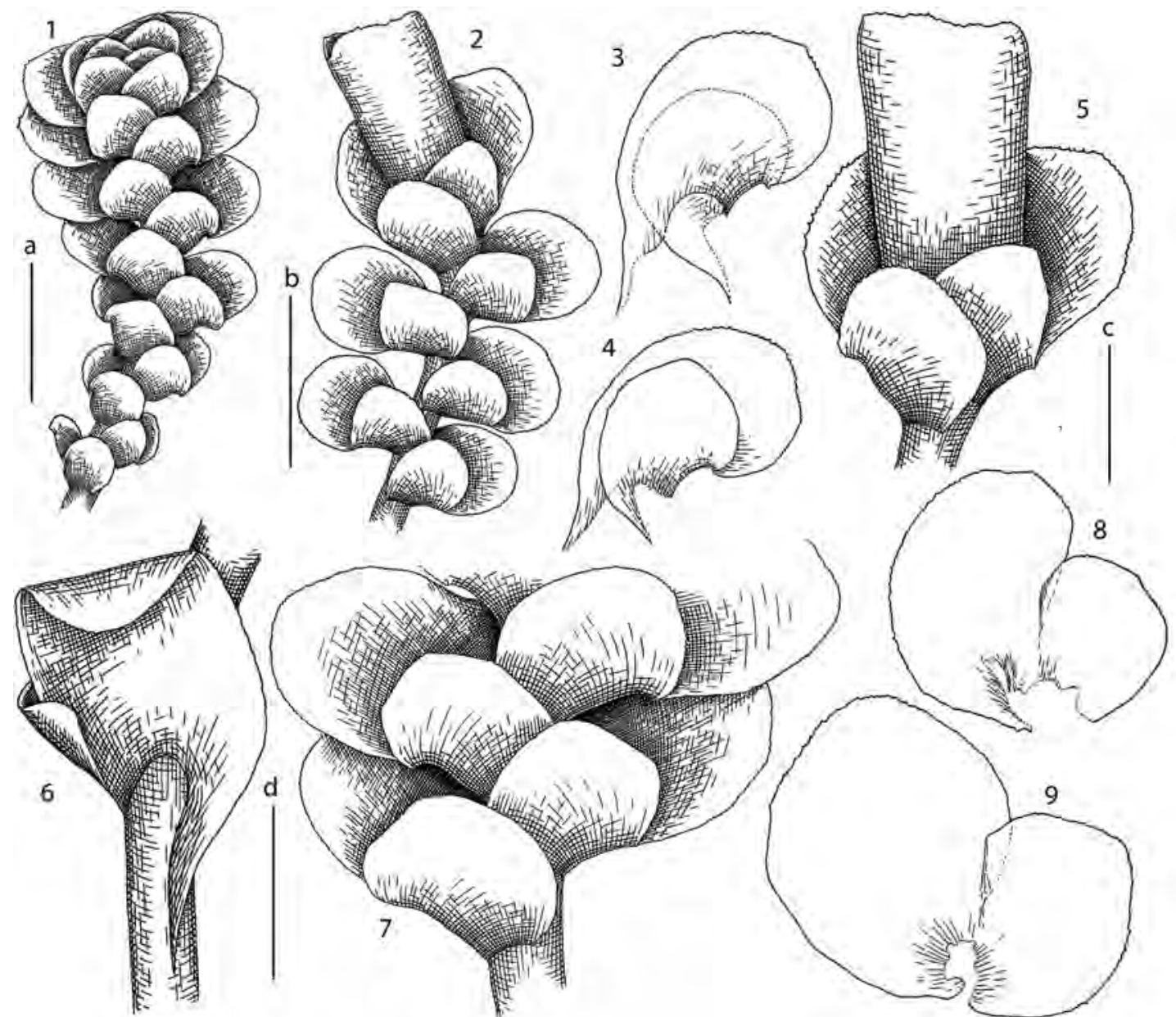

Figure 35 Scapania undulata (L.) Dumort. 1 - habit, dorsal view; 2 - perianthous plant, dorsal view; 3, 4, 8, 9 - leaves; 5 - upper part of perianthous plant; 6 - ventral lobe insertion; 7 - part of shoot, dorsal view. Scales: a $-2 \mathrm{~mm}$, for 1 ; $\mathrm{b}-2 \mathrm{~mm}$, for $2 ; \mathrm{c}-1 \mathrm{~mm}$, for 5 ; $\mathrm{d}-11 \mathrm{~mm}$, for 3, 4, 6-9.

5.0-6.0 $\mu \mathrm{m}$ in diameter, 5.0-7.0 × 6.0-9.0(-11.0) $\mu \mathrm{m}$, brown. Specialized asexual reproduction by gemmae in masses at apices of shoots, elliptical to ovate, 20.0-22.5 $\times$ 12.5-15.0 $\mu \mathrm{m}, 2$-celled, pale green. Sexual condition dioicous. Androecia intercalary, bracts in 3-5 pairs, similar to leaves but inflated in the base, 4-8 androus, body ca. $175 \times 150 \mu \mathrm{m}$, antheridial stalk 1-seriate, ca. 160.0-200.0 $\mu \mathrm{m}$ long. Gynoecia terminal, bracts in one pair, slightly larger than sterile leaves, dorsal lobe 1.50-1.75 × 1.25-1.50 $\mathrm{mm}$; ventral lobe $2.50-2.75 \times 1.50-1.75 \mathrm{~mm}$. Perianth oblong to obovate, dorsiventrally compressed, truncate, $2.8-3.0 \times 1.4-1.5 \mathrm{~mm}$, mouth entire to denticulate. Seta ca. $20.0 \mathrm{~mm}$ long. Capsule elliptic, ca. $1250.0 \times 750.0 \mu \mathrm{m}$, 6-layered, inner cells 30.0-37.5 × 20.0-30.0 $\mu \mathrm{m}$, with annular thickenings, outer cells ca. 27.5-55.0 × 25.0-37.5 with 20-21 nodular thickenings in vertical wall. Elaters 2-spiral, ca. $75.0-100.0 \times 10.0 \mu \mathrm{m}$. Spores ca. $12.0-15.0 \mu \mathrm{m}$ in diameter, brown.

Habitat: Shaded wet rocks or submerged stones along stream beds in different altitudinal belts; 20-1500 m alt.

Distribution: Primorsky Territory, Khabarovsk Territory, Sakhalin Province, Kamchatka Territory, Magadan Province, Chukotka Province.

Specimens examined: PRIMORSKY TERRITORY, Partizansky District, VB P-65-17a-06, P-65-38b-06 (VBGI), Shkotovsky Dist- rict, VB P-72-3-05 (VBGI), VB P-74-67-05 (VBGI), VB P-56-5-08 (VBGI); SAKHALIN PROVINCE, Sakhalin Island, Belaya River, M.S. Ignatov 24.VIII.2006 G22 (VBGI), Korsakovsky District, VB S-65-17-09 (VBGI), Iturup Island, VB K-24-3-07 (VBGI), VB K-52-21-05 (VBGI), VB K-65-27-05 (VBGI), Kunashir Island, VB K-37-12-06, K-37-35b-06 (VBGI), VB K-45-9a-06 (VBGI), Paramushir Island, VB K-84-4-04 (VBGI); KHABAROVSK TERRITORY, Solnechnyj District, VB Kh-6-19-07 (VBGI); KAMCHATKA TERRITORY, Commanders, Mednyj Island, VB K-56-1-04 (VBGI); MAGADAN PROVINCE, Ol'sky District, M.G. Khoreva 01.X.2004 s.n. (VBGI), Srednekansky District, VB Mag-17-14-10 (VBGI).

4. Scapania subalpina (Nees ex Lindenb.) Dumort., Recueil Observ. Jungerm. 14, 1835. (Fig. 36, 52: 5)

Description: Plants $10.0-40.0 \times 2.0-3.5 \mathrm{~mm}$, ascending to erect, yellowish green to pale green. Stems sparsely branched, yellowish green near apex and brownish green below, cross section $0.27-0.30 \times 0.30-0.35 \mathrm{~mm}$, cortex cells slightly thick-walled in 1-2 layers, $12.5-20.0 \times 12.5$ $17.5 \mu \mathrm{m}$ with reddish brown walls; inner cells larger, thinwalled, with concave trigones, $20.0-30.0 \times 20.0-25.0 \mu \mathrm{m}$, walls colorless. Rhizoids sparse to common, isolate to fasciculate, spreading at right angle with stem, colorless. Leaves imbricate; keel $0.40-0.55$ of ventral lobe length, weakly winged (wing 1-2 cells wide), usually straight to slightly arched, ca. $30-50^{\circ}$ with stem axis at the basal part and gradually incurved up to $90-100^{\circ}$ at the end; dorsal 

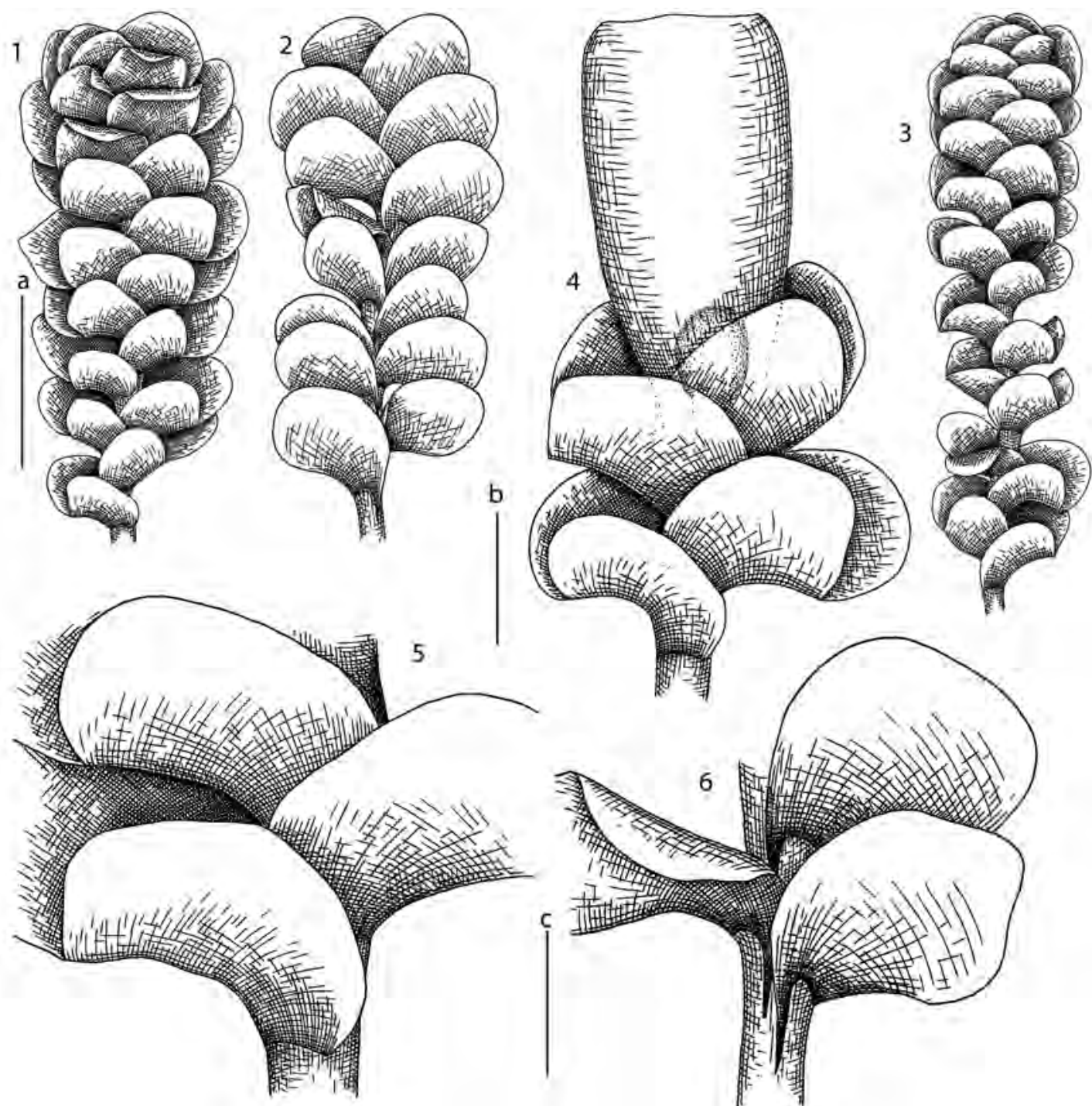

Figure 36 Scapania subalpina (Nees ex Lindenb.) Dumort. 1, 3 - habit, dorsal view; 2 - habit, ventral view; 4 - upper part of perianthous shoot; 5 - dorsal lobe insertion; 6 - ventral lobe insertion. Scales: $1-2 \mathrm{~mm}$, for $1-3 ; \mathrm{b}-1 \mathrm{~mm}$, for 4 ; c $-500 \mu \mathrm{m}$, for 5,6 .

lobe transversely inserted, insertion line slightly arched, not decurrent, obliquely ovate to subrectangular, arching over stem and farther beyond stem, flat to sometimes erect, 0.9 $1.2 \times 0.7-0.9 \mathrm{~mm}, 0.6-0.8$ of ventral in size, ca. $40-60^{\circ}$ with stem axis, margin entire, apex rounded to obtuse; ventral lobe insertion line arched, decurrent for $0.5-1.0$ of stem wide, broadly obovate, flat to slightly convex, 1.6-2.0 $\times$ $1.0-1.4 \mathrm{~mm},(0.7-0.9: 1)$, ca. $60-80^{\circ}$ with stem axis, margin denticulate and sometimes slightly undulate, apex rounded to broadly obtuse. Cells in the midleaf oblong, 22.0-37.5 $\times 20.0-35.0 \mu \mathrm{m}$ with concave trigones; near apex 15.0-28.0 $\times 10.0-24.0 \mu \mathrm{m}, 1-3$ cell rows equally thick-walled along margin, trigones concave; at the base oblong to rectangular, $(30.0-) 50.0-62.5 \times 20.0-35.0 \mu \mathrm{m}$ with concave trigones; cuticle smooth to weakly verrucose. Oil bodies 3-5(-10) per cells, spherical to elliptical, granulate, $4.0-5.6 \times 2.8-3.5$ $\mu \mathrm{m}$. Specialized asexual reproduction by gemmae in masses at apices of shoots, elliptical to ovate 17.5-22.5 $\times$ 12.5-15.0 $\mu \mathrm{m}, 2$-celled, green. Sexual condition dioicous. Gynoecia terminal, bracts in one pair, slightly larger than sterile leaves, dorsal lobe 1.6-2.0 $\times 1.0-1.2 \mathrm{~mm}$; ventral lobe $2.0-2.2 \times 1.2-1.4 \mathrm{~mm}$. Perianth oblong to obovate, dorsiventrally compressed, bend towards the ventral side at upper part, truncate, $3.2-3.4 \times 1.6-1.8 \mathrm{~mm}$, mouth entire.

Habitat: Shaded wet rocks or submerged stones along streams in different belts, becomes more common northward; 14-1500 m alt.

Distribution: Primorsky Territory, Khabarosk Territory, Sakhalin Province, Kamchatka Territory, Magadan Province, Chukotka Province.

Specimens examined: PRIMORSKY TERRITORY, Alekseevsky Range, VB P-65-6a-06, P-65-21a-06, P-65-22b-06 (VBGI); SAKHALIN PROVINCE, Sakhalin Island, Schmidt Peninsula, VB S-41-7-09, S-41-12-09 (VBGI), VB S-49-4-09 (VBGI), Iturup Island, VB K-10-12-07, K-12-13-07 (VBGI), Kunashir Island, VB K-37-14a-06, K-37-16b-06 (VBGI), VB K-39-19a-06 (VBGI), VB K-40-11-06 (VBGI), VB K-42-17-06, K-42-18-06 (VBGI), VB K-58-4-06, K-63-23-06 (VBGI), Paramushir Island, VB K-77-1a-04 (VBGI), VB K-114-2-04, K-115-8-04 (VBGI); KHABAROVSK TERRITORY, Okhotsk District, VB Kh-20-19-08 (VBGI), VB Kh-32-54-08, Kh-32-55-08, K-32-59-08 (VBGI), VB Kh-36-3-08, Kh-36-5-08 (VBGI), Solnechnyj District, VB Kh6-23-07 (VBGI); KAMCHATKA TERRITORY, Commanders, Mednyj Island, VB K-67-8-04 (KPABG, VBGI), VB K-42-5-04 (KPABG, VBGI), Central Kamchatka, Bystrinckij Nature Reserve, 

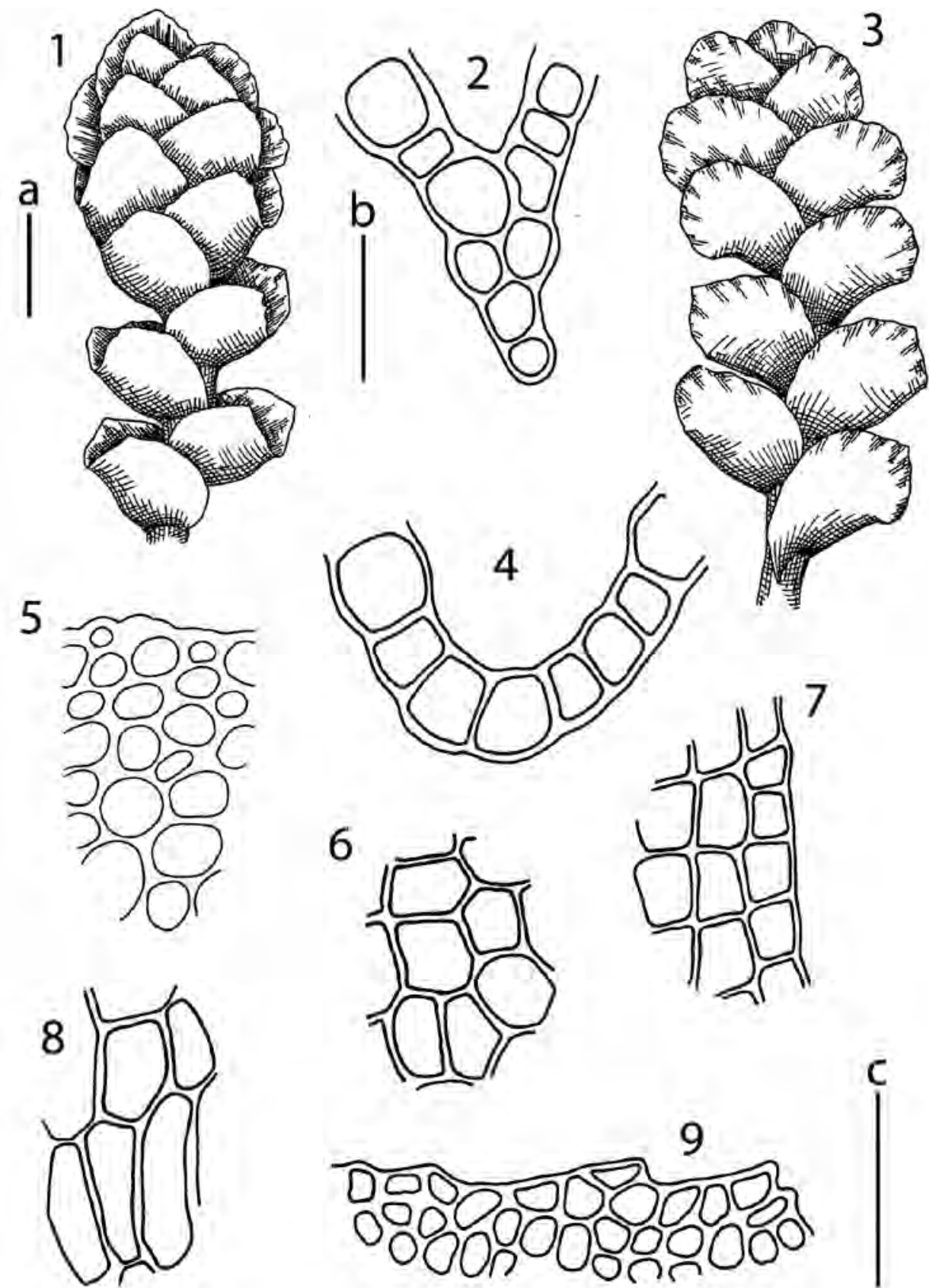

Figure 36a Scapania subalpina (Nees ex Lindenb.) Dumort. 1 - habit, dorsal view; 1 - habit, ventral view; 3, 4 - keel cross section; 5 - stem cross section, fragment; 6 - midleaf cells; 7 - leaf margin; 8 -leaf base cells; 9 - perianth mouth. Scales: $\mathrm{a}-1 \mathrm{~mm}$, for 1,$2 ; \mathrm{b}-50 \mu \mathrm{m}$, for $3-8 ; \mathrm{c}-100 \mu \mathrm{m}$, for 9 .

VB K-137-13-04 (KPABG, VBGI), Krutin'kaya River, VB K-791-03 (VBGI), Alnej Mt. area, VB K-131-1-04 (KPABG, VBGI), Uksichan River, VB K-17-5-04 (KPABG, VBGI), Eastern Kamchatka, Kronotsky State Reserve, sine coll.1977 sine n. (VBGI), Klyuchevskoy Vale, I.V. Czernyadjeva 21.VIII.2004 s. n. (VBGI); MAGADAN PROVINCE, Magadan City area, VB Mag-20-31-10, Mag-22-9-10 (VBGI).

5. Scapania obscura (Arnell et C.E.O. Jensen) Schiffn., Oesterr. Bot. Z. 58: 377, 1908. (Fig. 37)

Description: Plants $5.0-15.0 \times 0.8-1.5 \mathrm{~mm}$, prostrate to ascending, blackish. Stems sparsely branched, fuscous, cross section $0.13-0.23 \times 0.20-0.30 \mathrm{~mm}$, cortex cells thickwalled in 1(-2) layer, 11.2-14.0 × 8.4-11.2 $\mu \mathrm{m}$ with fuscous walls; inner cells larger, thin-walled, 19.6-36.4 × 16.8-22.4 $\mu \mathrm{m}$ with colorless walls. Rhizoids sparse, isolated, spreading at right angle with stem, colorless. Leaves contiguous; keel $0.55-0.70$ of ventral lobe length, straight to slightly arched, ca. $40-50^{\circ}$ with stem axis at the basal part and gradually incurved up to $80-100^{\circ}$ at the end; dorsal lobe transversely inserted, not decurrent, oblong, obliquely rectangular to obovate, $0.38-0.75 \times 0.25-0.43 \mathrm{~mm}, 0.65-0.85$ of ventral in size, ca. $20-40^{\circ}$ with stem axis, margin entire, apex rounded to obtuse, arching over- and rarely hardly beyond the stem; ventral lobe transversely inserted, line insertion arched for 0.8-1.0 wide of stem, long decurrent, obliquely oblong to obovate, slightly convex, $0.75-1.00 \times 0.37-0.55 \mathrm{~mm}$, (0.5-0.8: 1$)$, ca. $40-70^{\circ}$ with stem axis, margin entire, apex rounded to obtuse. Cells in the midleaf oblong, 28.0-36.4 $\times$ 22.4-30.8 $\mu \mathrm{m}$ with concave to triangular trigones; near apex $10.0-24.0 \times 10.0-19.6 \mu \mathrm{m}$, with triangular trigones; cells 


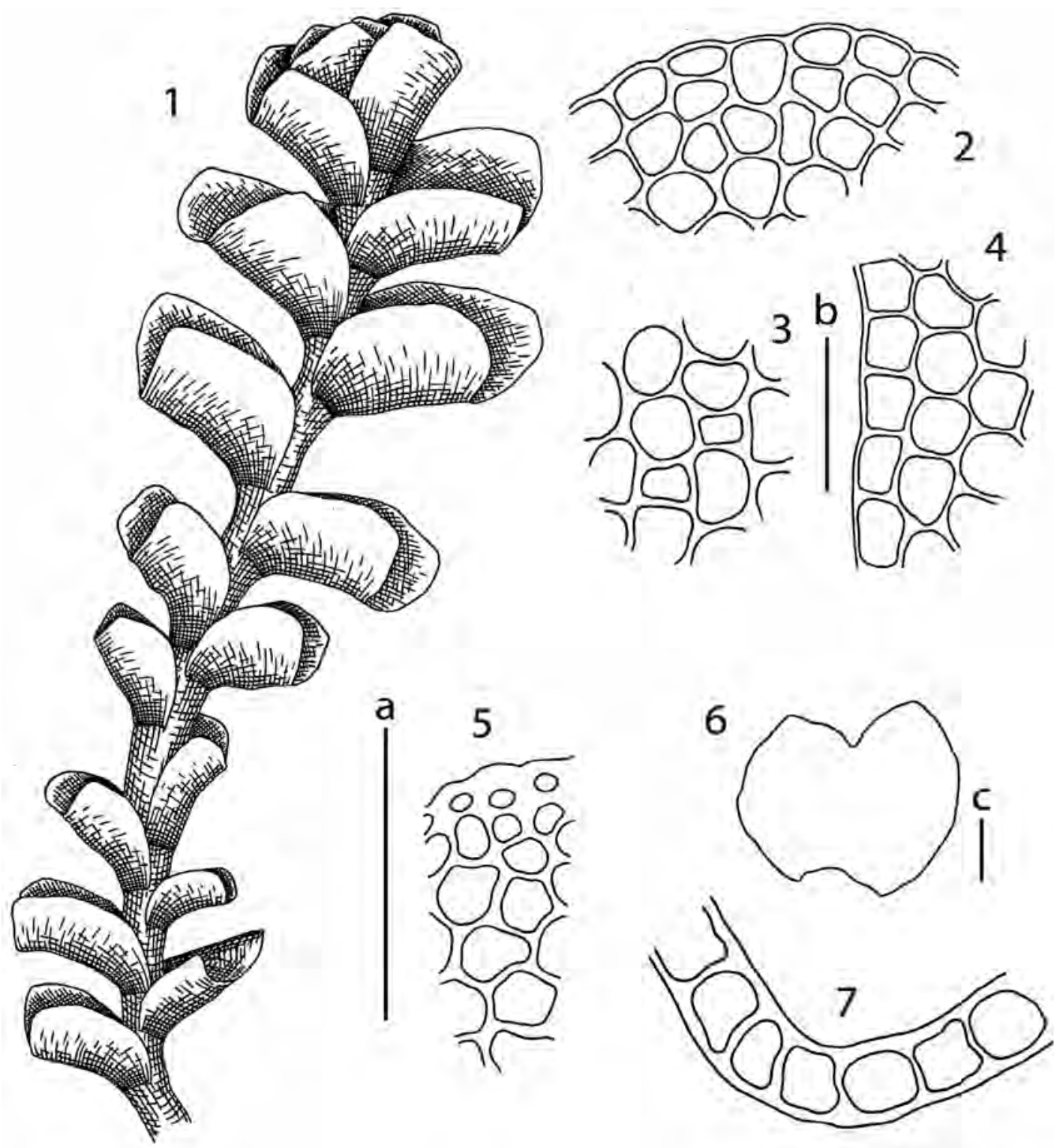

Figure 37 Scapania obscura (Arnell et C.E.O. Jensen) Schiffn. 1 - habit, dorsal view; 2 - leaf apex; 3 - midleaf cells; 4 - leaf margin; 5 - stem cross section, fragment; 6 - leaf; 7 - keel cross section. Scales: $\mathrm{a}-1 \mathrm{~mm}$, for $1 ; \mathrm{b}-50 \mu \mathrm{m}$, for $2-5,7 ; \mathrm{c}-200 \mu \mathrm{m}$, for 6 .

along margin thin-walled; at the base 23.0-36.4 × 21.0-30.8 $\mu \mathrm{m}$ with concave to triangular trigones; cuticle weakly verrucose near base. Specialized asexual reproduction by gemmae in masses at apices of shoot, broadly ovate to elliptical, 19.6-22.4 × 11.2-14.0 $\mu \mathrm{m},(1-) 2$-celled, brown. Sexual condition dioicous.

Habitat: Shaded wet rocks near streams and springs in alpine and arctic areas; 300-1400 m alt.

Distribution: Kamchatka Territory, Magadan Province.

Specimens examined: KAMCHATKA TERRITORY, Central Kamchatka, Bystrinckij Nature Reserve, VB K-137-14-04 (KPABG, VBGI), Commanders, Mednyj Island, VB K-42-3-04 (KPABG, VBGI).

6. Scapania rufidula Warnst., Hedwigia 63: 94, 1921 [1922]. (Fig. 38)

Description: Plants 30.0-50.0 × 1.8-2.0 mm, ascending to erect, green, brownish green, pale reddish brown to pale purplish. Stems sparsely branched, pale reddish brown near apex, blackish brown below, cross section 0.35-0.37 $\times 0.37-0.42 \mathrm{~mm}$, cortex cells thick-walled in 2-3(-4) layers, 8.1-16.2 × 8.1-11.3 $\mu \mathrm{m}$ with blackish brown walls; inner cells larger, thin-walled, with concave trigones, 16.2-32.4 $\times$ 16.2-24.3 $\mu \mathrm{m}$, walls colorless to pale brownish. Rhizoids numerous in dense fascicles spreading at right angle with stem, colorless. Leaves contiguous to imbricate; keel 0.350.45 of ventral lobe length, straight to suddenly slightly arched, usually 3-6 cells lamellate-winged, ca. $20-60^{\circ}$ with stem axis at the middle part and up to $90^{\circ}$ at the end, ciliate to dentate, teeth 1-6 cells long, 1-2 cells wide; dorsal lobe subtransversely inserted, insertion line straight to slightly arched, slightly decurrent, obliquely reniform to broadly ovate, arching over stem and beyond stem, slightly convex, $0.75-1.00 \times 1.00-1.25 \mathrm{~mm}, 0.4-0.6$ of ventral in size, ca. $(-10-) 0-20^{\circ}$ with stem axis, margin dentate, teeth $1-2(-3)$ cells long, one cell wide, apex rounded to obtuse; ventral lobe transversely inserted, insertion line arched for 1.0-1.2 of stem wide, long decurrent, broadly obovate, slightly to 

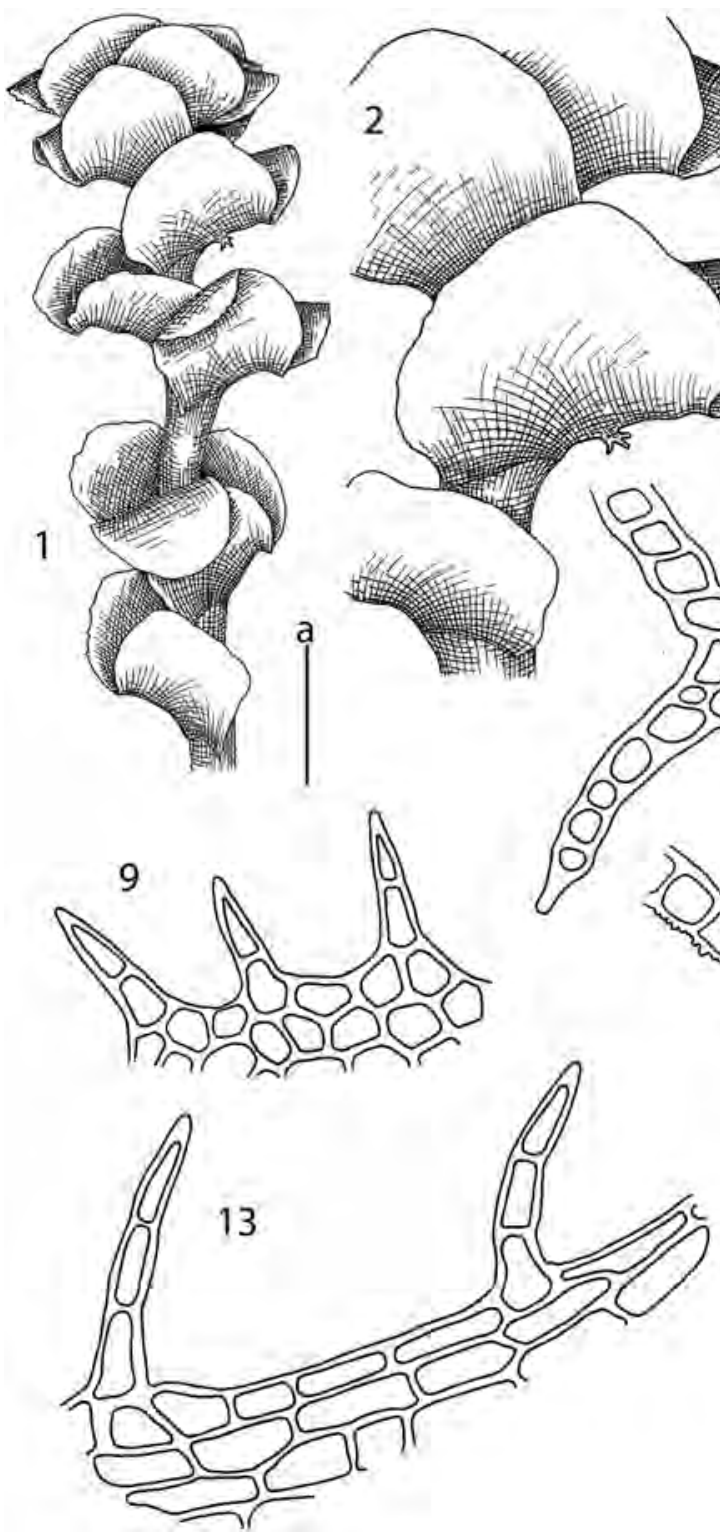
(1)

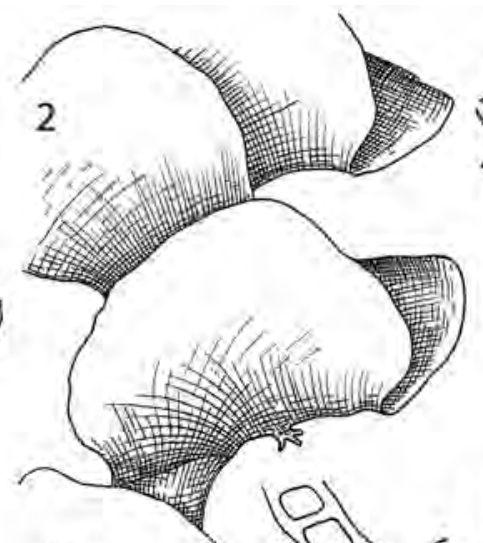

3

3 多, 6
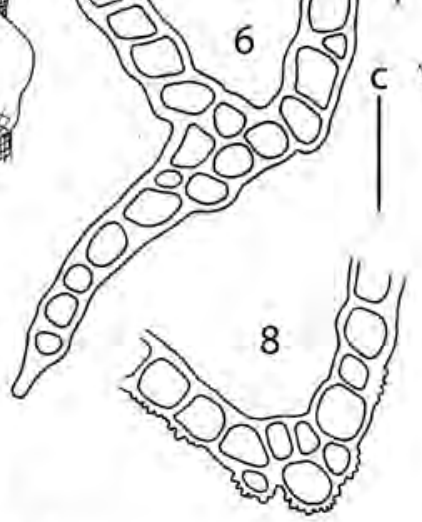

12

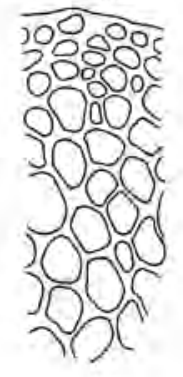

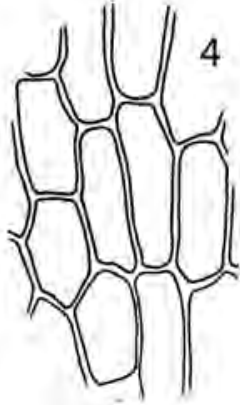
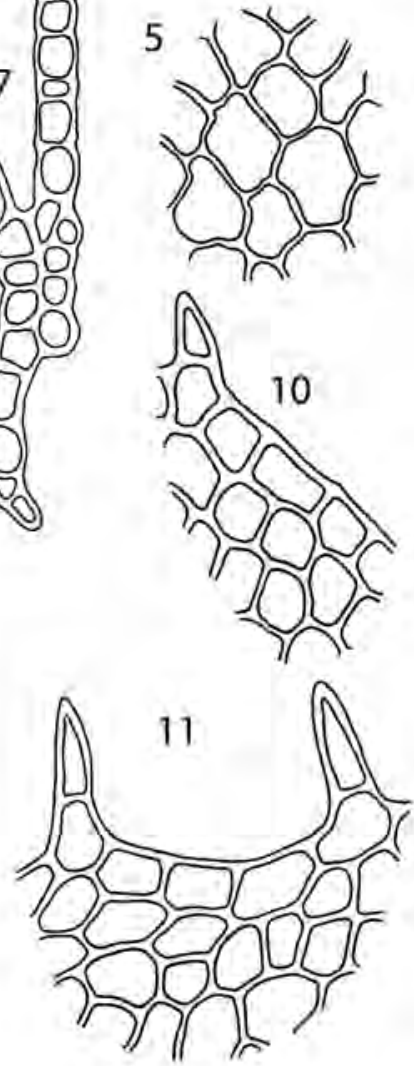

Figure 38 Scapania rufidula Warnst. 1 - habit, dorsal view; 2 - part of shoot, dorsal view; 3 - ventral lobe insertion; 4 - leaf base cells; 5 - midleaf cells; 6-8 - keel cross section; 9-11 - leaf margin; 12 - stem cross section, fragment; 13 - keel teeth. Scales: $\mathrm{a}-1 \mathrm{~mm}$, for $1 ; \mathrm{b}-500 \mu \mathrm{m}$, for 2,3 ; c $-50 \mu \mathrm{m}$, for $4-13$.

strongly recurved, $1.50-2.00 \times 1.25-1.50 \mathrm{~mm},(0.75-0.85$ : 1), ca $10-40^{\circ}$ with stem axis, margin ciliate, cilia $1-7$ cells long, 1(-2) cells wide, apex rounded to obtuse. Cells in the midleaf rectangular, $24.3-42.4 \times 16.2-34.3 \mu \mathrm{m}$ with concave trigones; near apex 12.0-19.5 × 16.2-24.3 $\mu \mathrm{m}$, along margin with $2-3(-4)$ cell rows equally thick-walled; at the base rectangular, 48.6-64.8 $\times 16.2-34.3 \mu \mathrm{m}$ with concave trigones; cuticle distinctly striolate. Oil bodies 4-6 per cells, granulate, spherical to elliptical, 5.6-8.4 × 4.0-5.6 $\mu \mathrm{m}$. Specialized asexual reproduction by gemmae in masses at apices of shoots, elliptical to ovate, 24.3-32.4 $\times$ 13.0-16.2 $\mu \mathrm{m}, 2$-celled, green. Sexual condition dioicous. Androecial bracts in 3-5 pairs, similar to leaves, but slightly inflated in the base, 3-5 androus, body ca. $200.0 \times 170.0$ $\mu \mathrm{m}$, antheridial stalk 1-seriate, ca. $130.0 \mu \mathrm{m}$ long.

Habitat: Shaded wet rocks along stream beds; mostly in tundra altitudinal belt and zone; 399-1900 m alt.

Distribution: Primorsky Territory, Khabarosk Territory, Magadan Province, Chukotka Province.
Specimens examined: KHABAROVSK TERRITORY, Dusse-Alin Range, D.A. Petelin 24.VIII.1987 sine n. (MHA, VBGI); MAGADAN PROVINCE, Tenkinsky District, N. Sinelnikova 10.VIII.2007 37y (VBGI); CHUKOTKA PROVINCE, Anadyrskij District, O.M. Afonina 10.VII.1981 109042k (KPABG), PRIMORSKY TERRITORY, Alekseevsky Range, S.S. Choi R5028, R5043, R5044 (JNU, VBGI).

7. Scapania spitsbergensis (Lindb.) Müll. Frib., Bull. Herb. Boissier, sér. 2, 1: 607, 1901. (Fig. 39).

Plants $20.0-50.0 \times 2.5-3.5 \mathrm{~mm}$, ascending to erect, green, brownish green to pale reddish brown. Stems sparsely branched, reddish brown near apex, blackish brown below, cross section $0.25-0.38 \times 0.38-0.50 \mathrm{~mm}$, cortex cells thickwalled in 1-2 layers, 13.0-15.6 × 7.8-10.4 $\mu \mathrm{m}$ with blackish brown walls; inner cells larger, thin-walled, 13.0-26.0 $\times$ 13.0-26.0 $\mu \mathrm{m}$, walls colorless to pale brownish. Rhizoids sparse, colorless, isolate, spreading at right angle with stem. Leaves contiguous to imbricate; keel $0.10-0.35$ of ventral lobe length, semicircularly arched, usually lamellate-winged, with wing $5-7$ cells wide, ca. $20-25^{\circ}$ with stem axis at the 


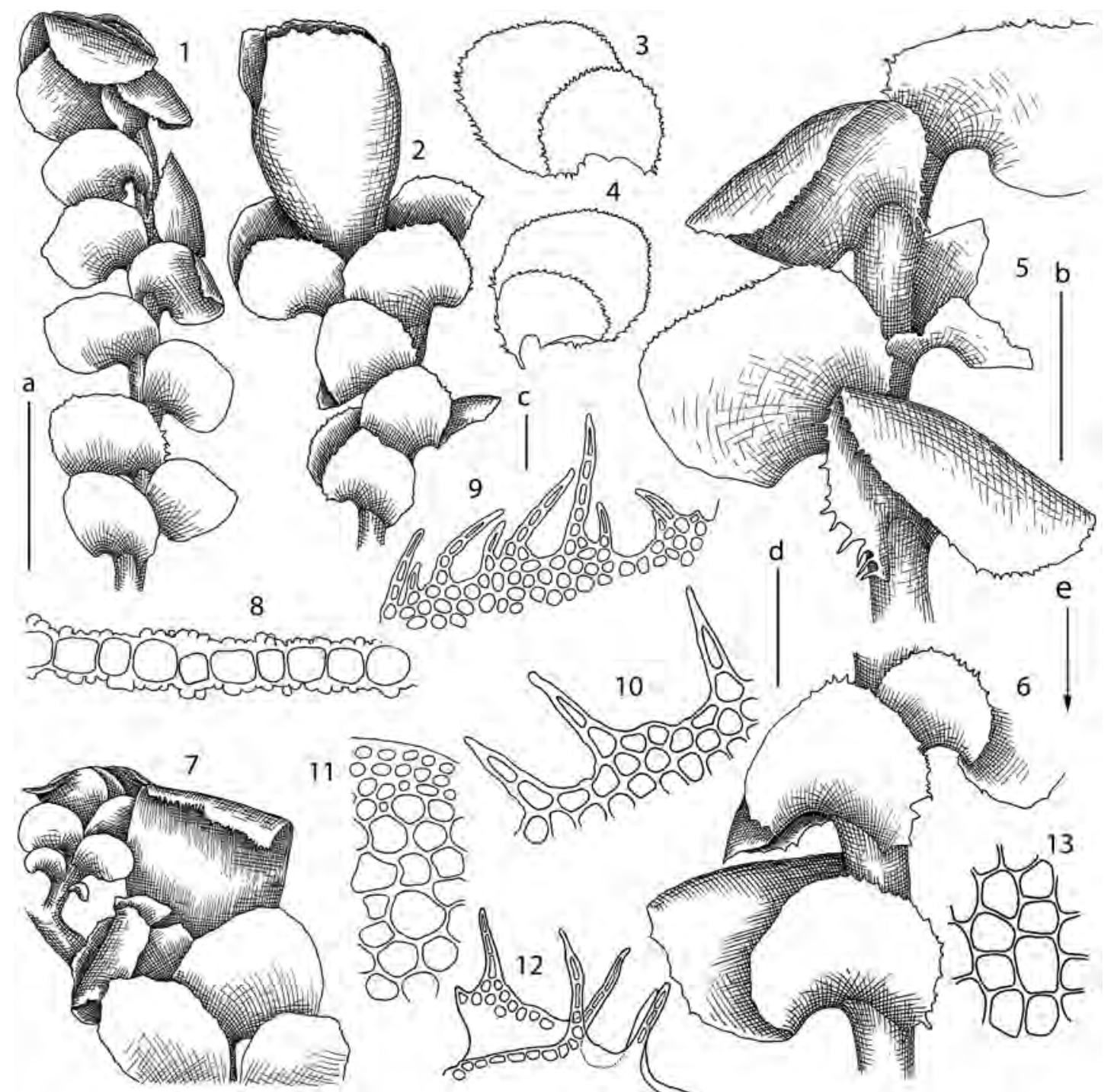

Figure 39 Scapania spitsbergensis (Lindb.) Müll. Frib. 1 - habit, ventral view; 2 - perianthous plant, dorsal view; 3, 4-leaves; 5 ventral lobe insertion; 6 - dorsal lobe insertion; 7 - upper part of perianthous plant; 8 - leaf cross section, fragment; 9 - leaf margin near ventral base; 10 - leaf margin; 11 - stemm cross section, fragment; 12 - perianth mouth armature, fragment; 13 - midleaf cells. Scales: $\mathrm{a}-2 \mathrm{~mm}$, for 1,$2 ; \mathrm{b}-1 \mathrm{~mm}$, for $5-7 ; \mathrm{c}-500 \mu \mathrm{m}$, for 3,$4 ; \mathrm{d}-100 \mu \mathrm{m}$, for $9 ; \mathrm{e}-50 \mu \mathrm{m}$, for $8,10-13$.

middle part and incurved up to $120-180^{\circ}$ at the end; dorsal lobe subtransversely inserted, insertion line slightly arched, shortly decurrent, reniform to broadly obovate, arching over stem and beyond stem, strongly convex, $0.75-1.00 \times 1.00$ $1.50 \mathrm{~mm}, 0.5-0.6$ of ventral in size, ca. $5-30^{\circ}$ with stem axis, margin denticulate to ciliate, teeth $1-5$ cells long, 1-3 cells wide, apex rounded to obtuse; ventral lobe transversely inserted, insertion line arched for 1.0-1.5 of stem wide, long decurrent, orbicular to broadly obovate, strongly recurved, $1.75-22.50 \times 1.50-1.75 \mathrm{~mm},(0.8-1.0: 1)$, ca. $30-50^{\circ}$ with stem axis, margin ciliate, $1-5$ cells long, 1-3 cells wide, apex rounded to obtuse. Cells in the midleaf polygonal, 24.3-32.4 × 16.2-24.3 $\mu \mathrm{m}$, with triangular trigones; near apex $8.1-11.3 \times 16.2-21.1 \mu \mathrm{m}$, along margin with $2-3$ cell rows equally thick-walled; at the base $48.6-56.7 \times 16.2-27.5$ $\mu \mathrm{m}$, with convex trigones; cuticle verrucose. Specialized asexual reproduction by gemmae in masses at apices of shoots, elliptical, 25.0-32.0 × 11.2-18.0 $\mu \mathrm{m}, 2$-celled, green. Sexual condition paroicous. Androecia below of perianth, bracts in 3-4 pairs, similar to leaves but slightly inflated in the base, 1-4 androus, body ca. $160 \times 100 \mu \mathrm{m}$, antheridial stalk 1-seriate, ca. 160-300 $\mu \mathrm{m}$ long. Gynoecia terminal, bracts in one pair (commonly include antheridia), slightly larger than sterile leaves, dorsal lobe 1.50-1.75 $\times$ $1.50-1.75 \mathrm{~mm}$; ventral lobe $1.70-1.85 \times 1.70-1.85 \mathrm{~mm}$. Perianth oblong to obovate, weakly plicate, dorsiventrally compressed, truncate, in the upper part bend towards the ventral side, $2.00-2.50 \times 1.50-1.75 \mathrm{~mm}$, mouth ciliate to lobulate, with lobulae 1-6 cells long, 1-3 cells wide.

Habitat: Shaded rocks in stony fields or crevices in gravelly barrens field in tundra belt; $500 \mathrm{~m}$ alt.

Distribution: Magadan Province, Chukotka Province.

Specimens examined: MAGADAN PROVICE, Srednekansky District, VB Mag-14-6-10 (VBGI).

SCAPANLA SECT. NEMOROS AE H. Buch, Soc. Sci. Fennica, Comm. Biol. 3(1): 152, 1928

Scapania sect. Nemorosae Müll. Frib., Rabenh. Krypt.-Fl., 2 Ahfl. 6(1): 155. 1905. nom. nud.

Description: Plants ca. $10.0-100.0 \times 2.0-5.5 \mathrm{~mm}$, ascending to erect, in dense patches, green to brownish green. Stems sparsely branched, yellowish pale brown near apex, 
deep brown below, cortex cells thick-walled in (1-)2-4 layers. Rhizoids sparse, isolate, spreading at right angle with stem, colorless. Leaves imbricate; keel $0.4-0.5$ of ventral lobe length, straight to slightly arched; dorsal lobe transversely inserted, not decurrent to decurrent, roundedoblong to rectangular, usually convex; ventral lobe insertion line arched, decurrent for 1.5-2.0 of stem width, broadly oblong-obovate, 0.7-0.8: 1, margin entire near base and distantly denticulate to dentate near apex, teeth 1-3 cells long, 1-2 cell wide at the base, apex obtuse to subacute. Cells in the midleaf polygonal, with concave to convex trigones; near apex thick-walled or thin-walled along margin, with convex trigones; at the base with convex trigones; cuticle striolate to weakly verrucose. Oil bodies 2-6 per cell, shortly ovate, finely granulate to papillose. Specialized asexual reproduction by gemmae in masses at apices of shoots, 1-celled, brown, 16.8-19.6 × 11.2-14.0 $\mu \mathrm{m}$. Sexual condition dioicous. Gynoecia terminal, bracts in one pair, slightly larger than sterile leaves. Perianth oblong to obovate, truncate, dorsiventrally compressed, the upper part bend towards the ventral side, mouth entire to remotely denticulate.

Species ca. 3 (1 in the flora): Eurasia, North America.

Comments: The section includes three species, one of them $(S$. crassiretis) is confirmed in the Russian Far East in the course of the present study, and another one (S. ampliata) was mistakenly recorded in Bakalin (2010). The latter record was based on misidentification of $S$. parvidens. Nevertheless we suppose the species highly probably will be found in the southern flank of studied area.

\section{Key to species of Scapania sect. Nemorosae}

1. Dorsal lobe decurrent; trigones concave to triangular; margin of ventral lobe dentate
1. Dorsal lobe not decurrent; trigones bulging; margin of ventral lobe denticulate 1. S. crassiretis.

2. Dorsal lobe usually convex, cordate to rounded-quadrangular .... ... [S. nemorea $]$.

2. Dorsal lobe flat, obliquely erect, ovate to triangular-cordate ........ [S. ampliata, Fig. 40].

1. Scapania crassiretis Bryhn, Rev. Bryol. 19: 7, 1892. (Fig. 41, 52: 24)

Description: Plants ca. $10.0-25.0 \times 2.0-3.5 \mathrm{~mm}$, ascending to erect, in dense patches, green to brownish green. Stems sparsely branched, yellowish pale brown near apex, deep brown below, cross section $0.25-0.30 \times 0.35-0.40 \mathrm{~mm}$, cortex cells thick-walled in 1-2(-3) layers, $11.2-16.8 \times 8.4-11.2 \mu \mathrm{m}$ with brown walls; inner cells larger, thin-walled with concave trigones, 19.6-28.0 × 8.4-11.2 $\mu \mathrm{m}$ with colorless walls. Rhizoids sparse, isolated, spreading at right angle with stem, colorless. Leaves imbricate; keel $0.4-0.5$ of ventral lobe length, straight to slightly incurved, usually strongly lamellate-winged with wing $2-8$ cells wide, ca. $60-80^{\circ}$ with stem axis at the basal part and gradually incurved up to $90^{\circ}$ at the end; dorsal lobe transversely inserted, not decurrent, oblong-rounded to rectangular, usually convex, $1.0-1.4 \times 0.7-0.8 \mathrm{~mm}, 0.5-0.6$ of ventral in size, ca. $30-50^{\circ}$ with stem axis in the middle part of stem, margin entire; apex obtuse to acute; ventral lobe insertion line arched, decurrent for $1.5-2.0$ of stem width, broadly oblong-obovate, 1.7-2.0 $\times 1.2$ $1.5 \mathrm{~mm}(0.7-0.8: 1)$, ca. $60-70^{\circ}$ with stem axis, margin entire near base and remotely denticulate to dentate near apex, teeth 1-2 cells long, one cell wide, apex obtuse to subacute. Cells in the midleaf polygonal, $24.0-33.6 \times 22.4-30.0 \mu \mathrm{m}$ with convex trigones; near apex 14.0-22.0 $\times 14.0-21.0 \mu \mathrm{m}$, thin-walled with convex trigones; at the base $42.0-56.0 \times 22.4-28.0 \mu \mathrm{m}$ with convex trigones; cuticle striolate to weakly verrucose. Oil bo-
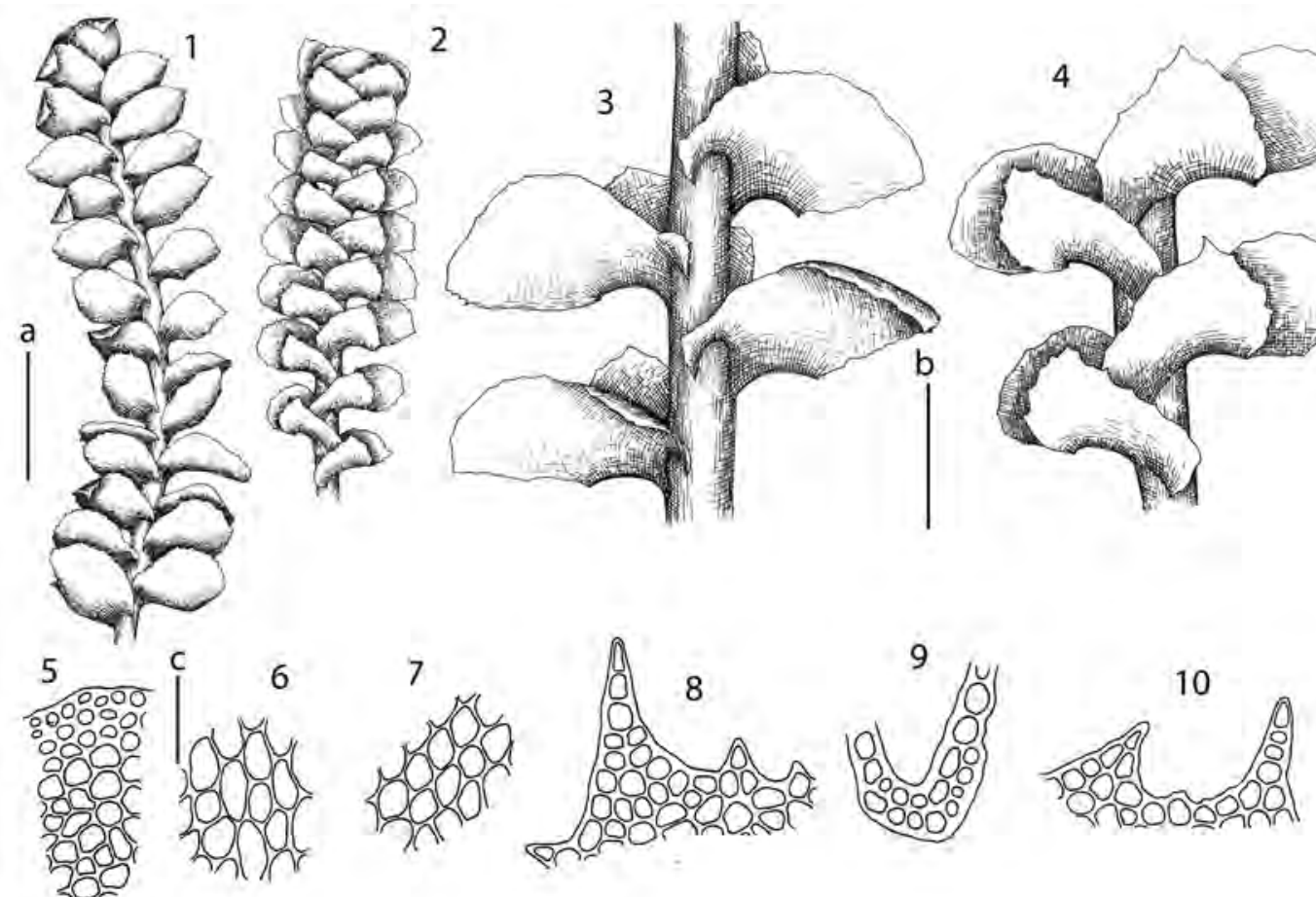

Figure 40 Scapania ampliata Steph. 1 - habit, ventral view; 2 - habit, dorsal view; 3 - part of shoot, ventral view; 4 - part of shoot, dorsal view; 5 - stem cross section, fragment; 6 - ventral lobe basal cells; 7 - ventral lobe middle cells; 8 leaf apex; 9 - keel cross section; 10 - leaf margin. Scales: a - $1 \mathrm{~mm}$, for 1, 2; b - 0.5 mm, for 3, 4; c - 50 $\mu \mathrm{m}$, for 5-10. 

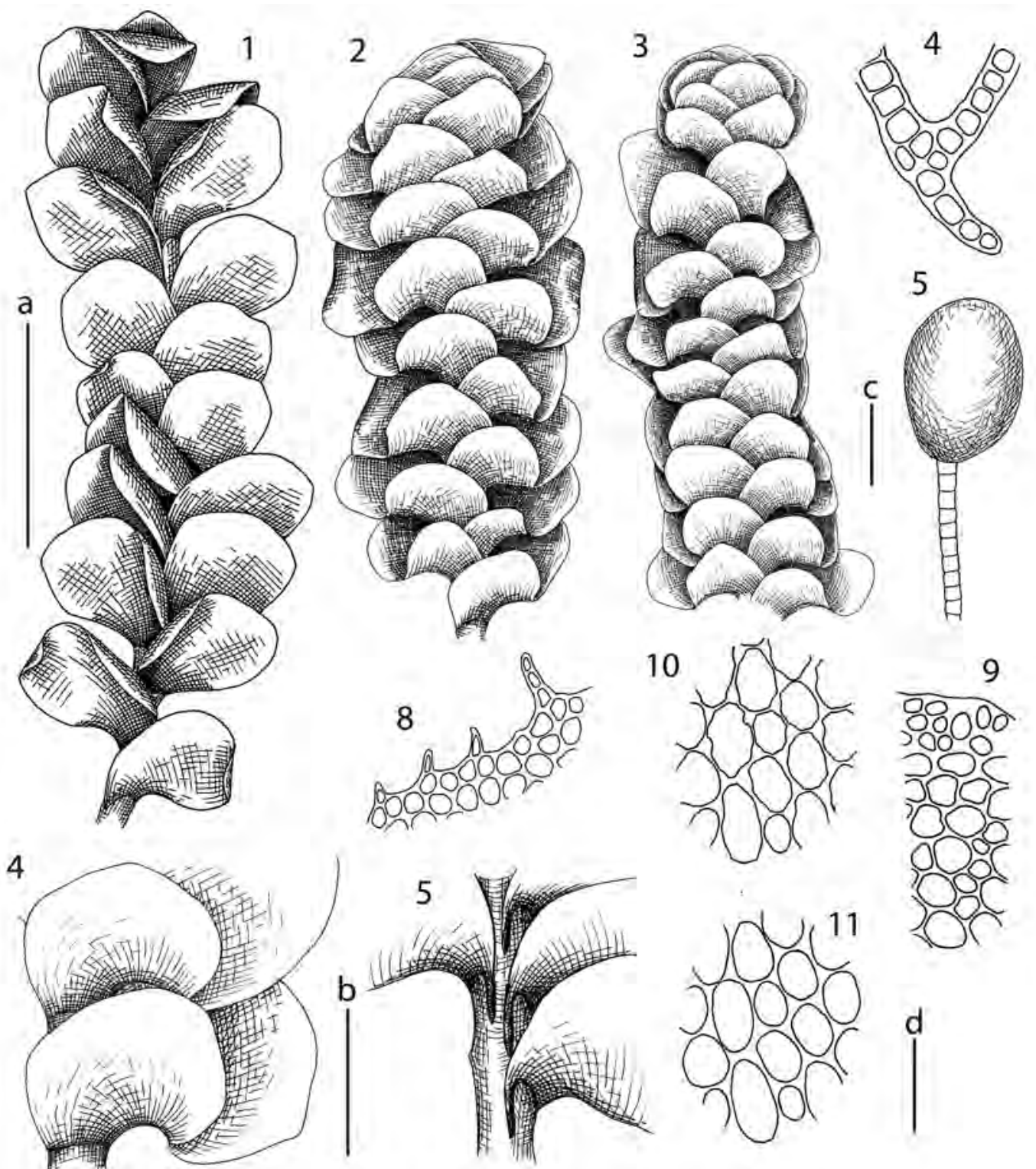

Figure 41 Scapania crassiretis Bryhn 1 - habit, ventral view; 2, 3 - habit, dorsal view; 4 - part of shoot, dorsal view; 5 part of shoot, ventral view, 6 - keel cross section; 7 - antheridium; 8 - leaf margin; 9 - stem cross section, fragment; 10,11 - midleaf cells. Scales: $\mathrm{a}-2 \mathrm{~mm}$, for $1-3 ; \mathrm{b}-1 \mathrm{~mm}$, for 4,$5 ; \mathrm{c}-100 \mu \mathrm{m}$, for $6-9 ; \mathrm{d}-50 \mu \mathrm{m}$, for 10,11 .

dies 4-6 per cell, shortly ovate, $8.0-11.0 \times 7.0-9.0 \mu \mathrm{m}$, finely granular to papillose. Specialized asexual reproduction by gemmae in masses at apices of shoots, 1-celled, brown, 16.8$19.6 \times 11.2-14.0 \mu \mathrm{m}$. Sexual condition dioicous. Gynoecia terminal, bracts in one pair, slightly larger than sterile leaves, dorsal lobe 1.4-1.6 × 1.0-1.2 mm; ventral lobe 1.8-2.0 $\times$ $1.2-1.5 \mathrm{~mm}$. Perianth oblong to obovate, $2.0-2.2 \times 1.4-1.6$ $\mathrm{mm}$, truncate, dorsiventrally compressed, the upper part bend toward the ventral side, mouth entire to remotely denticulate.

Habitat: Shaded wet rocks near streams; crevices in stony field; dark coniferous forest belt in southern flank of the area and mostly tundra belt northward; 699-1800 m alt.

Distribution: Primorsky Territory, Sakhalin Province, Magadan Province, Chukotka Province.

Specimens examined: PRIMORSKYTERRITORY, Alekseevsky Range, VB P-65-9-06, P-65-10-06, P-65-33a-06, P-65-35-06, P-6536b-06 (VBGI), VB P-56-20-08 (VBGI), Shkotovsky District, VB P-74-69-05, P-74-78-05, P-74-83-05 (VBGI); SAKHALIN PROVINCE, Sakhalin Island, Skalistaya River, VB S-27-19-06,
S-27-21-06 (VBGI), Nabilskij Range, VB S-61-27-09, S-61-28-09, S-61-32-09 (VBGI); KHABAROVSK TERRITORY, Dusse-Alin Range, B.I. Borisov 25.VII.1992 160 (MHA, VBGI).

SCAPANLA SECT. AEQUILOBAE Müll. Frib., Rabenh. Krypt.-Fl. 6(2): 472, 1915.

Scapania sect. Aequlobae Müll. Frib., Nova Acta Acad. Carol.-Ces. 83: 219, 1905. nom. nud.

Scapania sect. Spheriferae Konstant. \& Potemkin, Ann. Bot. Fennici 31: 125, 1994. syn. nov.

Scapania sect. Verrucosae Potemkin, J. Hattori Bot. Lab. 85: 54, 1998. syn. nov.

Description: Plants 10.0-20.0 × 2.0-3.6 mm, ascending to erect, green to brownish green. Stems sparsely branched, yellowish to reddish brown near apex, brownish black below, cross section $0.25-0.30 \times 0.18-0.20 \mathrm{~mm}$, cortex cells thickwalled in $1-3$ layers, $10.0-12.5 \times 7.5-10.0 \mu \mathrm{m}$ with brown walls; inner cells larger, thin-walled, $12.5-20 \times 12.5-20 \mu \mathrm{m}$ with colorless walls. Rhizoids sparse to common, colorless. Leaves 
contiguous to imbricate; keel $0.3-0.5$ of ventral lobe length, usually lamellate-winged with wing 1-3 cells wide, straight to slightly arched, ca. $30-45^{\circ}$ with stem axis at the middle part and up to $60-80^{\circ}$ at the end; dorsal lobe transversely inserted, insertion line arched, not decurrent, obliquely ovate to rectangular, $1.0-1.2 \times 0.5-0.7 \mathrm{~mm}, 0.5-0.7$ of ventral in size, ca. $30-45^{\circ}$ with stem axis, margin dentate, apex obtuse to acute; ventral lobe transversely inserted, insertion line arched, decurrent for $1-1.5$ of stem width, obliquely oblong to obovate, $1.2-1.5 \times 0.7-1.0 \mathrm{~mm},(0.6-0.7: 1)$, ca. $30-50^{\circ}$ with stem axis, margin dentate, apex rounded to obtuse and acute. Cells in the midleaf polygonal, with triangular to convex trigones; near apex with concave trigones; at the base with convex trigones; cuticle strongly coarsely papillose. Specialized asexual reproduction by gemmae scattered or in masses at apices of leaves, elliptical, spherical or angular, 1-4(-8)-celled, green to brown. Sexual condition dioicous. Gynoecia terminal, bracts in one pair, slightly larger than sterile leaves. Perianth oblong to obovate, dorsiventrally compressed to weakly plicate, truncate, mouth lobulate to ciliate with cilia 1-3 cells long.
Species ca. 6 (3[4] in the flora): Eurasia, North America (Table 6).

Key to the species of Scapania sect. Aequilobae in the Russian Far East

1. Dorsal lobe decurrent .................................................................... 2

2. Dorsal and ventral lobes strongly deflexed; trigones strongly bulging; ventral lobe denticulate; strictly Arctic, calciphilous ..........

2. Dorsal and ventral lobes slightly convex; trigones triangular; ventral lobe with dense linear cilia; southernmost flank of treated area, South Temperate, acidophilous .................................. 2. S. ciliata.

1. Dorsal lobe not decurrent .....

.... 3.

3. Gemmae 4-8-celled, spherical to (rarely) angular; marginal cells thin-walled . 3. S. sphaerifera.

3. Gemmae 2-celled, elliptical to angular; marginal cells equally thick-walled .................................................................... [4. S. verrucosa].

1. Scapania simmonsii Bryhn \& Kaal. Bryhn, Rep. 2-nd Norwegian Arctic Exped. "Fram" 1898-1902 2(11): 51, 1906. (Fig. 42)

Description: Plants $60.0-80.0 \times 2.3-3.5 \mathrm{~mm}$, ascending to erect, pale brownish green, brownish green to blackish

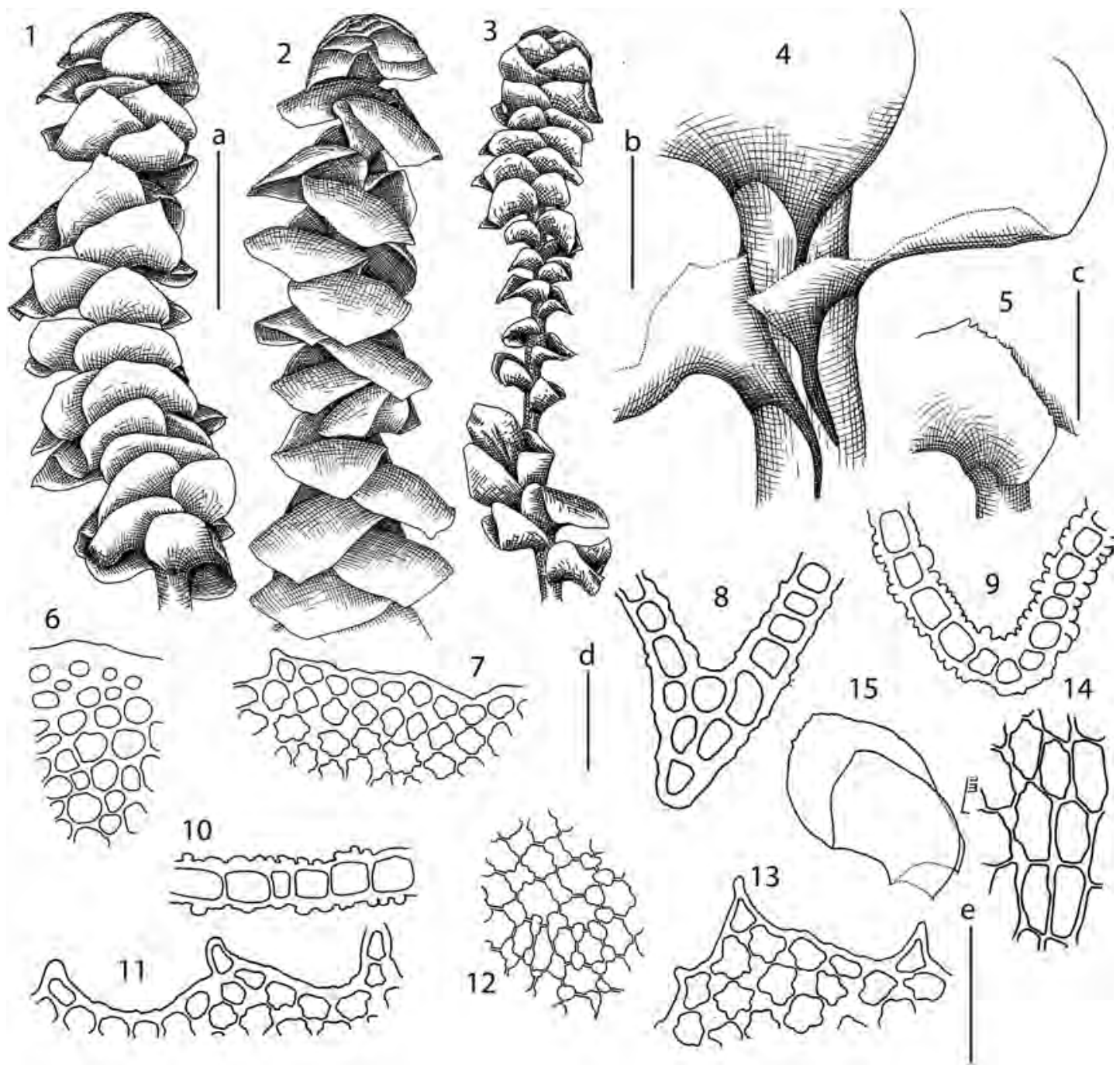

Figure 42 Scapania simmonsii Bryhn \& Kaal. 1 - habit, dorsal view; 2 - habit, ventral view; 3 - perianthous plant, dorsal view; 4 - ventral lobe insertion; 5 - dorsal lobe insertion; 6 - stem cross section, fragment; 7 - leaf margin; 8,9 - keel cross section; 10 - leaf cross section, fragment; 11,13 - perianth mouth armature, fragment; 12 - midleaf cells; 14 - lobe base cells; 15 - leaf. Scales: $\mathrm{a}-2 \mathrm{~mm}$, for $1-3$; b - $100 \mu \mathrm{m}$, for 4 ; c $-1 \mathrm{~mm}$, for 5 ; d - $50 \mu \mathrm{m}$, for $6-14$; e -2 $\mathrm{mm}$, for 15 . 
Table 6. Comparison of Species of Scapania Sect. Aequlobae

\begin{tabular}{|l|c|c|c|c|}
\hline Characters & S. sphaerifera & S. simmonsii & S. ciliata & {$[S$. verrucosa $]$} \\
\hline Ventral lobe margin & dentate & denticulate to dentate & linear ciliate & denticulate \\
\hline Trigones in the midleaf & triangular & bulging & concave & convex \\
\hline Ventral lobe & slightly convex & strongly convex, involute & slightly convex & convex \\
\hline Decurrency of dorsal lobe & not decurrent & decurrent & decurrent & not decurrent \\
\hline Marginal cells of ventral lobe & thin-walled & $\begin{array}{c}\text { thin-walled with bulging } \\
\text { trigones }\end{array}$ & equally thick-walled & equally thick-walled \\
\hline Gemmae & $(2-) 4-8$-celled, brown & not seen & $\begin{array}{c}\text { 2-celled, green, reddish } \\
\text { to brownish }\end{array}$ & $\begin{array}{c}\text { 2-celled, yellowish green } \\
\text { to brownish }\end{array}$ \\
\hline
\end{tabular}

brown. Stems sparsely branched, pale brownish green near apex, blackish brown below, cross section $0.20-0.25$ $\times 0.30-0.37 \mathrm{~mm}$, cortex cells thick-walled in 3-4 layers, 13.0-16.2 $\times 8.1-13.0 \mu \mathrm{m}$ with blackish brown walls; inner cells larger, thin-walled, $13.0-32.4 \times 13.0-24.3 \mu \mathrm{m}$ with colorless to pale brown walls. Rhizoids sparse, isolated, spreading at right angle with stem, colorless. Leaves closely imbricate; keel $0.35-0.45$ of ventral lobe length, straight to slightly arched, ca. $45-90^{\circ}$ with stem axis at the middle part and gradually incurved up to $110-120^{\circ}$ at the end; dorsal lobe transversely inserted, insertion line slightly arched, long decurrent, reniform to obliquely ovate, arching over stem and beyond stem, convex, 1.62-1.87 × 0.75-1.20 $\mathrm{mm}, 0.7-0.9$ of ventral in size, ca. $15-50^{\circ}$ with stem axis, margin entire to denticulate, apex rounded to obtuse; ventral lobe transversely inserted, insertion line arched for 1.2-1.5 of stem width, long decurrent, obliquely obovate to subrounded, strongly recurved, convex, 2.12-2.25 × 1.5.0 $1.75 \mathrm{~mm},(0.75-0.85: 1)$, ca. $80-90^{\circ}$ with stem axis, margin denticulate to dentate, apex rounded. Cells in the midleaf polygonal, 15.3-29.1 $\times 14.0-24.3 \mu \mathrm{m}$, with bulging trigones; near apex 8.1-15.0 $\times 9.2-24.3 \mu \mathrm{m}$, with bulging trigones; at the base 32.4-48.6 $\times 16.2-24.3 \mu \mathrm{m}$ with bulging trigones; cuticle coarsely verrucose. Oil bodies $3-4(-7)$ per cells, spherical to elliptical, 5.6-8.4 ×5.0-6.0 $\mu \mathrm{m}$, granulate. Specialized asexual reproduction not seen. Sexual condition dioicous. Androecia intercalary, bracts in 4-6 pairs, similar to leaves, but inflated in the base. Gynoecia terminal, bracts in one pair, slightly larger than sterile leaves, dorsal lobe $2.25-2.50 \times 1.50-1.75 \mathrm{~mm}$; ventral lobe $2.50-2.75$ $\times 1.50-1.75 \mathrm{~mm}$. Perianth oblong to obovate, weakly plicate, truncate, $3.5-4.0 \times 2.0-2.5 \mathrm{~mm}$, mouth lobulate to ciliate, lobulae 3-6 cells long, 1-3 cells wide at base.

Habitat: Humus over calcareous rocks in tundra belt; $150 \mathrm{~m}$ alt.

Distribution: Magadan Province, Chukotka Province.

Comments: The perianth is very valuable for understanding of relationship within sect. Aequilobae, since being weakly plicate in shape and ciliate to lobulate at the mouth it shows intermediate position between $S$. sphaerifera, an representative of sect. Aequilobae s. str., and $S$. verrucosa which was recently transferred to oligotypic sect. Verrucosae (Potemkin, 1998).

Specimens examined: MAGADAN PROVINCE, Omsukchanskij District, M.G. Khoreva 03.VII.2004 sine n. (VBGI), Mt. Zamkovaya, S.S. Choi and VB 31.VII.2011 R5813, R5824 (JNU).

2. Scapania ciliata Sande Lac., Ann. Mus. Bot. Lugduno-Batavi 3: 209, 1867. (Fig. 43, 44)
Description: Plants 10.0-35.0 $\times 3.2-3.6 \mathrm{~mm}$, ascending to erect, yellowish brown to brownish green. Stems sparsely branched, yellowish brown near apex, blackish brown below, cross section $0.20-0.25 \times 0.25-0.32 \mathrm{~mm}$, cortex cells thickwalled in 3-4 layers, $12.5-20.0 \times 10.0-12.5 \mu \mathrm{m}$ with brown walls; inner cells larger, thin-walled, 17.5-25.0 × 12.5-17.5 $\mu \mathrm{m}$ with colorless to pale brown walls. Rhizoids common to numerous, fasciculate, spreading at right angle with stem, colorless. Leaves contiguous to imbricate; keel 0.20-0.35 of ventral lobe length, not winged, usually straight to slightly arched, ca. $30-50^{\circ}$ with stem axis at the basal part and gradually incurved up to $90-120^{\circ}$ at the end; dorsal lobe transversely inserted, insertion line arched, slightly decurrent for $0.3-0.5$ of stem wide, obliquely rectangular to ovate, arching over stem and farther beyond stem, 1.0-1.2 $\times 0.7-0.9 \mathrm{~mm}, 0.5-0.6$ of ventral in size, ca. $40-50^{\circ}$ with stem axis, margin densely ciliate, cilia usually 1 -celled, linear, 50.0-150.0 $\mu \mathrm{m}$ long, apex rounded to obtuse; ventral lobe transversely inserted, insertion line arched, decurrent for 1.0-1.5 of stem width, obliquely elliptical to obovate, convex, $1.6-2.0 \times 1.0-1.3 \mathrm{~mm},(0.6-0.8: 1)$, ca. $60-70^{\circ}$ with stem axis, margin densely ciliate, apex rounded to obtuse. Cells in the midleaf $17.5-35.0 \times 12.5-25.0 \mu \mathrm{m}$ with concave trigones; near apex rectangular, 7.5-12.5 $\times$ $7.5-12.5 \mu \mathrm{m}$, with concave trigones; at the base $30.0-37.5$ $\times 17.5-22.5 \mu \mathrm{m}$ with triangular trigones; cuticle strongly coarsely verrucose. Specialized asexual reproduction by 2 -celled, $17.5-22.5 \times 10.0-12.5 \mu \mathrm{m}$, green, reddish to brownish elliptical gemmae. Sexual condition dioicous. Gynoecia terminal, bracts in one pair, slightly larger than sterile leaves, dorsal lobe $1.2-1.3 \times 0.8-0.9 \mathrm{~mm}$; ventral lobe 1.8-2.0 × 1.3-1.4 mm. Perianth oblong to obovate, dorsiventrally compressed, truncate, ca. 2.0-2.6 × 1.6-1.8 $\mathrm{mm}$, mouth lobulate, with linear cilia $1-3$ cells long.

Habitat: Over humus on rocks and decaying wood in coniferous with admixture broad-leaved trees Temperate forest; $400 \mathrm{~m}$ alt.

Distribution: Primorsky Territory.

Specimens examined: PRIMORSKY TERRITORY, Khasansky District, VB P-3-3-07, P-3-7-07, P-3-27-07 (VBGI).

3. Scapania sphaerifera $\mathrm{H}$. Buch, Memoranda Soc. Fauna Fl. Fenn. 11: 228, 1936. (Fig. 45, 46, 52: 6)

Description: Plants 10.0-20.0 × 2.0-2.5 mm, ascending to erect, green to brownish green. Stems sparsely branched, reddish brown near apex, brownish black below, cross section $0.25-0.30 \times 0.18-0.20 \mathrm{~mm}$, cortex cells thick-walled 

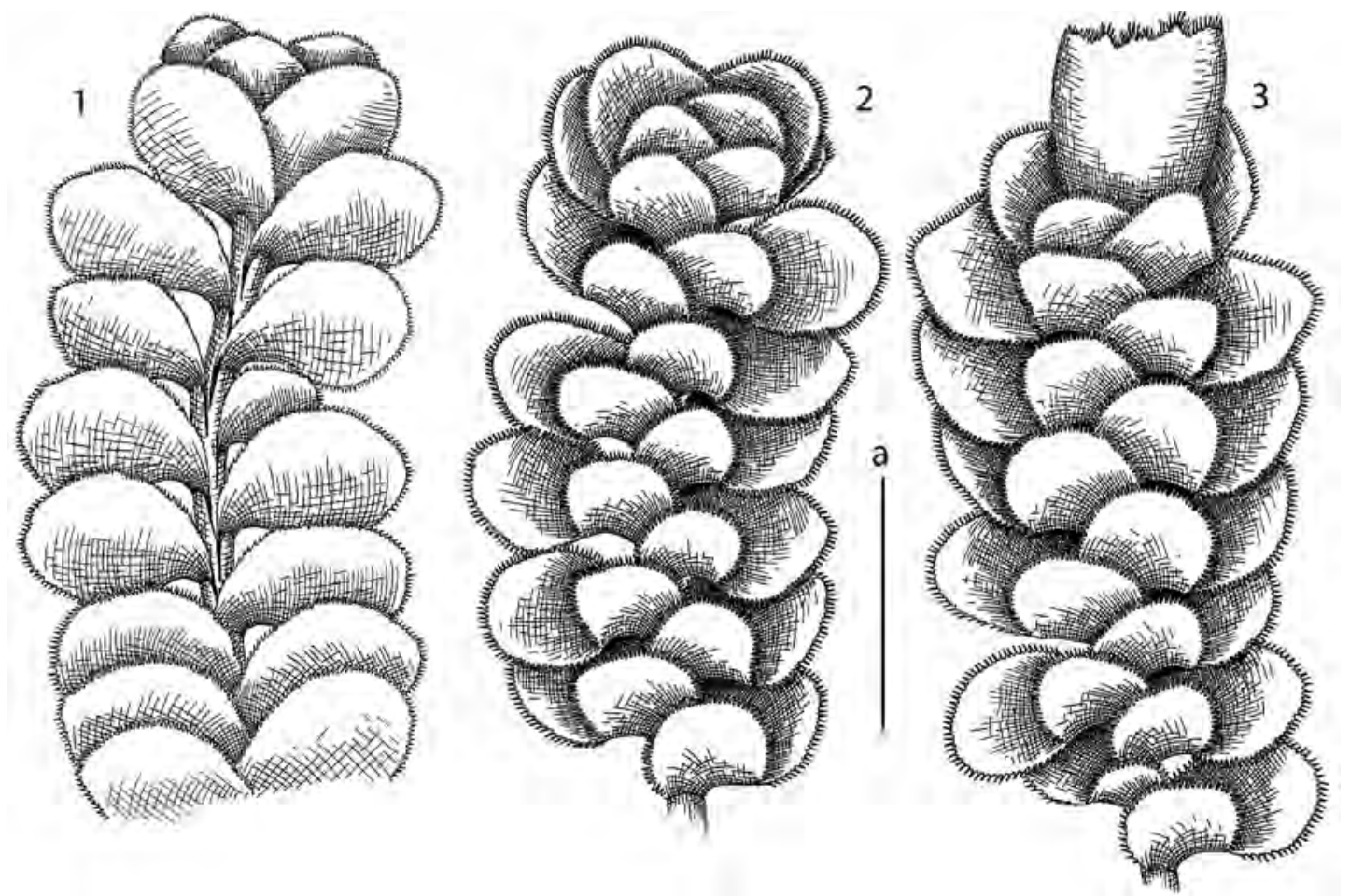

Figure 43 Scapania ciliata Sande Lac. 1 - habit, ventral view; 2 - habit, dorsal view; 3 - perianthous plant, dorsal view. Scale: a $-2 \mathrm{~mm}$, for $1-3$

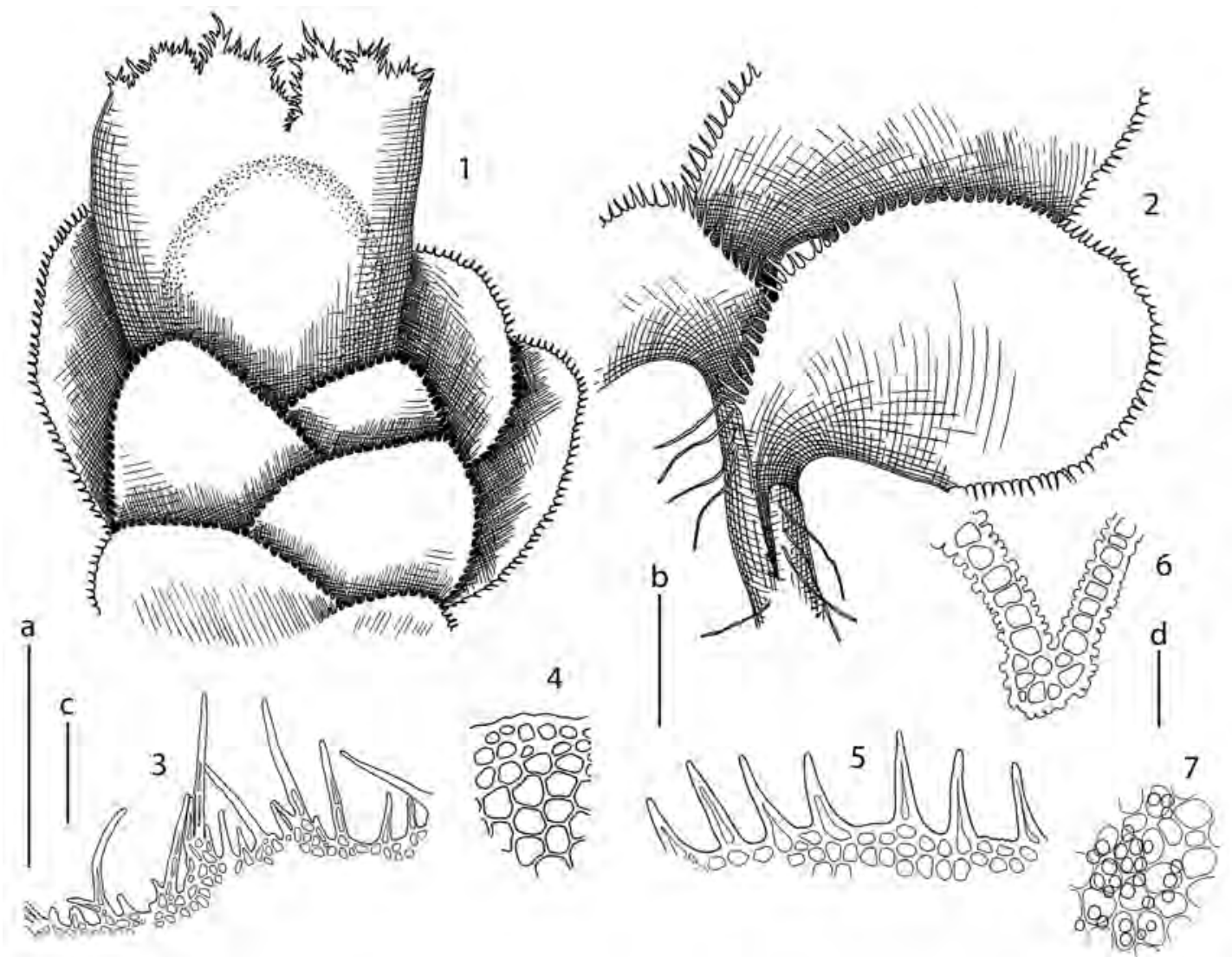

Figure 44 Scapania ciliata Sande Lac. 1 - upper part of perianthous shoot, dorsal view; 2 - part of shoot, ventral view; 3 - perianth mouth armature; 4 - stem cross section, fragment; 5 - leaf margin; 6 - keel cross section; 7 - midleaf cells (showing papillae). Scales: $\mathrm{a}-1 \mathrm{~mm}$, for $1 ; \mathrm{b}-500 \mu \mathrm{m}$, for $2 ; \mathrm{c}-200 \mu \mathrm{m}$, for $3 ; \mathrm{d}-50 \mu \mathrm{m}$, for $4-7$.

in 2-3 layers, $10.0-12.5 \times 7.5-10.0 \mu \mathrm{m}$ with brown walls; inner cells larger, thin-walled, $12.5-20.0 \times 12.5-20.0 \mu \mathrm{m}$ with colorless walls. Rhizoids sparse to common, colorless. Leaves contiguous to imbricate; keel $0.3-0.5$ of ventral lobe length, usually lamellate-winged with wing 1-3 cells wide, straight to slightly arched, ca. $30-45^{\circ}$ with stem axis at the middle part and up to $60-80^{\circ}$ at the end; dorsal lobe transversely inserted, insertion line arched, not decurrent, 


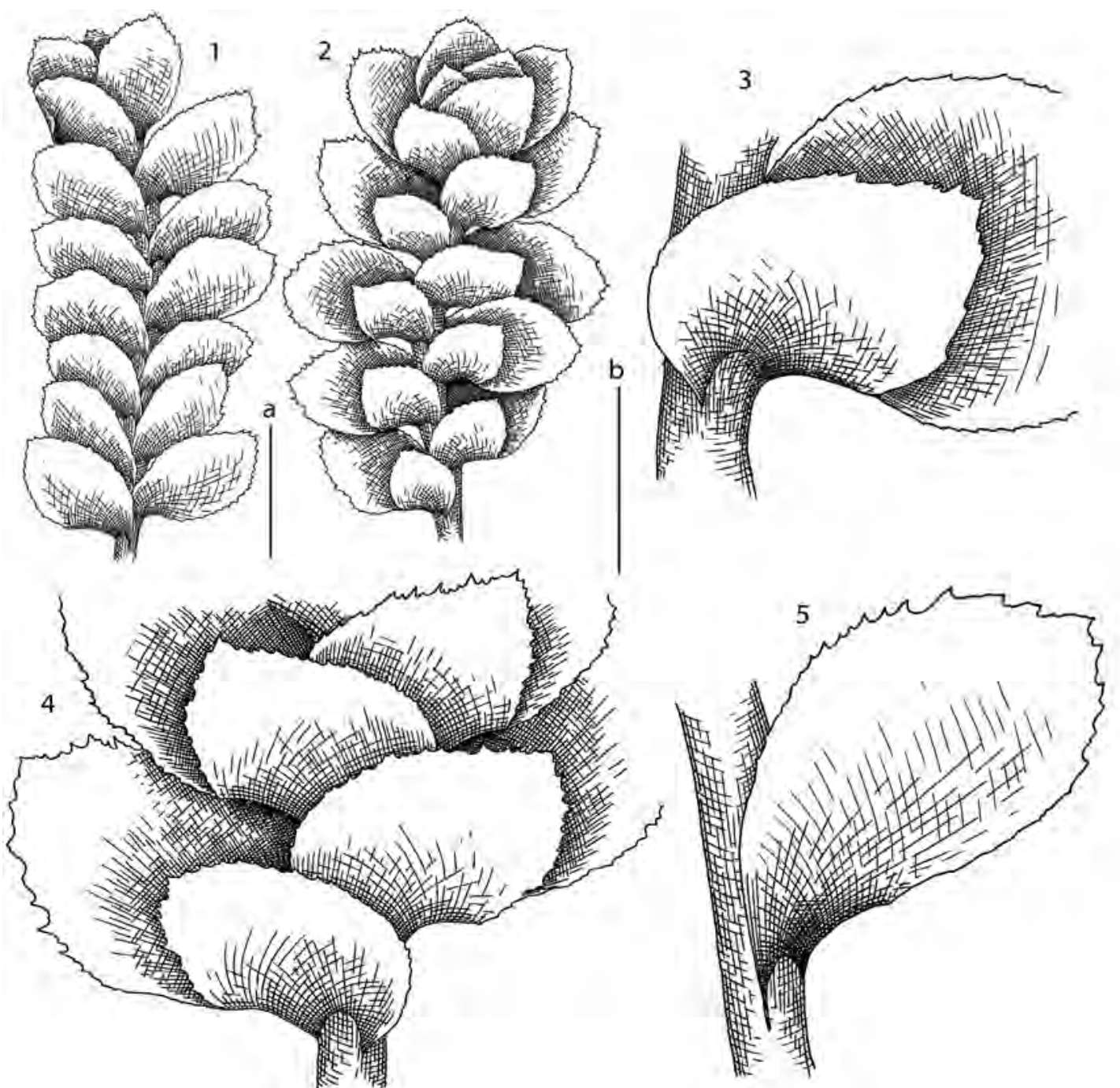

Figure 45 Scapania sphaerifera $\mathrm{H}$. Buch 1 - habit, ventral view; 2 - habit, dorsal view; 3 - dorsal lobe insertion; 4 - part of shoot, dorsal view; 5 - ventral lobe insertion. Scales: $\mathrm{a}-1 \mathrm{~mm}$, for 1,$2 ; \mathrm{b}-500 \mu \mathrm{m}$, for $3-5$.

obliquely ovate to rectangular, $1.0-1.2 \times 0.5-0.7 \mathrm{~mm}, 0.5-0.7$ of ventral in size, ca. $30-45^{\circ}$ with stem axis, margin dentate, apex obtuse to acute; ventral lobe transversely inserted, insertion line arched, decurrent, obliquely oblong to obovate, $1.2-1.5 \times 0.7-1.0 \mathrm{~mm},(0.6-0.7: 1)$, ca $30-50^{\circ}$ with stem axis, margin dentate, apex rounded, or obtuse to acute. Cells in the midleaf polygonal, 17.0-27.0 × 12.0-22.5 $\mu \mathrm{m}$ with triangular trigones; near apex 12.5-17.0 $\times 12.5-15.0 \mu \mathrm{m}$ with concave trigones; at the base $25.0-37.5 \times 17.5-22.5 \mu \mathrm{m}$ with convex trigones; cuticle strongly coarsely papillose, 2.5 $10.0 \times 2.5-7.0 \mu \mathrm{m}$. Specialized asexual reproduction by gemmae scattered to in masses at apices of leaves, spherical to (sometimes) angular, 20.0-25.0 × 12.5-17.5(-25.0) $\mu \mathrm{m}$, (2-)4-8 celled, brown. Sexual condition dioicous.

Habitat: Shaded granitic cliffs or crevices in gravelly barrens field; in tundra and Pinus pumila belts, avoid areas with strong oceanic influence in climate; 171-1500 $\mathrm{m}$ alt.

Distribution: Primorsky Territory, Sakhalin Province, Kamchatka Territory, Khabarovsk Territory, Magadan Province, Chukotka Province.

Comments: 1. We did not found the perianths in available specimens, but since it is valuable for understanding of morphology of the species, we provide here its description based on study by Konstantinova \&
Potemkin (1994: 124): "Perianth ellipsoid-cylindric, more or less flattened when mature and almost not flattened when immature, pluriplicate near mouth, with several deep plicae descending to the base. The mouth divided into many irregular ciliate-dentate sometimes incurved lobes. The teeth of lobes composed of 1 to 7 , even to 9, more or less isodiametric cells ca. 10-14 $\mu \mathrm{m}$; apical cells elongated 10.0-14.0 $\times 25.0-43.0 \mu \mathrm{m}$. Cells near the mouth thick-walled, without distinct trigones, $10.0-12.0 \mu \mathrm{m}$ ".

2. This species was previously placed in the sect. Sphaerifera (Konstantinova \& Potemkin 1994), which was described on the basis of the 4-8-celled gemmae and pluriplicate perianth. However, shape of gemmae is strongly varied both in $S$. sphaerifera and the rest bulk of sect. Aequilobae (e.g. S. verrucosa), although being presumably 4-8-celled in the former and 2-celled in the latter. The similar situation exists and with gemmae shape too, those vary from angular to elliptic and spherical, at least in the pair $S$. sphaerifera $-S$. verrucosa. The shape of perianth used as the main differentiating feature (Konstantinova \& Potemkin 1994) is not useful since discovering of perianth in $S$. simmonsii occupying morphologically intermediate position between $S$. sphaerifera and the most members of sect. Aequilobae s. str. Therefore, it seems to be practical to transfer S. sphaerifera to sect. Aequlobae, and consequently to synonymize sect. Sphaerifera with the latter.

Specimens examined: PRIMORSKY TERRITORY, Partizansky District, VB P-65-27a-06 (VBGI), VB P-58-2-08, P-58-6-08 (VBGI); SAKHALIN PROVINCE, Sakhalin Island, Nabil'sky Range, VB S-31-9-06 (VBGI); KHABAROVSK TERRITORY, Okhotsk District, VB Kh-46-6-08, Kh-46-12-08 (VBGI); KAMCHATKA TERRITORY, Central Kamchatka, Tigil’ River basin, 

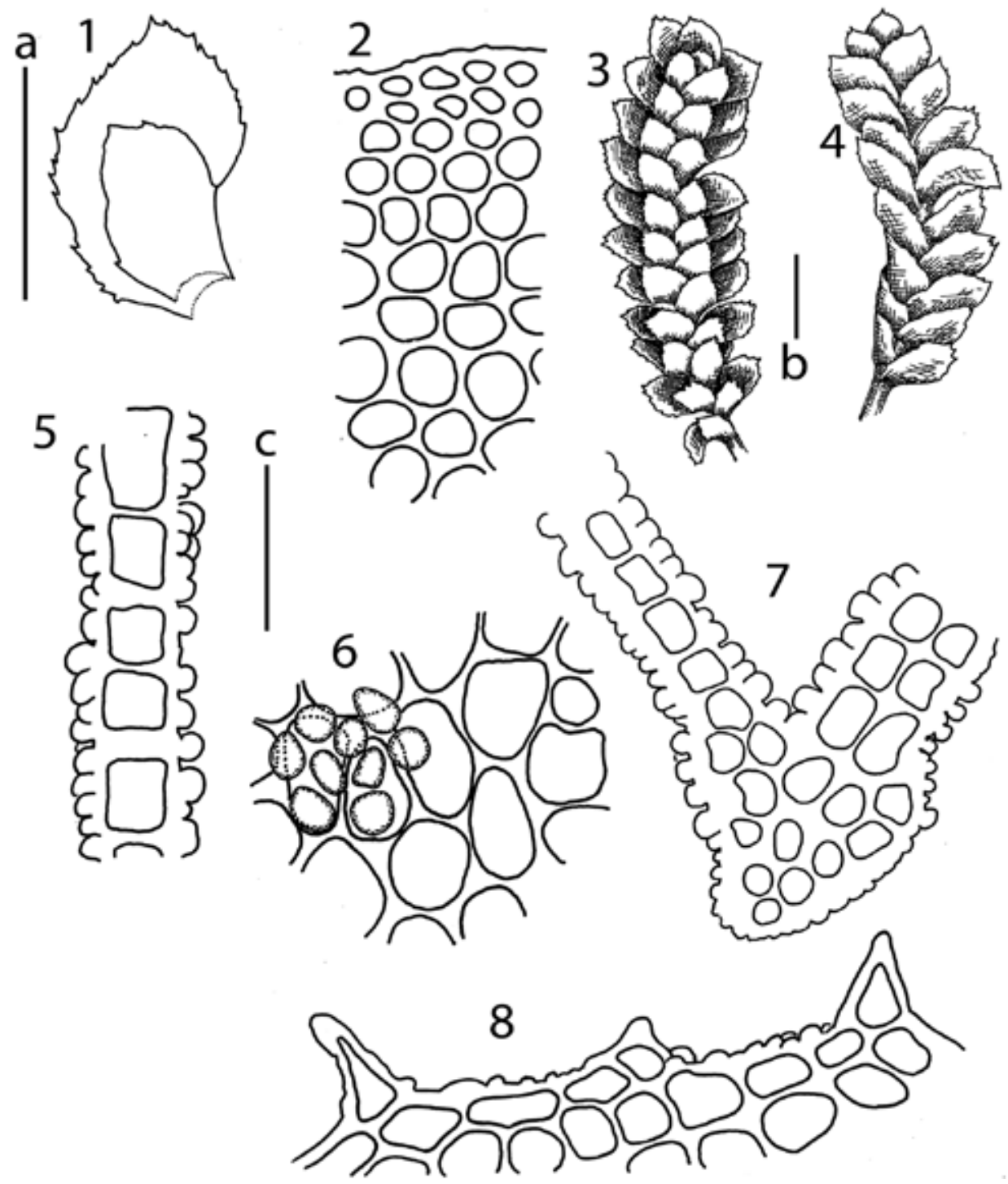

Figure 46 Scapania sphaerifera $\mathrm{H}$. Buch 1 - leaf; 2 - stem cross section, fragment; 3 - habit, dorsal view; 4 - habit, ventral view; 5 - leaf cross section, fragment; 6 - midleaf cells, partly showing papillae; 7 - keel cross section; 8 - leaf margin. Scales: $\mathrm{a}-1 \mathrm{~mm}$, for $1 ; \mathrm{b}-1 \mathrm{~mm}$, for 3,$4 ; \mathrm{c}-25 \mu \mathrm{m}$, for $2,5-8$.

VB K-132-30-04 (VBGI); MAGADAN PROVICE, Magadan City area, VB Mag-19-14-10 (VBGI), Kamennyj Range, VB Mag-2332-10, Mag-23-34-10, Mag-23-36-10, Mag-23-37-10, Mag-23-3910 (VBGI), Khasynsky District, VB Mag-11-18-10, Mag-11-32-10 (VBGI).

[4. Scapania verrucosa Heeg., Rev. Bryol. 20: 81, 1893. (Fig. 47, 52: 1)

Description: Plants $10.0-30.0 \times 2.5-3.0 \mathrm{~mm}$, ascending to erect, green. Stems sparsely branched, dorsal surface reddish brown, ventral surface brown, cross section $0.35-0.40 \times 0.25-0.30 \mathrm{~mm}$, cortex cells thick-walled in 2-4 layers, $10.0-12.5 \times 10.0-12.5 \mu \mathrm{m}$, with brown walls; inner cells larger, thin-walled, 12.5-20.0 × 10.0-12.5 $\mu \mathrm{m}$, with colorless walls. Rhizoids sparse to common, colorless. Leaves contiguous to imbricate; keel $0.4-0.5$ of ventral lobe length, usually lamellate-winged, with wing $2-5$ cells wide, straight to slightly arched, ca. $30-60^{\circ}$ with stem axis at the middle part and up to $80-110^{\circ}$ at the end; dorsal lobe transversely inserted, insertion line arched, not decurrent, obliquely rectangular, $1.0-1.2 \times 0.8-0.9 \mathrm{~mm}, 0.55-0.65$ of ventral in size, ca. $40-60^{\circ}$ with stem axis, margin denticulate, apex rounded to obtuse; ventral lobe transversely inserted, insertion line arched, decurrent for 1.5-2.0 of stem width, obliquely oblong to obovate, $1.8-2.0 \times 1.0-1.2 \mathrm{~mm},(0.5-$ $0.6: 1)$, ca. $60-70^{\circ}$ with stem axis, margin denticulate, apex rounded to obtuse. Cells in the midleaf polygonal, 18.0 $30.0 \times 12.5-27.5 \mu \mathrm{m}$ with convex trigones; near apex 7.0 $14.5 \times 7.0-13.0 \mu \mathrm{m}$, along margin with $2-3$ rows of thickwalled cells; at the base $37.5-50.0 \times 17.5-22.5 \mu \mathrm{m}$ with convex trigones; cuticle strongly coarsely verrucose, 7.5$22.5 \times 2.5-10.0 \mu \mathrm{m}$. Specialized asexual reproduction by gemmae in masses at apices of leaves, angular, 17.5-20.0 $\times 10.0-15.0 \mu \mathrm{m}, 2$-celled, yellowish green to brownish green. Sexual condition dioicous.]

Habitat: [Shaded wet rocks near stream or waterfalls; elevation unknown.]

Distribution (very doubtful): Primorsky Territory, Magadan Province.

Comments: 1 . The records of S. verrucosa from Magadan Province (Blagodatskikh \& Duda 1988) and Primorsky Territory (Potemkin 2003) are very 

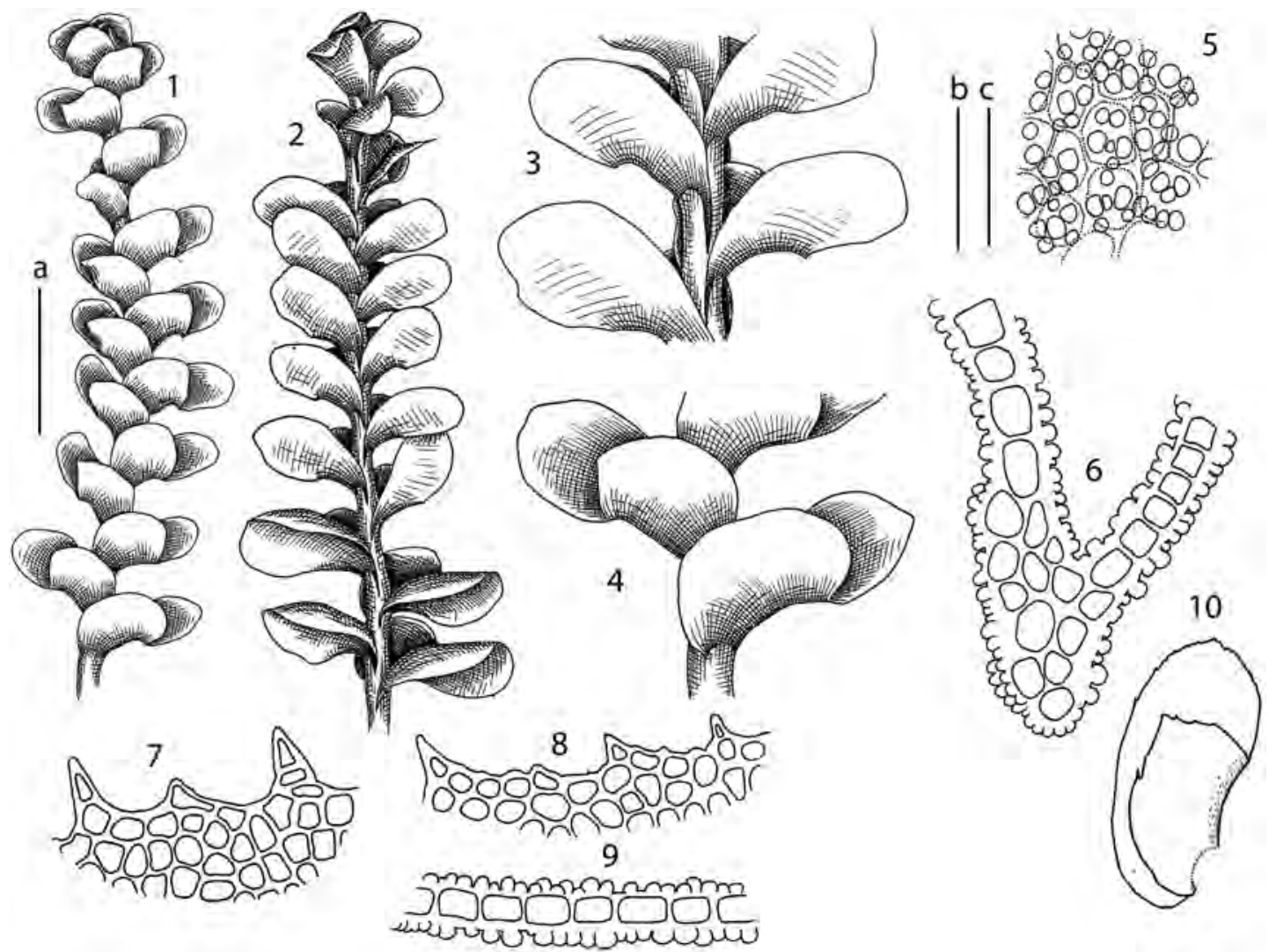

Figure 47 Scapania verrucosa Heeg. 1 - habit, dorsal view; 2 - habit, ventral view; 3 - part of shoot, ventral view; 4 - part of shoot, dorsal view; 5 - midleaf cells, showing papillae; 6 - keel cross section; 7, 8 - leaf margin; 9 - leaf cross section, fragment; 10 - leaf. Scales: $\mathrm{a}-2 \mathrm{~mm}$, for 1,$2 ; \mathrm{b}-1 \mathrm{~mm}$, for $3,4,10$; $\mathrm{c}-50 \mu \mathrm{m}$, for $5-9$.

doubtful. In our opinion, these reports should be referred to S. sphaerifera, which is similar to $S$. verrucosa and quite frequent in the treated area.

2. This species was traditionally attributed to the sect. Aequilobae based on coarsely papillose cuticle. However Potemkin (1998) paid attention to the shape of gemmae (mostly triangular) and dentate basal portion of leaf margin. He placed this taxon into the separate section, sect. Verrucosae. Since all of three taxa (S. sphaerifera, S. verrucosa and S. simmonsiz) are strongly variable in the both gemmae shape and dentation we suggest as superfluous to maintain the both sections and propose to synonymize both under older name Aequilobae.

Specimens examined: [KRASNODAR TERRITORY, Belaya River, N.A. Konstantinova K-464-01-07 (KPABG, VBGI, JNU), North-Western Caucasus, Shakhe River, N.A. Konstantinova K-429-04-08 (KPABG, VBGI, JNU), North-Western Caucasus, Teberda River Valley, N.A. Konstantinova K-459-1a-05 (KPABG, VBGI, JNU).]

MACRODIPLOPHYLLUM (H. Buch) Perss., Svensk Bot. Tidskr. 43: 507, 1949.

Diplophyllum subgen. Macrodiplophyllum H. Buch, Commentat. Biol. 3(1): 29, 1928.

Description: Plants $20.0-60.0 \times 2.0-5.0 \mathrm{~mm}$, ascending to erect, yellowish green to brownish green or olive green. Stems sparsely branched, yellowish green to fuscous brown, in cross section cortex cells thick-walled in 1-3(-4) layers. Rhizoids sparse near apex, common to numerous below, fasciculate, spreading at right angle with stem, colorless. Leaves imbricate, sheathing stem in the base; keel $0.25-0.40$ of ventral lobe length, slightly arched; dorsal lobe subtransversely inserted, insertion line weakly arched, weakly decurrent for $0.1-0.2$ of stem wide, obliquely obovate to spatulate, flat to slightly convex, $0.4-0.9$ of ventral in size; ventral lobe transversely inserted, insertion line arched, not decurrent, $0.45-0.70: 1$ as wide, margin entire to denticulate or dentate, apex rounded; cells in the midleaf polygonal with convex trigones; along margin 2-3 cell rows equally thick-walled or thin-walled; cuticle striolate to verrucose or coarsely papillose. Oil bodies (3-)5-8(10) per cells, spherical to elliptical, granulate. Specialized asexual reproduction by gemmae, scattered to in masses at apices of leaves, mostly angular, 2-4 celled, brown. Sexual condition dioicous. Gynoecia terminal, female bracts in one pair, slightly larger than sterile leaves. Perianth cylindrical, pluriplicate, weakly dorsiventrally compressed or cylindrical, mouth lobulate and densely ciliate, lobulae 6-10(-20) cells long, 1-4 cells wide.

Species 3 (3 in the flora): North America, Eurasia (Table 7).

\section{Key to the species of Macrodiplophyllum}

1. Cuticle striolate to verrucose; keel ca. $80-110^{\circ}$ with stem axis; ventral lobe $0.40-0.55$ as wide as long; margin of ventral lobe entire to denticulate

1. Cuticle strongly coarsely papillose; keel ca. $110-140^{\circ}$ with stem axis; ventral lobe 0.6-0.7 as wide as long; margin of ventral lobe dentate ........................................................ 3. M. microdontum.

2. Dorsal lobe $0.8-0.9$ of ventral lobe size; margin of ventral lobe entire, cells along margin $8.0-13.0 \mu \mathrm{m}$; stem cross section with $1-2$ outer layers thick-walled, mostly with thin-walled external wall [in treated area it is found in Commanders only] ...................................... 1. M. imbricatum.

2. Dorsal lobe $0.4-0.5$ of ventral lobe size; margin of ventral lobe denticulate, cells along margin ca. 10.0-16.0 $\mu \mathrm{m}$; stem cross section with 2-4 outer layers thick-walled, with external wall thickened too [common in treated area ] ................................. 2. M. plicatum. 
Table 7. Comparison of Species of Macrodiplophyllum

\begin{tabular}{|l|c|c|c|}
\hline Characters & M. plicatum & M. imbricatum & M. microdontum \\
\hline Cuticle & striolate to verrucose & striolate to weakly verrucose & coarsely papillose \\
\hline $\begin{array}{l}\text { Thick-walled cell rows along margin in } \\
\text { stem cross section }\end{array}$ & $2-4$ & $1-2(-3)$ & $2-4$ \\
\hline Dorsal lobe of ventral lobe size & $0.4-0.5$ & $0.8-0.9$ & $0.5-0.6$ \\
\hline Ventral lobe as wide as long & $0.45-0.55$ & $0.40-0.50$ & $0.60-0.70$ \\
\hline Margin near apex of ventral lobe & denticulate & entire & dentate \\
\hline Keel angle with stem at the midleaf & $80-100^{\circ}$ & $90-110^{\circ}$ & $110-140^{\circ}$ \\
\hline
\end{tabular}

1. Macrodiplophyllum imbricatum (M.A. Howe) Perss., Svensk Bot. Tidskr. 43: 508, 1949.

Scapania imbricata M.A. Howe, Bull. New York Bot. Gard. 2(6): 104, 1901.

Diplophyllum imbricatum (M.A. Howe) Müll. Frib. in Steph., Sp. Hepat. 4: 113, 1910. (Fig. 48)

Description: Plants $10.0-40.0 \times 2.5-3.2 \mathrm{~mm}$, ascending to erect, olive green to brownish green. Stems sparsely branched, olive green near apex and fuscous brown below, cross section $0.25-0.35 \times 0.40-0.45 \mathrm{~mm}$, cortex cells thick-walled in 1-2(-3) layers, $12.5-15.0 \times 7.5-12.5 \mu \mathrm{m}$ with brown walls, external wall of outer row commonly thin; inner cells larger, thin-walled, with concave trigones, $12.5-30.0 \times 15.0-20.0 \mu \mathrm{m}$ with colorless walls. Rhizoids sparse to common, fasciculate, spreading at right angle with stem, colorless. Leaves imbricate; keel 0.3-0.4 of ventral lobe length, not winged, ca. 10$30^{\circ}$ with stem axis at the base and gradually incurved up to $90-110^{\circ}$ at the end; dorsal lobe subtransversely inserted, insertion line weakly arched, not decurrent, obliquely obovate to spatulate, slightly convex, arching over stem and farther beyond stem, $1.1-1.5 \times 0.6-0.7 \mathrm{~mm}, 0.8-0.9$ of ventral in size, ca. $30-50^{\circ}$ with stem axis, margin entire, apex rounded; ventral lobe transversely inserted, insertion line arched, not decurrent, obliquely obovate to spatulate, slightly falcate, slightly convex, $1.6-1.8 \times 0.7-0.8 \mathrm{~mm},(0.4-0.5: 1)$, ca. 60 $80^{\circ}$ with stem axis, margin entire, apex rounded. Cells in the midleaf polygonal, $25.0-35.0 \times 20.0-29.0 \mu \mathrm{m}$ with convex trigones; in apex rectangular, $7.5-12.5 \times 12.5-17.5 \mu \mathrm{m}$; along margin with $2-3$ cell rows equally thick-walled; at the base polygonal, $62.5-85.0 \times 20.0-25.0 \mu \mathrm{m}$ with convex trigones; cuticle striolate to weakly verrucose. Specialized asexual reproduction by gemmae in scattered to masses at apices of leaves, spherical to angular, $15.0-25.0 \times 15.0-25.0 \mu \mathrm{m}, 2-4$ celled, brown. Sexual condition dioicous.

Habitat: Shaded rocks in stony fields or crevices in gravelly barrens field; in tundra zone; $200 \mathrm{~m}$ alt.

Distribution: Kamchatka Territory.

Specimens examined: KAMCHATKA TERRITORY, Commanders, Bering Island, VB 07.VIII.2002 (KPABG, VBGI), VB 11.VIII.2002 (KPABG).
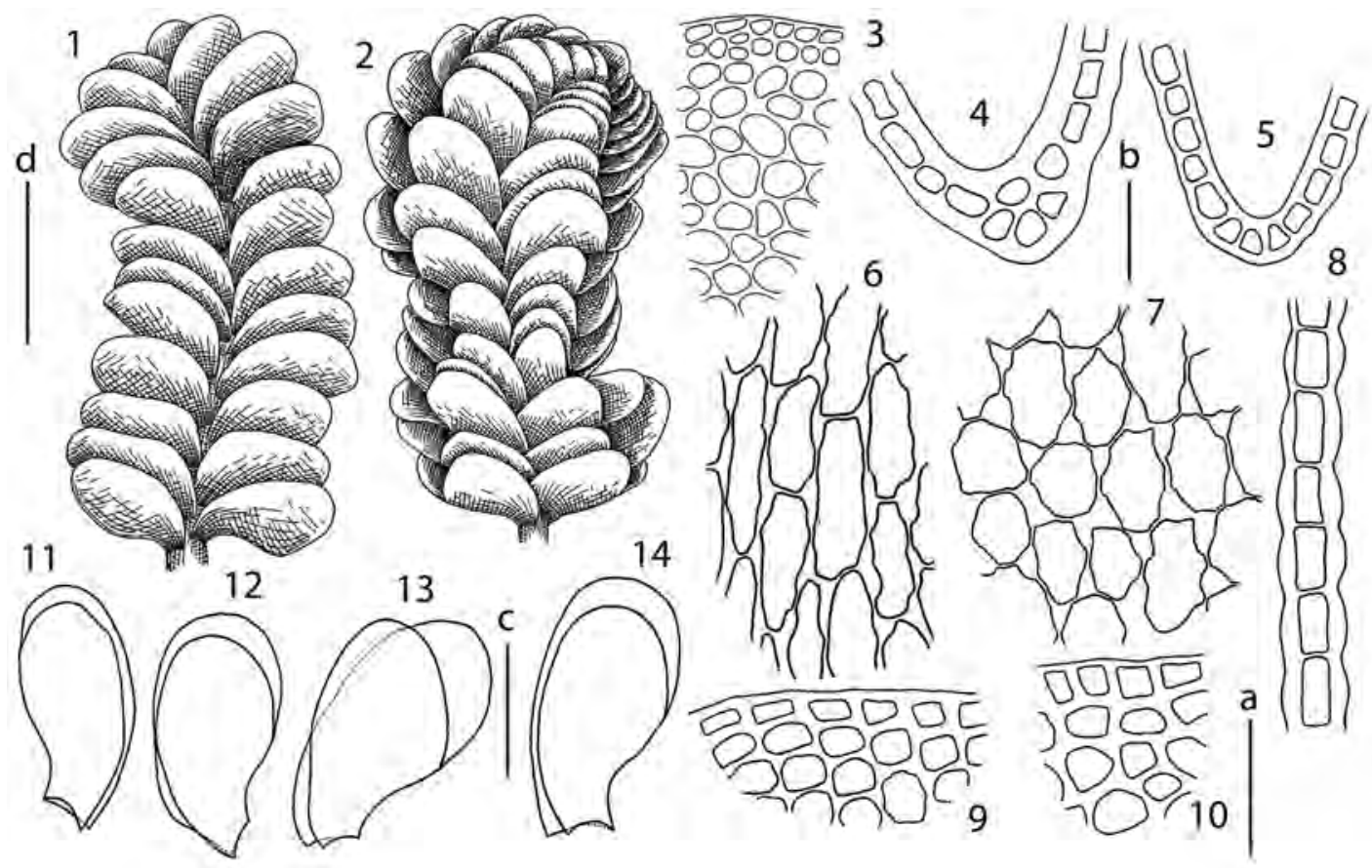

Figure 48 Macrodiplophyllum imbricatum (M. A. Howe) Perss. 1 - habit, ventral view; 2 - habit, dorsal view; 3 - stem cross section, fragment; 4,5 - keel cross section; 6 - leaf base cells; 7 - midleaf cells; 8 - leaf cross section, fragment; 9,10 - leaf margin. Scales: $\mathrm{a}-50 \mu \mathrm{m}$, for $6-10 ; \mathrm{b}-50 \mu \mathrm{m}$, for 4,5 ; c $-500 \mu \mathrm{m}$, for $11-14 ; \mathrm{d}-1 \mathrm{~mm}$, for 1,2 . 
2. Macrodiplophyllum plicatum (Lindb.) Perss., Svensk Bot. Tidskr. 43: 507, 1949.

Diplophyllum plicatum Lindb., Acta Soc. Sci. Fenn. 10: 235, 1872.

Scapania plicata (Lindb.) Potemkin, Ann. Bot. Fenn. 36: 281, 1999. (Fig. 49, 50, 52: 9)

Description: Plants $20.0-60.0 \times 2.0-4.8 \mathrm{~mm}$, ascending to erect, yellowish green to brownish green. Stems sparsely branched, yellowish green near apex and fuscous brown below, cross section $0.30-0.35 \times 0.40-0.45 \mathrm{~mm}$, cortex cells thick-walled in 2-4 layers, $10.0-17.5 \times 7.5-12.5 \mu \mathrm{m}$ with brown walls; inner cells larger, thin-walled, with concave trigones, $12.5-25.0 \times 12.5-20.0 \mu \mathrm{m}$ with colorless walls. Rhizoids sparse near apex and common to numerous below, fasciculate, spreading at right angle with stem, colorless. Leaves contiguous to imbricate; keel $0.3-0.4$ of ventral lobe length, not winged, slightly arched, ca. $10-30^{\circ}$ with stem axis near base and gradually incurved up to $80-100^{\circ}$ at the end; dorsal lobe subtransversely inserted, insertion line weakly arched, weakly decurrent for $0.1-0.2$ of stem width, obliquely obovate to spatulate, flat to slightly convex, arching over stem and farther beyond stem, 1.2-1.6 $\times 0.5$ $0.8 \mathrm{~mm}, 0.4-0.5$ of ventral in size, ca. $35-50^{\circ}$ apex with stem axis, margin entire to denticulate with rounded apex; ventral lobe transversely inserted, insertion line arched, not decurrent, obliquely obovate to spatulate, weakly falcate, slightly convex, $2.0-2.8 \times 0.9-1.4 \mathrm{~mm},(0.45-0.55: 1)$, ca $70-85^{\circ}$ with stem axis, margin entire to denticulate apex rounded. Cells in the midleaf polygonal, 18.0-32.5 $\times$ $17.0-25.0 \mu \mathrm{m}$ with convex trigones; in apex 10.0-15.0 $\times$ $10.0-15.0 \mu \mathrm{m}$; along margin with $2-3$ cell rows of equally thick-walled cells; at the base 30.0-75.0 × 17.5-35.0 $\mu \mathrm{m}$ with convex trigones; cuticle striolate to verrucose. Oil bodies $5-8(-10)$ per cells, spherical to elliptical, granulate. Specialized asexual reproduction by gemmae, scattered to in masses at apices of leaves, spherical to angular, 25.0 $37.5 \times 12.5-17.5 \mu \mathrm{m}, 2-4$-celled, brown. Sexual condition dioicous. Gynoecia terminal, female bracts in one pair, slightly larger than sterile leaves, dorsal lobe 1.4-1.7 $\times$ 0.6-0.8 mm; ventral lobe 2.6-2.9 × 1.0-1.4 mm. Perianth cylindrical, pluriplicate, weakly dorsiventrally compressed, $4.0-5.0 \times 1.0-1.2 \mathrm{~mm}$, mouth lobulate-ciliate, lobulae 6-10(-20) cells long, 1-4 cells wide.

Habitat: Shaded rocks, crevices in gravelly barrens fields, humus along stream bed or coniferous forest floor; 10-1600 m alt.

Distribution: Primorsky Territory, Khabarosk Territory, Sakhalin Province, Kurile Islands, Kamchatka Territory, Magadan Province, Chukotka Province; the taxon is one of the most common species in treated area, especially in its southern half.

Specimens examined: SAKHALIN PROVINCE, Shikotan Island, VB K-53-4-07 (VBGI), VB K-57-25-07 (VBGI), Sakhalin Island, Pormr' Bay, VB S-33-9-09 (VBGI), Kamyshovyj Range, VB S-57-9-09 (VBGI), KHABAROVSK TERRITORY, Ul'chinsky District, I.F. Skirina 03.VIII.2005 sine n. (VBGI), Okhotsk District, VB Kh-24-19-08 (VBGI), VB Kh-30-4-08 (VBGI).

3. Macrodiplophyllum microdontum (Mitt.) Perss., Svensk Bot. Tidskr. 43: 507, 1949.

Martinellius microdontus Mitt. Trans. Linn. Soc. London, Bot. 3: 196, 1891.

Diplophyllum microdontum (Mitt.) H. Buch, Commentat. Biol. 3(1): 31, 1928.

Scapania microdonta (Mitt.) Müll. Frib, Nova Acta Acad.

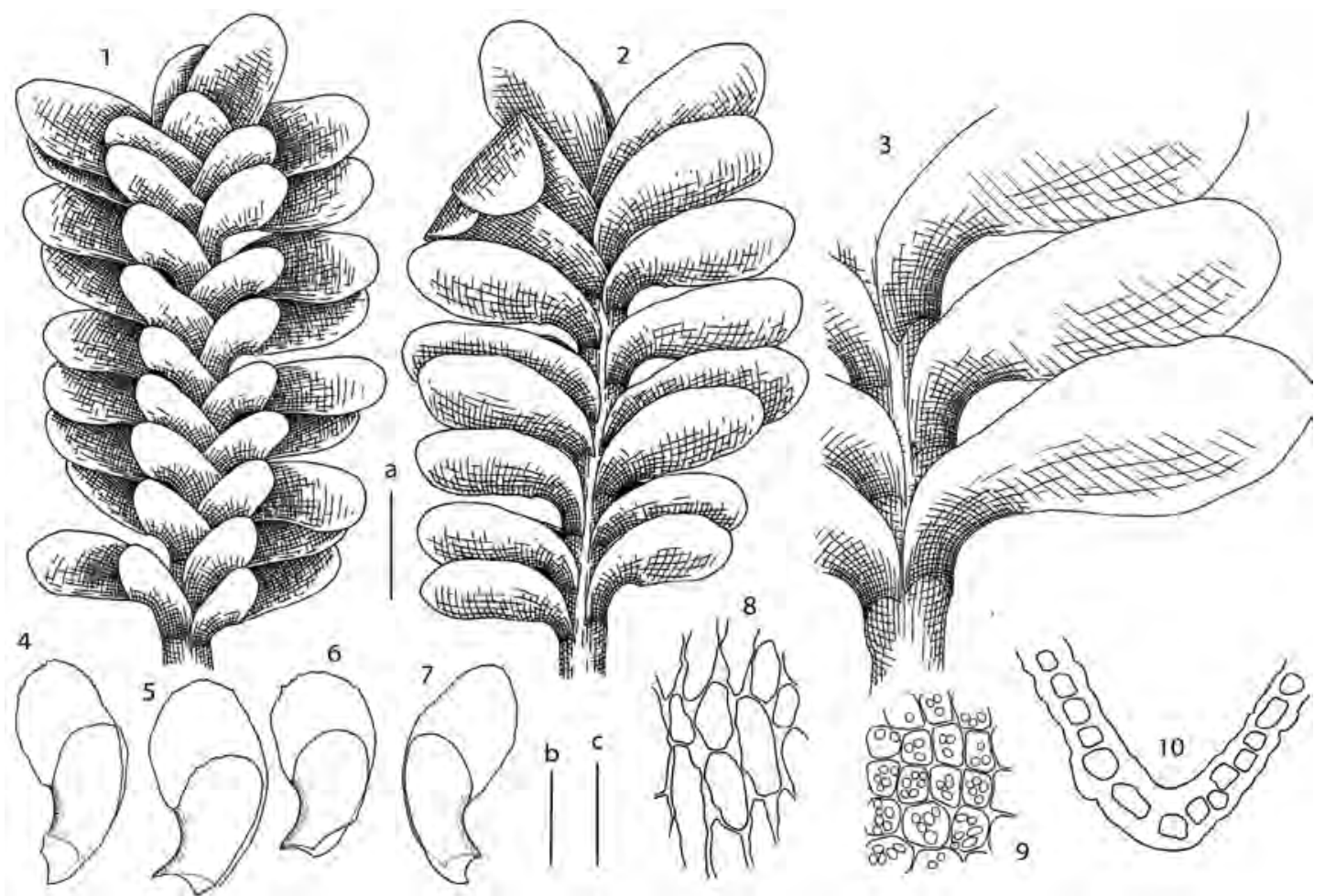

Figure 49 Macrodiplophyllum plicatum (Lindb.) Perss. 1 - habit, dorsal view; 2 - habit, ventral view; 3 - part of shoot, ventral view; 4-7 - leaves; 8 - leaf base cells; 9 - midleaf cells, showing papillae; 10 - keel cross section. Scales: a -1 $\mathrm{mm}$, for $1,2,4-7 ; \mathrm{b}-500 \mu \mathrm{m}$, for 3 ; $\mathrm{c}-50 \mu \mathrm{m}$, for $8-10$. 

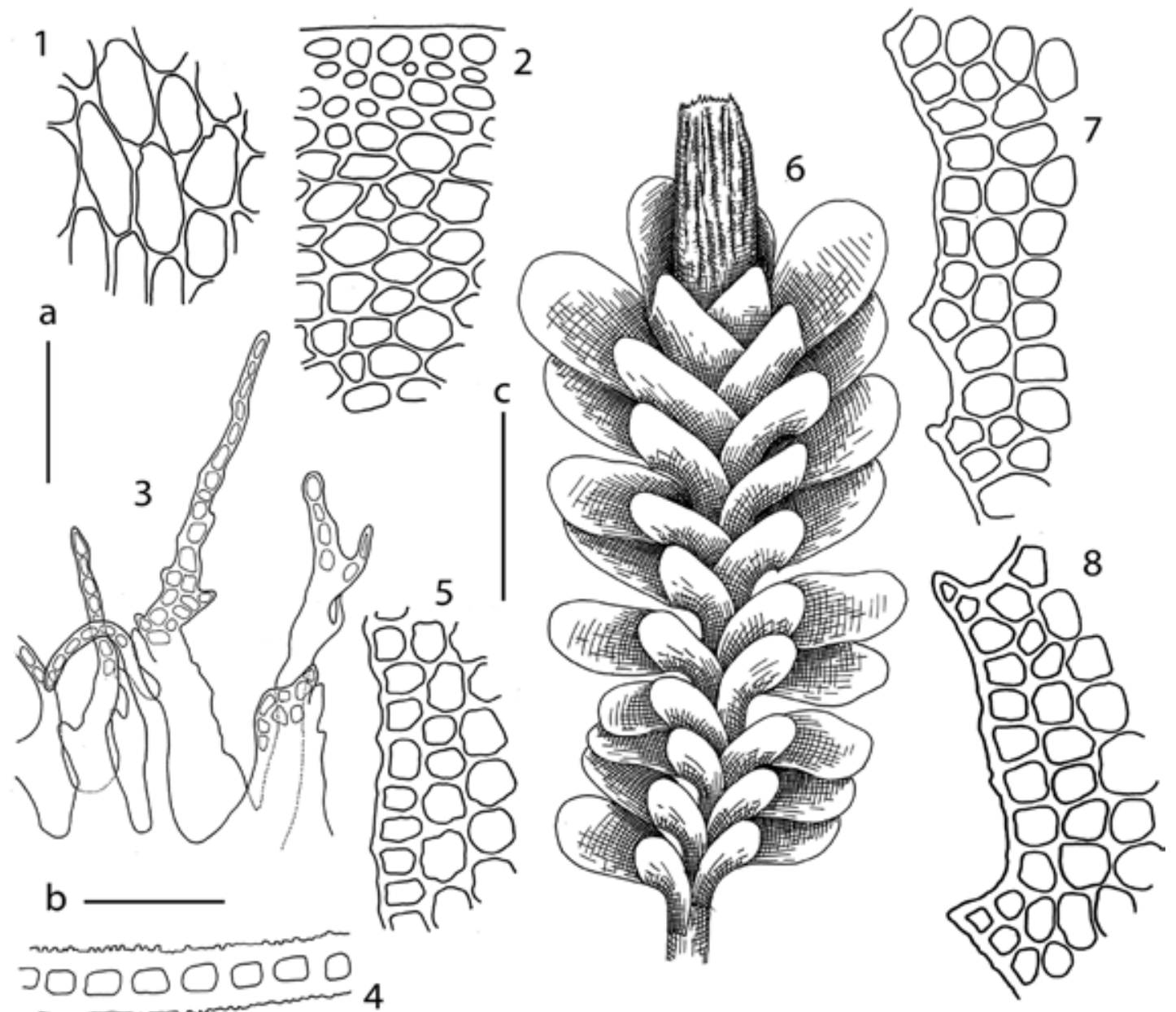

Figure 50 Macrodiplophyllum plicatum (Lindb.) Perss. 1 - leaf base cells; 2 - stem cross section, fragment; 3 - perianth mouth armature, fragment; 4 - leaf cross section, fragment; 5, 7, 8 - leaf margin; 6 - perianthous plant, dorsal view. Scales: $\mathrm{a}-50 \mu \mathrm{m}$, for $1,2,4,5,7,8 ; \mathrm{b}-100 \mu \mathrm{m}$, for $3 ; \mathrm{c}-2 \mathrm{~mm}$, for 6 .

Caes. Leop.-Carol. German. Nat. Cur. 83: 262, 1905. (Fig. 51, 52: 16)

Description: Plants 30.0-70.0 × 4.0-4.4 mm, ascending to erect, yellowish green to brownish green or fuscous brown. Stems sparsely branched, yellowish green near apex and fuscous brown below, cross section $0.30-0.35 \times 0.50$ $0.55 \mathrm{~mm}$, cortex cells thick-walled in 2-4 layers, 12.5-17.5 $\times 10.0-15.0 \mu \mathrm{m}$ with brown walls; inner cells larger, thinwalled, with concave trigones, $20.0-30.0 \times 12.5-20.0 \mu \mathrm{m}$ with colorless walls. Rhizoids sparse to common, isolate to fasciculate, spreading at right angle with stem, colorless. Leaves closely imbricate; keel $0.25-0.35$ of ventral lobe length, not winged, semicircularly arched, ca. $30-50^{\circ}$ with stem axis at the base and gradually incurved up to $110-140^{\circ}$ at the end; dorsal lobe subtransversely inserted, insertion line slightly arched, weakly decurrent for $0.1-0.2$ of stem width, obliquely oblong to ovate, slightly convex, arching over stem and farther beyond stem, antical base obliquely auriculate to circinate, $1.6-2.0 \times 0.8-1.0 \mathrm{~mm}, 0.5-0.6$ of ventral in size, ca. $35-50^{\circ}$ apex with stem axis, margin dentate, apex rounded; ventral lobe transversely inserted, insertion line arched, decurrent for $0.1-0.2$ of stem wide, obliquely oblong to obovate, slightly convex, $2.0-2.6 \times$ $1.2-1.6 \mathrm{~mm},(0.6-0.7: 1)$, ca. $70-85^{\circ}$ near apex with stem axis, margin dentate, apex rounded. Cells in the midleaf polygonal, $25.0-37.5 \times 25.0-30.0 \mu \mathrm{m}$ with convex trigones; in apex 12.5-17.5 × 12.5-20.0 $\mu \mathrm{m}$ with convex trigones; at the base $50.0-62.5 \times 20.0-25.0 \mu \mathrm{m}$ with convex trigones; cuticle coarsely papillose. Oil bodies $4-6(-8)$ per cells, spherical to elliptical, $5.5-7.5 \times 5.0-6.0 \mu \mathrm{m}$ granulate. Specialized asexual reproduction by gemmae, scattered to in masses at apices of shoots, spherical to angular, 20.0-25.0 × 20.0-25.0 $\mu \mathrm{m}, 2-4$ celled, brown. Sexual condition dioicous.

Habitat: Shaded rocks, crevices in gravelly barrens field or cliffs in tundra or gravelly barrens belt; 500-1600 m alt.

Distribution: Primorsky Territory, Khabarosk Territory, Sakhalin Province, Kamchatka Territory, Magadan Province, Chukotka Province.

Comments. The characters of perianth and gemmae are important to divide Scapania and Macrodiplophyllum in morphological respect. M. microdontum has deeply plicate, long emergent perianth and angular to almost stellate gemmae which refer it to genus $\mathrm{Mac}$ rodiplophyllum. Despite molecular data shows its presence within Scapania (Vilnet et al. 2010; Heinrichs et al. 2012) we prefer to keep it within Macrodiplophyllum.

Specimens examined: PRIMORSKY TERRITORY, Shkotovsky District, VB (VBGI), VB P-57-1-08 (VBGI); SAKHALIN PROVINCE, Nabil'sky Range, V.A.Bakalin S-31-14-06, S-31-15-06 (VBGI); KHABAROVSK TERRITORY, Verkhnebureinskij District, G.N. Kurilin VII.2009 sine n. (VBGI), Solnechnyj District, VB Kh-5-52-07 (VBGI); KAMCHATKA TERRITORY, Central Kamchatka, Tigil' River basin, VB K-132-38-04 (VBGI); MAGADAN PROVINCE, Magadan City area, VB Mag-23-35-10 (VBGI). 


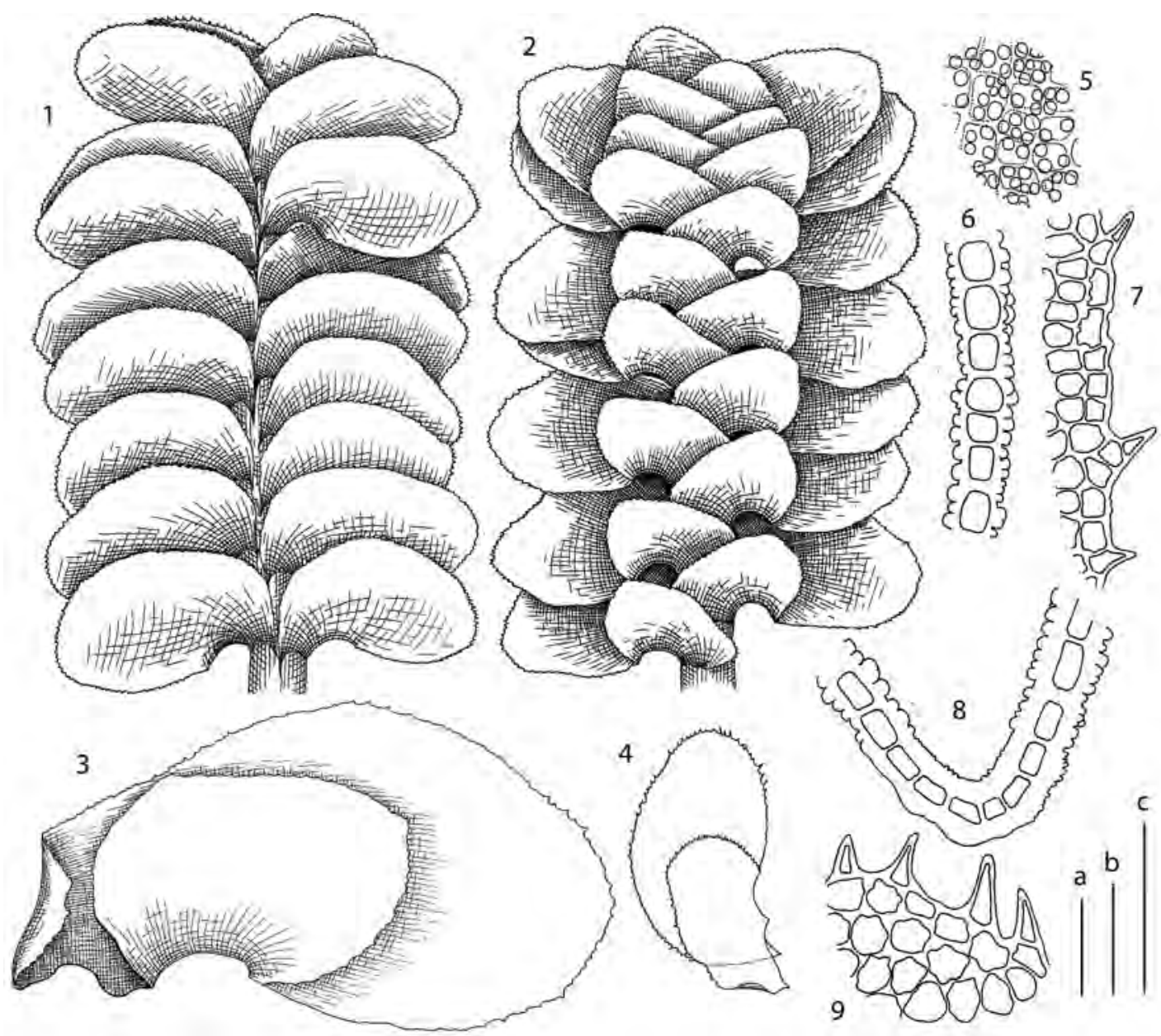

Figure 51 Macrodiplophyllum microdontum (Mitt.) Perss. 1 - habit, ventral view; 2 - habit, dorsal view; 3, 4 - leaves; 5 midleaf cells, showing papillae; 6 - leaf cross section, fragment; 7,9 - leaf margin; 8 - keel cross section. Scales: a -50 $\mu \mathrm{m}$, for $5-9 ; \mathrm{b}-500 \mu \mathrm{m}$, for $1,2,4 ; \mathrm{c}-50 \mu \mathrm{m}$, for 3 .

\section{DISTRIBUTION PATTERNS}

\section{Altitudinal trends in distribution}

The available data (Table 8) did not provide sufficient reliable information on the altitudinal range trends for most taxa within the Russian Far East. We suggest the following three possible reasons for this: 1) inadequate data to make predictions, 2) unpredictability of the general species distribution, 3) the local climate variability in micro-niches.

Being small plants, Scapania are able to find appropriate microhabitats even in the communities that are not characteristic for them. In addition, most of Scapania grow and spread along the sides of streams, and it results in invading of many arctic-alpine species to coniferous or broad-leaved forest communities. Perhaps the best example of this is the record of $S$. rufidula in a broad-leaved forest belt in the southern border of the Primorsky Territory.

On the other hand, the local climate variability is higher in regions adjacent to the seashore and/or situated in mountainous areas. The biota of such areas experiences the influence of thermal inversions, which often determine community types. The lowered tundras (particularly those near the sea) are very common in insular and peninsular areas, and this is reflected in the occurrence of some species at unusually low altitudes. The following example is rather illustrative: in the lowlands of northern Kamchatka, one of authors (VB) has frequently observed situations in which Betula ermanii Cham. forest was replaced with the dwarfshrub-moss community (so-called inverse tundras) within 10-15 km from the sea coast. Crooked forest (formed by Pinus pumila (Pall.) Regel) occupies there next altitudinal level, then it passes into normal birch forest, then again to $P$. pumila and eventually to mountain tundra (Bakalin, 2009). In these inverse tundras (situated far south of typical lowland tundras and reaching the South Kurils, at about $45^{\circ} \mathrm{N}$ ), we were able to collect many arctic-alpine species of hepatics, such as Anthelia juratzkana (L.) Dumort. and Pleurocladula albescens (Hook.) Grolle, as well as some Scapania (S. byperborea, S. paludicola, S. subalpina, and S. paludosa).

Another climatic feature of the areas adjacent to the sea is severe wind conditions. Constantly windy weather on the beaches of the Kurils Islands, Commander Archipelago, and southern Kamchatka Peninsula, which reach gale-level forces monthly, does not permit the survival of any plants taller than approximately $40 \mathrm{~cm}$ high. Such communities sometimes include mixtures of temperate and arctic elements, including both bryophytes and vascular plants, which have been described previously by Bakalin et al. (2009). 
Table 8. Altitudinal Distribution of the Species Based on Specimens Examined ( $\mathrm{m}$ alt.)

\begin{tabular}{|c|c|c|c|c|c|c|}
\hline & $\begin{array}{l}\text { Primorsky } \\
\text { Territory }\end{array}$ & $\begin{array}{c}\text { Khabarovsky } \\
\text { Territory }\end{array}$ & $\begin{array}{l}\text { Amursky } \\
\text { Province }\end{array}$ & Sakhalin Province & $\begin{array}{c}\text { Kamchatka } \\
\text { Territory }\end{array}$ & $\begin{array}{l}\text { Magadan } \\
\text { Province }\end{array}$ \\
\hline \multicolumn{7}{|c|}{ Scapania sect. 1. Curtae } \\
\hline S. curta & & & & $15-1406$ & 14-1054 & 171 \\
\hline S.parvifolia & & & & $18-1600$ & & \\
\hline S. diplophylloides & 535 & & & $100-1174$ & & \\
\hline S. lingulata & 444 & $64-115$ & & $18-1114$ & $100-1100$ & $15-1000$ \\
\hline S. mucronata & & & & & & $500-1150$ \\
\hline S. praetervisa & & & & $18-1600$ & & \\
\hline S. scandica & & 321 & & $68-161$ & & 500 \\
\hline S. irrigua & & $124-980$ & & $2-1453$ & $100-1400$ & $15-310$ \\
\hline S. obcordata & & 115-399 & & & & \\
\hline S. magadanica & & & & & & $300-621$ \\
\hline \multicolumn{7}{|l|}{ Sect. 2. Stephania } \\
\hline S. birosakiensis & & & & $15-200$ & & \\
\hline S.parvidens & & & & $18-1600$ & & \\
\hline S. parvitexta & 413 & & & & & \\
\hline \multicolumn{7}{|l|}{ Sect. 3. Kaalaasia } \\
\hline S.gymnostomophilla & & & 900 & $600-900$ & 1150 & $1000-1150$ \\
\hline \multicolumn{7}{|l|}{ S. ligulifolia } \\
\hline \multicolumn{7}{|c|}{ Sect. 4. Scapaniella } \\
\hline S. glaucocephala & & & & & 450 & \\
\hline \multicolumn{7}{|l|}{ S. zemliae } \\
\hline \multicolumn{7}{|c|}{ Sect 5. Apiculatae } \\
\hline S. apiculata & & $418-980$ & & 161 & & \\
\hline S. brevicaulis & & & & & 1000 & 1050 \\
\hline S. carinthiaca & 850 & 550 & & & & \\
\hline \multicolumn{7}{|c|}{ Sect. 6. Hyperborea } \\
\hline S. byperborea & & 494 & & 98 & $14-1300$ & \\
\hline S. degenii & & & & & & $1100-1150$ \\
\hline S. tundrae & & & & & 1000 & \\
\hline S. paludicola & & $64-494$ & & $8-728$ & $40-1199$ & $387-1056$ \\
\hline \multicolumn{7}{|c|}{ Sect. 7. Compactae } \\
\hline S. kaurinii & & & & 1300 & $1000-1400$ & \\
\hline \multicolumn{7}{|c|}{ Sect. 8. Cuspiduligerae } \\
\hline S. cuspiduligera & & & & 1263 & & 1050 \\
\hline \multicolumn{7}{|c|}{ Sect. 9. Umbrosae } \\
\hline S. umbrosa & & & & 60 & 1400 & \\
\hline \multicolumn{7}{|c|}{ Sect. 10. Undulatae } \\
\hline S. undulata & $200-1500$ & 54 & & 20-200 & 22 & 513 \\
\hline S. subalpina & 1500 & $64-321$ & & $43-1300$ & $14-1400$ & $15-296$ \\
\hline S. obscura & & & & & $300-1400$ & \\
\hline \multicolumn{7}{|l|}{ S. uliginosa } \\
\hline S.paludosa & & & & 43-1174 & $40-1400$ & \\
\hline S. rufidula & $399-530$ & 1420 & & & & $1400-1900$ \\
\hline S. spitsbergensis & & & & & & 500 \\
\hline \multicolumn{7}{|c|}{ Sect. 11. Nemorosae } \\
\hline S. crassiretis & 699-1800 & 1220 & & $1263-1300$ & & \\
\hline \multicolumn{7}{|c|}{ Sect. 12. Aequilobae } \\
\hline S. sphaerifera & $1343-1500$ & 220 & & 1406 & 450 & $171-1350$ \\
\hline \multicolumn{7}{|l|}{ S. verrucosa } \\
\hline S. ciliata & 400 & & & & & \\
\hline S. simmonsii & & & & & & 150 \\
\hline \multicolumn{7}{|c|}{ Macrodiplophyllum } \\
\hline M. imbricatum & & & & & 200 & \\
\hline M. microdontum & 1200 & & & $1200-1500$ & $900-1600$ & 500 \\
\hline M. plicatum & $800-1300$ & $50-700$ & & $10-1000$ & $10-1600$ & \\
\hline
\end{tabular}




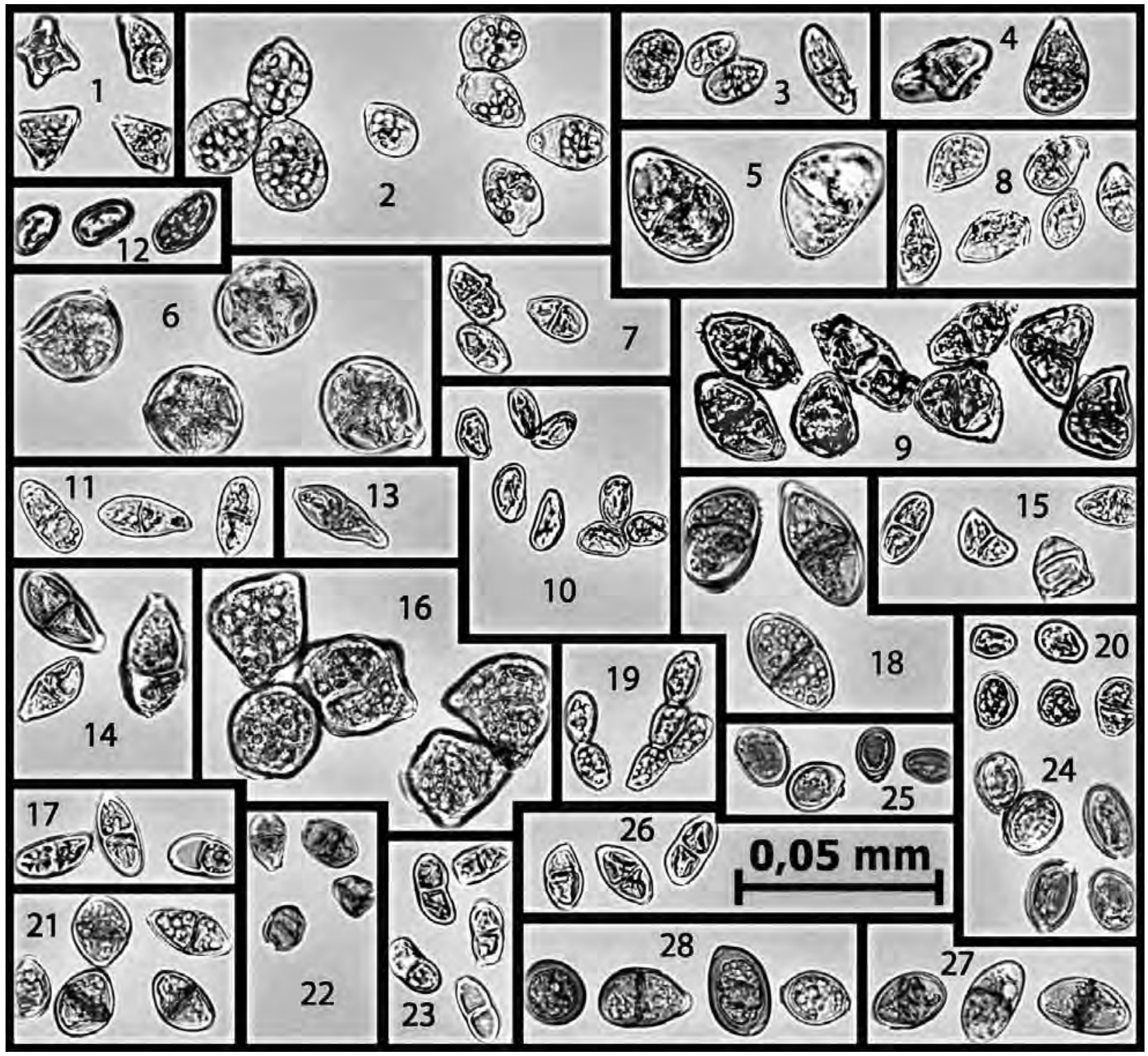

Figure 52 Gemmae of Scapania and Macrodiplophyllum. 1 - Scapania verrucosa Heeg.; 2 - Scapania undulata (L.) Dumort.; 3 - Scapania umbrosa (Schrad.) Dumort.; 4 - Scapania tundrae (Arnell) H. Buch; 5 - Scapania subalpina (Nees ex Lindenb.) Dumort.; 6 - Scapania sphaerifera H. Buch; 7 - Scapania scandica (Arnell \& H.Buch) Macvicar; 8 - Scapania praetervisa Meyl.; 9 - Macrodiplophyllum plicatum (Lindb.) Perss.; 10 - Scapania parvitexta Steph.; 11 - Scapania parvifolia var. grandiretis Schljakov; 12 - Scapania parvidens Steph.; 13 - Scapania paludicola Loeske \& Müll. Frib.; 14 - Scapania obcordata (Berggr.) S.W. Arnell; 15 - Scapania mucronata H. Buch; 16 - Macrodiplophyllum microdontum (Mitt.) Perss.; 17 - Scapania lingulata H. Buch; 18 - Scapania ligulifolia R.M. Schust.; 19 - Scapania integerrima Steph.; 20 - Scapania birosakiensis Steph.; 21 - Scapania gymnostomophila Kaal.; 22 - Scapania glaucocephala (Tayl.) Aust.; 23 - Scapania diplopbylloides Amakawa et S. Hatt.; 24 - Scapania crassiretis Bryhn; 25 - Scapania carinthiaca J.B. Jack ex Lindb.; 26 - Scapania curta (Mart.) Dumort.; 27 - Scapania cuspiduligera (Nees) Müll. Frib.; 28 - Scapania brevicaulis Tayl.

The aforementioned features result in «eury-altitudinality» of the majority of species, but that is not universal for Scapania and Macrodiplophyllum species. The obligate (or almost so) epixylous and gravelly barrens epilithic species show more distinct patterns in their altitudinal distributions. The distributions of Scapania apiculata, $S$. carinthiaca, and $S$. birosakiensis are confined to spruce-fir forests, and thus these species do not reach higher elevations. One notable exception is the puzzling distribution of $S$. glaucocephala in the Russian Far East. This species is restricted to the communities of Populus suaveolens Fisch. and Chosenia arbutifolia (Pall.) A.K. Skvortsov in floodplain forests in central Kamchatka. Contrary, outside of the Russian Far East the species is uniformly limited to Picea and Abies forests. This observation supports the hypothesis that floodplain communities are relicts of warmer, so-called Arcto-Tertiary flora (Kharkevich 1984, Bakalin 2009). Similarly, epilithic species whose distributions are not related to running water, such as S. gymnostomophila, S. kaurinii, S. cuspiduligera, S. sphaerifera, and Macrodiplophylum microdontum, are restricted to higher elevations and do not descend to forest belts in our area. Scapania magadanica, which is described herein, also appears to belong to this group.

\section{Geographical pattrens}

In general, the taxonomic diversity of Scapania and Macrodiplophyllum is mostly confined to oceanic and suboceanic mountainous areas in the Arctic, Boreal Atlantic, and Pacific 
regions, with many species spreading inland to mountain ranges (e.g., the Alps, Appalachians, Rocky Mountains, Ural, the complex of the Transbaikalian ranges), while only a few taxa are distributed throughout circumboreal lowland landscapes. South of this zone, the most notable diversity centers are the Himalayas and temperate to subtropical suboceanic to oceanic Eastern Asia. A very limited number of taxa occur outside of the areas mentioned above (cf. Potemkin 2001). Within the Russian Far East we were able to find both hemiarctic taxa as well as some of the small, but welldefined East Asian sect. Stephania. The latter is explained by the position of southernmost border of studied area within East Asian floristic Region (Takhtadjan 1986).

The Russian Far East area is subdivided into eight floristic provinces (Bakalin 2010), six of which belong to the circumboreal floristic region, while two are within the East Asian region. Although the species distributions within these areas have not been studied exhaustively, some

Table 9. Distribution of Scapania and Macrodiplophyllum Within Floristic Provinces (Based Largely on Bakalin 2010, with Some Corrections)

\begin{tabular}{|c|c|c|c|c|c|c|c|c|c|}
\hline Floristic Provinces & $\begin{array}{l}\frac{\pi}{4} \\
\frac{0}{3} \\
\frac{\pi}{3} \\
0\end{array}$ & 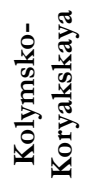 & 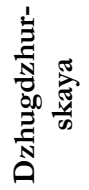 & Z & 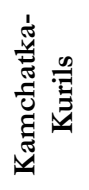 & 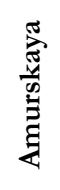 & 息 & 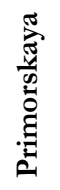 & 番 \\
\hline \multicolumn{10}{|l|}{ Scapania sect. 1. Curtae } \\
\hline S. curta & + & + & & + & + & + & + & & + \\
\hline S. parvifolia & + & + & + & + & + & + & + & + & + \\
\hline S. diplophylloides & & & & & + & & & + & + \\
\hline S. lingulata & & + & & & + & & & + & \\
\hline S. mucronata & + & + & + & & + & + & & + & \\
\hline S. praetervisa & + & & & & + & & & & \\
\hline S. scandica & + & & + & & + & + & + & & \\
\hline S. irrigua & + & + & + & + & + & + & + & + & + \\
\hline S. obcordata & + & + & & & + & & & & \\
\hline S. magadanica & & + & & & & & & & \\
\hline \multicolumn{10}{|l|}{ Sect. 2. Stephania } \\
\hline S. hirosakiensis & & & & & & & & & + \\
\hline S. parvidens & & & & & & & & & + \\
\hline S. parvitexta & & & & & & & & + & \\
\hline \multicolumn{10}{|l|}{ Sect. 3. Kaalaasia } \\
\hline S. gymnostomophilla & + & + & & + & + & & & & \\
\hline S. ligulifolia & + & & & & & & & & \\
\hline \multicolumn{10}{|l|}{ Sect. 4. Scapaniella } \\
\hline S. glaucocephala & & & & & + & & & & \\
\hline S. zemliae & + & & & & & & & & \\
\hline \multicolumn{10}{|l|}{ Sect 5. Apiculatae } \\
\hline S. apiculata & & + & + & + & & + & & + & \\
\hline S. brevicaulis & + & & & & + & & & & \\
\hline S. carinthiaca & & & + & & & + & & + & \\
\hline \multicolumn{10}{|l|}{ Sect. 6. Hyperborea } \\
\hline S. hyperborea & + & + & & + & + & & & & \\
\hline S. degenii & & + & & & + & & & & \\
\hline S. tundrae & + & + & & & + & & & & \\
\hline S. paludicola & + & + & + & + & + & + & + & & + \\
\hline \multicolumn{10}{|l|}{ Sect. 7. Compactae } \\
\hline S. kaurinii & + & & & + & + & & & & \\
\hline \multicolumn{10}{|l|}{ Sect. 8. Cuspiduligerae } \\
\hline S. cuspiduligera & + & + & & + & + & & & & \\
\hline \multicolumn{10}{|l|}{ Sect. 9. Umbrosae } \\
\hline S. umbrosa & & & & & + & & + & & + \\
\hline \multicolumn{10}{|l|}{ Sect. 10. Undulatae } \\
\hline S. undulata & + & + & + & + & + & + & + & + & + \\
\hline S. subalpina & + & + & + & + & + & + & & + & + \\
\hline S. obscura & & + & & & + & & & & \\
\hline S. uliginosa & + & & & & + & & & & \\
\hline S. paludosa & + & + & & + & + & & + & & + \\
\hline S. rufidula & + & & & & & + & & & \\
\hline S. spitsbergensis & + & + & & & & & & & \\
\hline \multicolumn{10}{|l|}{ Sect. 11. Nemorosae } \\
\hline S. crassiretis & + & + & & + & & & & + & + \\
\hline \multicolumn{10}{|l|}{ Sect. 12. Aequilobae } \\
\hline S. sphaerifera & & + & & + & + & & & + & \\
\hline S. ciliata & & & & & & & & + & \\
\hline S. simmonsii & + & + & & & & & & & \\
\hline \multicolumn{10}{|l|}{ Macrodiplophyllum } \\
\hline M. imbricatum & & & & & + & & & & \\
\hline M. microdontum & + & + & + & + & + & + & & + & \\
\hline M. plicatum & + & + & + & + & + & + & + & + & + \\
\hline TOTAL number of species & 26 & 24 & 11 & 16 & 27 & 13 & 9 & 15 & 13 \\
\hline
\end{tabular}


patterns appear to be reliable (Table 9). Scapania and Macrodiplophyllum are the most taxonomically diverse in the Chukotka, Kolymsko-Koryakskaya, and Kamchatka-Kurils provinces (26, 24, and 27 species, respectively). The scapanioid groups in the provinces placed southward, as North-Sakhalin, Amurskaya, South Sakhalin, Primorskaya, and South-Kurils (16, 13, 9, 15, and 13 species, respectively) are logically less rich. The recognized low level of diversity in Dzhudzhurskaya province (11 species) can only be explained by a lack of sufficient data.

Fourteen species were recorded in nearly all provinces of the examined area. Among these, obligate epixylous Scapania apiculata is expectedly absent in Chukotka but inexplicably absent in Kamchatka and the Kurils, despite being present on the adjacent mainland. This may be explained by the pronounced geographic isolation of the islands and the peninsula together with particularly destructive volcanic activity in the area.

The most of Scapania and Macrodiplophyllum species are confined to the northern half of the Russian Far East. 18 species are distributed northward of $58^{\circ} \mathrm{N}$ only, with the noticeable isolated occurrences of $S$. sphaerifera and $S$. rufidula in south of Primorsky Territory and $S$. kaurinii in central Sakhalin Island. We suppose that these local species may be regarded as relicts of Pleistocene glaciations. Among the northerly taxa, two species (S. obscura and M. imbricatum) show eastern tendencies in distribution.

Apparently the distribution of five taxa is characteristic for the extreme eastern regions of the Russian Far East, among which two have southern tendencies in their distributions ( $S$. birosakiensis and $S$. parvidens), while two have northern (S. obscura and M. imbricatum) ones. The remaining taxon ( $S$. diplophylloides) does not exhibit specific latitudinal preferences, but its distribution characteristics are not fully understood due to a lack of investigations in Chukotka.

The southern contacts of the flora are mainly showed by presence of East Asian section Stephania in the Russian Far East. The latter section includes there three species: Scapania parvitexta, which is confined to the southern flank of the Primorsky Territory, and S. birosakiensis and S. parvidens, which are limited to the South Kurils. Additionally, one species of Scapania section Aequilobae ( $S$. ciliata) is restricted to a single occurrence in the area adjacent to the Korean Peninsula. Also two species ( $S$. umbrosa and $S$. carinthiaca) are predominantly located within southern part of the boreal zone and appear to reflect the presence of dark coniferous forests within the studied area.

\section{CONCLUSIONS}

Scapania and Macrodiplophyllum are represented in the Russian Far East by 38 (placed into 12 sections) and three species, respectively. Most of the species have northern holarctic circumpolar distribution and occur in arctic-alpine belt in mountainous areas. The specific trait of Scapania and Macrodiplophyllum complex here is the presence of a limited number of unique East Asian taxa. The occurrence of one taxon (Scapania glaucocephala) can be regarded as a relict, and, probably the species was present here from the time when
Arcto-Tertiary flora in the central region of Kamchatka Peninsula was widely distributed. Three taxa are found in highly isolated southern locations in the southernmost of their specific ranges (S. sphaerifera, S. rufidula, S. kaurinii). These occurrences can be regarded as relicts of Pleistocene glaciations.

The taxonomic diversity of Scapania and Macrodiplophyllum in the Russian Far East appears to be known, although some species may still be added; however, the distribution patterns, especially those at higher altitudes, are poorly understood.

\section{ACKNOWLEDGEMENTS}

We are grateful to Dr. N. A. Konstantinova for her kind permission to duplicate some specimens from KPABG and for loan of some rare taxa. We are deeply obliged to Dr. V. Yu. Barkalov (VLA), and Ms. E. V. Malashkina (VBGI) for collaboration during field works and to Mr. M.A. Bakalin for preparation of figures. The work of V. A. Bakalin was supported by Russian Foundation for Basic Researches (grants 10-04-00050, 10-04-91150, 12-04-91150-ГФЕН). The work of B.-Y. Sun was supported by the grant "Survey of Korean Indigenous Species" from the National Institute of Biological Resources of Ministry of Environment in Korea.

\section{LITERATURE CITED}

Amakawa, T. \& S. Hattori 1953. A revision of the Japanese species of Scapaniaceae I. Journal of the Hattori Botanical Laboratory 9:45-62.

Amakawa, T. \& S. Hattori 1954. A revision of the Japanese species of Scapaniaceae II. Journal of the Hattori Botanical Laboratory 12:91-112.

Amakawa, T. \& S. Hattori 1955. A revision of the Japanese species of Scapaniaceae III. Journal of the Hattori Botanical Laboratory 14:71-90.

Bakalin, V. A. 2004. Macrodiplophyllum imbricatum (Scapaniaceae, Hepaticae), a new species to the flora of Russia. Botanicheskij Zhurnal 89(6):1016-1020 (in Russian) [Бакалин В.А. 2004. Macrodiplophyllum imbricatum (Scapaniaceae, Hepaticae) - новый виА Аля фморы России//Ботанический журнал. Т. 89, № 6. С. 1016-1020.]

Bakalin, V. A. 2009. Flora and phytogeography of hepatics of Kamchatka and adjacent islands. KMK, Moscow, 365 pp. (in Russian) [Бакалин В.А. 2009. ФАора и фитогеография печеночников Камчатки и прилегающих островов. М.: Товарищество научных изАательств КМК. 365 с.]

Bakalin, V. A. 2010. The distribution of bryophytes in the Russian Far East. Part. 1. Hepatics. Izdatel'stvo Dal'nevostochnogo Federal'nogo Universiteta, Vladivostok, 175 pp. (in Russian and English) [Бакалин В.А. 2010. Распространение мохообразных на Аальнем Востоке России. Часть 1. Печеночники. ВАадивосток: Издательство Аальневосточного Федерального университета, 175 с.]

Bakalin, V. A., V. Ya. Cherdantseva, M. S. Ignatov, E. A. Ignatova \& T. I. Nyushko 2009. Bryophyte flora of the South Kuril Islands. Arctoa 18:69-114.

Buch, H. 1928. Die Scapanien Nordeuropas und Sibiriens 2. Systematischer Teil. Societas Scientiarum Fennica, Comm. Biol. 3(1):1-177.

Crandall-Stotler, B., R.E. Stotler \& D. G. Long 2009. Phylogeny and classification of the Marchantiophyta. Edinburgh Journal of Botany 66:155-198.

Hong, W. S. 2003. The Hepaticae and Anthocerotae of the Korean Peninsula: identification keys to the taxa. Lindbergia 28:134-147.

Heinrichs, J., A. Bombosch, K. Feldberg, H.-P. Kreier, J. Hentschel, 
J. Eckstein, D. Long, R.-L. Zhu, A. Schäfer-Verwimp, A. R. Schmidt, B. Shaw, A. J. Shaw \& J. Váňa 2012. A phylogeny of the northern temperate leafy liverwort genus Scapania (Scapaniaceae, Jungermanniales). Molecular Phylogenetics and Evolution 62:973-985.

Horikawa, Y. 1934. Monographia hepaticarum Australi-Japonicarum. Journal of Science of the Hiroshima University., Ser. B, Div. 2, 2:102-316.

Kharkevich, S. S. 1984. The origin and composition of vascular plant flora of Kamchatka. In: L. I. Malyshev (ed.) Istoriya rastitel'nogo pokrova Severnoi Azii. Nauka, Novosibirsk, pp. 107-117 (in Russian) [Харкевич C.C. 1984. ПроисхожАение и состав флоры сосудистых растений Камчатки // История растительного покрова Северной Азии / под. реА. А.И. МаАышева. Новосибирск: Наука. С. 107-117.]

Konstantinova, N. A., V. A. Bakalin, E. N. Andrejeva, A. G. Bezgodov, E. A. Borovichev, M. V. Dulin, Yu. S. Mamontov 2009. Checklist of liverworts (Marchantiophyta) of Russia. Arctoa 18:1-64.

Müller, K. 1905. Monographie der Lebermoosgattung Scapania Dum. Nova Acta Academiae Caesareae Leopoldino-Carolinae 83:1312.

Müller, K. 1944. Beitrage zur Systematik der Lebermoose. IV. Studien zur Kenntnis der Gattung Scapania Dum. Hedwigia 81:238282.

Müller, K. 1955. Lebermoose aus Sudamerika. Feddes Repertorium 58:59-74.

Piippo, S. 1990. Annotated catalogue of Chinese Hepaticae and Anthocerotae. Journal of the Hattori Botanical Laboratory 68:1-192.

Potemkin, A. D. 1998. On the origin, evolution and classification of the genus Scapania (Dum.) Dum. (Hepaticae). Journal of the Hattori Botanical Laboratory 85:33-61.

Potemkin, A. D. 1999. Circumscription of the family Scapaniaceae, with segregation of the new family Diplophyllaceae (Hepaticae). Annales Botanici Fennici 36:271-283.

Potemkin, A. D. 2000. Bryophyte flora of Hunan Province, China. 2. Scapania koponenii sp. nova (Scapaniaceae, Hepaticae). Annales Botanici Fennici 37:41-44.

Potemkin, A. D. 2001. Evolution, phylogeny and classification of Scapaniaceae family (Hepaticae). Doctoral dissertation. Saint-Petersburg, 338 pp. (in Russian) [Потемкин А.А. 2001. Эволюция, фи- могения, классификация семейства Scapaniaceae (Hepaticae). Аиссертация на соискание ученой степени доктора биологических наук. Санкт-Петербург. 338 с.]

Potemkin, A. D. 2002. Phylogenetic system and classification of the family Scapaniaceae Mig. emend. Potemkin (Hepaticae). Annales Botanici Fennici 39:309-334.

Schljakov, R. N. 1981. Hepatics of the North USSR. Vol. 4. Nauka, Leningrad. 220 pp. (in Russian) ШАяков P.Н. 1981. Печеночные мхи Севера СССР. А.: Наука. Т. 4. 220 с.].

Schuster, R. M. 1974. The Hepaticae and Anthocerotae of North America. Vol. 3. Columbia University Press, New York \& London, 880 pp.

Schuster R. M. 1951. Notes on Nearctic Hepaticae. IV. Scapania spitsbergensis and Scapania convexula in North America. The Bryologist 54: 162-180.

Stephani, F. 1909-1912. Species Hepaticarum Vol. IV. Georg et Cie, même Maison. Genève et Bâle, Lyon, 824 pp.

Takhtajan, A. L. 1986. Floristic regions of the world. University of California Press, Berkeley, $544 \mathrm{pp}$.

Váňa J., Hentschel J., Müller J. \& Heinrichs J. 2012. Taxonomic novelties in Scapania. Phytokeys 10: 13-17.

Vilnet, A. A., N. A. Konstantinova \& A. V. Troitsky 2010. Molecular insight on phylogeny and systematic of the Lophoziaceae, Scapaniaceae, Gymnomitriaceae and Jungermanniaceae. Arctoa 19:31-50.

Yamada, K. \& D.-M. Choe 1997. A checklist of Hepaticae and Anthocerotae in the Korean peninsula. Journal of the Hattori Botanical Laboratory 81:281-306.

Yamada, K. \& Z. Iwatsuki 2006. Catalog of the hepatics of Japan. Journal of the Hattori Botanical Laboratory 99:1-106.

Zuo, B.-R. \& T. Cao 2007a. Scapania ampliata, a hepatic species new to China. Bulletin of Botanical Research 27:135-138.

Zuo, B.-R., T. Cao, C. Gao \& J. Sun 2007b. Scapania paraphyllia T. Cao, C. Gao, J. Sun \& B.R. Zho, a new species of Hepaticae (Scapaniaceae) from Zhejiang, China. Acta Phytotaxonomica Sinica 45:311-314

Zuo, B.-R., T. Cao \& S.-L. Guo 2007c. Comparison and assessment of three East-Asian species of the genus Scapania (Hepaticae: Scapaniaceae). Acta Phytotaxonomica Sinica 45:742-750. 
